\title{
4. SITE 465: SOUTHERN HESS RISE ${ }^{1}$
}

\author{
Shipboard Scientific Party²
}

\section{HOLE 465}

Date occupied: 23 August 1978

Date departed: 24 August 1978

Time on hole: 20.75 hours

Position (latitude; longitude): $33^{\circ} 49.23^{\prime} \mathrm{N}$; $178^{\circ} 55.14^{\prime} \mathrm{E}$

Water depth (corrected m, echo sounding): 2161

Bottom felt (m, drill pipe): 2165.5

Penetration (m): 96

Number of cores: 11

Total length of cored section (m): 96

Total core recovered $(\mathrm{m}): 43.89$

Core recovery ( $\%): 46.0$

Oldest sediment cored:

Depth sub-bottom (m): 96

Nature: Foraminifer nannofossil ooze

Age: Early Maastrichtian

Igneous basement: Not penetrated

\section{HOLE 465A}

Date occupied: 24 August 1978

Date departed: 28 August 1978

Time on hole: 83.2 hours

Position (latitude; longitude): $33^{\circ} 49.23^{\prime} \mathrm{N}$; $178^{\circ} 55.14^{\prime} \mathrm{E}$

Water depth (corrected $\mathrm{m}$, echo sounding): 2161

Bottom felt (m, drill pipe): 2165.5

Penetration (m): 476

Number of cores: 46

Total length of cored section $(\mathrm{m}): 437$

Total core recovered $(\mathrm{m}): 108.5$

Core recovery $(\%): 24.8$

\footnotetext{
1 Initial Reports of the Deep Sea Drilling Project, Volume 62.

2 Tracy L. Vallier (Co-Chief Scientist), U.S. Geological Survey, Menlo Park, California; Jörn Thiede (Co-Chief scientist), Department of Geology, University of Oslo, Blindern, Oslo 3, Norway; Charles Adelseck, Jr., Deep Sea Drilling Project, Scripps Institution of Oceanog. raphy, La Jolla, California; Anne Boersma, Lamont-Doherty Geological Observatory, raphy, La Jolla, California: Anne Boersma, Lamont-Doherty Geological Observatory,
Palisades, New York; Pavel Cepek, Bundesanstalt für Geowissenschaften und Rohstoffe, Hannover, Federal Republic of Germany; Walter E. Dean, U.S. Geological Survey. Denver, Colorado; Naoyuki Fujii, Department of Earth Sciences, Kobe University, Nada, Kobe, Japan: Vladimir 1. Koporulin, Geological Institute, U.S.S.R. Academy of Sciences, Moscow, U.S.S.R.; David K. Rea, Department of Atmospheric and Oceanic Science, University of Michigan, Ann Arbor, Michigan; Constance Sancetta, Lamont-Doherty Geological Observatory, Palisades, New York: William Sayre, Department of Oceanography, University Southampton. Southampton, United Kingd Departivent Sciences, lowa State University of Science and Technology, Ames, lowa); André Schaaf, Institut de Géologie, Strasbourg. France; Ronald R. Schmidt, Institute of Earth Sciences, University of Utrecht, Utrecht, The Netherlands; Karl E. Seifert, Department of Earth Sciences, lowa State University of Science and Technology. Ames, lowa; Edith Vincent. Geological Research Division, Scripps Institution of Oceanography, La Jolla, California: Kenneth E. Windom, Department of Earth Sciences, lowa State University of Science and Technology, Ames, lowa.
}

Oldest sediment cored:

Depth sub-bottom (m): 411.7

Nature: Limestone

Age: Late Albian

Measured velocity: $2.89 \mathrm{~km} / \mathrm{s}$

Igneous basement:

Depth sub-bottom $(\mathrm{m}): 411.7$

Nature: Altered trachyte

Velocity range $(\mathrm{km} / \mathrm{s}): 3.60 \pm 0.12$

Principal results: We drilled at Site $\mathbf{4 6 5}$ (Fig. 1) on southern Hess Rise to determine the age of igneous basement, the ages and depositional environments of the sediments, and the paleoenvironmental implications. Southern Hess Rise has been above the local CCD since its formation. This large aseismic structure apparently formed south of the mid-Cretaceous equator and moved northward on the Pacific Plate as it subsided. Two holes (Holes 465 and 465A) were drilled. Hole 465 was cored to a sub-bottom depth of 96 meters. The entire sediment sequence and 64 meters of the volcanic basement (Fig. 2) were continuously cored in Hole 465A to a sub-bottom depth of 476 meters.

In Hole 465,11 cores of nannofossil ooze and foraminifer nannofossil ooze range in age from early Maastrichtian to early Pleistocene. A hiatus of almost 50 m.y. occurs between upper Paleocene and lower Pliocene sediments, but there appears to be a continuous record across the Cretaceous/Tertiary boundary. Chert is a common constituent, and pyrite is present in trace amounts. Hole 465 was abandoned because the ship drifted off the beacon, making it necessary to pull the drill string above the mud line.

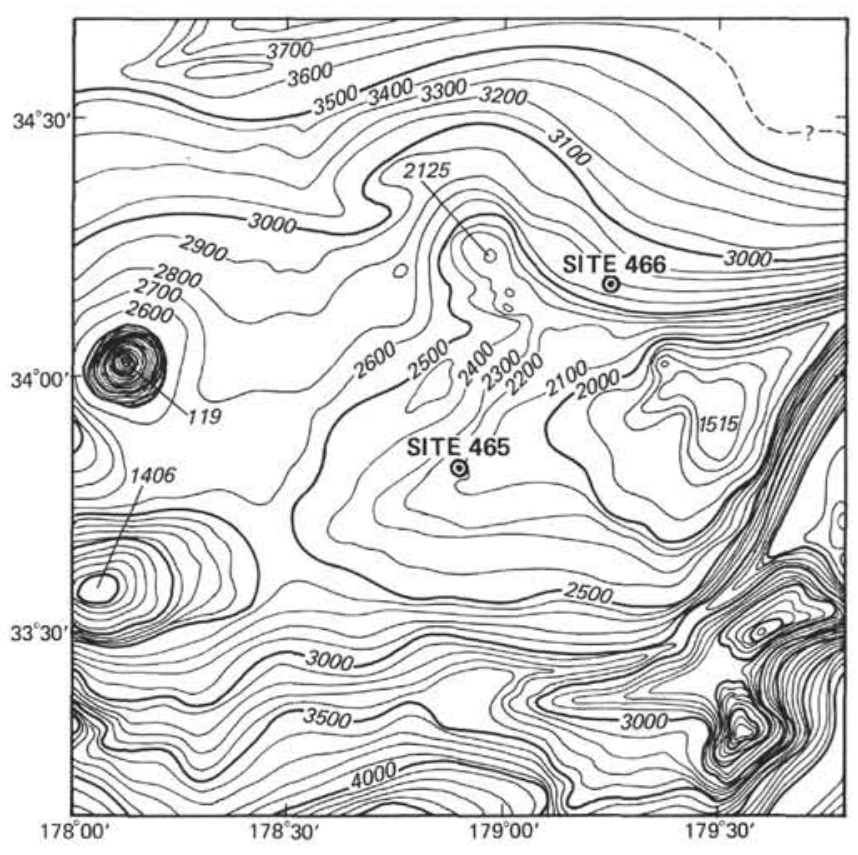

Figure 1. Location of DSDP Sites 465 and 466, southern Hess Rise. Bathymetry from Chase et al. (this volume). 
Hole $465 \mathrm{~A}$ was spudded in to 39 meters, and coring was continuous from that depth to the base of the hole. The Albian to Pleistocene sediments reflect the transition of the southern Hess Rise depositional paleoenvironment from tropical to temperate latitudes-because of horizontal movement of the Pacific Plate-and from shallow to intermediate water depth, because of subsidence of this aseismic rise. The trachyte (Unit III) is highly altered and has some vesicles greater than $5 \mathrm{~mm}$ in diameter, suggesting shallow water, or possibly even subaerial extrusion. Textures show flow orientation of feldspar laths and microlites. Oldest sediments (Unit II) consist of olive-gray, laminated upper Albian to Cenomanian limestone, in a unit 136 meters thick, which shows many indications of current activity and redeposition along the former sea floor. High organic-carbon contents indicate anoxic conditions, probably related to a mid-water oxygen-minimum zone along the submarine slopes of an archipelago. The overlying sediment (Unit I) is 276 meters thick and consists of Coniacian to Pleistocene nannofossil ooze and foraminifer nannofossil ooze, with intercalated chert. This unit reflects a slowly deepening, relatively quiet depositional environment within an intermediate-depth

SITE 465

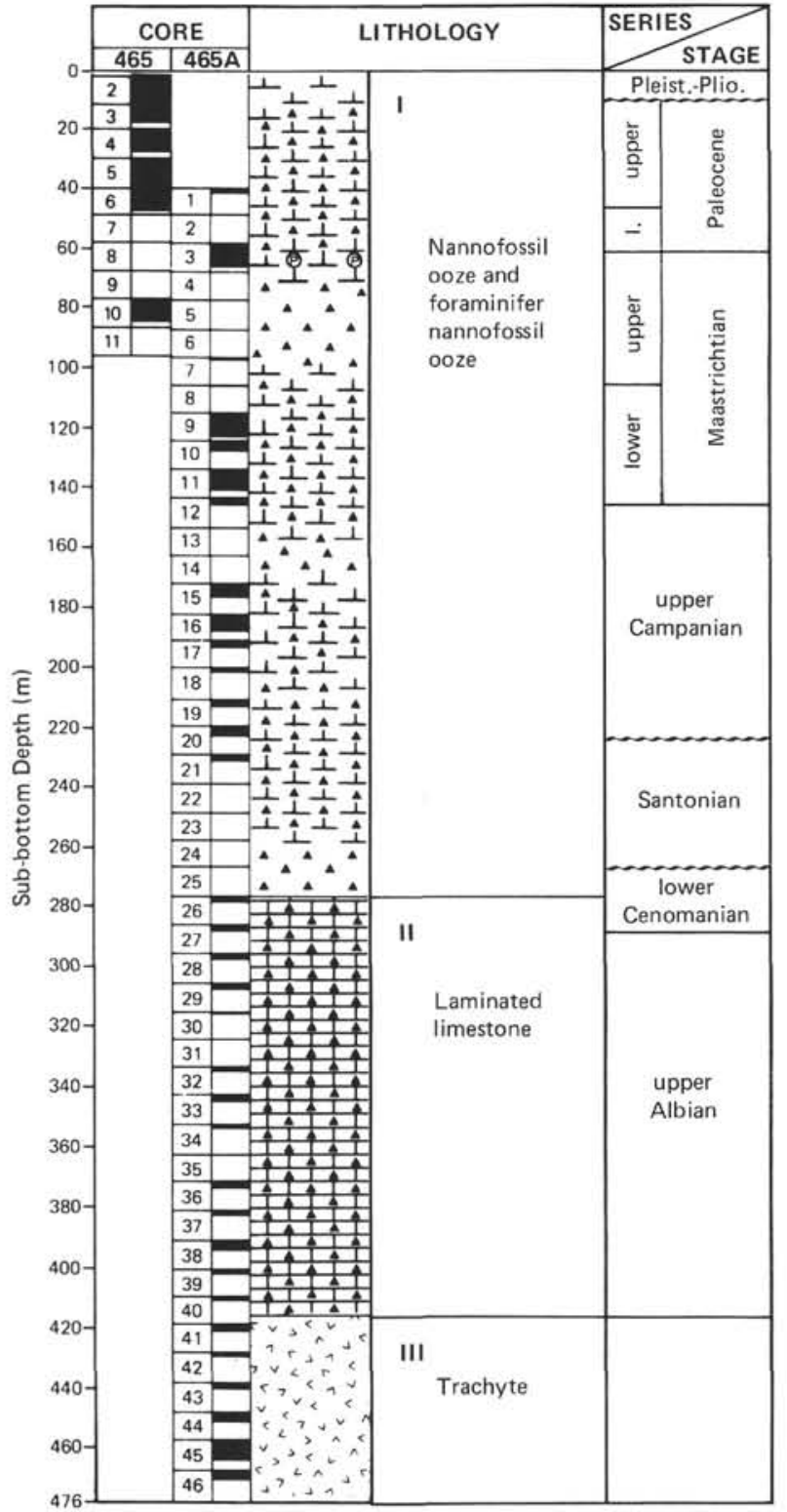

Figure 2. Stratigraphy of Site 465. water mass. Significant hiatuses occur from early Cenomanian to late Coniacian, from Santonian to late Campanian, and from late Paleocene to Pliocene. Calcareous oozes of Lithologic Unit I show signs of intense dissolution, despite their shallow-water depth of deposition. A highlight of this hole was the recovery of an apparently complete sedimentary sequence across the Cretaceous/ Tertiary boundary, with well-preserved sediments of the $G$. eugubina Zone in Core 3 of Hole 465A. A heat flow of $1.36 \mathrm{HFU}$ is similar to that of averaged North Pacific heat flow for crust of this age.

\section{BACKGROUND AND OBJECTIVES}

Hess Rise is one of the major structural features of the central North Pacific. It is bounded on the west by the moat that lies east of the Emperor Seamounts, on the northeast by the Emperor Trough, and on the south by the Mendocino Fracture Zone. These three structural lineaments outline a triangular, elevated, aseismic high that lies above abyssal regions of the Pacific Plate which are characterized as normal oceanic crust by Mesozoic linear magnetic anomalies. Previous attempts to drill Hess Rise during DSDP Leg 32 (Larson, Moberly, et al., 1975) failed to reach basement, and the early origin of Hess Rise has remained largely unknown. The oldest sediments cored at Site 310 are of early Cenomanian to late Albian age. Volcanic rocks reached at the bottom of Hole 464 are overlain by sediments of early Albian (or Aptian) age, suggesting a minimum age of northern Hess Rise of approximately 110 m.y. However, age data on the bottom sediment cores from Hole 464 are very poor.

Previous coring on Hess Rise sampled sediments from water depths $>3.5 \mathrm{~km}$ (Site 310 ) and $>4.5 \mathrm{~km}$ (Site 464). Because hiatuses and, at least in part, unfossiliferous pelagic-clay sequences were found at both previous sites, the location of Site 465 (Figs. 3 and 4) had been planned where a well-stratified, 400- to 500-meterthick sedimentary sequence above an apparently volcanic basement could be sampled in relatively shallow water. There are several reasons for the choice of such a location:

1) Southern Hess Rise is close to the northern boundary of modern subtropical planktonic-foraminifer faunas (Vincent, 1975). Well-documented sediment sections from Hess Rise could allow a close correlation between high- and low-latitude biostratigraphies elsewhere in the central Pacific.

2) We expected the shallow water depth to provide us with pelagic sediments containing well-preserved calcareous fossils.

3) The location close to the crest of Hess Rise (Fig. 4)-yet on a gently sloping plateau underlain by a clearly stratified sedimentary sequence-may have been protected from reworking of older sediments, such as that caused by slumping.

4) Because of the recognition of important and longlasting hiatuses in the Cenozoic section penetrated at Sites 310 and 464 , a shallow location might provide us with an optimal chance to avoid a depth level which had been affected by the current regime generating the hiatuses.

5) Common chert layers in the Cretaceous section of Sites 310 and 464 had resulted in a very poor recovery of 


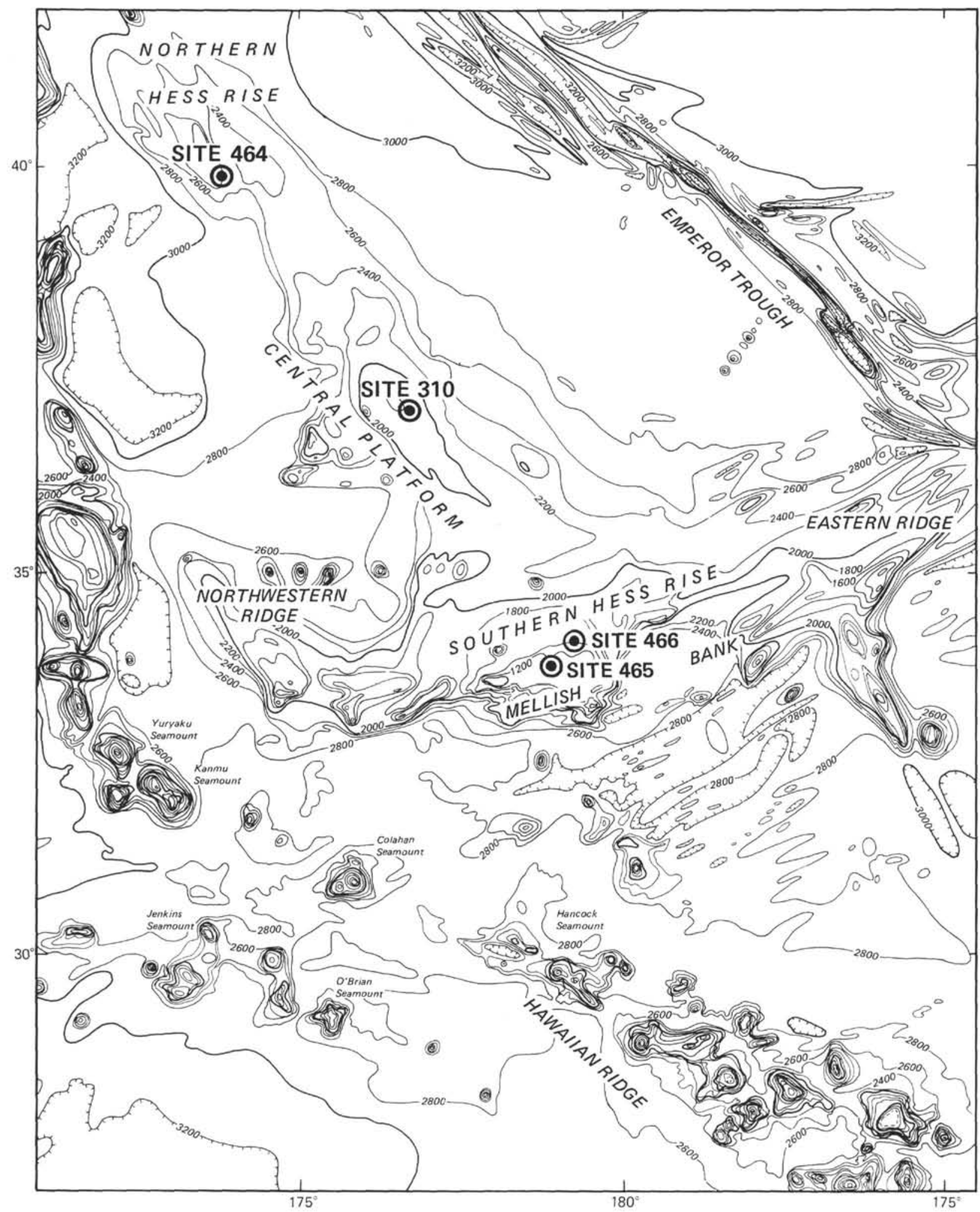

Figure 3. Location map for sites drilled on Hess Rise. Site 310 was drilled during Leg 32 (Larson, Moberly, et al., 1975). Bathymetry in fathoms (from Chase et al., 1971). 


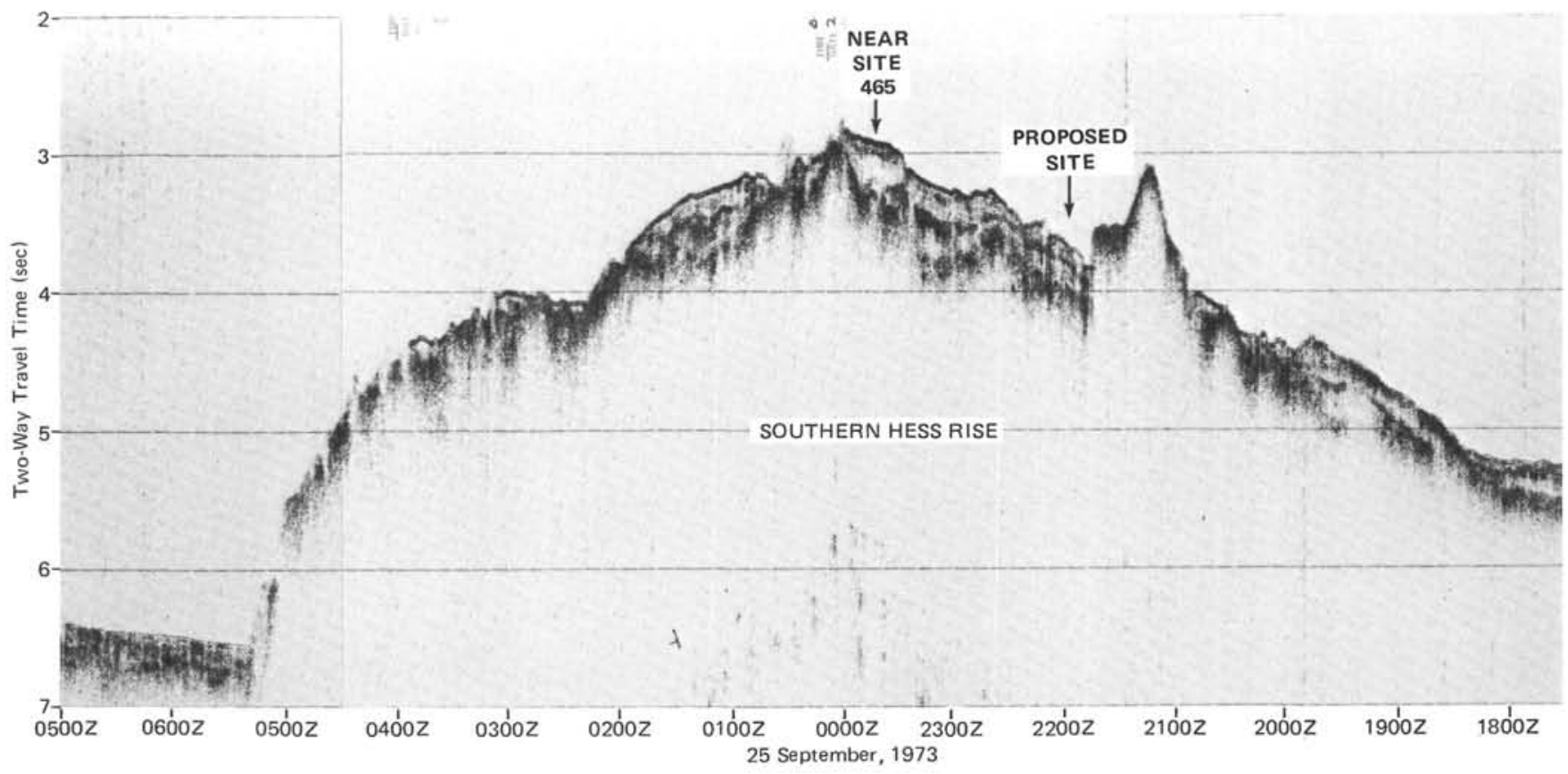

Figure 4. Glomar Challenger Leg 32 track line (Larson et al., 1975) across southern Hess Rise. Speed was about 10.5 knots, and course almost $150^{\circ}$, from right to left.

the relatively soft chalks, claystones, marlstones, and limestones. Both of the previously sampled sections are therefore of limited value in reconstruction of the late Mesozoic central Pacific paleoenvironment. By selecting a shallow site, we hoped to avoid lithofacies rich in silica and therefore unaffected by chert formation.

6) Although none of the previously drilled sites on Hess Rise had revealed evidence for a shallow-water depositional environment during its early history, we hoped to penetrate reef deposits or other shallow-water sediments before reaching volcanic basement rocks.

7) We hoped that the location close to the rise crest and the pinnacle-shaped configuration of the acoustic basement would allow us not only to reach rocks of the supposed volcanic edifice under the sediment cover of Hess Rise, but also to penetrate any igneous basement rocks to considerable depth.

We expected that, because of the continuous northward horizontal movement of the Pacific Plate from a position well south of the equator during mid-Cretaceous time to its present location under the oligotrophic subtropical central North Pacific water masses (Lancelot and Larson, 1975), the sediments on southern Hess Rise would show large variations in composition, as well as in thickness, despite the shallow water depth. Moreover, by combining the results of Site 310 on central Hess Rise, 464 on northern Hess Rise, and 465 on southern Hess Rise, we planned to recover Upper Cretaceous sedimentary sequences that could document the time when this region crossed under the fertile equatorial surface-current regime. Expanded stratigraphic sequences caused by high biogenic-sedimentation rates were expected to provide an opportunity to study the timing of the evolution of the mid- and Late Cretaceous calcareous and siliceous planktonic communities. The three sites on Hess Rise are spread over a depth range of approximately $3 \mathrm{~km}$, which could provide us with clues to the position of the late Mesozoic CCD.

A position for Site 465 on southern Hess Rise which seemed suitable to achieve the above-listed goals had been selected along the Glomar Challenger Leg 32 seismic-reflection profile across southern Hess Rise (Fig. 4) (Larson, Moberly, et al., 1975).

\section{OPERATIONS}

We completed a short seismic-reflection survey of Site 464 and steamed toward Site 465 on southern Hess Rise, where a drill site had been chosen on the Glomar Challenger Leg 32 air-gun profile. About 50 miles from the proposed site, we intersected the Glomar Challenger Leg 32 track line $(1700 Z, 24$ September 1973) and steamed along that profile to the site. We did not drop a beacon on the proposed site (Fig. 4), but continued another 15 miles along the GL32 profile to a more promising location. At $2045 \mathrm{Z}$ on 23 August, we dropped the beacon and continued on course until $2145 \mathrm{Z}$. After pulling in the gear, we returned to the beacon (Fig. 5).

Site 465 is located in 2161 meters (corrected from PDR) of water. This depth was chosen, rather than the length of drill pipe, because of some difficulty in establishing the mud line. Several reflectors are apparent on the air-gun seismic-reflection profile across the site (Fig. 6 ). Hole 465 was spudded in, and the first core was on deck at $0715 \mathrm{Z}$, August 24. After 11 cores had been cut to a depth of 96 meters, the ship drifted off the beacon, and the drill string was pulled above the mud line at $1800 \mathrm{Z}$. We repositioned over the beacon until 1955Z, when a second hole (Hole 465A) was spudded in, drilled to a depth of 39 meters, and subsequently cored contin- 


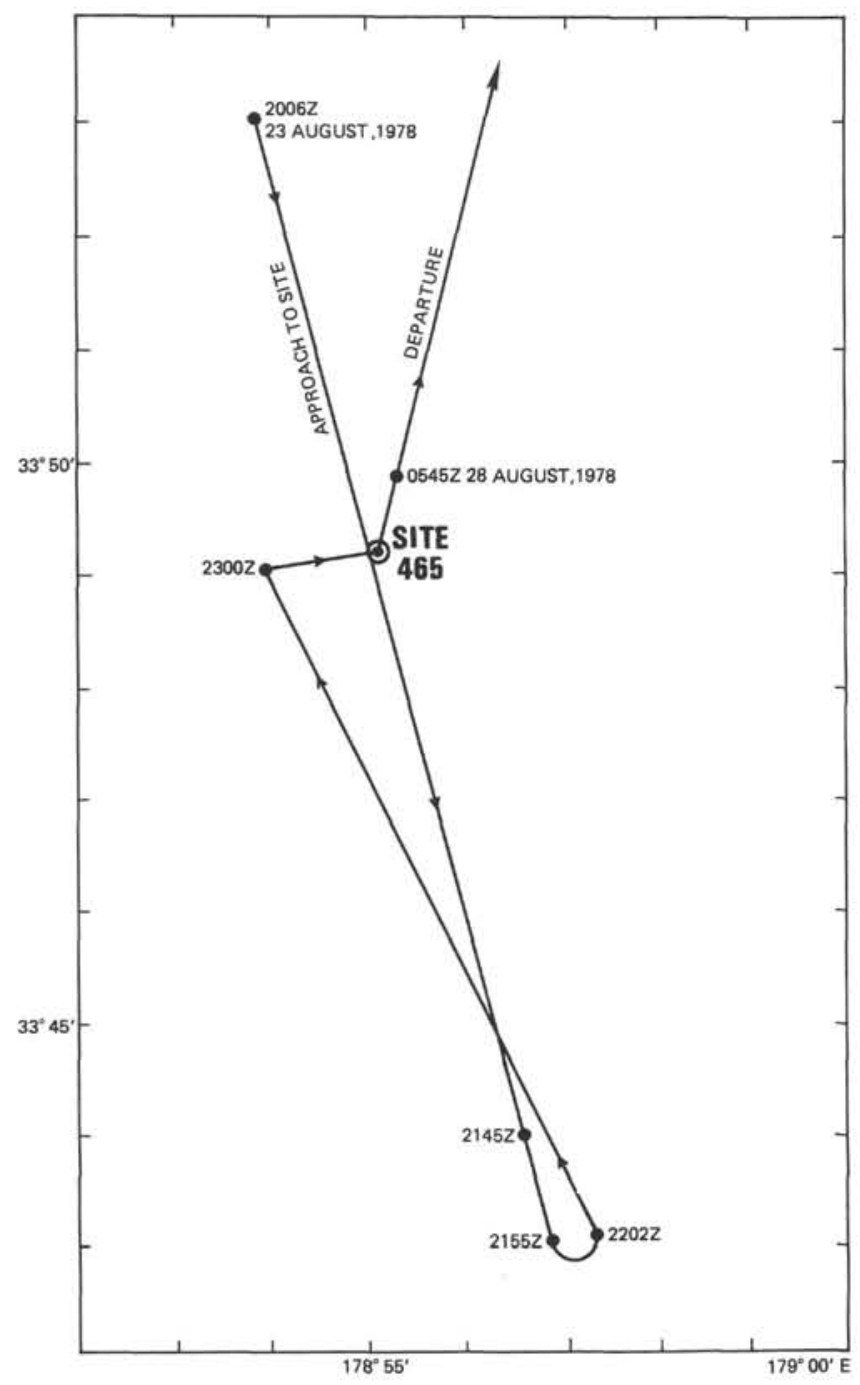

Figure 5. Glomar Challenger Leg 62 track lines for approach to and departure from Site 465 . uously to a sub-bottom depth of 476 meters (Table 1). We began coring at 39 meters in Hole $465 \mathrm{~A}$, well above the base of Hole 465, in order to sample the Cretaceous/ Tertiary boundary, which had not been sampled adequately in Hole 465.

A hole-inclination test was made as we took Core 40 , which indicated that the hole was inclined about $4^{\circ}$ from the vertical. Heat-flow measurements were attempted between Cores 10 and 11 in Hole 465, and between Cores 6 and 7, 8 and 9, and 14 and 15 in Hole 465A.

The bit reached igneous basement at 411.7 meters in Core 40 . Coring was continued in the basement to a depth of 476 meters (Core 46). When the core barrel was dropped for Core 47, the drill string had become stuck (August 27, 1300Z), and we were unable to circulate or to loosen the string. An attempt was made to shoot off the bottom-hole assembly, but the explosive charge fortunately failed to detonate. Subsequently, while raising the drill string a small amount, it was apparent that the drill string somehow had loosened. Thereafter, we pulled out the drill string with no further problems.

Site 465 was abandoned at $0512 \mathrm{Z}$ on August 28, and we departed for Site 466 (Fig. 5). Gear was streamed by $0530 Z$, and we were under way for Site 466 .

\section{LITHOLOGIC SUMMARY}

\section{Lithologic Subdivision}

The section recovered at Site 465 on southern Hess Rise was subdivided into three lithologic units, on the basis of composition, degree of lithification, and sedimentary structures (Table 2; Fig. 2).

\section{Unit I: Nannofossil Ooze and Foraminifer Nannofossil Ooze (0-276 m)}

Unit I consists of homogeneous, white (N9 and lighter), moderately to highly disturbed nannofossil ooze. The main variability within the unit is in the rela-

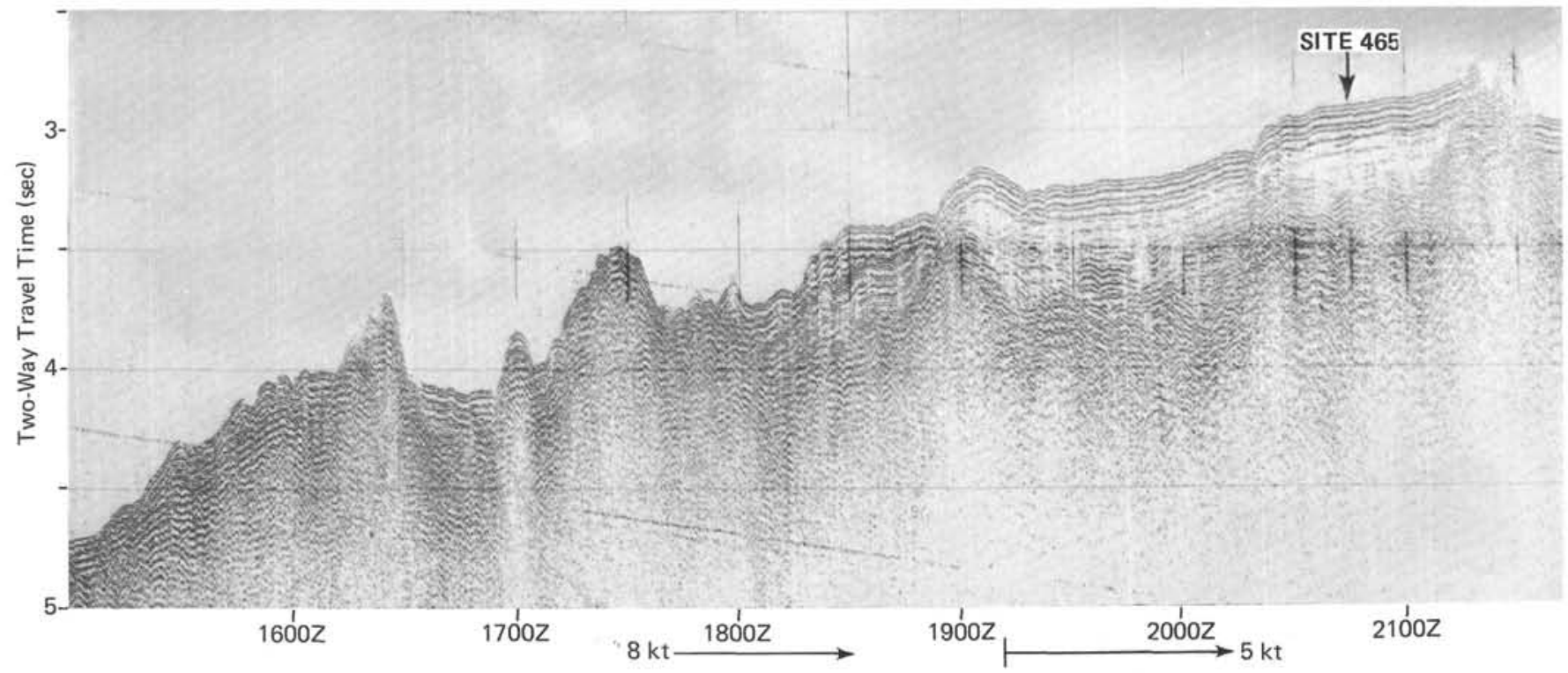

Figure 6. Glomar Challenger Leg 62 air-gun seismic-reflection profile approaching Site 465, 23 August 1978. 
Table 1. Site 465 coring summary.

\begin{tabular}{|c|c|c|c|c|c|c|c|}
\hline $\begin{array}{l}\text { Core } \\
\text { No. }\end{array}$ & $\begin{array}{c}\text { Date } \\
\text { (August } \\
\text { 1978) }\end{array}$ & $\begin{array}{l}\text { Time } \\
\text { (L) }\end{array}$ & $\begin{array}{l}\text { Depth From } \\
\text { Drill Floor } \\
\text { (m) } \\
\text { Top Bottom }\end{array}$ & $\begin{array}{l}\text { Depth Below } \\
\text { Sea Floor } \\
\text { (m) } \\
\text { Top Bottom }\end{array}$ & $\begin{array}{l}\text { Length } \\
\text { Cored } \\
\text { (m) }\end{array}$ & $\begin{array}{l}\text { Length } \\
\text { Recovered } \\
\text { (m) }\end{array}$ & $\begin{array}{l}\text { Percent } \\
\text { Recovery }\end{array}$ \\
\hline $465-1$ & 24 & 1915 & $2165.5-2166.5$ & $0.0-1.0$ & 1.0 & 0.89 & 89 \\
\hline 2 & 24 & 1956 & $2166.5-2176.0$ & $1.0-10.5$ & 9.5 & 8.31 & 87.5 \\
\hline 3 & 24 & 2036 & $2176.0-2185.5$ & $10.5-20.0$ & 9.5 & 5.98 & 62.9 \\
\hline 4 & 24 & 2127 & $2185.5-2195.0$ & $20.0-29.5$ & 9.5 & 5.56 & 58.5 \\
\hline 5 & 24 & 2218 & $2195.0-2204.5$ & $29.5-39.0$ & 9.5 & 8.57 & 90.2 \\
\hline 6 & 24 & 2257 & $2204.5-2214.0$ & $39.0-48.5$ & 9.5 & 6.96 & 73.3 \\
\hline 7 & 25 & 0011 & $2214.0-2223.5$ & $48.5-58.0$ & 9.5 & 0.07 & 0.8 \\
\hline 8 & 25 & 0113 & $2223.5-2233.0$ & $58.0-67.5$ & 9.5 & 0.04 & 0.4 \\
\hline 9 & 25 & 0205 & $2233.0-2242.5$ & $67.5-77.0$ & 9.5 & 0.06 & 0.7 \\
\hline 10 & 25 & 0300 & $2242.5-2252.0$ & $77.0-86.5$ & 9.5 & 7.42 & 78.1 \\
\hline 11 & 25 & 0535 & $2252.0-2261.5$ & $86.5-96.0$ & 9.5 & 0.03 & 3.2 \\
\hline $465 \mathrm{~A}-1$ & 25 & 0934 & $2204.5-2214.0$ & $39.0-48.5$ & 9.5 & 1.5 & 15.8 \\
\hline 2 & 25 & 1020 & $2214.0-2223.5$ & $48.5-58.0$ & 9.5 & 0.02 & 0.2 \\
\hline 3 & 25 & 1106 & $2223.5-2233.0$ & $58.0-67.5$ & 9.5 & 8.27 & 87.0 \\
\hline 4 & 25 & 1204 & $2233.0-2242.5$ & $67.5-77.0$ & 9.5 & 0.12 & 1.3 \\
\hline 5 & 25 & 1250 & $2242.5-2252.0$ & $77.0-86.3$ & 9.5 & 0 & 0 \\
\hline 6 & 25 & 1347 & $2252.0-2261.5$ & $86.5-96.0$ & 9.5 & 0.06 & 0.6 \\
\hline 7 & 25 & 1655 & $2261.5-2271.0$ & $96.0-105.5$ & 9.5 & 0.80 & 8.4 \\
\hline 8 & 25 & 1741 & $2271.0-2280.5$ & $105.5-115.0$ & 9.5 & 0.64 & 6.7 \\
\hline 9 & 25 & 2032 & $2280.5-2290.0$ & $115.0-124.5$ & 9.5 & 8.03 & 84.5 \\
\hline 10 & 25 & 2128 & $2290.0-2299.5$ & $124.5-134.0$ & 9.5 & 3.85 & 40.3 \\
\hline 11 & 25 & 2215 & $2299.5-2309.0$ & $134.0-143.5$ & 9.5 & 6.33 & 66.6 \\
\hline 12 & 25 & 2300 & $2309.0-2318.5$ & $143.5-153.0$ & 9.5 & 2.38 & 25.1 \\
\hline 13 & 25 & 2348 & $2318.5-2328.0$ & $153.0-162.5$ & 9.5 & 0.3 & 3.2 \\
\hline 14 & 26 & 0048 & $2328.0-2337.5$ & $162.5-172.0$ & 9.5 & 0.05 & 0.5 \\
\hline 15 & 26 & 0342 & $2337.5-2347.0$ & $172.0-181.5$ & 9.5 & 4.53 & 47.7 \\
\hline 16 & 26 & 0436 & $2347.0-2356.5$ & $181.5-191.0$ & 9.5 & 5.74 & 60.4 \\
\hline 17 & 26 & 0532 & $2356.5-2366.0$ & $191.0-200.5$ & 9.5 & 2.38 & 25.1 \\
\hline 18 & 26 & 0623 & $2366.0-2375.5$ & $200.5-210.0$ & 9.5 & 1.95 & 20.5 \\
\hline 19 & 26 & 0715 & $2375.5-2385.0$ & $210.0-219.5$ & 9.5 & 2.72 & 28.6 \\
\hline 20 & 26 & 0806 & $2385.0-2394.5$ & $219.5-229.0$ & 9.5 & 3.48 & 36.6 \\
\hline 21 & 26 & 0855 & $2394.5-2404.0$ & $229.0-238.5$ & 9.5 & 2.30 & 24.2 \\
\hline 22 & 26 & 0946 & $2404.0-2413.5$ & $238.5-248.0$ & 9.5 & 0.10 & 1.1 \\
\hline 23 & 26 & 1038 & $2413.5-2423.0$ & $248.0-257.5$ & 9.5 & 0.15 & 1.6 \\
\hline 24 & 26 & 1130 & $2423.0-2432.5$ & $257.5-267.0$ & 9.5 & 0.11 & 1.2 \\
\hline 25 & 26 & 1246 & $2432.5-2442.0$ & $267.0-276.5$ & 9.5 & 0.06 & 0.6 \\
\hline 26 & 26 & 1436 & $2442.0-2451.5$ & $276.5-286.0$ & 9.5 & 1.20 & 12.6 \\
\hline 27 & 26 & 1620 & $2451.5-2461.0$ & $286.0-295.5$ & 9.5 & 2.54 & 27.1 \\
\hline 28 & 26 & 1814 & $2461.0-2470.5$ & $295.5-305.0$ & 9.5 & 2.06 & 21.7 \\
\hline 29 & 26 & 1949 & $2470.5-2480.0$ & $305.0-314.5$ & 9.5 & 2.38 & 25.1 \\
\hline 30 & 26 & 2050 & $2480.0-2489.5$ & $314.5-324.0$ & 9.5 & 0.58 & 6.1 \\
\hline 31 & 26 & 2205 & $2489.5-2499.0$ & $324.0-333.5$ & 9.5 & 0.35 & 3.7 \\
\hline 32 & 26 & 2315 & $2499.0-2508.5$ & $333.5-343.0$ & 9.5 & 1.50 & 15.8 \\
\hline 33 & 27 & 0031 & $2508.5-2518.0$ & $343.0-352.5$ & 9.5 & 2.99 & 31.5 \\
\hline 34 & 27 & 0149 & $2518.0-2527.5$ & $352.5-362.0$ & 9.5 & 2.15 & 22.6 \\
\hline 35 & 27 & 0336 & $2527.5-2537.0$ & $362.0-271.5$ & 9.5 & 0.59 & 6.2 \\
\hline 36 & 27 & 0457 & $2537.0-2546.5$ & $371.5-381.0$ & 9.5 & 3.25 & 34.2 \\
\hline 37 & 27 & 0626 & $2546.5-2556.0$ & $381.0-390.5$ & 9.5 & 2.38 & 25.1 \\
\hline 38 & 27 & 0751 & $2556.0-2565.0$ & $390.5-400.0$ & 9.5 & 3.77 & 40.0 \\
\hline 39 & 27 & 0916 & $2565.0-2575.0$ & $400.0-409.5$ & 9.5 & 2.42 & 25.5 \\
\hline 40 & 27 & 1137 & $2575.0-2584.5$ & $409.5-419.0$ & 9.5 & 3.0 & 31.6 \\
\hline 41 & 27 & 1346 & $2584.5-2594.0$ & $419.0-428.5$ & 9.5 & 3.07 & 32.3 \\
\hline 42 & 27 & 1529 & $2594.0-2603.5$ & $428.5-438.0$ & 9.5 & 2.04 & 38.1 \\
\hline 43 & 27 & 1658 & $2603.5-2613.0$ & $438.0-447.5$ & 9.5 & 2.04 & 21.4 \\
\hline 44 & 27 & 1854 & $2613.0-2622.5$ & $447.5-457.0$ & 9.5 & 3.45 & 36.6 \\
\hline 45 & 27 & 2250 & $2622.5-2632.0$ & $457.0-466.5$ & 9.5 & 6.0 & 63.2 \\
\hline 46 & 28 & 0044 & $2632.0-2641.5$ & $466.5-476.0$ & 9.5 & 3.29 & 34.6 \\
\hline
\end{tabular}

tive proportions of foraminifers and nannofossils. On the basis of smear-slide descriptions (Appendix A), foraminifers generally constitute less than $30 \%$ of the sediment, and nannofossils more than $50 \%$. Therefore, most sediments in Unit I are classified as nannofossil ooze (foraminifers $<10 \%$ ) or foraminifer nannofossil ooze (foraminifers 10-30\%). Calcareous microfossils are very well preserved throughout Unit I. Clay mineralogy is given in Appendix B (see also Nagel and Schumann, this volume).
The only observed macrofossils were large fragments of Inoceramus, up to $3.5 \mathrm{~cm}$ in length and $1 \mathrm{~cm}$ thick, in Cores 9A and 13A.

Most of the sediment recovered from Unit I is soupy to stiff ooze; sediment firm enough and coherent enough to be called chalk is rare, and was encountered only in Cores 18A and 21A. Undoubtedly, the in situ abundance of chalk is much greater, but, because of high pump pressures required to core chert, much of the chalk was lost.

Chert was first encountered in the core catcher of Core 2, and is a common constituent throughout the unit. With few exceptions, the chert is medium to light gray in color (N4 to N7).

Pyrite occurs as black blebs up to $1 \mathrm{~cm}$ in diameter in Sections 3 and 4 of Core $3 \mathrm{~A}$. Smearing of black pyrite with white ooze during the drilling process imparted a gray color to the sediment in Section 3 of Core 3A. Pyrite also occurs in trace amounts throughout the section (Appendix A). Additional evidence for sulfate reduction within the sediments of Unit I was the odor of $\mathrm{H}_{2} \mathrm{~S}$ from all cores when first opened. Also, chert fragments from Unit I gave off a strong odor when cut.

Crystals and crystal aggregates of carbonate are common in the sediments throughout Unit I. Individual crystals occur as "needles" ( $\sim 2-4 \mu$ m wide and 10-15 $\mu \mathrm{m}$ long), as subangular to subrounded, equant grains $(\sim 10-20 \mu \mathrm{m}$ in diameter), and as a matrix of fine crystals $(<1 \mu \mathrm{m})$.

The boundary between Units I and II is placed at the bottom of Core 25A. Unfortunately, Cores 24A and $25 \mathrm{~A}$ recovered only chert, so that the actual contact between ooze (chalk?) of Unit I and limestone of Unit II was not observed. It is unlikely that any limestone of Unit II occurs above Core 26A (276 m sub-bottom), although some ooze (chalk?) of Unit I may have extended into Core $26 \mathrm{~A}$ and may have been washed out by the high pump pressures that are required to cut the chert and limestone.

\section{Unit II: Laminated Limestone (276-411.7 m)}

The dominant lithology of Unit II is limestone, laminated on a scale of less than $1 \mathrm{~mm}$, and colored various shades of olive-gray (mostly olive-gray, 5 Y $5 / 2$ and $5 \mathrm{Y} \mathrm{4/2}$, with some dark olive-gray, $5 \mathrm{Y} 3 / 2$, and light olive-gray, 5Y 6/2) (Fig. 7). The laminated limestone is pelagic and similar in general petrographic characteristics to the pelagic limestones of Lithologic Units II, III, and IV at Site 463 , in that it consists of silicified radiolarians and foraminifers in a micritic matrix. The

Table 2. Lithologic units at Site 465.

\begin{tabular}{|c|c|c|c|c|c|}
\hline Unit & Lithology & Cores & $\begin{array}{l}\text { Sub-bottom } \\
\text { Depth } \\
\text { (m) }\end{array}$ & $\begin{array}{l}\text { Thickness } \\
\text { (m) }\end{array}$ & $\begin{array}{c}\text { Age } \\
\text { (m.y.) }\end{array}$ \\
\hline I & $\begin{array}{l}\text { Nannofossil ooze and } \\
\text { foraminifer nannofossil oóze }\end{array}$ & $\begin{array}{c}1-11 \\
1 \mathrm{~A}-25 \mathrm{~A}\end{array}$ & $0-276$ & 276 & $\begin{array}{l}\text { Pleistocene to late } \\
\text { Turonian }(0-86 \text { m.y.) }\end{array}$ \\
\hline II & Laminated limestone & $26 \mathrm{~A}-40 \mathrm{~A}$ & $276-411.7$ & 135.7 & $\begin{array}{l}\text { Early Cenomanian to } \\
\text { late Albian }(98-103 \text { m.y.) }\end{array}$ \\
\hline III & Trachyte & $40 \mathrm{~A}-46 \mathrm{~A}$ & $411.7-476.0$ & 64.3 & $\begin{array}{l}\text { Late Albian or older } \\
(103+\text { m.y. })\end{array}$ \\
\hline
\end{tabular}




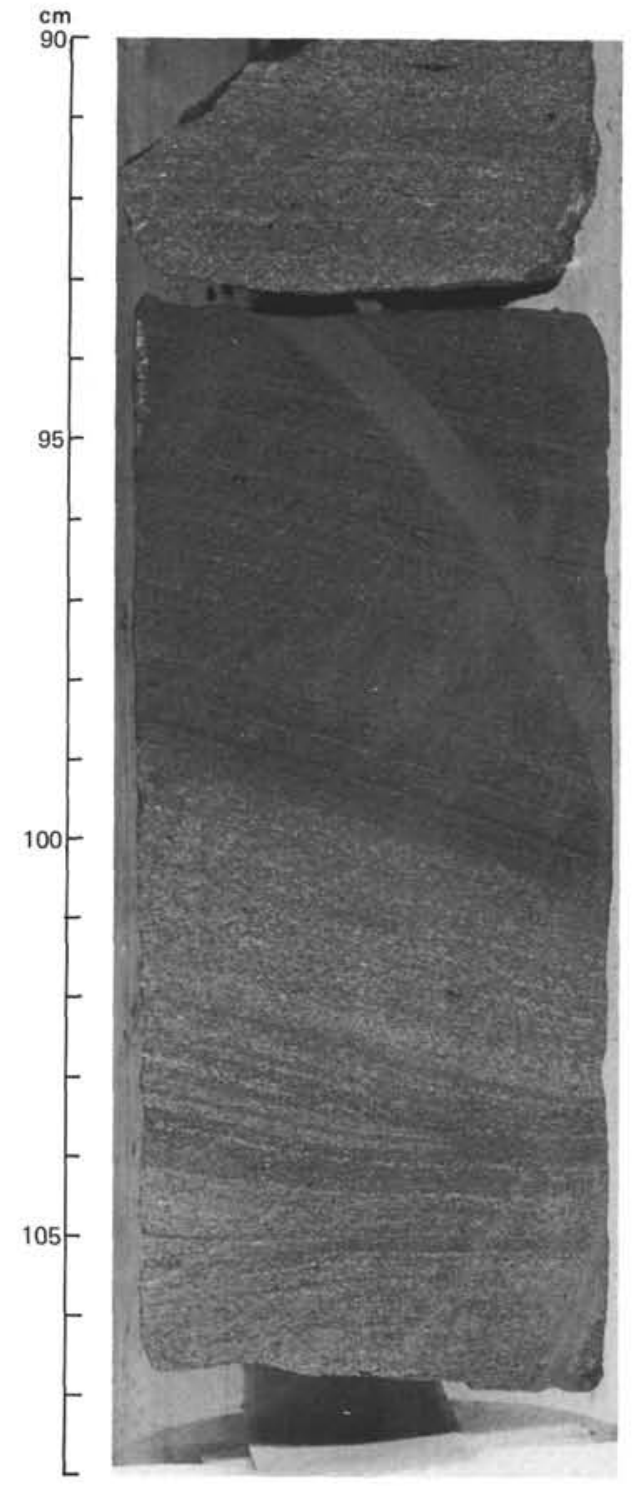

Figure 7. Core photograph of typical laminated olive-gray limestone of Unit II, but with laminae showing a change in dip, 465A-40-1, $90-108 \mathrm{~cm}$.

main differences are the laminated appearance of the limestone at Site 465 and the much greater degree of silicification of the pelagic limestones at Site 463. The laminated appearance of the limestone at Site 465 is mainly the result of wispy, discontinuous, flaser-like laminae of dark (organic?) matter (Fig. 8A, B), differences in the degree of silicification (Fig. 8C), and concentrations of radiolarians and foraminifers into layers (Fig. 8D). The discontinuous laminae are distorted around radiolarians and foraminifers, giving the laminae a lens-shaped or "birds-eye" appearance in thin section (Fig. 8B). The internal structure of radiolarians and walls of foraminifers mostly has been destroyed by silicification, but these features are preserved in some samples.

Thin beds of gray (mostly N4 with some beds of N5 and N6), finely-crystalline limestone commonly occur interbedded with olive-gray limestone throughout the unit. They usually are less than $2 \mathrm{~cm}$ thick (Fig. 9), with a maximum thickness of $22 \mathrm{~cm}$ in Core $29 \mathrm{~A}$, Section 1 , $76-98 \mathrm{~cm}$. About $5 \%$ of the rocks recovered from Unit II are gray limestone, with a maximum of $30 \%$ in Core 29A. The massive gray limestone beds mostly consist of micrite that has been silicified more than the laminated limestone (Fig. 9). The laminated limestone generally contains less than $5 \% \mathrm{SiO}_{2}$, whereas the gray limestone beds generally contain more than $15 \% \mathrm{SiO}_{2}$ (see Dean, this volume). The contact between a gray limestone bed and an underlying laminated olive-gray limestone bed is always sharp. The upper contact of a gray limestone bed is usually gradational with the overlying olive-gray limestone, but may be sharp, and commonly exhibits evidence of scour and erosion (Fig. 10).

The dip of laminae in the olive-gray limestone beds appears to increase with depth in the hole, deviating from the horizontal by as much as $15^{\circ}$. Some of this dip change may be only apparent, caused by deviation of the hole from vertical (an inclination test during collection of Core 40 showed a $4^{\circ}$ deviation from vertical), but most dip is real. Dips of laminae within any one piece of limestone are usually the same, although changes in dip of laminae of about $10^{\circ}$ within a single piece were observed (Fig. 7). Graded bedding was observed only at the top of Unit II. Truncation of ripple(?) lamination by overlying horizontal laminae also was observed in several places within Unit II.

Chert is a common and persistent minor lithology throughout Unit II. The color of the chert varies only slightly and is mostly black (N1 and N2). The chert of Unit II, like the chert of Unit I, gave off a strong sulfur odor when cut. At several places within Unit II, chert encloses a thin bed of what appears to be typical laminated olive-gray limestone; however, thin-sections reveal that the chert has preserved the laminated fabric of the original radiolarian- and organic-carbon-rich sediment, and that the limestone in the center of the chert also has been silicified (Fig. 11). Radiolarians apparently were a common constituent of the original sediment throughout Unit II, but they almost all have been replaced by $\mathrm{CaCO}_{3}$ (Fig. 8B, C). As a result, very few recognizable radiolarians were recovered from Unit II. Veins filled with coarsely crystalline calcite and quartz were observed at a number of places cutting across beds of laminated olive-gray limestone.

The base of Unit II from $110 \mathrm{~cm}$ in Section 1, Core $40 \mathrm{~A}$, to the top of the trachyte (Unit III) at $65 \mathrm{~cm}$ in Section 2 , Core $40 \mathrm{~A}$, exhibits considerable lithologic variation. The first of several beds of massive clastic limestone was observed from 110 to $115 \mathrm{~cm}$ in Section 1, Core 40A. Many of the clasts in the clastic limestone beds are of altered trachyte. The beds of clastic limestone are usually intercalated between beds of olive-gray limestone with abundant organic-carbon-rich laminae.

Volcanic ash was first observed from 143 to $148 \mathrm{~cm}$ in Section 1, Core 40A, where it is intercalated with olivegray limestone, dolomite, organic-rich layers, and pyrite. Beds and laminae of water-laid ash are common in Section 2, Core 40A (Fig. 12). The trachyte of Unit III is overlain immediately by a bed of horizontal and cross 

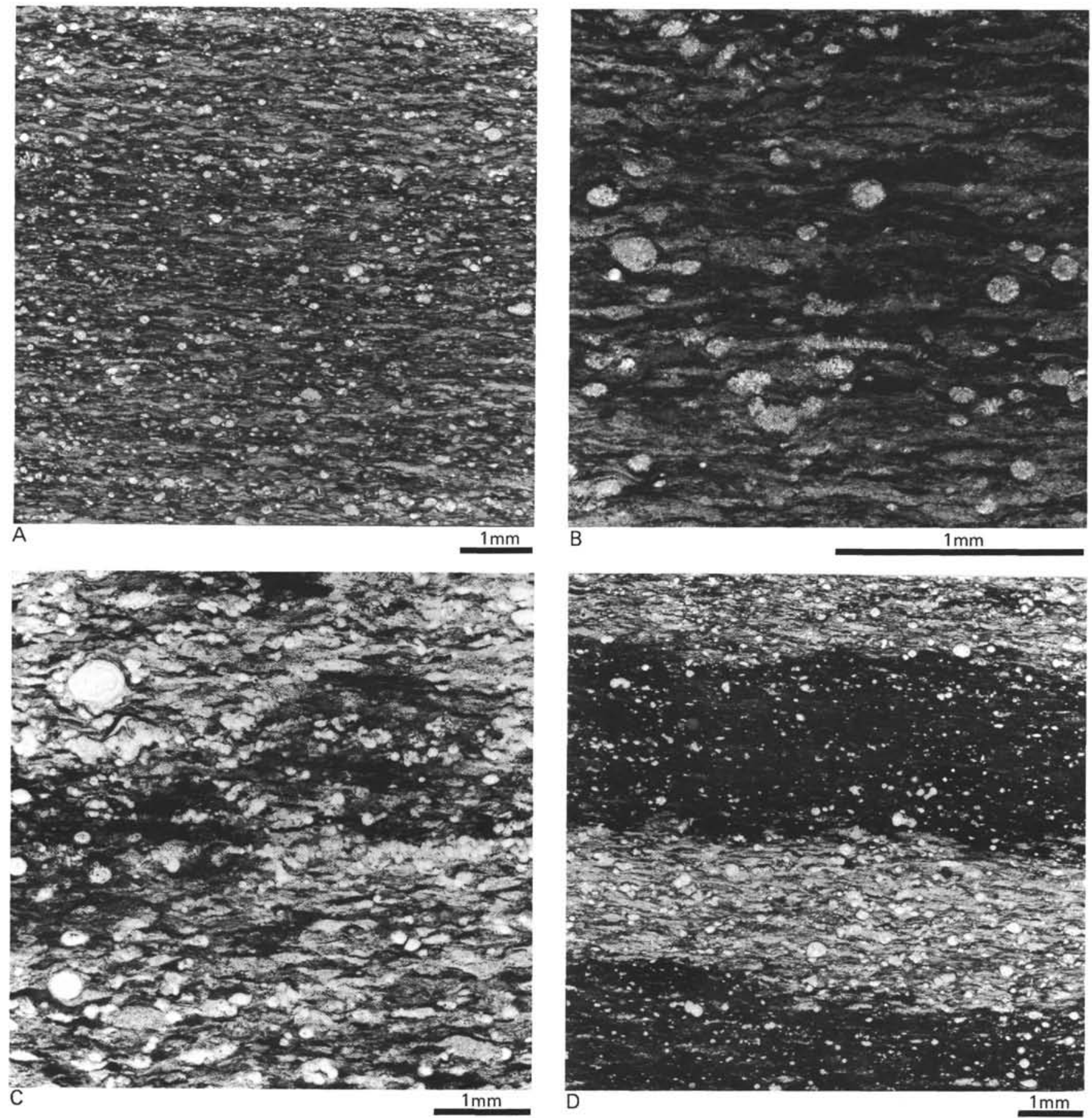

Figure 8. Photomicrographs of the laminated olive-gray limestone of Unit II. All bar scales equal $1 \mathrm{~mm}$. A. 465A-28-2, 53 cm; cross-polarized light; typical laminated limestone. B. 465A-28-2, $53 \mathrm{~cm}$; cross-polarized light; enlargement of Figure 8A, showing partly to completely replaced radiolarians and foraminifers, with discontinuous laminae of dark organic material which is distorted, giving a lens-shaped or "bird's-eye" appearance to the laminae. C. $465 \mathrm{~A}-37-1,134 \mathrm{~cm}$; plane light; laminated gray limestone, illustrating the concentration of radiolarians and foraminifers into layers. D. 465A-28-2, $53 \mathrm{~cm}$; cross-polarized light; darker silicified layers of olive-gray limestones and lighter layers of limestone only partly replaced by silica. 


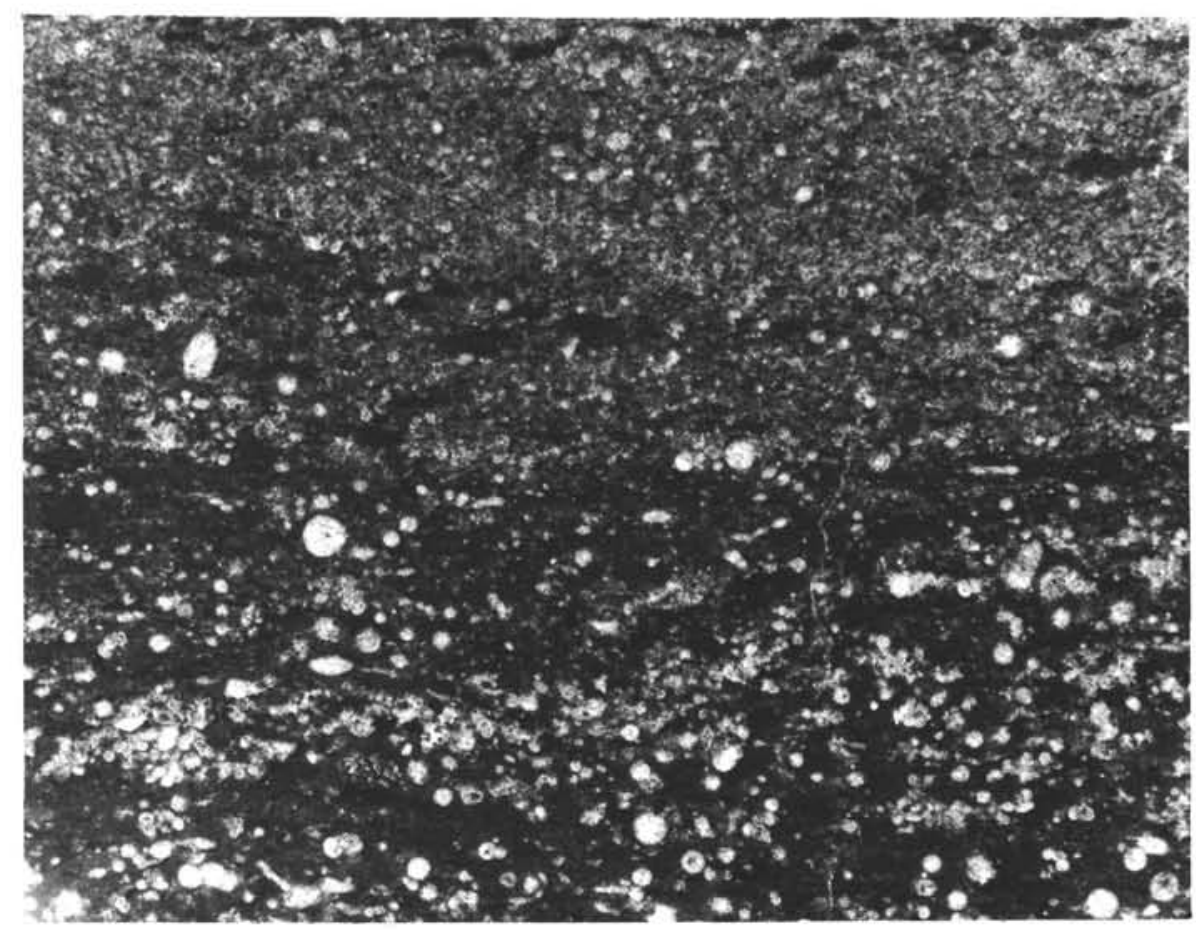

Figure 9. $465 \mathrm{~A}-37-1,126 \mathrm{~cm}$. Contact between laminated olive-gray limestone (bottom) and massive gray limestone (top).

laminated ash (Fig. 13). Between 17 and $34 \mathrm{~cm}$ in Section 2 , Core $40 \mathrm{~A}$, is a bed of clastic dolomite containing veins of large ( $\sim 1 \mathrm{~cm}$ long), bladed crystals of dolomite and large (up to $5 \mathrm{~mm}$ ) crystal aggregates of pyrite.

\section{Unit III: Trachyte (411.7-476 m)}

The trachyte (see additional information in the next section of this chapter) at the top of Unit III is brecciated. The fragments of trachyte are held together by a cement of calcite, dolomite, and barite. The trachyte fragments in the breccia near the top of Unit III are fairly well rounded and are usually "floating"' in calcite, dolomite, and barite cement. With depth, the trachyte fragments become more angular. The amount of cement decreases with depth until the cement is simply vein-filling in fractures in the trachyte. At a depth of about 429 meters sub-bottom, obvious trachyte breccia ends and vesicular trachyte typical of Unit III begins.

\section{Discussion}

The sediments and rocks recovered at Site 465 contain an incomplete record of carbonate sedimentation on top of trachyte that apparently forms the volcanic base of southern Hess Rise. Missing from the record are sediments of early Cenomanian to middle Turonian age, late Coniacian age, and early Campanian age.

The basement at Site 465 consists of trachyte flows that apparently crystallized under relatively low hydrostatic pressure $(<200 \mathrm{~m})$. The first ash beds above the trachyte are water-laid, with cross-lamination suggesting deposition by lateral current flow (Fig. 12). Deposition of abundant organic matter and carbonate along with ash is first recorded in the sediments from 0 to $4 \mathrm{~cm}$ in Section 2, Core 40A. Graded beds of clastic limestone with abundant organic matter occur in Core $40 \mathrm{~A}$, Section $1,116-135 \mathrm{~cm}$. The dominant clasts in the clastic limestone beds are of altered trachyte, and large mollusk fragments are common. We interpret these beds to represent unit A of a theoretical Bouma turbidite sequence; they probably are more-proximal (landward) portions of turbidites. These few bits of evidence-shallow-water or subaerial cooling of the trachyte, current deposition of the ash, high content of organic matter, and graded clastic limestones with clasts of trachyte and abundant mollusk debris-suggest that the first sediments deposited on volcanic basement at Site 465 during the late Albian time were deposited in relatively shallow water (on the order of several hundreds of meters or less). Shipboard data on benthic foraminifers suggest slope water depths in the Albian, deepening to upper bathyal by early Cenomanian.

Sometime after (and perhaps during) the deposition of the first meter of sediment, the sediments were subjected to mineralization. The main manifestations of this mineralization are (1) the abundance of pyrite as disseminated crystals, crystalline masses, thin beds, laminae, lenses, and stringers, (Fig. 14); and (2) the abundance of dolomite as large crystal aggregates and as rhombs replacing the limestone matrix and most of the constituent particles. Typical laminated olive-gray limestone of Unit II begins at about 105-cm in Section 1, Core 40A.

We believe that the most likely mechanism for deposition of the typical laminated limestone of Unit II is turbidity currents. The main types of lamination are concentrations of radiolarians and flaser lamination of 


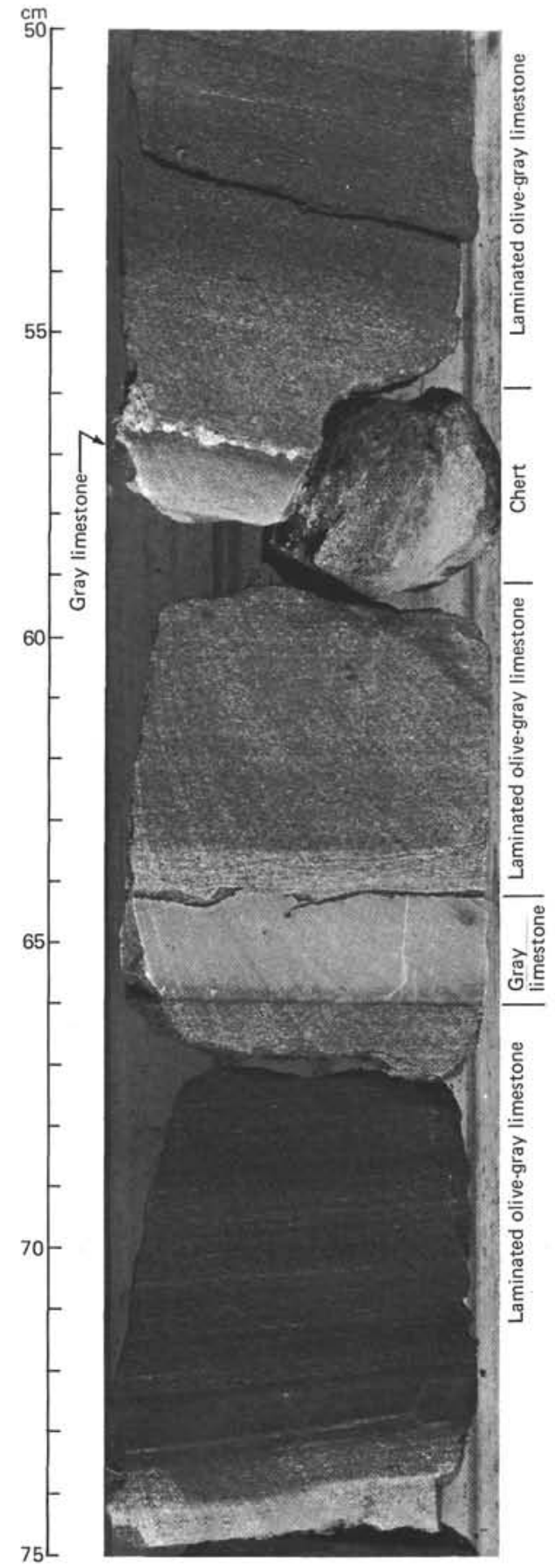

Figure 10. Gray limestone and laminated olive-gray limestone interbeds in Unit II, $465 \mathrm{~A}-36-2,50-75 \mathrm{~cm}$. A chert fragment occurs at 56 to $60 \mathrm{~cm}$.

dark organic material in a micritic calcite matrix. The laminae would be equivalent to upper parallel lamination (unit D) and(or) interturbidites (unit E) of a theoretical Bouma turbidite sequence, interpreted as representing deposition by low-density turbidity currents mixed with pelagic sediments. We conclude that laminated limestone of Unit II represents turbidites that originated up-slope on Mellish Bank. Because of recrystallization, we have no way of knowing how much of the $\mathrm{CaCO}_{3}$ was contributed as pelagic rain and how much was brought in by turbidity currents. However, the abundance of organic material reorganized into flaser laminae, together with redeposited mollusk fragments and shelf benthic foraminifers, suggests downslope movement. The reworking of radiolarians into laminae (Fig. 7) is further evidence of current reworking of pelagic components. The relatively high linear sedimentation rate of the laminated limestone $(48 \mathrm{~m} / \mathrm{m} . \mathrm{y}$.) also supports transport of additional sediment to Site 465 by turbidity currents.

Interpretation of the finely crystalline gray limestones intercalated with laminated olive-gray limestone is a greater problem. These limestone interbeds generally consist of very fine $(<1 \mu \mathrm{m})$ calcite crystals, and exhibit only faint hints of bedding or lamination. They are more silicified than beds of olive-gray limestones. We have discounted the possibility that the fine-grained limestone represents the pelagic component that follows a theoretical Bouma sequence, because if this were the case we would expect the fine-grained limestone to have a gradational and possibly bioturbated lower contact with the underlying laminated limestone, and a sharp erosional upper contact with the overlying laminated limestone. Usually, however, the opposite is observed: the lower contact is sharp and the upper contact is either gradational or sharp (Fig. 9). That the lower contact of the beds of fine-grained gray limestone are sharp and often scoured suggests lateral implacement by currents. One possibility is that the gray limestone was derived from a different, finer-grained source than the olivegray limestone.

A lacuna (early Cenomanian to Santonian), occurs between the limestone of Unit II and nannofossil ooze of Unit I. This is a relatively short hiatus, considering the marked differences in degree of diagenesis and composition between the olive-gray laminated limestone of Unit II and the stark-white, almost structureless nannofossil ooze of Unit I. Unfortunately, the nature of the unconformity between Unit I and Unit II is not known even approximately, because the bottom two cores of Unit II recovered only fragments of chert. However, it is unlikely that the ooze (chalk?), undoubtedly interbedded with chert at depths of 258 to 276 meters subbottom, is much more lithified than the ooze recovered above 258 meters; otherwise, some of the more-lithified sediments would have been recovered. Furthermore, the marked difference in degree of lithification between Units I and II suggests that a considerable amount of material was eroded.

Unit I is a record of normal pelagic carbonate deposition that lasted 80 m.y. in waters that probably were never deeper than at present and that were always above the CCD. This carbonate record is interrupted by two significant lacunas representing an unknown portion of the early Cenomanian to Santonian and Santonian to late Campanian. In addition, there is a major lacuna between the late Paleocene and early Pliocene. Linear sedimentation rates for sediments in Unit I range from 3 to $40 \mathrm{~m} / \mathrm{m}$.y. (late Campanian to early Maastrichtian), but most are $<10 \mathrm{~m} / \mathrm{m}$.y. and are low to normal for 


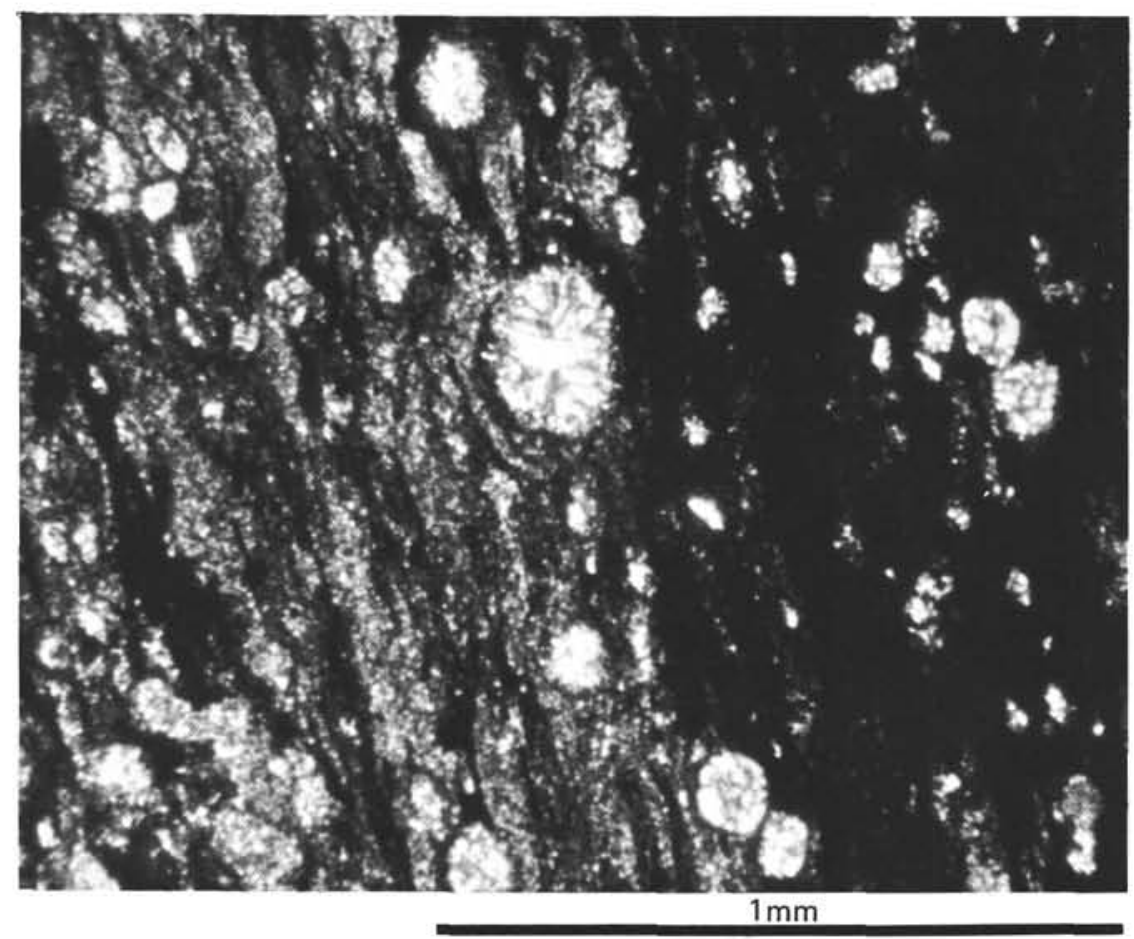

Figure 11. Photomicrograph of contact between chert (right) and silicified limestone in Unit II. Both lithologies contain recrystallized radiolarians and flaser laminations of dark organic matter. Sample 465A-28-2, 53-55 cm (cross-polarized light).

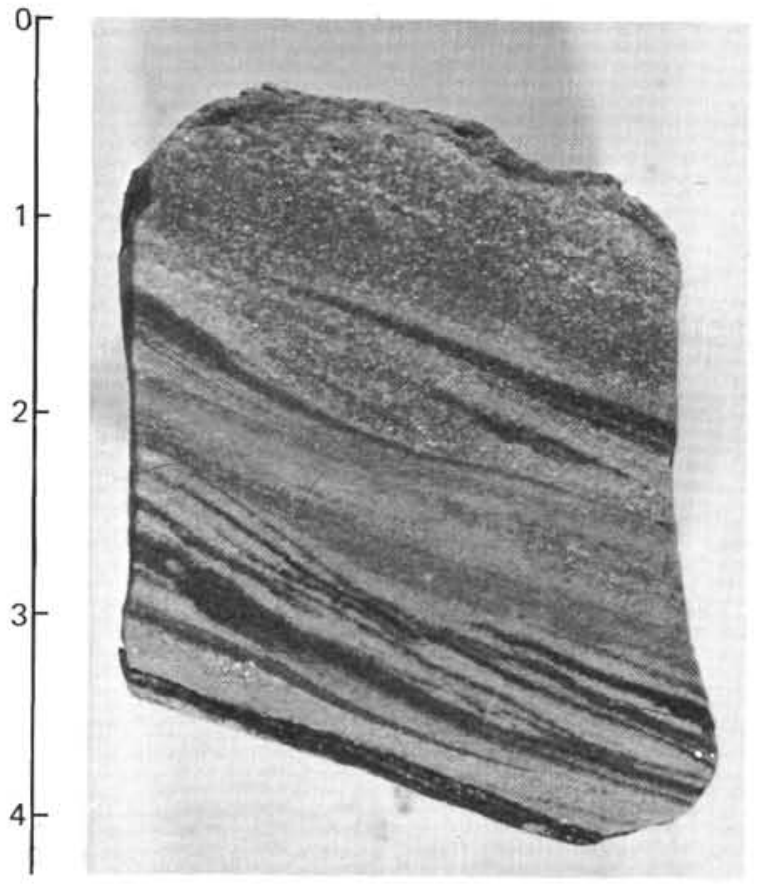

Figure 12. Organic-rich, pyrite-rich water-laid volcanic ash (465A40-2, 0-4 cm).

pelagic carbonate sediments. A high rate of biogenic sedimentation coincident with passing of the site under the equatorial zone of high productivity apparently is not represented in the sediments recovered at Site 465 . Backtracking of the site using the plate-rotation model of Lancelot and Larson (1975) and Lancelot (1978) places the time of equatorial crossing of Site 465 at approximately 90 m.y. ago, during the Turonian. As discussed above, the difference in degree of lithification between Units I and II suggests that a large amount of sediment above the limestones of Unit II was eroded. This sediment, now represented by a lacuna, would have been early Cenomanian to Santonian in age and probably would have been thick as a result of the increased sedimentation rate under the equatorial high-productivity zone. Assuming a linear sedimentation rate of about $48 \mathrm{~m} / \mathrm{m} . \mathrm{y}$. over a period of about $12 \mathrm{~m} . \mathrm{y}$., as much as 600 meters of sediment may have been present and later eroded. Thus, we have two independent lines of evidence that a considerable amount of sediment may have been eroded between early Cenomanian and late Coniacian time.

About 270 meters of remarkably uniform pelagic carbonate ooze were deposited at Site 465 between late Coniacian and late Paleocene time, with only small lacunas within that time (see biostratigraphy section, this chapter). After about 55 m.y. of non-deposition, and possibly some periods of erosion (late Paleocene to Pliocene), the last events recorded at Site 465 is the deposition of a little over 2 meters of nannofossil ooze and foraminifer nannofossil ooze of Plio-Pleistocene age.

\section{IGNEOUS ROCKS}

\section{Introduction}

Igneous rock representing acoustic basement was recovered between 411.7 and 476.0 meters in Hole 465A. Recovery of these igneous rocks averaged $37.1 \%$ (23.9 


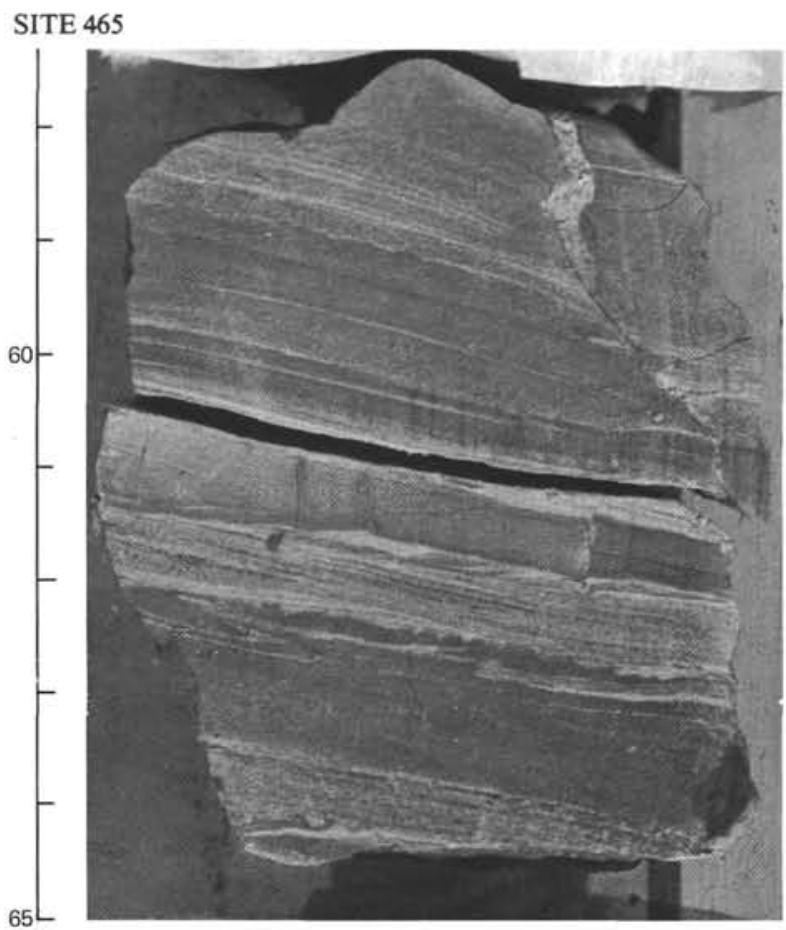

Figure 13. Horizontal and cross-laminated volcanic ash in Unit II, directly above trachyte $(465 \mathrm{~A}-40-2,57-65 \mathrm{~cm})$.

out of 64.3 meters drilled). The upper portion, from 411.7 to 429.0 meters, is breccia composed of bluishgray fragments cemented largely by calcite. Below the breccia, from 429.0 meters to the bottom of the hole at 476.0 meters, the cores consist of highly altered, dominantly fine-grained, vesicular trachyte with feldspar microphenocrysts. The abundant feldspar is surrounded by altered glass and shows varying degrees of flow alignment. Many of the rocks exhibit trachytic texture, although flow orientation ranges from virtually none to highly aligned. Abundant smectite and random mixedlayer clay in all trachyte appears to be derived from alteration of glass and some feldspar. Pyrite decreases with depth; it occurs as disseminated crystals and as fine veins in the trachyte. Numerous clots of greenish-brown clay were observed in thin section; these may represent altered mineral grains (perhaps pyroxene), or simply aggregates of clay. No fresh mafic minerals were observed.

\section{Lithology}

The trachytes are divided into 30 layers that can be grouped roughly into five units (Fig. 15). Some layers display central regions with relatively coarse crystal size and low abundance of vesicles; these regions grade both up and down into regions with finer crystal sizes and higher abundances of vesicles; these are termed flow layers in this report. The remaining layers do not show this kind of variation and are merely designated as layers. Layers are characteristically fine grained and highly vesicular throughout. Because recovery averages $37.1 \%$, only an estimate of the minimum number of layers penetrated is possible. Also, because no continuous core was taken across an entire flow layer, layers listed as flows are probably parts of several different flow layers. It does seem likely, however, that the dominance of fine-grained vesicular trachyte indicates that the section consists dominantly of thin flows.

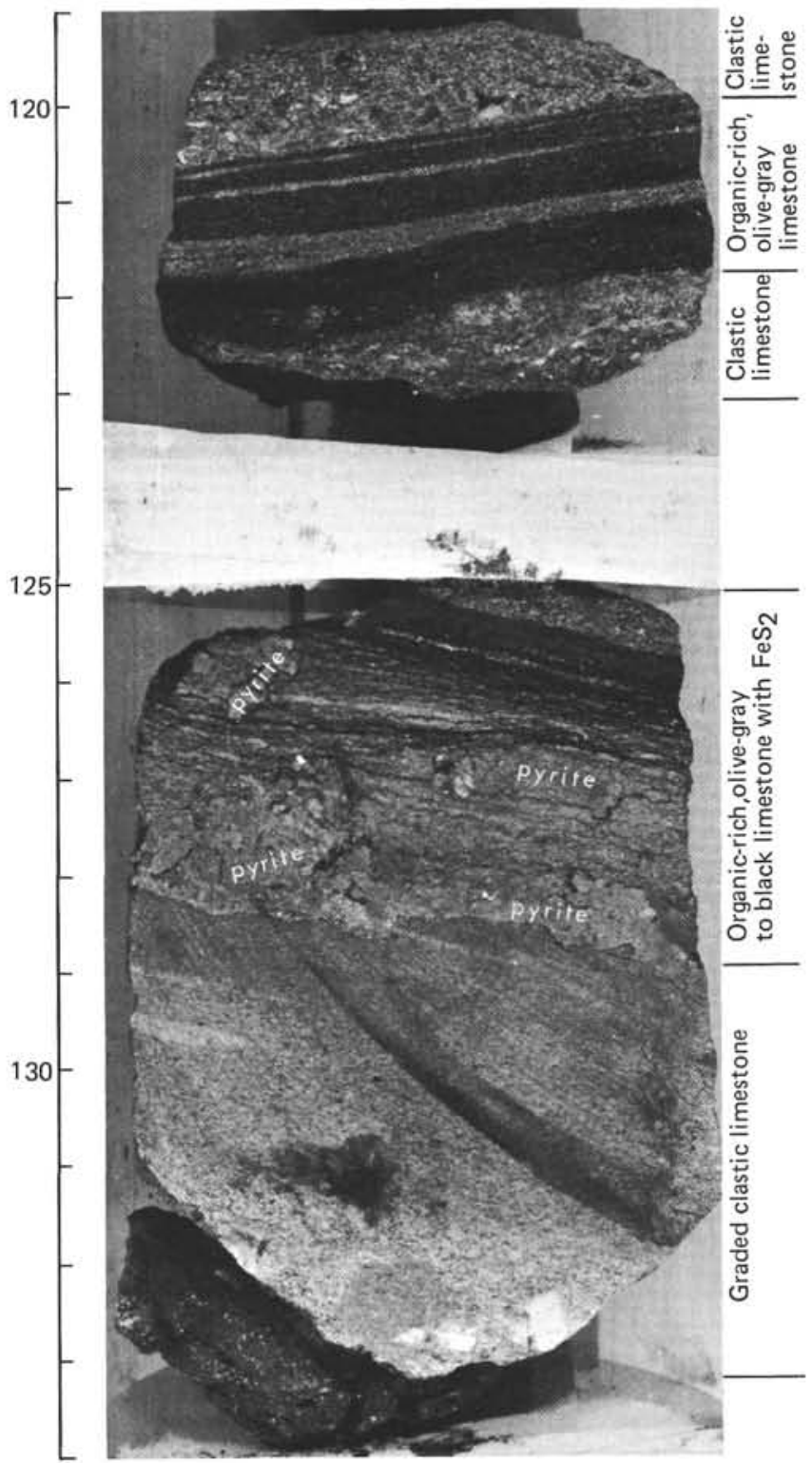

Figure 14. Graded clastic limestone and organic-carbon-rich olivegray limestone, with pyrite as disseminated crystals, thin beds, and lenses. Sample 465A-40-1, 119-134 cm.

\section{Unit 1: Brecciated Trachyte}

This unit extends from 411.7 to 429.0 meters and includes brecciated and fractured trachyte in layers 1 through 5. Individual fragments are blue-gray, grading downward to gray, and may be either massive or layered. The layering is sometimes highly contorted. All groundmass is highly altered to smectite. The dominant cement holding fragments together is calcite covered with a greenish coating, although a barite vein occurs in one fragment. Pyrite is a common accessory mineral in both cement and trachyte. Clasts range from angular to well rounded, the degree of angularity increasing downward. The angular shape of most fragments indicates very little transport, and suggests that brecciation may have been caused by explosive release of trapped volcanic gases. 


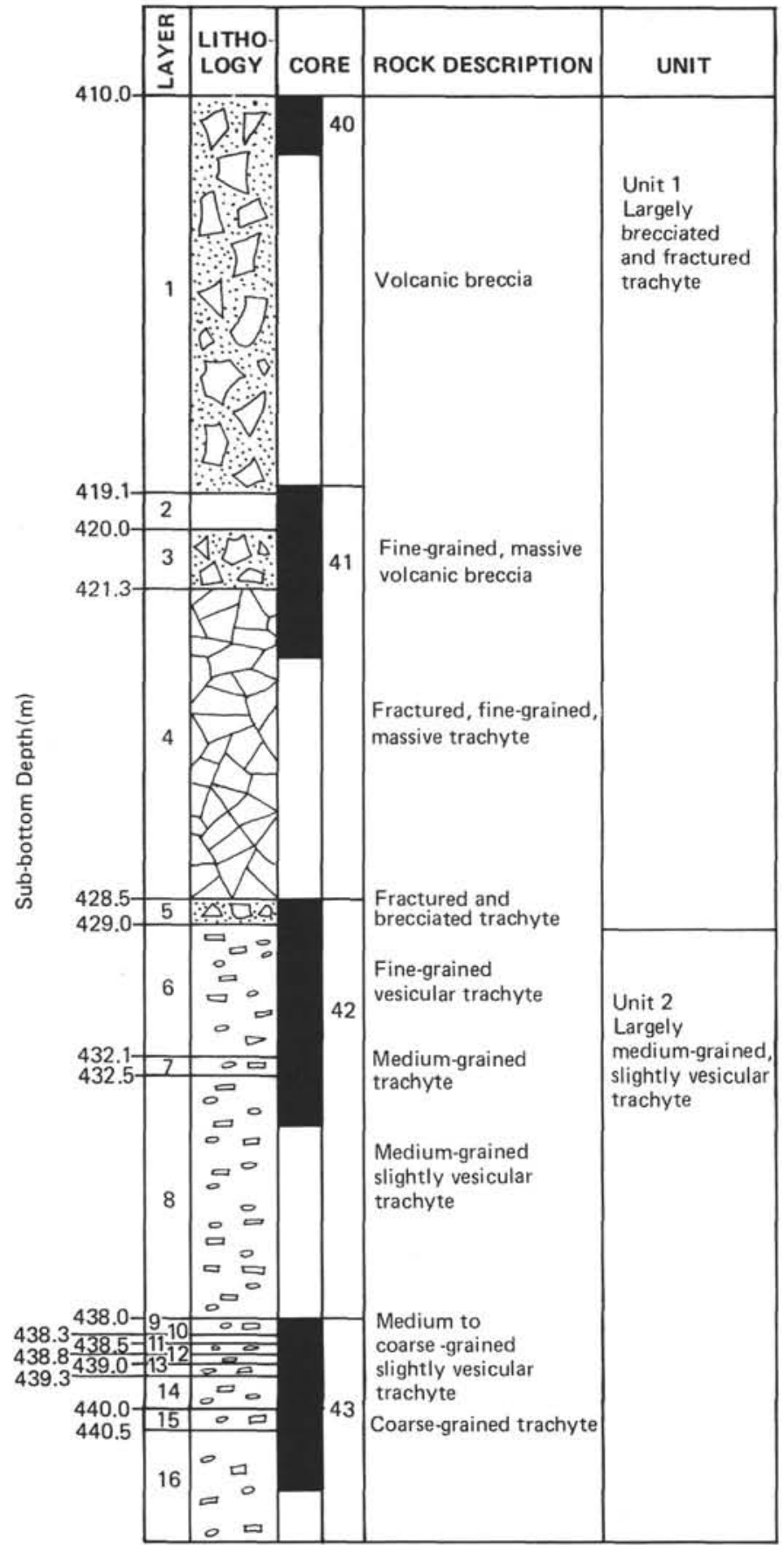

Figure 15. Major units and layers in trachyte from Hole 465A.

\section{Unit 2: Medium-Grained Vesicular Trachyte}

This unit extends from 429.0 to 447.5 meters and includes layers 6 to 16. Layer 6 is fine-grained, but layers 7 through 14 and layer 16 are medium-grained, and layer 15 is coarse-grained. The trachyte is light gray and vesicular, the abundant feldspar microphenocrysts showing varying degrees of flow layering. Pyrite occurs both as disseminated crystals and as thin veins. Layers 7 through 16 have the characteristics attributed to flows: increasing vesicularity and decreasing crystal size away from a central region with few or no vesicles and coarser

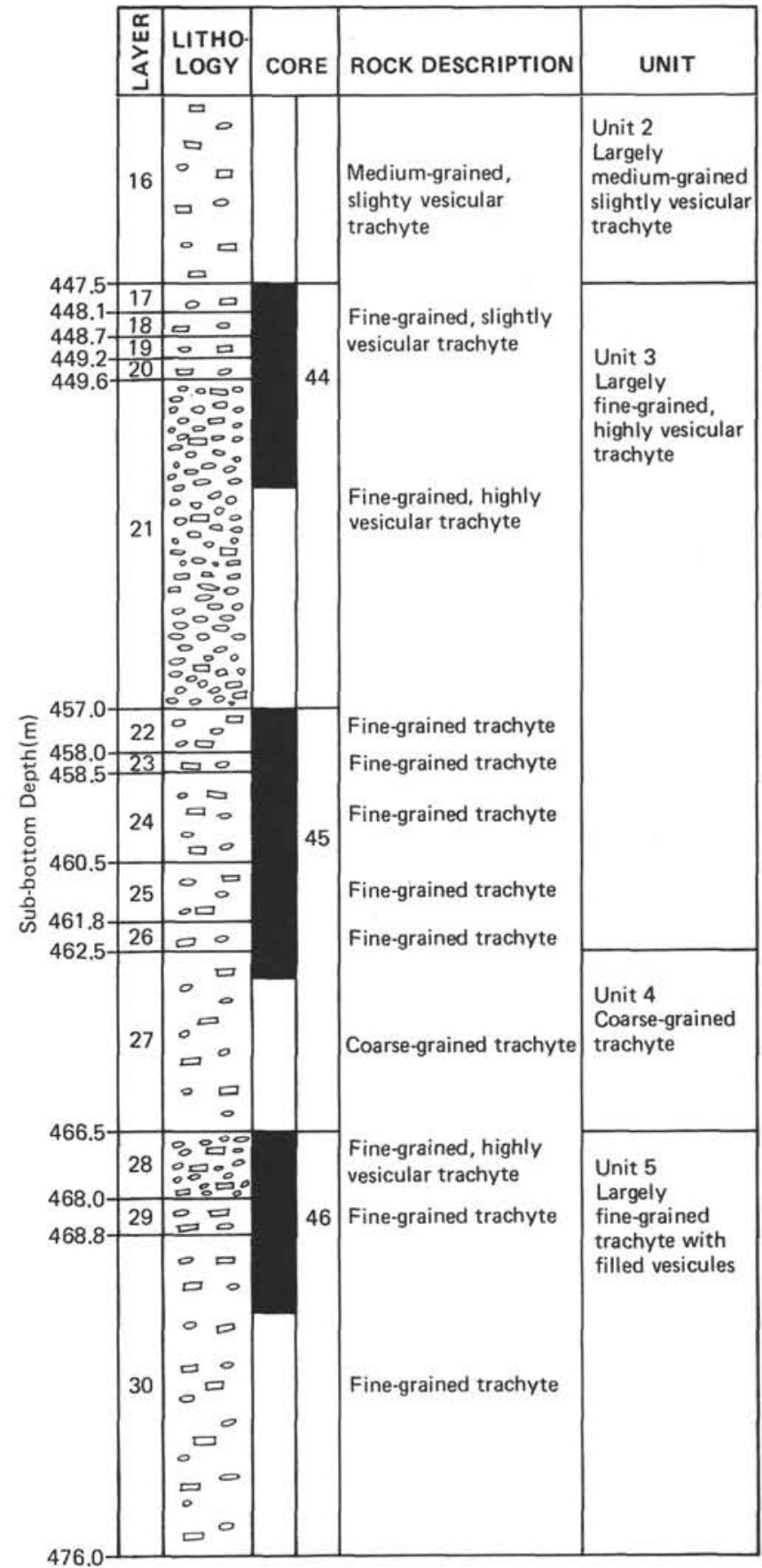

crystal size. Layer 6 does not show these characteristics and cannot be interpreted as a flow on the available evidence. Vesicle size is generally less than or near $1 \mathrm{~mm}$, but some vesicles reach $5 \mathrm{~mm}$. Many vesicles are filled with a lining of smectite and a center of calcite.

\section{Unit 3: Fine-Grained, Highly Vesicular Trachyte}

Unit 3 extends from 447.5 to 462.5 meters and includes layers 17 through 26 . These trachytes are dominantly light gray, fine grained, and vesicular to highly vesicular. The abundant lath-shaped feldspar microphenocrysts and microlites frequently show well-de- 
veloped trachytic texture. Pyrite occurs as finely disseminated crystals and veins. The vast majority of vesicles are $1 \mathrm{~mm}$ or less in diameter, although they range up to about $5 \mathrm{~mm}$, indicating a shallow-water or possibly a subaerial origin. Some vesicles are flattened perpendicular to the length of the core. Layers 17 through 20 , and layers $22,23,25$, and 26 have the characteristics of flows (vesicle abundance and mineralsize variations). Units 21 and 24 represent regions of fine-grained, highly vesicular trachyte that do not show the variations expected of flows. A reddish color was noted in some cores.

\section{Unit 4: Coarse-Grained Trachyte}

Unit 4 includes only layer 27 ; it extends from 462.5 to 466.5 meters, but there was little recovery in this region. As usual, the trachyte is highly altered to soft smectite and random mixed-layer clays; it is light gray in color. Oriented feldspar microphenocrysts are present. Layer 27 appears to be a flow and has a significantly coarser crystal size than do adjacent layers; consequently, it has been designated as a separate unit.

\section{Unit 5: Fine-Grained, Amygdaloidal Trachyte}

Unit 5 extends from 466.5 meters to the bottom of the hole at 476.0 meters; it includes layers 28 through 30. Layer 29 has the characteristics of a flow, but layers 28 and 30 do not. This light-gray trachyte is highly altered and contains abundant flow-oriented feldspar microphenocrysts and microlites. Occasionally an unidentified bright-green mineral (smectite?) is observed, and small amounts of pyrite are disseminated throughout the trachyte. Most vesicles are filled with either a green smectite or white carbonate material, although some pieces of trachyte have little or no vesicle filling. Vesicle size remains the same as in overlying trachyte, being generally near or less than $1 \mathrm{~mm}$, but ranging up to approximately $5 \mathrm{~mm}$.

\section{Petrography}

Petrographic studies of igneous rocks from Hole $465 \mathrm{~A}$ reveal a dominant trachytic texture throughout the cored section. Pervasive alteration has affected all of the rock; the original glass and whatever mafic materials may have been present are altered to brown or greenish-brown smectite and random mixed-layer clay. Alteration of feldspar has also occurred, but to a much smaller degree than alteration of glass.

All studied rocks contain at least one microphenocryst phase. The original phenocryst assemblage consisted of feldspar, and perhaps a mafic mineral; feldspar is by far the dominant phase, accounting for 4 to $8 \%$ of the total rock. Feldspar phenocrysts occur in two distinct sizes: large $(0.5-1.0 \mathrm{~mm})$, euhedral to rhombic crystals, and smaller $(0.04-0.3 \mathrm{~mm})$ laths. The smaller crystals are rarely zoned, but commonly show skeletal growth.

The groundmasses of all studied samples consist of altered glass and feldspar microlites which are usually potash feldspar (Lee-Wong, this volume). Glass was the dominant phase, accounting for 60 to $75 \%$ of the rocks.
The feldspar microlites range in volume from 12 to $30 \%$ of the rock.

All samples can be described as having trachytic texture, with varying degrees of flow layering of lathshaped feldspar microphenocrysts. Three are vesicular, with 2 to $9 \%$ irregularly shaped vesicles. Most vesicles are empty, but some are lined with smectite and filled with calcite. Feldspar microlites commonly are concentrated around vesicle walls.

\section{Chemistry}

Despite the extensive alteration of these rocks, it is possible to determine chemically that they are trachytes (Seifert et al., this volume). The major-element chemistry shows a considerable range for several oxidessuch as $\mathrm{K}_{2} \mathrm{O}$ and $\mathrm{MgO}$ - as well as considerable addition of $\mathrm{H}_{2} \mathrm{O}$ and oxidation. Variations in $\mathrm{SiO}_{2}, \mathrm{~K}_{2} \mathrm{O}$, and $\mathrm{MgO}$ correlate well with $\mathrm{H}_{2} \mathrm{O}$, indicating that these variations are the result of alteration. Nevertheless, the least-altered sample, with the lowest $\mathrm{H}_{2} \mathrm{O}$ content, has the composition of trachyte and is comparable to trachytes from other oceanic regions.

The average percentage values for the trachytes are as follows (compared to the freshest sample, 465A-43-2, 65-68 cm, values of which are in parentheses): $\mathrm{SiO}_{2}$, 59.50 (60.81); $\mathrm{TiO}_{2}, 1.02$ (1.02); $\mathrm{Al}_{2} \mathrm{O}_{3}, 18.73$ (18.80); $\mathrm{Fe}_{2} \mathrm{O}_{3}, 2.98$ (1.98); $\mathrm{FeO}, 0.67$ (0.26); $\mathrm{MnO}, 0.034$ (0.02); $\mathrm{MgO}, 1.00$ (0.31); $\mathrm{CaO}, 2.44$ (1.94); $\mathrm{Na}_{2} \mathrm{O}, 5.10$ (5.32); $\mathrm{K}_{2} \mathrm{O}, 4.88$ (6.27); $\mathrm{P}_{2} \mathrm{O}_{5}, 0.36(0.35) ; \mathrm{H}_{2} \mathrm{O}^{+}, 2.23$ (0.86); $\mathrm{H}_{2} \mathrm{O}^{-}, 2.23(0.64) ; \mathrm{CO}_{2}, 0.60(0.59)$ (see Seifert et al., this volume).

In general, trace elements do not appear to be affected by the alteration, and the rare-earth patterns are very consistent, with strong LREE to HREE enrichment and no significant Eu anomalies. The most interesting feature of alteration in these rocks is the rough correlation between $\mathrm{Lu}$ and $\mathrm{H}_{2} \mathrm{O}$ content; this has not been observed before, to the authors' knowledge.

Average values (ppm) for trace-element concentrations, compared to the least-altered sample (in parentheses), are: $\mathrm{Zr}, 715$ (475); Sr, 308 (256); Ba, 631 (656); Co, 16.6 (19.3); Th, 10.6 (10.2); Hf, 16.9 (15.0); Ta, 9.53 (9.38); Rb, 35.6 (34.3); Sc, 3.06 (2.85); Ce, 170 (167); La, 82.2 (89.1); Sm, 10.5 (9.32); Eu, 3.01 (2.98); and $\mathrm{Yb}, 2.97$ (2.24). $\mathrm{Cr}$ and $\mathrm{Ni}$ have concentrations of less than $10 \mathrm{ppm}$ in all samples.

\section{Summary}

Petrographic, X-ray-diffraction, and chemical studies reveal that the igneous rocks recovered from Hole $465 \mathrm{~A}$ are altered trachytes. All of the original groundmass phases, and some feldspar laths, have been completely altered to one or more smectite minerals and random mixed-layer clays; secondary carbonate minerals are also present in these rocks. Vesicle fillings are complex, with a rim of smectite and a central filling of calcite and perhaps other minerals.

Chemical variations in these rocks correlate with $\mathrm{H}_{2} \mathrm{O}$ content, indicating that the variations result from alteration, not differentiation. Nevertheless, the leastaltered sample is chemically similar to trachytes from 
many oceanic islands. Judging from this, and the trachytic texture, we interpret these rocks as trachytes which probably represent late stage differentiates of alkalic basalt magma.

The abundance and size of vesicles, and the red oxide staining and lack of any glassy flow margins, indicate shallow subaqueous or subaerial volcanism. This implies that at least parts of Hess Rise were near or above sea level prior to late Albian time.

\section{INTERSTITIAL-WATER GEOCHEMISTRY}

Results of shipboard measurements of $p \mathrm{H}$, alkalinity, salinity, calcium, magnesium, and chlorinity in interstitial water from six whole-core sediment samples are presented in Figure 16. The surprising feature of these profiles is that none exhibit significant variation with depth within the 235 meters of nannofossil ooze. There is a slight tendency for calcium to increase with depth (from 10.6 to $13.6 \mathrm{~mm} / \mathrm{l}$ ), and for magnesium to decrease with depth (from 54.0 to $49.6 \mathrm{mM} / \mathrm{l}$ ). An increase in calcium concentration in interstitial waters is commonly observed in carbonate-rich deep-sea sediments, and this is usually matched by a 1:1 molar decrease in concentration of magnesium (see interstitialwater geochemistry for Site 463 , this volume).

This marked inverse relationship between calcium and magnesium concentrations is usually explained by dissolution of $\mathrm{CaCO}_{3}$ and formation of dolomite at depth. The lack of any trends at Site 465 implies that little if any dolomite is forming within the upper 235 meters of sediment, and that either no dissolution of $\mathrm{CaCO}_{3}$ is occurring, or dissolution and reprecipitation are occurring at about equal rates. That nannofossils and foraminifers are moderately well-preserved, and that recrystallized carbonate was commonly observed in smear slides (Appendix A), suggests that both dissolution and reprecipitation indeed are occurring. However, the lack of significant variation in calcium concentration with depth (Fig. 16) suggests that the rate of carbonate dissolution is about matched by the rate of carbonate precipitation.

\section{PHYSICAL PROPERTIES}

\section{Wet-Bulk Density and Sound Velocity}

For unconsolidated sediments of nannofossil ooze and foraminifer nannofossil ooze (Cores 1-10 and 3A21A), wet-bulk density was measured by analog GRAPE method, and sound-velocity measurement was made occasionally on the sample embedded in the liner tube (Fig. 17). For limestone in Cores 26A to 46A, wet-bulk density was measured at a few points per section for whole core-size specimens by using the 2-minute GRAPE method, before the sample was split.

Minicore samples were taken one or two per section for Cores 26A to 46A, and 2-minute GRAPE and gravimetric wet-bulk density and sound velocities in horizontal and vertical directions were measured. All of the measured values of sound velocity, wet-bulk density, porosity, water content, and thermal conductivity at room temperature are shown in Appendix C.
The section recovered at Site 465 has been divided into three major and two minor acoustic units. The major acoustic units correspond well to the lithologic units. The values of wet-bulk density and interval velocity are averaged for each acoustic unit and listed in Table 3.

The least-squares fits to the minicore data of wetbulk density and velocity in Unit II show decrease of values with sub-bottom depth $\left(-0.53 \mathrm{~g} / \mathrm{cm}^{3} / 100 \mathrm{~m}\right.$ for density, and $-2.09 \mathrm{~km} / \mathrm{s} / 100 \mathrm{~m}$ for velocity), although we cannot specify the cause of this decrease.

\section{Thermal Conductivity and Sub-bottom Temperature}

To estimate the terrestrial heat flow at Site 465, thermal conductivity of recovered samples and four downhole temperature measurements were made. Thermal conductivity was measured for each core by using QTM (Quick Thermal Conductivity Meter, Showa Denko Co., Ltd.). Down-hole temperatures, calculated by the Tokyo T-probe technique (Uyeda and Horai, 1979; Yokota et al., 1979), are $6.5 \pm 0.3^{\circ} \mathrm{C}$ at 86.5 meters subbottom depth in Hole 465 , and $10.0^{\circ} \mathrm{C}$ at 172 meters in Hole 456A. The average value of the in situ thermal conductivity of sediments is $3.32 \mathrm{mcal} / \mathrm{cm} \cdot \mathrm{s} \cdot{ }^{\circ} \mathrm{C}$, and the heat flow value of $1.36 \mathrm{HFU}$ is obtained by the method discussed in detail by Fujii (this volume).

\section{PALEOMAGNETISM}

Twenty-six samples of upper Albian limestone and 26 trachyte samples were taken for paleomagnetic measurements (Sayre, this volume). Although most samples carry stable components of magnetization, it is not possible to construct an unambiguous reversal stratigraphy, because magnetic inclinations in both the limestone and trachyte are very low. Variations in susceptibility, the intensity of natural remanence, and Curie temperature indicate that trachyte Units 1 and 2 are highly oxidized and probably have acquired a secondary chemical remanence. In addition, low-titanium titanomagnetites and(or) large magnetic-grain sizes may characterize the center of Unit 3. A paleolatitude estimate indicates that the site was close to the equator during formation of the trachytes.

\section{CORRELATION OF SEISMIC-REFLECTION PROFILES AND DRILLING RESULTS}

Three major lithologic units at Site 465 correspond to the acoustic units. The top unit consists of nannofossil ooze and is 276 meters $(0-276 \mathrm{~m})$ thick. The second unit is limestone, 136 meters (276-411.7 m) thick, and the third is trachyte, encountered at a depth of 411.7 meters. Two major reflectors are apparent on the airgun seismic-reflection profile (Fig. 18). One is at 0.36 seconds two-way time, and the other is at 0.47 seconds. These reflectors mark the boundaries between lithologic units. Reflectors near the top of Unit I probably correspond to acoustic interference caused by the air-gun bubble pulse, but the remaining faint reflectors in that unit are chert layers. The interval velocity $\left(V_{\mathrm{p}}\right)$ calculated for Unit I is about $1.53 \mathrm{~km} / \mathrm{s}$, whereas that calculated for Unit II is about $2.45 \mathrm{~km} / \mathrm{s}$. Velocities measured on small samples in the shipboard laboratory are an 


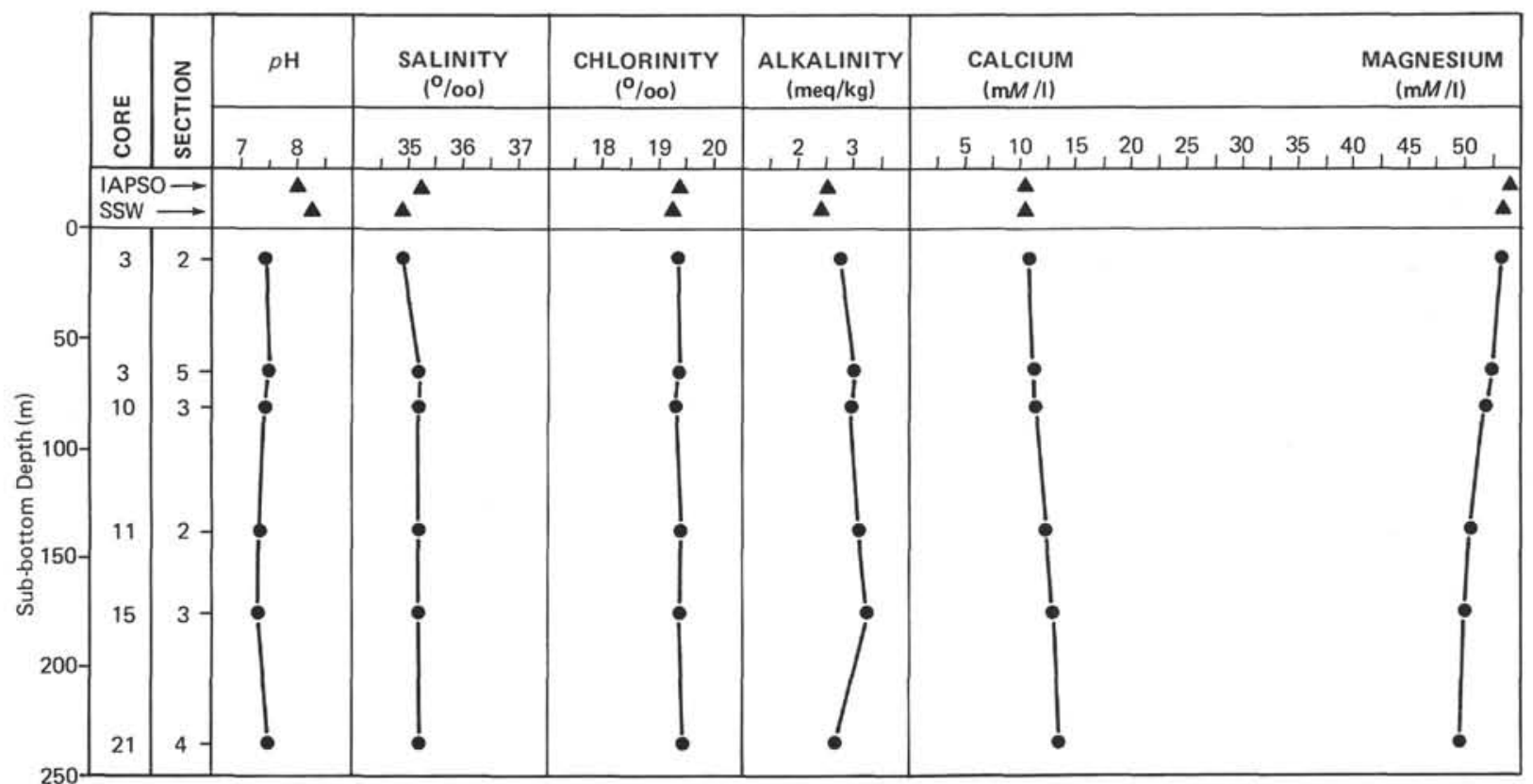

Figure 16. Interstitial-water geochemistry, Site 465 .

average of $1.58 \mathrm{~km} / \mathrm{s}$ for Unit I (range $1.55-1.63 \mathrm{~km} / \mathrm{s}$ ), an average of $2.89 \mathrm{~km} / \mathrm{s}$ for Unit II (range 1.88-4.40 $\mathrm{km} / \mathrm{s}$ ), and $3.60 \mathrm{~km} / \mathrm{s}$ for the trachyte. These values agree well with those that were calculated from the acoustic profile.

\section{BIOSTRATIGRAPHY}

\section{Biostratigraphic Summary}

Sediments of Pleistocene to late Albian age were recovered from two holes at Site 465 on Hess Rise. Most samples contained planktonic foraminifers and nannofossils; benthic foraminifers occurred throughout the section to the upper Albian, but were absent from the last four cores of the hole. Radiolarians occurred infrequently in the Cretaceous, in one sample from the Santonian, and in discrete layers in the Albian limestone.

A summary of the biostratigraphy of this site, based primarily on nannofossils and planktonic foraminifers, is shown in Figure 19.

Pliocene and Pleistocene sediments were recovered in Cores 1 to 2, 0 to 10.5 -meters in Hole 465. The lower Pleistocene and Pliocene down to the middle lower Pliocene are present. Rare diatoms occur in Section 1-1 and belong to the $P$. doliolus Zone of the Quaternary. Below the lower Pliocene sediments there is a mixed interval (Section 2-3, $46 \mathrm{~cm}$ to $2-6,45 \mathrm{~cm}$ ) containing lower Eocene, upper Paleocene, and lower Pliocene materials mixed into upper Pliocene sediments. Foraminifers are very badly dissolved throughout the Pleistocene-Pliocene section.

The Paleogene section contains only Paleocene sediments $(465-2, C C$ to $8, C C, 10.5$ to $67.5 \mathrm{~m}$; and $465 \mathrm{~A}-$ $1, \mathrm{CC}$ to $3-3,144 \mathrm{~cm}, 39$ to $62.4 \mathrm{~m}$ ). The Paleocene section includes all zones. The equivalent of the type Danian is about 11 meters in length (465A, Core 3 ) and the basal Tertiary "Globigerina" eugubina Zone occurs from $465 \mathrm{~A}-3-3,40 \mathrm{~cm}$ to $3-3,144 \mathrm{~cm}$. This is the thickest " $G$." eugubina Zone yet recorded from DSDP cores. Paleocene nannofossils and foraminifers are very well preserved.

Cretaceous sediments were cored at $465-8$ to $11, \mathrm{CC}$ and $465 \mathrm{~A}-3-3,146 \mathrm{~cm}$ to $40-1,138 \mathrm{~cm}(39-411 \mathrm{~m})$. This section includes sediments of the Maastrichtian, upper Campanian, Santonian, lower Cenomanian, and upper Albian. The Cretaceous/Tertiary boundary was recovered and is considered nearly continuous. Microfossils from the Upper Cretaceous sediments are generally well preserved, except in horizons where intense dissolution has occurred. The middle and Lower Cretaceous fossils are only moderately well to poorly preserved; recrystallization of foraminifers is common, and nannofossils are badly etched in the Cenomanian-Albian limestones at the bottom of this hole.

\section{Redeposition}

Redeposited materials such as plant fibers, mollusk fragments, shelf benthic foraminifers, brown clay, and possibly glauconite, occur at several levels in the Cretaceous section. Redeposited materials are commonly found in the upper Maastrichtian M. mura Zone, the upper Campanian $T$. trifidus Zone, the G. concavata$G$. elevata Zone of the Santonian, and throughout the lower Cenomanian to upper Albian limestone sequence. Redeposited radiolarians are most common in the upper Albian limestones.

Whereas the redeposited materials from the Albian to the Coniacian can be attributed to the location downslope from a topographic high, the redeposition later in the Cretaceous probably requires another explanation.

\section{Dissolution Intervals}

Dissolution, in the absence of diagenetic recrystallization, is common in the Upper Cretaceous sediments 


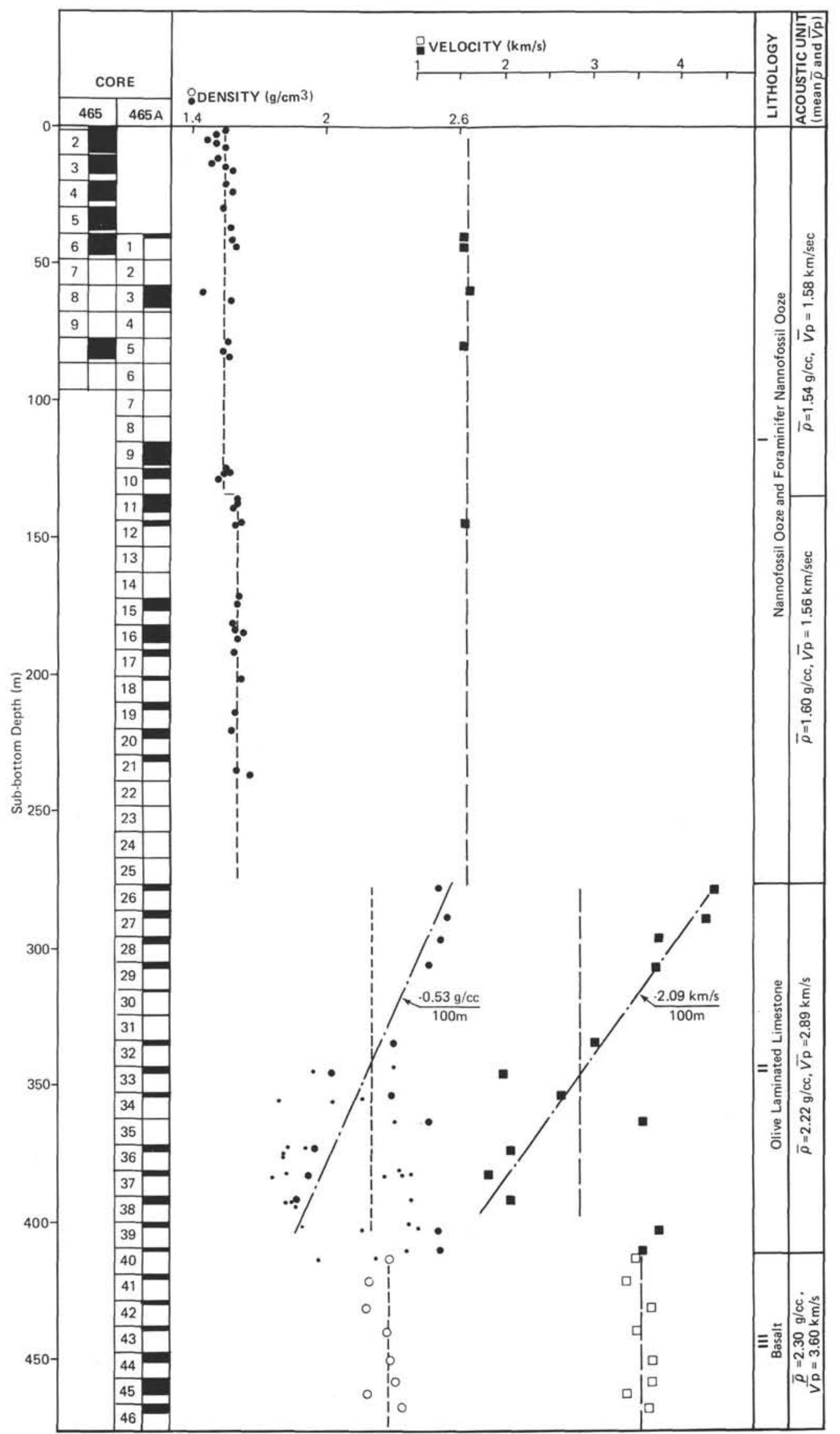

Figure 17. Wet-bulk density and compensated velocity, Site 465 . 
Table 3. Physical properties of acoustic units at Site 465.

\begin{tabular}{|c|c|c|c|c|c|c|}
\hline Unit & $\begin{array}{l}\text { Sub-bottom } \\
\text { Depth } \\
\text { (m) }\end{array}$ & $\begin{array}{l}\text { Density }{ }^{\mathrm{a}} \\
\left(\mathrm{g} / \mathrm{cm}^{3}\right)\end{array}$ & $\begin{array}{l}\text { Velocity } \\
(\mathrm{km} / \mathrm{s})\end{array}$ & $\begin{array}{c}\text { DT } \\
(\mathrm{sec})\end{array}$ & $\begin{array}{c}\text { Thermal } \\
\text { Conductivity } \\
\left(\mathrm{mcal} / \mathrm{cm} \cdot \mathrm{s} \cdot{ }^{\circ} \mathrm{C}\right)\end{array}$ & $\begin{array}{c}\text { Lithologic } \\
\text { Unit }\end{array}$ \\
\hline I & $0-276$ & - & - & - & - & I \\
\hline IA & $0-135$ & 1.54 & $1.58 \quad$ (4) & 0.17 & 3.50 (9) & \\
\hline IB & $135-276$ & 1.60 & 1.56 (1) & 0.18 & 3.56 (5) & \\
\hline II & $276-412$ & $2.26^{\mathrm{b}}$ (11) & $3.06^{\mathrm{b}}$ (11) & 0.09 & 4.41 (10) & II \\
\hline III & $412-$ & $2.30 \quad(8)$ & 3.60 (7) & - & 3.38 (7) & III \\
\hline
\end{tabular}

a Number of samples averaged in parentheses.

$b$ Averages neglecting data from Cores 39 and 40.

at Site 465. Undissolved foraminifers and coccoliths are moderately well preserved. There are, however, discrete levels where dissolution is so intense as to badly etch the nannofossils and dissolve most of the globotruncanids. In the upper Maastrichtian, there are even dissolution leveis where all planktonic foraminifers are removed. Intervals intense dissolution include the upper Maastrichtian (M. mura Zone), the Maastrichtian to upper Campanian (T. trifidus Zone), the lower Santonian, and the upper Albian.

\section{Nannoplankton}

Nannofossils are present in the 11 cores of Hole 465, and in all cores of Hole $465 \mathrm{~A}$ to the trachyte (465A-40). In the nannofossil and foraminifer nannofossil oozes of Unit I, nannofossil assemblages of Pliocene to Pleistocene age, of early Paleocene to late Campanian age, and of Santonian to late Turonian age were recovered. In the olive-gray laminated limestones of Unit II, nannofossil assemblages are readily assignable to two zones of late Albian to Cenomanian age. Samples from Section $465 \mathrm{~A}-40-1$, just above the trachyte, belong to the late Albian Eiffellithus turriseiffeli Zone (100-104 m.y.).

\section{Cenozoic}

In samples from Core 1 and the top of Core 2 (to 2-1, $125 \mathrm{~cm})$, well-preserved assemblages of the Pseudoemiliania lacunosa (NN19) Zone of early Pleistocene age are present. Reworked Pliocene discoasters are present in some of these samples. In samples from 2-1, 147 $\mathrm{cm}$ to $2-3,41 \mathrm{~cm}$, a diverse assemblage of discoasters, abundant Pseudoemiliania lacunosa, and rare Reticulofenestra pseudoumbilica are found. The joint occurrences of these species, without considering complications of possible reworking, place these samples in the zonal interval NN14 to NN18. It is plausible that lower Pliocene species such as Reticulofenestra pseudoumbilica and Discoaster asymmetricus could be reworked into upper Pliocene assemblages (NN16-NN18).

In samples from the interval $2-3,46 \mathrm{~cm}$ to $2-6,45 \mathrm{~cm}$, the nannofloras show a mixing of components of three different ages in a random fashion (one of the following, two of the following, all of the following): Pliocene (NN14-NN18), early Eocene (NP13), and late Paleocene (NP9). One set of samples in the interval 2-3, $46 \mathrm{~cm}$ to 2-3, $147 \mathrm{~cm}$ includes an unmixed flora of late Eocene age. Moderately well-preserved assemblages of the Discoaster lodoensis (NP13) Zone are recognized. It is not known whether this mixing occurs naturally or represents drilling disturbance. Natural mixing is considered more likely, and the lower Eocene sediment is interpreted as displaced into the Pliocene.

A sequence of zones spanning the entire Paleocene is recognized in Holes 465 and $465 \mathrm{~A}$. Most nannofloras are moderately well preserved, often showing a combination of etching and overgrowth. This makes it difficult to make a definite age determination in some inter-

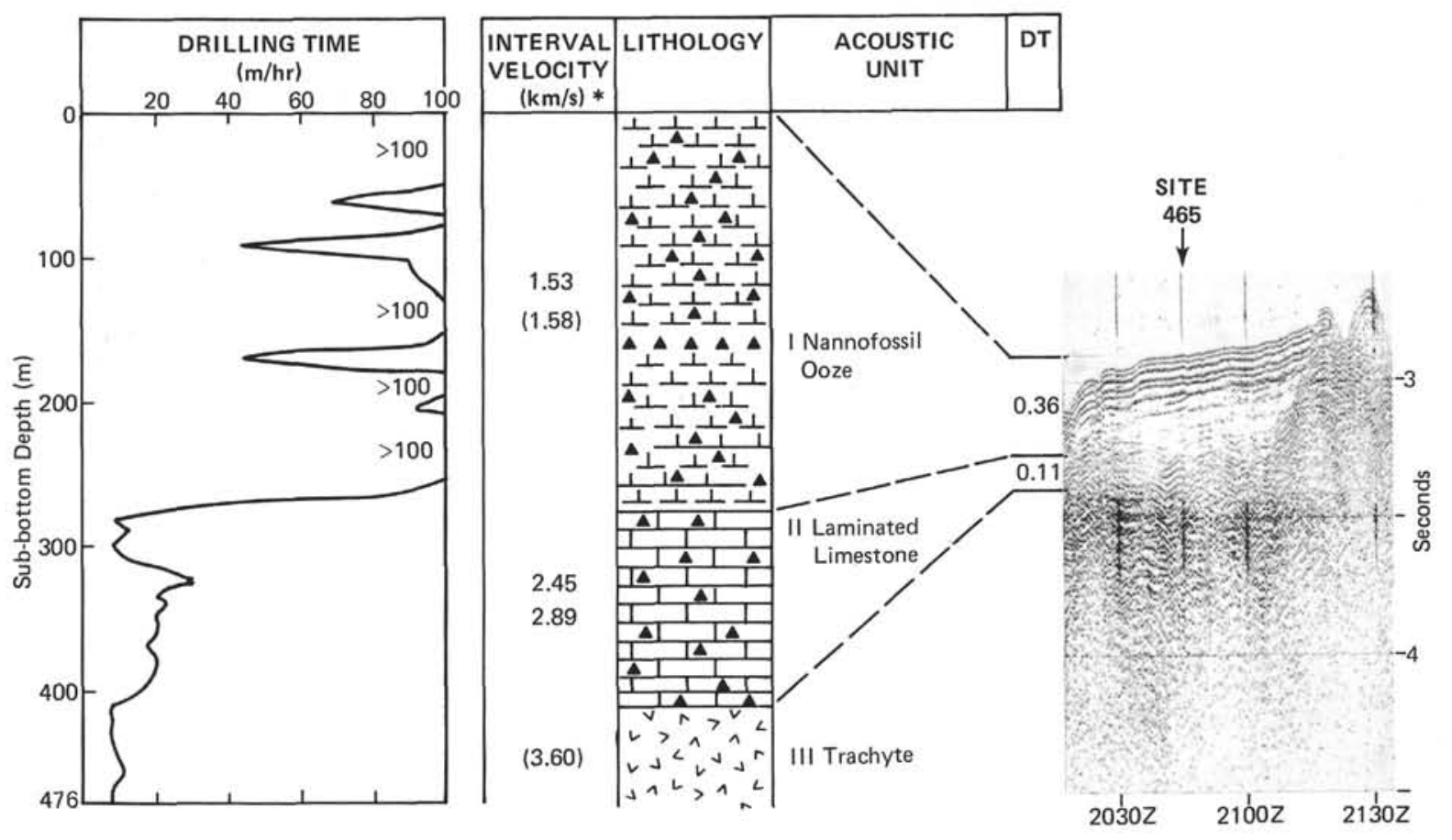

Figure 18. Correlation of seismic-reflection profiles and drilling results, Site 465 . Values from laboratory measurements are shown in parentheses. 
vals. Sample 2, CC contains a diverse nannoflora of the Discoaster multiradiatus Zone of late Paleocene age. Samples 3,CC and 4,CC are assigned to the Discoaster mohleri (NP7)/Heliolithus riedelli (NP8) zonal interval of late Paleocene age. Samples 5,CC and 1A,CC belong to the Heliolithus kleinpellii (NP6) Zone of early Paleocene age.

Sample 6,CC contains a poorly preserved nannoflora of the Fasciculithus tympaniformis (NP5) Zone. Because of bad preservation, Sample 7,CC is assignable only to the Chiasmolithus danicus (NP3)/Ellipsolithus macellus (NP4) zonal interval. Sample 2A,CC, a betterpreserved sample, has a nannoflora indicative of the Chiasmolithus danicus (NP3) Zone of early Paleocene age. In Sample 8,CC, most coccoliths have etched centers, but specimens transitional from Cruciplacolithus to Chiasmolithus are present. This sample is tentatively assigned to the Cruciplacolithus tenuis (NP2)/Chiasmolithus danicus (NP3) zonal interval.

In samples from $3 \mathrm{~A}-1$ to $3 \mathrm{~A}-3,128 \mathrm{~cm}$, exceptionally well-preserved nannofloras were observed. They are characterized by an abundance of Thoracosphaera fragments. Very small coccoliths (1-2 $\mu \mathrm{m})$ are also present, indicating that almost no dissolution of the coccolith assemblages has occurred. Rare to few Markalius inversus and very rare Biantholitus sparsus are found in some sample intervals. No specimens of Cruciplacolithus tenuis or Chiasmolithus spp. were found; these samples are assigned to the Markalius inversus (NP1) Zone of earliest Paleocene age.

\section{Mesozoic}

Predominantly abundant and moderately well-preserved nannofossils are found throughout the Upper Cretaceous section. Poorly preserved calcareous nannofossils were commonly recovered from the Lower Cretaceous. A sequence of nine nannofossil zones or zonal intervals has been recognized:

1) Upper Maastrichtian (3A-3, $120 \mathrm{~cm}$ to $3 \mathrm{~A}, \mathrm{CC})$; Micula mura Zone.

2) Middle to Upper Maastrichtian (9,CC to 11,CC; 4A,CC); Lithraphidites quadratus Zone.

3) Lower Maastrichtian $(6 \mathrm{~A}, \mathrm{CC}$ to $11 \mathrm{~A}-5,8-9 \mathrm{~cm})$; Arkhangelskiella cymbiformis Zone.

4) Upper Campanian to Lower Maastrichtian (11A, CC to 19A,CC); Tetralithus trifidus Zone.

5) Upper Campanian (20A-1, 33-34 cm to 20A,CC); Tetralithus gothicus Zone.

6) Lower to middle Campanian (21A-3, $135-136 \mathrm{~cm}$ to $21 \mathrm{~A}-4,43-44 \mathrm{~cm}$ ); Broinsonia parca Zone.

7) Coniacian to Santonian (21A,CC to $23 \mathrm{~A}, \mathrm{CC})$; the abundant assemblages in this interval are characterized by the absence of certain index species important to the zonation; the upper limit of this zonal interval is determined by the first occurrence of Broinsonia parca, and the lower limit by the last occurrence of Lithraphidites acutum, and by the first occurrence of Eiffellithus eximius, Micula staurophora, and Lithastrinus grilli.

8) Uppermost Albian to Cenomanian (26A-1, 14-15 $\mathrm{cm}$ to $27 \mathrm{~A}, \mathrm{CC})$; Lithraphidites alatus Zone.

9) Upper Albian (28A-1, 58-59 cm to 40A-1, 139$140 \mathrm{~cm}$ ); Eiffellithus turriseiffeli Zone.

\section{Foraminifers}

\section{Neogene}

Neogene sediments were recovered only in Core 465-1 and part of Core 465-2. Core 465-1,CC is of Pleistocene age (N22), judging from the presence of Globorotalia truncatulinoides. The foraminifer fauna is poorly preserved, as indicated by a very large amount of fragmentation. The planktonic assemblage is typical of temperate water. Globorotalia inflata is abundant and dominates the assemblage; Globigerina bulloides is common. Rare species include Globigerinoides ruber, Globorotalia scitula, G. crassaformis, and G. truncatulinoides. At nearby DSDP Site 310, the two temperate species $G$. inflata and $G$. bulloides are also among the main components of the Pleistocene planktonic fauna. Neogloboquadrina pachyderma, however, which constitutes $40 \%$ of the fauna in the uppermost sediments (upper part of Core 1) at the latter site, is very rare at Site 465. Uvigerina peregrina disrupta is the most common benthic-foraminifer species, as is often the case in Pacific benthic-foraminifer assemblages at this water depth.

\section{Paleogene}

A nearly complete section of Paleocene sediments can be assembled by the combination of the sections of Holes 465 and 465A. Planktonic foraminifers are well preserved throughout the section, particularly in the Danian, which is about 11 meters thick in Hole 465A. The controversial basal Tertiary "Globigerina" eugubina Zone occurs at $465 \mathrm{~A} 3-3,40 \mathrm{~cm}$ to $3-3,144 \mathrm{~cm}$. This is the thickest " $G$." eugubina Zone recorded in the deep sea.

At the top of the Paleocene section, planktonic foraminifers occur in diverse assemblages typical of tropical waters. Morozovella velascoensis is large, with wide, open umbilici and almost cantilevered chambers. Morozovellids and acarinids are very diverse; subbotinids in Zone P4 are very large; chiloguembelinids are rare and flat.

Foraminifer populations change in Zone P3b (465-5 to $6, \mathrm{CC}$ ), not only in species content, but also in morphotypic expression. Morozovellids become tightly coiled, with closed umbilici, and benthic forms are more abundant $(6, C C)$.

The planktonic-foraminifer association in Zone $\mathrm{P} 1$ is unusual (465-8,CC; 465A-2-3, $144 \mathrm{~cm})$. Chiloguembelinids dominate all faunas, while other species are very rare. Guembelitria cretacea dominates the $G$. eugubina faunas at lower levels, but it is replaced by $G$. eugubina at higher levels. Little or no reworking of Cretaceous material is found in samples from $3-3,40 \mathrm{~cm}$ to $3-3,100 \mathrm{~cm}$; this lack of admixed Cretaceous is unique. Mixing of Cretaceous and the "G." eugubina fauna progressively increases below $3-3,110 \mathrm{~cm}$ to $3-3,142$ $\mathrm{cm}$, presumably because of the disturbance of coring.

\section{Cretaceous/Tertiary Boundary}

The Cretaceous/Tertiary boundary is at $465 \mathrm{~A}-3,144$ $\mathrm{cm}$. The boundary is actually spread through a mixed zone approximately $30 \mathrm{~cm}$ in length. Well-preserved 


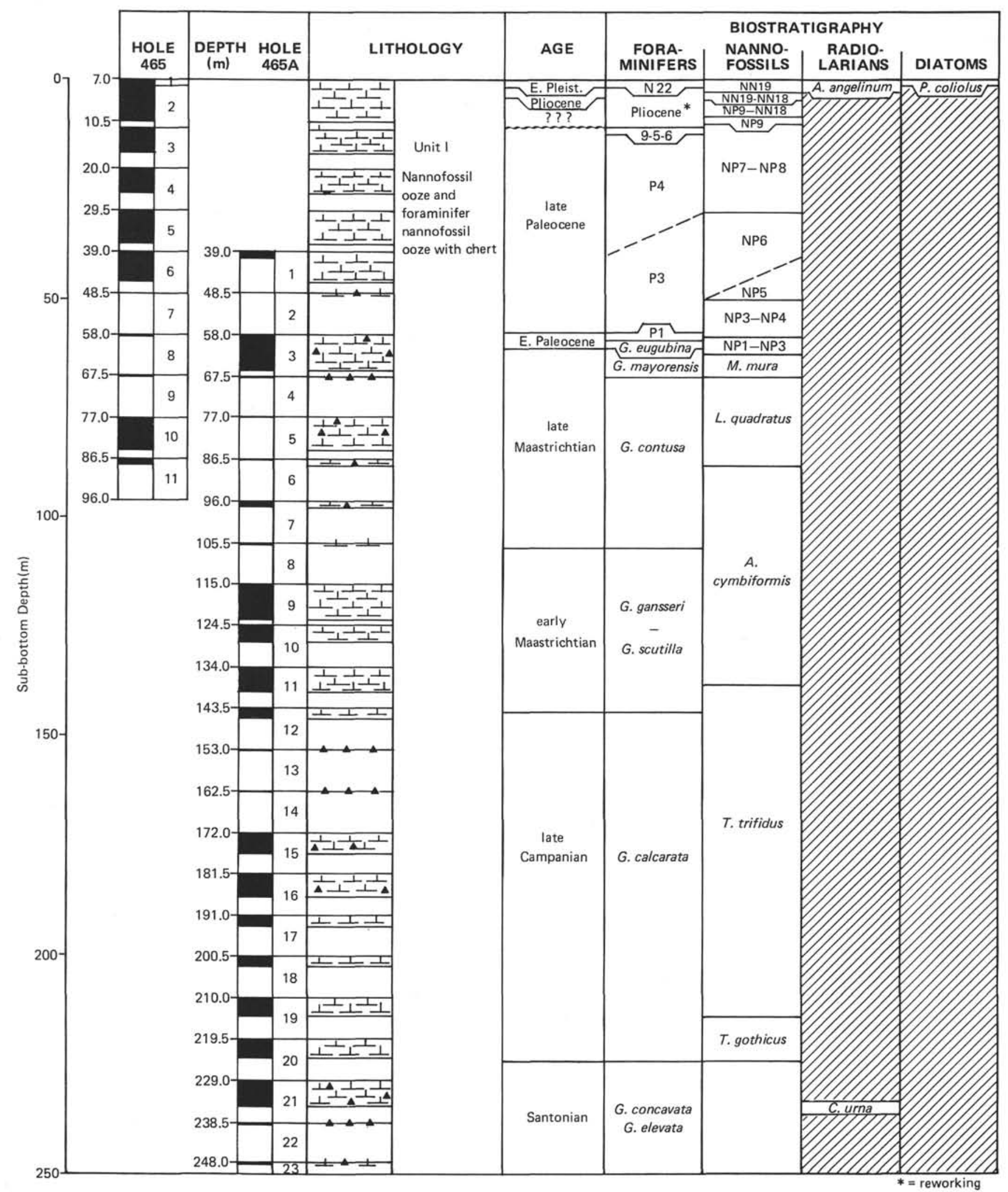

Figure 19. Biostratigraphy of Site 465 . 


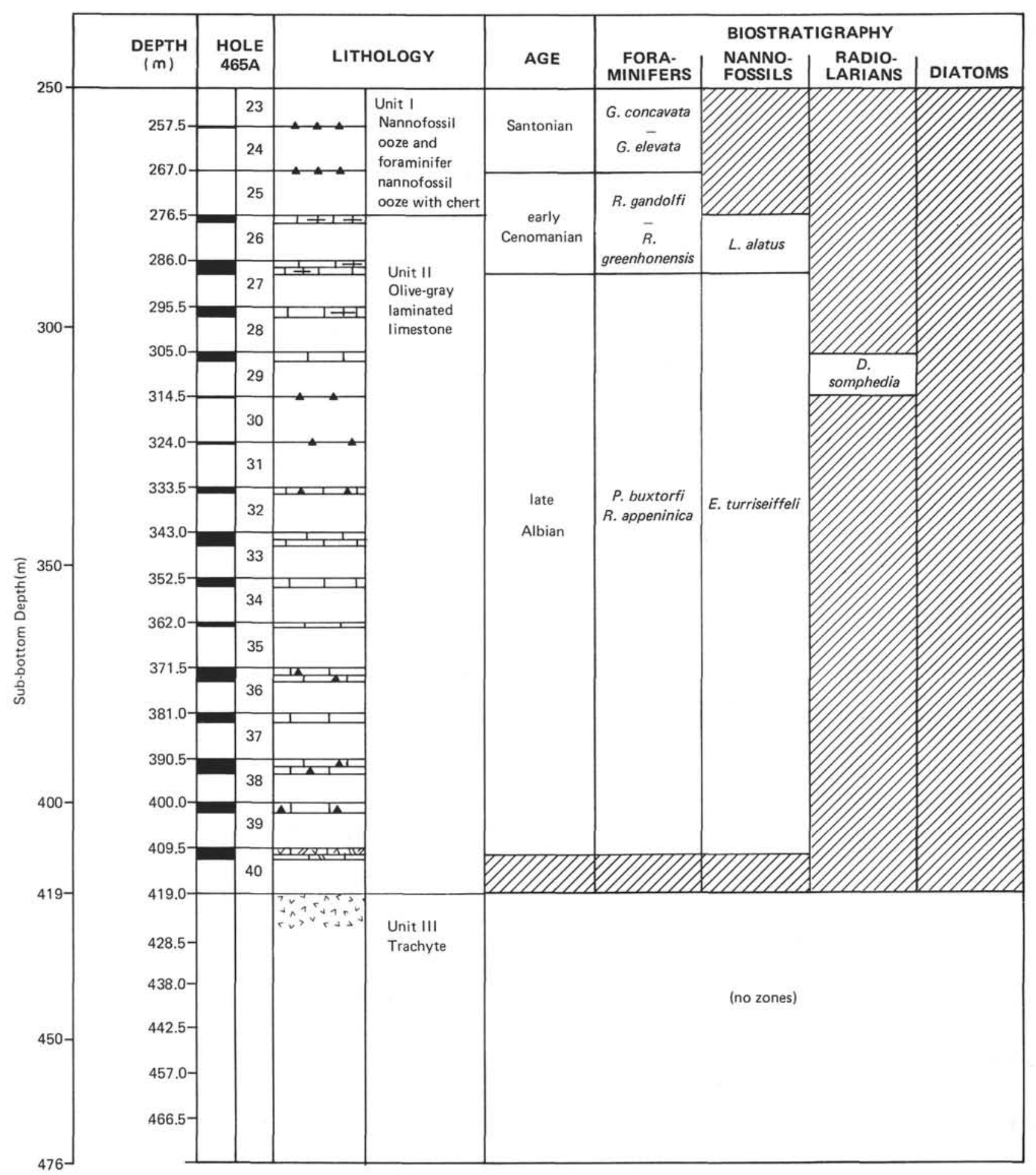

Figure 19. (Continued).

latest Cretaceous fossils occur in discrete white stringers through light-gray Tertiary sediments.

\section{Cretaceous}

Cretaceous sediments were recovered from Cores 9 to $11, \mathrm{CC}$ in Hole 465 and 3-3, $146 \mathrm{~cm}$ to $4-2$ in Hole $465 \mathrm{~A}$.
Maastrichtian. The A. mayaroensis (465A-9 to $11, C C ; 3-3$ to $3-5), G$. gausseri (9-2 to $10-1)$, and $G$. scutilla $(10-2$ to $14, C C)$ zones were recognized. Aside from several levels (465-9,CC; 465A-12,CC; 465A-3-6, $50 \mathrm{~cm}$ ) where most of the planktonic foraminifers are dissolved, Maastrichtian planktonic foraminifers are diverse and well preserved. Benthic foraminifers are rare. 
Campanian. The G. calcarata $(14, C C$ to $20-2)$ and $G$. elevata (20-3 to 22,CC) zones were recognized. Foraminifers are well preserved; the benthic forms are rather rare.

Santonian. The very short $G$. elevata Zone belongs to the Campanian, according to accompanying nannofossils. Thus, only the early Santonian G. concavata-G. elevata Zone $(23, \mathrm{CC})$ was determined. Foraminifers are frequently highly dissolved; some of the benthic foraminifers appear to be redeposited.

Turonian-Coniacian. The $G$. rengi-G. sigali Zone was recognized from 24 to $25, \mathrm{CC}$. In these samples, dissolution and recrystallization are intense. Inoceramus prisms occur in the coarse fraction.

Albian. The $R$. apenninica-P. buxtorfi Zone (28-1 to 40-1) was recognized. The badly recrystallized planktonic faunas were dominated by hedbergellids. Only one specimen of $P$. buxtorf $i$ was found throughout the interval. The few moderately diverse assemblages (34-1) contain Praeglobotruncana, Ticinella, and Rofalipara species. At several levels, woody fiber and uniform-sized mollusk fragments occur (40-1). Recrystallization and distortion of foraminifers increase toward the bottom, until all are dissolved below 40-1.

\section{Coarse-Fraction ( $>63 \mu \mathrm{m}$ ) Components; Abundance and Preservation of Foraminifers}

A visual estimate of the relative abundance of the main components of the sediment coarse fraction is presented in Appendix D.

In the Cenozoic and Upper Cretaceous oozes (Lithologic Unit I; Cores 465-1 through 465A-25), planktonic foraminifers are the dominant constituent of the coarse fraction. In these sediments, there are rare occurrences of ostracodes, mollusk, and echinoderm fragments. Radiolarians are rare in the Neogene (Core 465-1), and absent in the remainder of the interval except for one horizon in the Santonian (Core 465A-21), in which they are abundant, dominating the coarse fraction. Chert fragments are rare to common throughout the Paleocene and Upper Cretaceous.

Planktonic foraminifers are poorly preserved in the Neogene (Core 465-1) and greatly fragmented. They are well preserved in the Paleocene and upper Maastrichtian (Cores 465-2 through 10 and 465A-1 and 2), except for one interval with pronounced dissolution in the upper Maastrichtian (Cores 465-10 and 465A-3), in which planktonic foraminifers are rare or absent, so that benthic species dominate the foraminifer assemblages. Foraminifers are moderately well preserved in the lower Maastrichtian to Santonian (Cores 465A-6 through 23), and poorly preserved in the lower Santonian to upper Coniacian (Cores 465A-24 and 25).

In the lower Cenomanian and upper Albian limestones (Lithologic Unit II; Cores 465A-26 through 40, Section 1), the coarse fraction is dominated by limestone chips and planktonic foraminifers, each alternating as the main component. Throughout this interval, planktonic foraminifers are poorly preserved, because of significant recrystallization.
In Cores $465 \mathrm{~A}-27$ to 33 , limestone chips dominate the coarse fraction, except at one horizon in Core 32, in which quartz grains are the main constituent.

\section{Radiolarians}

At Site 465, radiolarians are rare, and preservation is generally poor (see Schaaf, this volume).

Only the first two cores of Hole 465 (up to 2-2, 120 $\mathrm{cm}$ ) contained common to rare but poorly preserved radiolarians of the Axoprunum angelinum Zone (late Pleistocene). By comparison with Site 464 , this fauna includes more high-latitude species, although it lies at lower latitudes; $P$. murrayana is the only low-latitude species found in this assemblage. The Cenozoic sections of Hole $465 \mathrm{~A}$ are barren.

Two cores (21 and 29) contain radiolarians. In Core 21 , a poorly preserved association with $A$. urna, $P$. superbus, $D$. torquata, and $D$. duodecimcostata can be assigned to the Artostrobium urna Zone. Core 29 contains fairly abundant, well-preserved radiolarians such as $L$. petila, H. barbui, A. cortinaensis, and A. stocki, from the Dictyomitra somphedia Zone. The absence of species of Subfamily Saturnalinae is noteworthy, as these species occur commonly through the Cretaceous at these latitudes.

\section{SEDIMENTATION RATES}

Average rates of sedimentation at Site 465 are shown in Figure 20; data for the figure are given in Table 4. Sedimentation commenced in the late Albian to early Cenomanian at a rate at $48 \mathrm{~m} / \mathrm{m}$.y. with the accumulation of limestone (Unit II) at this site. This is a very high rate, which may be partly explained by the presence of redeposited material.

Following the early Cenomanian, there is a $15-\mathrm{m} . \mathrm{y}$. hiatus spanning the interval from the lower Cenomanian to the Santonian. Santonian rates are approximately $10 \mathrm{~m} / \mathrm{m}$.y. A hiatus of nearly $4 \mathrm{~m} . \mathrm{y}$. then precedes the late Campanian, when rates were very high (about 40 $\mathrm{m} / \mathrm{m} . \mathrm{y}$.), which is reminiscent of the high rates in the Albian, and similar to the rate for the Maastrichtian to late Campanian $(52 \mathrm{~m} / \mathrm{m} . \mathrm{y} . ; 42 \mathrm{~m} / \mathrm{m}$.y. for the Maastrichtian alone) at Site 463 .

Upper Maastrichtian was recovered in both Holes 465 and $465 \mathrm{~A}$. Rates calculated for both holes are slightly higher than for the lower Maastrichtian; for Hole 465 , the obtained rates are about $20 \mathrm{~m} / \mathrm{m}$.y. and $16 \mathrm{~m} / \mathrm{m}$.y., respectively. In the early Paleocene (Zones P1 and P2), sedimentation rates are lower than during the late Maastrichtian, reaching only $4 \mathrm{~m} / \mathrm{m}$.y. for Hole 465. Late Paleocene sedimentation rates are again somewhat higher, nearly reaching $8 \mathrm{~m} / \mathrm{m}$.y.

After the Paleocene, there is a hiatus of nearly 50 m.y. Sediments after the hiatus consist of a highly mixed zone containing Eocene fossils mixed with in situ sediments of early Pliocene age. By Section 3 of Core 2, normal continuous sedimentation of Pliocene fossils is recorded, the rate of sedimentation for the early Pliocene through Pleistocene is $1 \mathrm{~m} / \mathrm{m}$.y. However, the late Pleistocene is probably missing, so the rate is somewhat higher. 


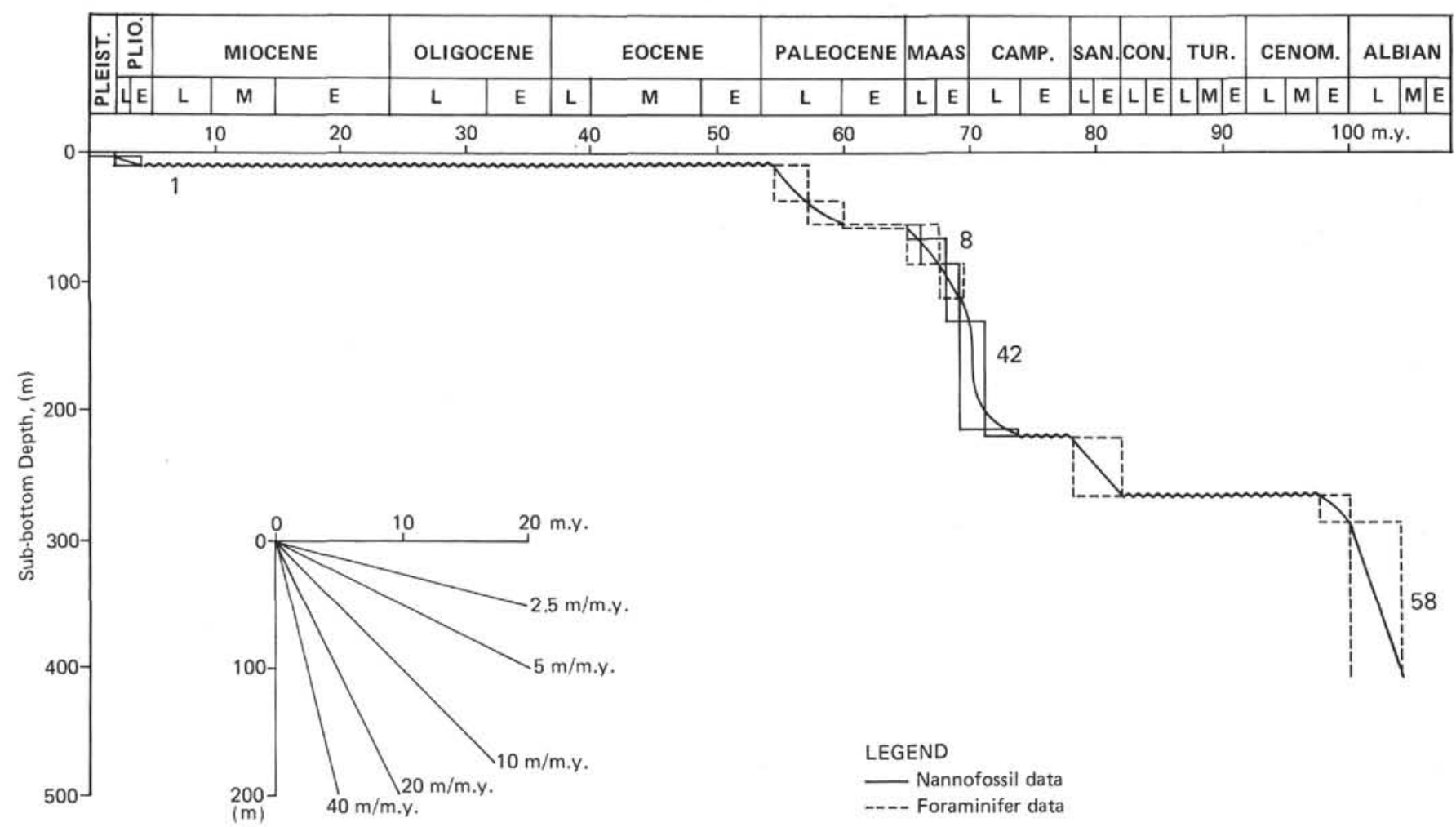

Figure 20. Sedimentation-rate curve for Site 465 .

Table 4. Sedimentation rates at Site 465 .

\begin{tabular}{|c|c|c|c|c|}
\hline Age & $\begin{array}{l}\text { Sub-bottom } \\
\text { Depth } \\
\text { (m) }\end{array}$ & $\begin{array}{l}\text { Thickness } \\
\text { (m) }\end{array}$ & $\begin{array}{l}\text { Time } \\
(\mathrm{m} . \mathrm{y} .)\end{array}$ & $\begin{array}{c}\text { Average } \\
\text { Rate } \\
\text { (m/m.y.) }\end{array}$ \\
\hline \multicolumn{5}{|l|}{ Hole 465} \\
\hline Late Paleocene & $10.5-48.5$ & 38 & $54.5-59$ & 8 \\
\hline Early Paleocene & $48.5-67.5$ & 19 & $60-65$ & 4 \\
\hline Late Maastrichtian & $67.5-96$ & 28.5 & $65-69$ & 7 \\
\hline \multicolumn{5}{|l|}{ Hole 465A } \\
\hline $\begin{array}{l}\text { Paleocene } \\
\text { (P4-G. eugubina) }\end{array}$ & $39-62$ & 23 & $57-65$ & 3 \\
\hline Late Maastrichtian & $62-86.5$ & 24 & $65-68$ & 8 \\
\hline $\begin{array}{l}\text { Early Maastrichtian to } \\
\text { late Campanian }\end{array}$ & $134-219.5$ & 85.5 & $69-71$ & 42 \\
\hline $\begin{array}{l}\text { Early Santonian to } \\
\text { late Coniacian }\end{array}$ & $250-276.5$ & 26.5 & $80-84$ & 7 \\
\hline $\begin{array}{l}\text { Early Cenomanian to } \\
\text { late Albian }\end{array}$ & $276.5-411$ & 134.5 & $99-102$ & 45 \\
\hline Late Albian & $295.5-411$ & 115.5 & $100-102$ & 58 \\
\hline
\end{tabular}

According to the conclusions of Lancelot and Larson (1975), it is possible to reconstruct the movement of Leg 32 sites by taking into account Pacific Plate motions and magnetic anomalies. Following their assumptions, Sites 465 would have crossed the Equator just after 90 m.y. ago. Table 5 depicts the approximate latitudes versus age of Site 465 , according to this model. These authors suggest that two of the criteria indicating that a site has crossed into the equatorial high-productivity zone are high sedimentation rates and(or) increased abundance of radiolarians. At Site 465 , the highest sedimentation rates occurred 100 m.y. ago, when the site theoretically had just crossed into the high-productivity area; radiolarians are abundant in sediments of this age.
Table 5. Proposed latitudes of Site 465 and sediment characteristics.

\begin{tabular}{cccc}
\hline $\begin{array}{c}\text { Age } \\
\text { (m.y.) }\end{array}$ & $\begin{array}{c}\text { Latitude } \\
\text { (Lancelot-Larson } \\
\text { model, Leg 32) }\end{array}$ & $\begin{array}{c}\text { Accumulation } \\
\text { Rate } \\
\text { (m/m.y.) }\end{array}$ & $\begin{array}{c}\text { Radiolarian } \\
\text { Zone }\end{array}$ \\
\hline 60 & $16^{\circ} \mathrm{N}$ & 4 & - \\
70 & $11-12^{\circ} \mathrm{N}$ & 42 & - \\
80 & $6^{\circ} \mathrm{N}$ & 7 & A. urna \\
90 & $1^{\circ} \mathrm{N}$ & (hiatus) & - \\
100 & $4^{\circ} \mathrm{S}$ & 58 & D. somphedia \\
\hline
\end{tabular}

At 90 m.y., when this site is supposed to have been just at the Equator, there is a hiatus in the sedimentary succession. At $80 \mathrm{~m} . \mathrm{y}$., the site is supposed to have passed out of the high-productivity zone; radiolarians are again preserved at this site. The sedimentation rates at this time were significantly lower, however, because of a hiatus before and age uncertainties after this interval. For this reason, the rate of $7 \mathrm{~m} / \mathrm{m}$.y. is only an approximate.

At $70 \mathrm{~m} . \mathrm{y}$. accumulation rates were again very high; the site supposedly was at $12^{\circ} \mathrm{N}$. It is possible, as suggested earlier, that this was a time of high oceanic fertility. At 60 m.y., in the early Paleocene, the sedimentation rate was relatively low, while the site is assumed to have been close to $16^{\circ} \mathrm{N}$.

\section{SUMMARY AND CONCLUSIONS}

The volcanic, tectonic, and depositional histories of Site 465 on southern Hess Rise can be interpreted from the 476-meter cored interval. The site is in 2161 meters 
of water just north of Mellish Bank, near the center of a small, apparently fault-bounded basin. Plans were to sample a calcareous section that had been above the CCD for its entire history, and to sample the underlying igneous basement.

\section{Basement Rocks and Physical Properties}

Deeply weathered trachyte and calcite-cemented trachyte breccia underlie the sediment sequence at Site 465. Trachyte breccia makes up the upper 17 meters, and the remaining 47 meters are trachyte flows. Based on vesicle and grain-size changes, the sequence was divided into 30 layers, which subsequently were placed in five groups (Seifert et al, this volume). Many of the layers represent individual flows, but in no place was a complete flow unit recovered; apparently, the finegrained and clay-rich flow boundaries were washed out during coring. No glassy flow margins occur in the recovered sequence. Vesicles are abundant and range from submicroscopic to more than $5 \mathrm{~mm}$ in diameter. Many are filled with calcite and smectite. Although most specimens are gray, the slight red coloration of some pieces indicates a low degree of oxidation. Pyrite is a common vein mineral, and barite was observed in one vein. The fragments increase in angularity with depth and the amount of fracturing decreases. The cause of brecciation is unknown, but it probably occurred in situ, and may have been caused by the explosive release of trapped gas. The trachyte breccia is cemented together mostly by calcite.

Petrographic studies reveal mostly trachytic textures. Pervasive alteration has affected the original mineralogy, so that only a few of the primary minerals remain. The original minerals were plagioclase, possible pyroxene, and iron-ore microphenocrysts, set in a groundmass of glass, iron-ore minerals, and feldspar microlites. The present minerals include plagioclase as phenocrysts, laths, and microlites; mafic-mineral pseudomorphs; and iron-ore minerals; set in a groundmass of smectite and calcite.

The igneous rocks are altered trachyte with nearly $60 \% \mathrm{SiO}_{2}$ and high percentages of $\mathrm{Na}_{2} \mathrm{O}$ and $\mathrm{K}_{2} \mathrm{O}$. We believe that these rocks are differentiated products of alkali basalt magma and probably are the result of oceanic-island or seamount volcanism. The large vesicles and the lack of glassy flow margins suggest that the eruptions occurred either subaerially or in very shallow water. Rounded volcanic clasts and the presence of several ash or volcanic sandstone beds in immediately overlying sediments indicate that a volcanic source was nearby after sedimentation began, implying that the site also may have been above sea level at some time in its history. Undoubtedly, parts of Hess Rise were above sea level during the early stages of its growth, which further suggests that it may have been a landmass of significant size, or at least a large archipelago before late Albian sediment deposition began.

Variations in magnetic intensity, susceptibility, and Curie temperature indicate that trachyte Units 1 and 2 are highly oxidized and have been completely remagnetized. In addition, it is possible that low-titanium titanomagnetites and(or) large magnetic-grain sizes may characterize the center of Unit 3. Paleolatitude estimates indicate that the site was near the Equator during formation of the trachytes. The measured velocities of sediment and rock samples agree well with those calculated from the seismic-reflection profiles. Unit 1, nannofossil ooze and chert, has a mean velocity of about $1.58 \mathrm{~km} / \mathrm{s}$. Unit 2, the olive laminated limestone, has a mean value of about $2.89 \mathrm{~km} / \mathrm{s}$. The trachyte of Unit 3 has a low velocity compared to that of oceanic basalts, averaging about $3.60 \mathrm{~km} / \mathrm{s}$. The low velocity for the trachyte is caused in part by its intense alteration. Heatflow measurements were attempted at four depths in Holes 465 and 465A. A value of $1.36 \mathrm{HFU}$ was calculated for Hess Rise, which is similar to North Pacific averaged data for crust $100 \mathrm{~m} . \mathrm{y}$. old, indicating that Hess Rise is thermally extinct.

\section{Hiatuses}

Evidence from the igneous rocks, which were extruded in shallow water or even subaerially, and from the shallow-water fossils in the immediately overlying sediments, indicates that the deposits recovered at Site 465 are from a depositional environment which has been deepening from close to the sea surface in late Albian time to more than $2 \mathrm{~km}$ water depth today. However, the continuously cored sediments (Fig. 21) have major hiatuses which represent approximately $75 \%$ of the time elapsed between the deposition of the oldest limestone and the thin veneer of Plio-Pleistocene deposits close to the sea floor at Site 465 . The sediments which document the remaining 25 to $30 \mathrm{~m} . \mathrm{y}$. therefore offer relatively short and discontinuous records of the depositional regime at this site. The major hiatuses span the time from early Cenomanian to Santonian, from Santonian to late Campanian (exact time span unknown), and from late Paleocene to early Pliocene. It is also unknown whether the oldest sediments overlie nearly penecontemporaneous volcanic rocks, or if the volcanic rocks are much older. If older, how many years elapsed between the eruptions of the volcanic rocks and the initiation of sedimentation? The highly altered state of the volcanic rocks suggests that they have been exposed to weathering for a considerable time.

Naturally, it is impossible to known how much and what kind of sediments were deposited during the intervals now. represented by hiatuses; however, the differences in lithology and the degree of lithification and diagenesis between Lithologic Units II and I (separated by the early Cenomanian to Santonian hiatus) suggest that a thick sedimentary sequence once was laid down at Site 465 and subsequently was eroded.

\section{Biostratigraphy}

Nannofossils and planktonic foraminifers occur throughout the entire sedimentary column at Site 465 , whereas benthic foraminifers seem to be lacking in the deepest sediment cores, of Albian age. Rare radiolarians are restricted to Cretaceous and Pleistocene deposits; diatoms were not found. The youngest sediment interval above the late Paleocene to early Pliocene hiatus 

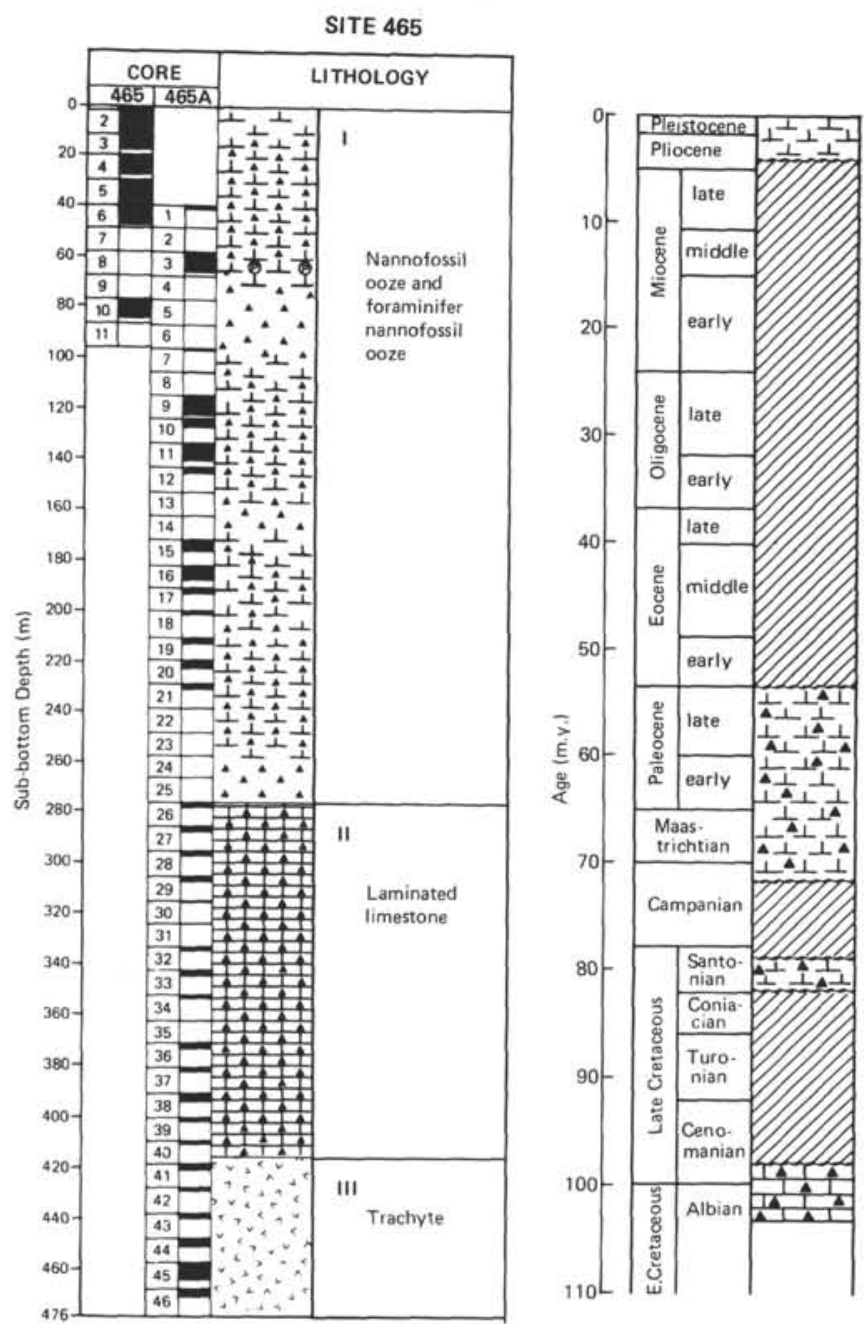

Figure 21. Stratigraphic column and major lacunas, Site 465.

comprises Pliocene and lower Pleistocene nannofossil oozes (upper Pleistocene deposits were not recovered at Site 465), which are mixed with Eocene and Paleocene sediments.

The late Albian to late Paleocene part of the column at Site 465 comprises two of the hiatuses discussed above, but it also encompasses some uniquely well-preserved parts of the stratigraphic column which only rarely have been sampled in the history of DSDP. An outstanding accomplishment at Site 465 is the apparently complete recovery of sediments documenting the transition from Cretaceous to Tertiary. A part of Core 465A-3 more than $100 \mathrm{~cm}$ thick, nannofossil ooze with uniquely well-preserved fossil faunas and floras, belongs to the basal Tertiary G. eugubina Zone (Boersma, this volume).

Although several horizons of extensive dissolution were observed, and although recrystallization and etching of calcareous fossils increase down-core, nannofossils from the Lower to Upper Cretaceous sediments are usually moderately well preserved, allowing a very detailed biostratigraphic zonation. Radiolarians were observed only in discrete horizons in Upper Cretaceous deposits, and most may be redeposited.
It is not possible to construct a reversal stratigraphy for Hole $465 \mathrm{~A}$, because magnetic inclinations in both the limestones and the trachytes are very low.

\section{Lithostratigraphy}

The biostratigraphic framework for Site 465 allows us to date the deposition of the major lithologic units (Fig. 20). A site-summary chart (Fig. 22) gives physical and chemical data. The sedimentary section was deposited during four relatively short intervals spread over more than 100 m.y.; only $25 \%$ of this time is actually represented in the sedimentary column. It is somewhat surprising, therefore, that the deposits are so remarkably uniform. Because of their uniformity, the sediments were grouped into only two lithologic units.

The older Unit II overlies altered trachyte of the volcanic basement (Unit III) and consists of olive-gray laminated limestone of late Albian to early Cenomanian age. The limestone consists dominantly of pelagic components mixed with a small proportion of clay. Most calcareous fossils are recrystallized and(or) etched, whereas radiolarians have been almost entirely replaced by $\mathrm{CaCO}_{3}$; their silica probably migrated into the chert. Outstanding features of these limestones $(>130 \mathrm{~m}$ thick) are the relatively high organic-carbon content and the laminations. Gray, fine-grained limestones occur in beds throughout this unit, their lower sharp and upper gradational boundaries with the olive-gray limestones suggest that they contain displaced material. Clear indications of current activity, such as truncated ripple laminations, were observed at several places throughout this unit, but horizons with graded bedding were observed only in the top and bottom parts. The difference in composition, degree of compaction, and diagenesis between Unit II and the overlying Unit I is so striking that it is assumed that a thick sediment pile, later eroded, was deposited during early Cenomanian to Santonian time.

The thick Santonian to Pleistocene soupy to stiff nannofossil and foraminifer nannofossil oozes of Unit I are very homogeneous, but usually moderately to highly disturbed because chert was a common component in all cores except the most topmost one. The only macrofossils in the oozes are large Inoceramus fragments in the upper Campanian to lower Maastrichtian.

\section{Depositional History}

The planktonic faunas and floras in Site 465 sediments have changed in a very specific manner as the site moved northward from a probable location just south of the equator under tropical surface-water masses during mid-Cretaceous time to its present location under temperate to subtropical, oligotrophic central North Pacific surface waters. The Cretaceous and Paleocene planktonic foraminifers are therefore typical of tropical surface-water masses, whereas the faunas of the Pleistocene sediments resemble those of Site 310 , farther to the north, except that the Site 465 faunas contain fewer $G$. pachyderma.

Besides their tropical planktonic-foraminifer faunas, the olive-gray Albian to Santonian laminated limestones 

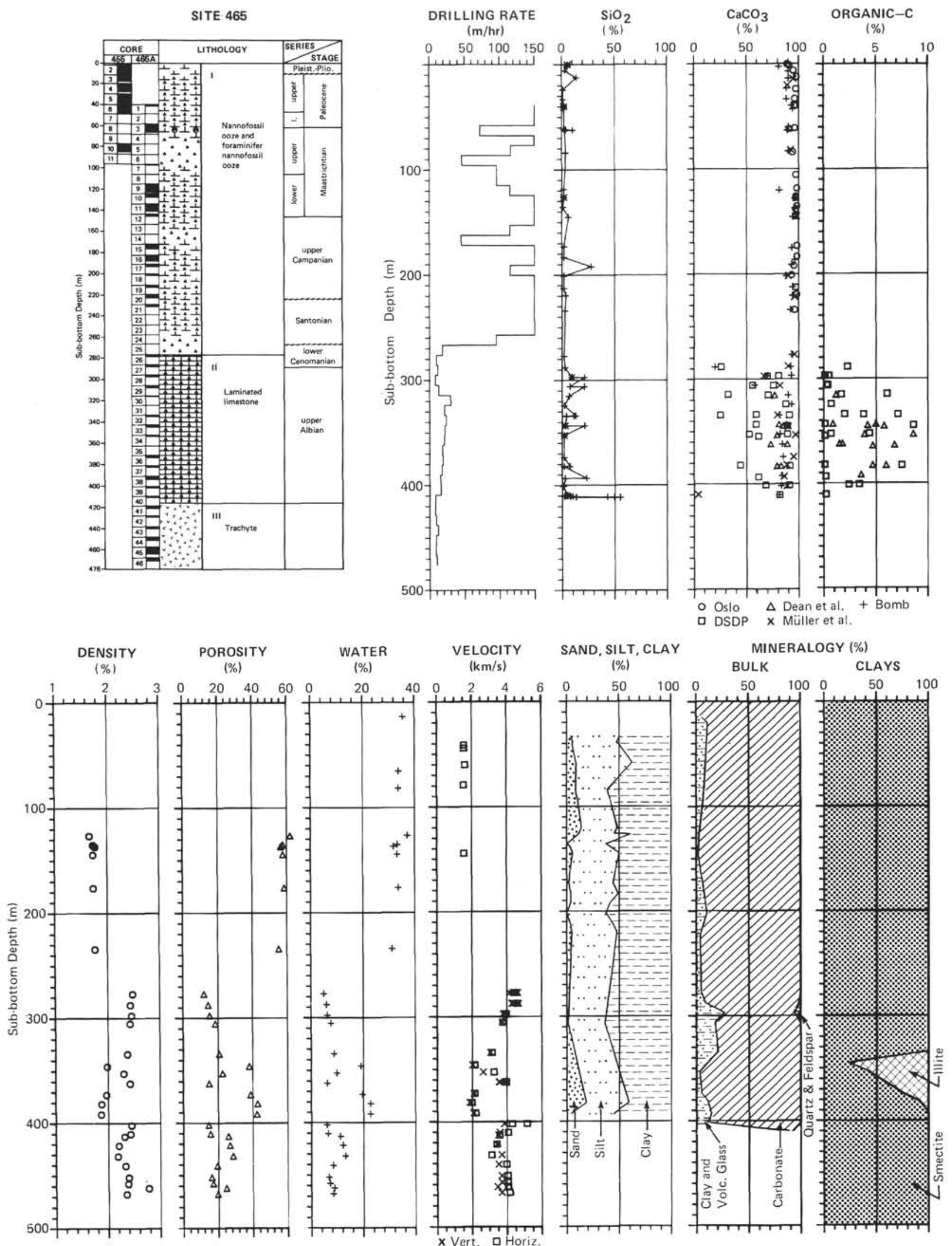

Figure 22. Site-summary chart, Site 465 , southern Hess Rise. The data for the summary are compiled from the following sources: $\% \mathrm{CaCO}_{3}$ and $\%$ organic carbon from Dean (this volume); density, $\%$ porosity, water content (\% water), and sound velocity from Appendix D (this chapter) and Fujii (this volume); \% sand, silt, and clay from Appendix E (this chapter); and clay mineralogy from Appendix C (this chapter) and Nagel and Schumann (this volume). 
of Unit II display many features characteristic of sediment deposited in relatively shallow water (a few hundreds of meters), beneath the fertile equatorial-current regime. Although many of the features can be attributed to distal turbidite sedimentation, the coincidence of laminated sediments, high organic-carbon contents (possibly in part terrigenous), an oxygen-poor depositional environment as indicated by the benthic foraminifers, high concentrations of radiolarians, and high bulk sedimentation rates seem to indicate very fertile surfacewater masses of the equatorial-current regime. It is interesting to note that the time of the Equator crossing (applying the model of Lancelot and Larson, 1975) coincides with the Cenomanian to Coniacian hiatus, when southern Hess Rise was a fairly shallow and possibly large feature, which might have caused significant disturbances of the equatorial-current regime.

Important chemical and physical changes of the surface water during the global crises at the end of the Mesozoic are indicated by the very small lowermost Paleocene planktonic-foraminifer faunas and anomalous nannofossil floras. The apparently complete recovery of the Upper Cretaceous and lower Tertiary interval allows a detailed assessment of changes in the surface waters and bottom waters (Boersma and Shackleton, this volume).

Changes in the depositional environment under the influence of the bottom-water masses are much more difficult to assess, because it is obvious that the depth of deposition has changed from a few hundreds of meters during mid-Cretaceous time to more than $2 \mathrm{~km}$ in modern times. It is therefore difficult to tell whether changes were caused only by subsidence, or if they were caused by small changes of the bottom-water hydrography. We have no indications that the water depth at this site was ever greater than it is today, but it probably was always shallower. The subsidence of the site can be interpreted through geophysical data and evidence from the Site 465 samples. The trachytic rocks underlying the older sediments were extruded either subaerially or in shallow water. Mollusk fragments and the oldest benthic foraminifers in sediments which overlie cross-laminated ash beds on top of the trachyte indicate a deposition depth of a few hundreds of meters during Albian time, then rapid subsidence to lower bathyal depth.

The composition of the benthic-foraminifer faunas and the laminated nature of Unit II point to oxygenpoor (mid-water oxygen minimum) conditions close to the sediment/water interface. However, despite this fact, Unit II, which was deposited in a few hundreds of meters of water, also displays sedimentary structures in- dicating at least some bottom-current activity (graded beds, ripple marks, clastic limestones with basalt pebbles, reworked material, size sorting of radiolarians, etc.).

At present, it is not clear what hydrographic events were responsible for the presence of the three important hiatuses, and for the discontinuous occurrence of reworked sediment components (particularly in the upper Maastrichtian, upper Campanian, and upper Albian to lower Cenomanian). On the other hand, an apparently complete sedimentary sequence across the Cretaceous/ Tertiary boundary was recovered.

The site apparently has remained well above the CCD since mid-Cretaceous time, and the sediment sequence represents a record of normal pelagic carbonate deposition. However, despite the relatively shallow water, horizons of intense dissolution occur at irregular intervals. We do not understand what hydrographic or chemical changes near the benthic boundary layer are able to drastically change the dissolution rate of calcareous particles. Although similar observations have been made at Site 463, and at other DSDP sites, it is unknown whether these dissolution events are local phenomena, or if they can be correlated across the entire ocean.

\section{REFERENCES}

Chase, T. E., Menard, H. W., and Mammerickx, J., 1971. Topography of the North Pacific: La Jolla (Univ. Calif.).

Lancelot, Y., 1978. Relations entre evolution sedimentaire et tectonique de la Plaque Pacifique depuis la Cretace Inferieur. Mem. Soc. Geol. France, 134.

Lancelot, Y., and Larson, R. L., 1975. Sedimentary and tectonic evolution of the northwestern Pacific. In Larson, R. L., Moberly, R., et al., Init. Repts. DSDP, 32: Washington (U.S. Govt. Printing Office), 925-939.

Larson, R. L., Lancelot, Y., Gardner, J. V., et al., 1975. Magnetic, bathymetric, seismic reflection, and positioning data collected underway on Glomar Challenger, Leg 32. In Larson, R. L., Moberly, R., et al., Init. Repts. DSDP, 32: Washington (U.S. Govt. Printing Office), 393-427.

Larson, R. L., Moberly, R., et al., 1975. Site 310: Hess Rise. In Larson, R. L., Moberly, R., et al., Init. Repts. DSDP, 32: Washington (U.S. Govt. Printing Office), 233-293.

Thierstein, H., 1973. Lower Cretaceous calcareous nannoplankton biostratigraphy. Abh. Geol. Bundesanst. Wien, 64:1-52.

Uyeda, S., and Horai, K., in press. Heat flow measurements, DSDP Leg 60. In Hussong, D., Uyeda, S., et al., Init. Repts. DSDP, 60: Washington (U.S. Govt. Printing Office).

Vincent, E., 1975. Neogene planktonic foraminifers from the central North Pacific, Leg 32, DSDP. In Larson, R. L., Moberly, R., et al., Init. Repts. DSDP, 32: Washington (U.S. Govt. Printing Office), $765-801$.

Yokota, T. H., Kinoshita, H., and Uyeda, S., 1980. New DSDP downhole temperature probe utilizing digital off-line recording system with IC RAM elements. Bull. Earthquake Res. Inst., 55:75-88. 
APPENDIX A

Smear-Slide Summary, Site $\mathbf{4 6 5}$

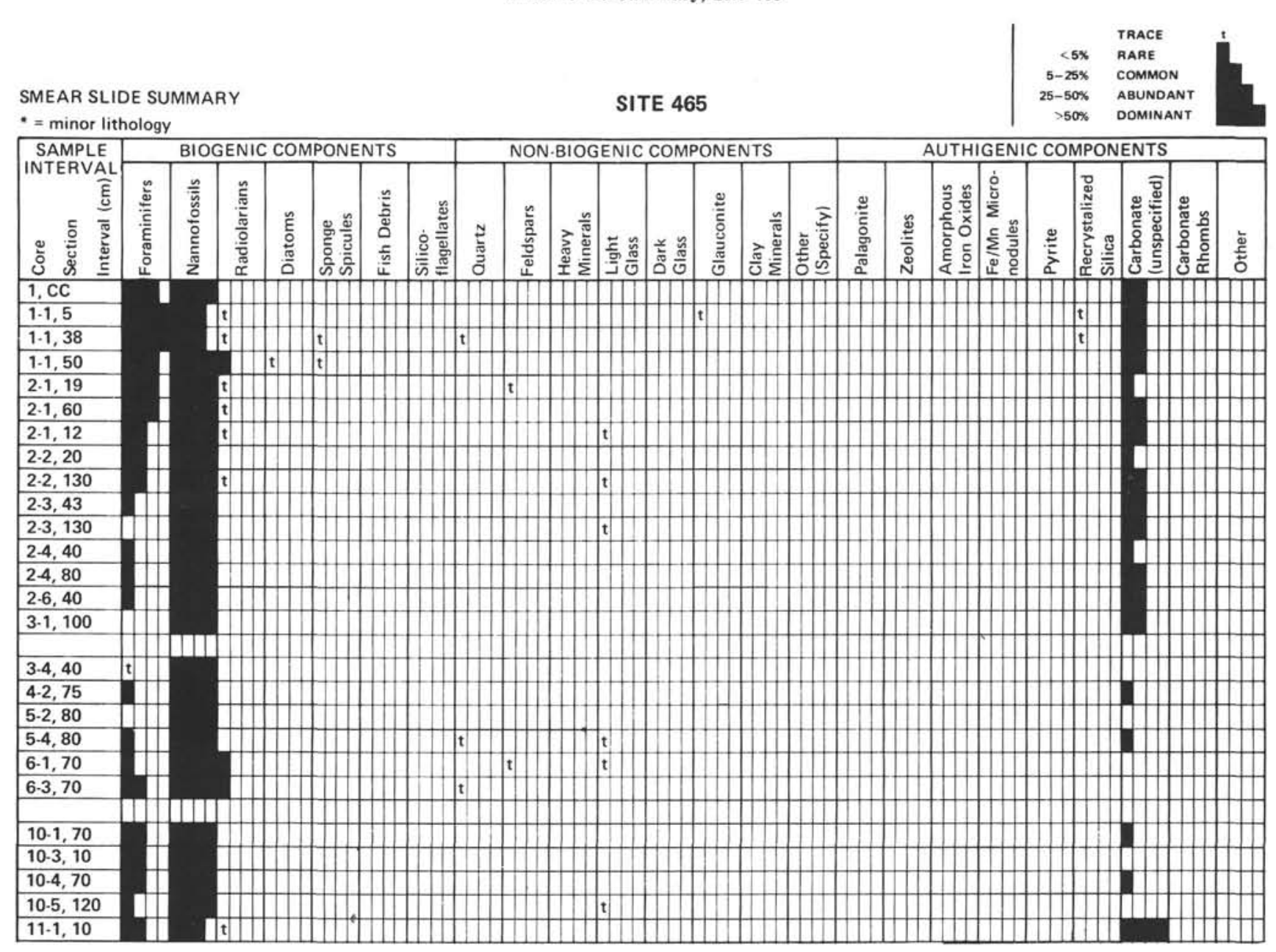


Appendix A. (Continued).

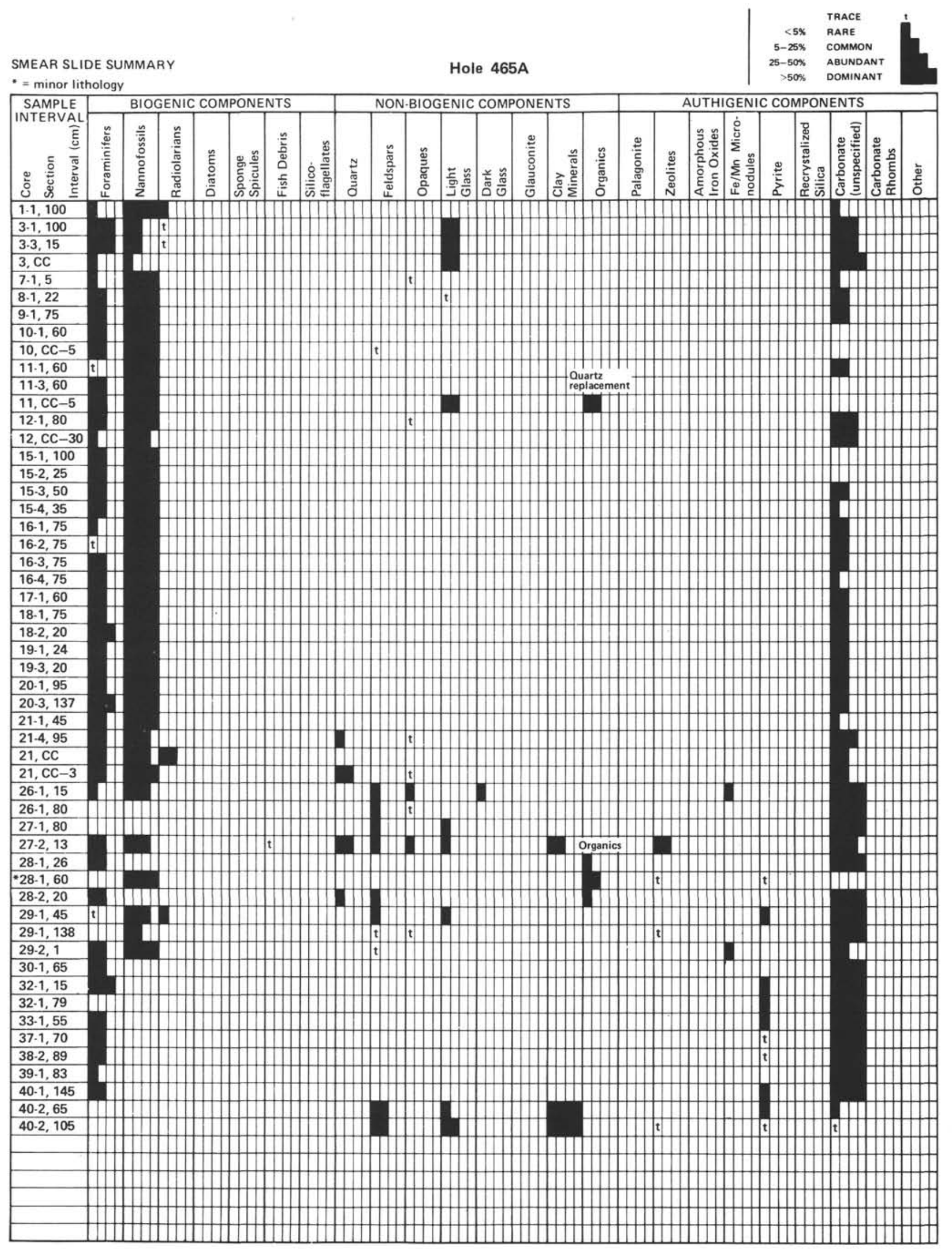


Appendix A. (Continued).

Hole 465-465A

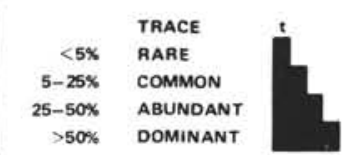

- = minor lithology

ENIC COMPONENTS

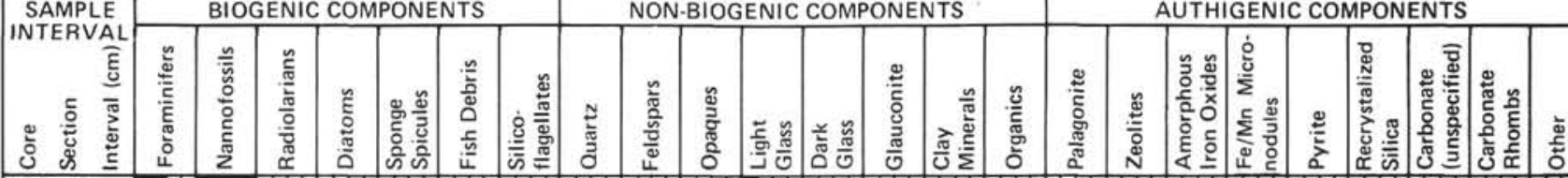

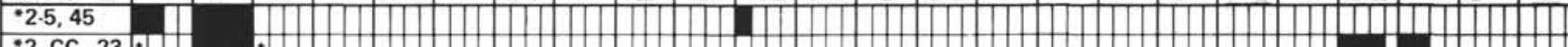

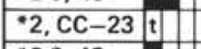

$* 2 \cdot 3,43$

*3-1, 5

*4-1, 51

*4-2, 117

\begin{tabular}{|l|l|l}
$* * 11$, CC & & \\
\hline & &
\end{tabular}

t $t$ t

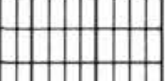

*3-3, 143

*3-4, 25

*8, CC -8

$+17-2,25$

*21-4, 25

+27-2, 65

*28-1, 60

* $30-1,20$

*31-1, 22

*33-1, 30

*37-1, 125

*37-2, 82

-40-1, $115 \mathrm{t}$

$* 40-1.139$

APPENDIX B

Bulk Mineralogy and Clay Mineralogy, Site 465

\begin{tabular}{|c|c|c|c|c|c|c|c|c|c|c|c|c|c|c|c|c|c|}
\hline \multirow[b]{2}{*}{ Core } & \multirow[b]{2}{*}{ Section } & \multirow[b]{2}{*}{$\begin{array}{l}\text { Interval } \\
(\mathrm{cm})\end{array}$} & \multirow[b]{2}{*}{ Sample } & \multirow{2}{*}{$\begin{array}{l}\text { Sub-bottom } \\
\text { Depth } \\
\text { (m) }\end{array}$} & \multirow[b]{2}{*}{$\begin{array}{l}\text { Clay Minerals } \\
+ \text { Volcanic Glass }\end{array}$} & \multicolumn{5}{|c|}{ Bulk Mineralogy $(\%)$} & \multirow[b]{2}{*}{$\begin{array}{l}\text { Clinoptil- } \\
\text { olite }\end{array}$} & \multirow[b]{2}{*}{ Others } & \multicolumn{5}{|c|}{ Clay Mineralogy $(\%)$} \\
\hline & & & & & & Quartz & Feldspar & Carbonates & Opal-CT & Pyrite & & & Smectite & Illite & Chlorite & Kaolinite & Others \\
\hline \multicolumn{18}{|c|}{ Hole 465} \\
\hline 3 & 3 & $108-110$ & 1 & 14.59 & 5.1 & - & - & 94.9 & & - & Tr. & & 100 & - & & & CPT \\
\hline 4 & 1 & $49-50$ & 2 & 20.49 & 10.9 & - & - & 89.1 & & - & - & & - & - & & & - \\
\hline 10 & 4 & $20-22$ & 3 & 81.71 & 7.7 & - & - & 92.3 & & - & Tr. & & - & - & & & CPT \\
\hline \multicolumn{18}{|c|}{ Hole 465A } \\
\hline 10 & 3 & $34-36$ & 1 & 127.85 & 2.6 & - & - & 97.4 & & - & Tr. & & - & - & & & CPT \\
\hline 12 & 2 & $5-7$ & 2 & 145.06 & 1.9 & - & - & 98.1 & & - & Tr. & & - & - & & & CPT \\
\hline 18 & 2 & $4-6$ & 3 & 202.05 & 10.3 & - & - & 89.7 & & - & - & & 100 & - & & & - \\
\hline 20 & 2 & $104-106$ & 4 & 222.05 & 3.9 & - & - & 96.1 & & - & Tr. & & - & - & & & CPT \\
\hline 26 & 1 & $18-19$ & 5 & 276.68 & 4.5 & - & - & 95.5 & & - & - & & 100 & - & & & - \\
\hline 27 & 2 & $24-25$ & 6 & 287.74 & 8.7 & - & -1.5 & 89.7 & & - & - & & 100 & - & & & - \\
\hline 28 & 2 & $7-8$ & 7 & 297.07 & 27.0 & - & 6.4 & 66.6 & & 1.0 & - & & 100 & - & & & - \\
\hline 29 & 1 & $136-137$ & 8 & 306.36 & 18.0 & - & - & 82.0 & & - & - & & - & - & & & - \\
\hline 32 & i & $84-84$ & 9 & 334.36 & 20.5 & - & - & 79.5 & & - & - & & 100 & - & & & - \\
\hline 33 & 2 & $63-64$ & 10 & 345.13 & 10.3 & - & - & 89.7 & & - & - & & 23.7 & 76.3 & & & - \\
\hline 34 & $i$ & $80-81$ & 11 & 353.30 & 3.2 & - & - & 96.8 & & - & - & & 42.5 & 57.5 & & & - \\
\hline 36 & 2 & $112-113$ & 12 & 374.12 & 5.1 & - & - & 94.9 & & - & - & & 76.0 & 24 & & & - \\
\hline 37 & I & $29-30$ & 13 & 381.90 & 11.5 & - & - & 88.5 & & - & - & & 92.0 & 8.0 & & & - \\
\hline 38 & 2 & $84-85$ & 14 & 392.84 & 14.1 & - & - & 85.9 & & - & - & & 100 & - & & & - \\
\hline 39 & 2 & $36-37$ & 15 & 401.86 & 11.5 & - & - & 88.5 & & - & - & & - & - & & & - \\
\hline 40 & 1 & $42-43$ & 16 & 409.92 & 8818 & 1.6 & 3.0 & 3.8 & & 3.8 & - & & 100 & - & & & - \\
\hline
\end{tabular}


APPENDIX C

Physical-Property Measurements, Site 465 (Fujii, this volume)

\begin{tabular}{|c|c|c|c|c|c|c|c|c|c|c|c|c|}
\hline & & & Sub-bottom & & $\begin{array}{l}\text { city } \\
\text { /s) }\end{array}$ & & ape & & Gravi & netric & & $\begin{array}{c}\text { Mean } \\
\text { Wet-Bulk }\end{array}$ \\
\hline Core & Section & $\begin{array}{l}\text { Interval } \\
(\mathrm{cm})\end{array}$ & $\begin{array}{l}\text { Depth } \\
\text { (m) }\end{array}$ & Vert. & Horiz. & $\begin{array}{l}\text { Density } \\
\left(\mathrm{g} / \mathrm{cm}^{3}\right)\end{array}$ & $\begin{array}{c}\text { Porosity } \\
(\%)\end{array}$ & $\begin{array}{l}\text { W.C. } \\
(\%)\end{array}$ & $\begin{array}{c}\text { Porosity } \\
(\%)\end{array}$ & $\begin{array}{l}\text { Density } \\
\left(\mathrm{g} / \mathrm{cm}^{3}\right)\end{array}$ & $\underset{\left(\mathrm{g} / \mathrm{cm}^{3}\right)}{\text { G.D. }}$ & $\begin{array}{l}\text { Density } \\
\left(\mathrm{g} / \mathrm{cm}^{3}\right)\end{array}$ \\
\hline Hole & & & & & & & & & & & & \\
\hline 1 & 1 & $50-60$ & $0-1$ & & & 1.66 & 62.3 & & & & & \\
\hline & 1 & 55 & & & & 1.66 & 62.3 & & & & & \\
\hline 2 & 1 & $60-80$ & $1.0-10.5$ & & & 1.54 & 69.3 & & & & & \\
\hline & 2 & $60-90$ & & & & 1.50 & 71.9 & & & & & \\
\hline & 3 & $20-40$ & & & & 1.47 & 73.2 & & & & & \\
\hline & 4 & $50-70$ & & & & 1.51 & 70.6 & & & & & \\
\hline & 4 & 111 & & & & 1.55 & 68.7 & & & & & \\
\hline & 5 & $60-80$ & & & & 1.53 & 70.0 & & & & & \\
\hline 3 & I & $90-110$ & $10.5-20.0$ & & & 1.51 & 71.2 & & & & & \\
\hline & 2 & $60-90$ & & & & 1.50 & 71.9 & 36.8 & $(144-150)$ & & & \\
\hline & 3 & $50-100$ & & & & 1.54 & 69.3 & & & & & \\
\hline & 3 & 111 & & & & 1.55 & 68.7 & & & & & \\
\hline & 4 & $30-50$ & & & & 1.56 & 68.1 & & & & & \\
\hline 4 & 1 & $60-100$ & $20.0-29.5$ & & & 1.54 & 69.3 & & & & & \\
\hline & 2 & 74 & & & & & & & & & & \\
\hline & 3 & $50-100$ & & & & 1.57 & 67.4 & & & & & \\
\hline 5 & 1 & $60-90$ & $29.5-39.0$ & & & 1.52 & 70.6 & & & & & \\
\hline & 3 & 110 & & & & & & & & & & \\
\hline & 5 & $60-90$ & & & & 1.56 & 68.1 & & & & & \\
\hline 6 & 2 & $60-90$ & $39.0-48.5$ & & & 1.57 & 67.4 & & & & & \\
\hline & 2 & $75-78$ & & & 1.56 & 1.57 & 67.4 & & & & & \\
\hline & 2 & 83 & & & & 1.57 & 67.4 & & & & & \\
\hline & 4 & $60-90$ & & & & 1.58 & 66.8 & & & & & \\
\hline & 4 & $79-81$ & & & 1.58 & 1.58 & 66.8 & & & & & \\
\hline 10 & 2 & $60-90$ & $77.0-86.5$ & & & 1.54 & 69.3 & & & & & \\
\hline & 2 & $62-65$ & & & 1.55 & 1.54 & 69.3 & & & & & \\
\hline & 2 & 78 & & & & 1.54 & 69.3 & & & & & \\
\hline & 3 & $146-150$ & & & & & 35.0 & & & & & \\
\hline & 4 & $60-90$ & & & & 1.52 & 70.6 & & & & & \\
\hline & 5 & $50-80$ & & & & 1.54 & 69.3 & & & & & \\
\hline Hole & $65 \mathrm{~A}$ & & & & & & & & & & & \\
\hline 3 & 2 & $60-90$ & $58.0-67.5$ & & & 1.44 & 75.1 & & & & & \\
\hline & 2 & $63-65$ & & & 1.63 & 1.44 & 75.1 & & & & & \\
\hline & 2 & 89 & & & & 1.44 & 75.1 & & & & & \\
\hline & 4 & $60-90$ & & & & 1.57 & 67.4 & & & & & \\
\hline & 5 & $144-150$ & & & & & & 35.0 & & & & \\
\hline 10 & 2 & $40-60$ & $124.5-134.0$ & & & 1.55 & 62.7 & & & & & \\
\hline & 2 & $56-58$ & & & & 1.56 & 68.1 & 38.5 & 62.8 & 1.67 & 2.76 & \\
\hline & 2 & 105 & & & & 1.54 & 69.3 & & & & & \\
\hline & 3 & $30-40$ & & & & 1.51 & 71.2 & & & & & \\
\hline 11 & 1 & $125-127$ & $134.0-143.5$ & & & & & 34.5 & 58.4 & 1.74 & 2.73 & \\
\hline 11 & 2 & $40-80$ & & & & 1.61 & 64.9 & & & & & \\
\hline & 2 & $144-150$ & & & & 1.60 & 65.5 & 33.0 & 57.2 & 1.78 & 2.78 & \\
\hline & 3 & $40-70$ & & & & 1.61 & 64.9 & & & & & \\
\hline & 4 & $60-70$ & & & & 1.58 & 66.8 & & & & & \\
\hline & 4 & 53 & & & & 1.58 & 66.8 & & & & & \\
\hline & 4 & 71 & & & & 1.58 & 66.8 & & & & & \\
\hline 12 & 1 & $60-90$ & $143.5-153.0$ & & & 1.61 & 64.9 & & & & & \\
\hline & 1 & $110-112$ & & & & 1.59 & 66.2 & 34.5 & 58.5 & 1.74 & 2.74 & \\
\hline & 1 & 112 & & & & 1.59 & 66.2 & & & & & \\
\hline & 1 & $102-104$ & & & 1.56 & 1.59 & 66.2 & & & & & \\
\hline 15 & 1 & $60-90$ & $172.0-181.5$ & & & 1.61 & 64.9 & & & & & \\
\hline & 2 & $40-60$ & & & & 1.61 & 64.9 & & & & & \\
\hline & 3 & $144-150$ & & & & & & 34.8 & 59.1 & 1.74 & 2.77 & \\
\hline 16 & 1 & $60-90$ & $181.5-191.0$ & & & 1.58 & 66.8 & & & & & \\
\hline & 2 & $60-90$ & & & & 1.59 & 66.2 & & & & & \\
\hline & 3 & $60-90$ & & & & 1.62 & 64.2 & & & & & \\
\hline & 3 & 85 & & & & 1.62 & 64.2 & & & & & \\
\hline & 4 & $40-70$ & & & & 1.60 & 65.5 & & & & & \\
\hline 17 & 1 & $60-90$ & $191.0-200.5$ & & & 1.58 & 66.8 & & & & & \\
\hline & 1 & 40 & & & & 1.56 & 68.1 & & & & & \\
\hline 18 & 1 & $60-90$ & $200.5-210.0$ & & & 1.62 & 64.6 & & & & & \\
\hline 19 & 3 & $40-50$ & $210-219.5$ & & & 1.58 & 66.8 & & & & & \\
\hline 20 & 1 & $60-90$ & $219.5-229.0$ & & & 1.57 & 67.4 & & & & & \\
\hline 21 & 4 & $30-70$ & $229.0-238.5$ & & & 1.59 & 66.2 & & & & & \\
\hline & 4 & $88-96$ & & & & 1.65 & 63.0 & 32.4 & 55.9 & 1.77 & 2.72 & \\
\hline 26 & 1 & $68-70$ & $276.5-286.0$ & 4.40 & 4.48 & 2.52 & 10.7 & 5.02 & 12.2 & 2.48 & 2.68 & 2.50 \\
\hline 27 & 2 & 07 & $286.0-295.5$ & & & & & & & & & \\
\hline & & $11-13$ & & 4.32 & 4.60 & 2.57 & 8.1 & 6.2 & 14.7 & 2.44 & 2.68 & 2.51 \\
\hline 28 & 2 & 65 & $295.5-305.0$ & & & & & & & & & \\
\hline & & $64-66$ & & 3.82 & 3.95 & 2.54 & 9.8 & 6.5 & 15.5 & 2.46 & 2.73 & 2.50 \\
\hline 29 & 1 & 32 & $305.0-314.5$ & & & & & & & & & \\
\hline & & $33-35$ & & 3.73 & 3.77 & 2.48 & 13.0 & 7.9 & 18.8 & 2.43 & 2.76 & 2.46 \\
\hline 32 & 1 & 73 & $333.5-343.0$ & & & & & & & & & \\
\hline & & $74-76$ & & 3.05 & 3.28 & 2.31 & 23.6 & 9.1 & 21.0 & 2.37 & 2.73 & 2.34 \\
\hline 33 & 1 & $\begin{array}{l}49-61 \\
93-100\end{array}$ & $343.0-352.5$ & & & $\begin{array}{l}2.29 \\
2.27\end{array}$ & $\begin{array}{l}24.2 \text { (W) } \\
25.9 \text { (W) }\end{array}$ & & & & & \\
\hline & 2 & $\begin{array}{r}93-100 \\
133-150\end{array}$ & & & & $\begin{array}{l}2.27 \\
1.95\end{array}$ & 44.7 (W) & & & & & \\
\hline & & $140-142$ & & 2.03 & 2.15 & 2.04 & 39.3 & 19.9 & 38.5 & 1.99 & 2.59 & 2.02 \\
\hline 34 & 1 & $\begin{array}{c}1-3 \\
39-41\end{array}$ & $352.5-362.0$ & 2.64 & 3.27 & $\begin{array}{l}2.32 \\
2.19\end{array}$ & $\begin{array}{l}22.6 \\
30.6(\mathrm{~W})\end{array}$ & 10.2 & 22.9 & 2.31 & 2.68 & 2.32 \\
\hline & & $104-110$ & & & & 2.05 & 38.7 (W) & & & & & \\
\hline & 2 & $41-52$ & & & & 1.80 & 53.9 (W) & & & & & \\
\hline 35 & 1 & $6-12$ & $362.0-371.5$ & & & 2.32 & 22.8 (W) & & & & & \\
\hline & & $5-7$ & & 3.57 & 3.96 & 2.49 & 12.6 & 6.4 & 15.1 & 2.43 & 2.68 & 2.46 \\
\hline
\end{tabular}


Appendix C. (Continued).

\begin{tabular}{|c|c|c|c|c|c|c|c|c|c|c|c|c|c|c|c|}
\hline \multirow[b]{2}{*}{ Core } & \multirow[b]{2}{*}{ Section } & \multirow[b]{2}{*}{$\begin{array}{l}\text { Interval } \\
(\mathrm{cm})\end{array}$} & \multirow{2}{*}{$\begin{array}{l}\text { Sub-bottom } \\
\text { Depth } \\
\text { (m) }\end{array}$} & \multicolumn{2}{|c|}{$\begin{array}{l}\text { Velocity } \\
(\mathrm{km} / \mathrm{s})\end{array}$} & \multicolumn{2}{|c|}{ Grape } & \multicolumn{4}{|c|}{ Gravimetric } & \multirow{2}{*}{$\begin{array}{c}\text { Mean } \\
\text { Wet-Bulk } \\
\text { Density } \\
\left(\mathrm{g} / \mathrm{cm}^{3}\right)\end{array}$} & \multirow[b]{2}{*}{$\begin{array}{l}\text { Impedance } \\
10^{5} \mathrm{~g} / \mathrm{cm}^{3 / \mathrm{s}}\end{array}$} & \multirow{2}{*}{$\begin{array}{c}\text { Heat } \\
\text { Cond. } \\
\text { (R.T.) } \\
\left(\frac{\text { mcal }}{\mathrm{cm} \cdot \mathrm{c} \cdot{ }^{\circ} \mathrm{C}}\right)\end{array}$} & \multirow[b]{2}{*}{ Remarks } \\
\hline & & & & Vert. & Horiz. & $\begin{array}{l}\text { Density } \\
\left(\mathrm{g} / \mathrm{cm}^{3}\right)\end{array}$ & $\begin{array}{c}\text { Porosity } \\
(\%)\end{array}$ & $\begin{array}{l}\text { W.C. } \\
(\%)\end{array}$ & $\begin{array}{c}\text { Porosity } \\
(\%)\end{array}$ & $\begin{array}{l}\text { Density } \\
\left(\mathrm{g} / \mathrm{cm}^{3}\right)\end{array}$ & $\begin{array}{l}\text { G.D. } \\
\left(\mathrm{g} / \mathrm{cm}^{3}\right)\end{array}$ & & & & \\
\hline \multicolumn{16}{|c|}{ Hole 465A (Cont.) } \\
\hline \multirow[t]{2}{*}{35} & 1 & $31-33$ & & & & & & & & & & & & 5.40 & \\
\hline & & $38-46$ & & & & 2.47 & $14.0(\mathrm{~W})$ & & & & & & & & \\
\hline \multirow[t]{2}{*}{36} & 1 & $52-67$ & $371.5-381.0$ & & & 1.91 & $47.0(\mathrm{~W})$ & & & & & & & & \\
\hline & & $90-\mathrm{i} 01$ & & & & 1.83 & 51.9 (W) & & & & & & & & \\
\hline \multirow[t]{3}{*}{36} & 1 & $\begin{array}{c}132-134 \\
135\end{array}$ & $375.5-810.0$ & 2.11 & 2.15 & 1.96 & 43.9 & 20.5 & 39.4 & 1.97 & 2.59 & 1.97 & 4.16 & 371 & Limestone (olive-gray) \\
\hline & : & $0-22$ & & & & 1.81 & $53.1(\mathrm{~W})$ & & & & & & & 3.11 & \\
\hline & & $76-95$ & & & & 1.81 & 53.0 (W) & & & & & & & & \\
\hline \multirow[t]{7}{*}{37} & 1 & $30-37$ & $381.0-390.5$ & & & 1.84 & $51.2(\mathrm{~W})$ & & & & & & & & \\
\hline & & $52-54$ & & $(1.88)$ & (1.99) & 1.94 & 45.7 & 23.7 & 43.4 & 1.88 & 2.53 & 1.91 & 3.59 & & Limestone (olive-gray) \\
\hline & & $70-80$ & & & & 2.41 & $17.4(W)$ & & & & & & & & Limestone (olive gray) \\
\hline & & $126-134$ & & & & 2.35 & $20.8(W)$ & & & & & & & & Limestone (gray) \\
\hline & 2 & $0-7$ & & & & 2.36 & $20.6(W)$ & & & & & & & & \\
\hline & & $16-36$ & & & & 1.77 & $55.6(W)$ & & & & & & & & \\
\hline & & $64-70$ & & & & 2.26 & $26.2(\mathrm{~W})$ & & & & & & & & \\
\hline \multirow[t]{5}{*}{38} & 1 & $100-120$ & $390.5-400.0$ & & & 1.85 & $51.0(\mathrm{~W})$ & & & & & & & 3.32 & \\
\hline & & $105-107$ & & 2.09 & 2.20 & 1.88 & 48.8 & 23.5 & 42.8 & 1.87 & 2.49 & 1.88 & 3.93 & & Limestone (olive-gray) \\
\hline & & $44-58$ & & & & 1.82 & $52.3(\mathrm{~W})$ & & & & & & & & \\
\hline & 2 & $0-7$ & & & & 1.87 & 49.7 (W) & & & & & & & & \\
\hline & & $141-150$ & & & & 2.41 & $17.6(W)$ & & & & & & & & \\
\hline 39 & 1 & $53-60$ & $400.0-409.5$ & & & 2.39 & $18.3(W)$ & & & & & & & & \\
\hline & 1 & $118-124$ & & & & 1.91 & $47.2(W)$ & & & & & & & & \\
\hline & 2 & $24-27$ & & & 5.15 & & & & & & & & & & Chert (black) \\
\hline & & $45-53$ & & & & 2.42 & $16.7(W)$ & & & & & & & 4.02 & $\begin{array}{l}\text { Limestone } \\
\text { (light olive-gray) }\end{array}$ \\
\hline & & $45-47$ & & 3.85 & 4.29 & 2.53 & 10.3 & 6.1 & 14.7 & 2.45 & 2.69 & 2.49 & 9.59 & & $\begin{array}{l}\text { Limestone } \\
\text { (light olive-gray) }\end{array}$ \\
\hline & & $72-77$ & & & & 2.17 & $31.6(\mathrm{~W})$ & & & & & & & & $\begin{array}{l}\text { Limestone } \\
\text { (light olive-gray) }\end{array}$ \\
\hline 40 & 1 & $80-87$ & $409.5-419.0$ & & & 2.38 & $18.9(W)$ & & & & & & & & Limestone (olive gray) \\
\hline & & -85 & & 3.59 & 4.06 & 2.54 & 9.3 & 6.6 & 15.7 & 2.43 & 2.69 & 2.49 & 8.94 & & Limestone (olive gray) \\
\hline 40 & 1 & 100 & $409.5-419.0$ & & & & & & & & & & & 4.76 & $\begin{array}{l}\text { Limestone (olive-gray) } \\
\text { black lamination }\end{array}$ \\
\hline 40 & 2 & $15-21$ & & & & 1.98 & $43.1(W)^{\bullet}$ & & & & & & & & (Volcanic breccia) \\
\hline & & $23-35$ & & & & 2.24 & $27.6(W)^{*}$ & & & & & & & & \\
\hline & 3 & 35 & & & & & & & & & & & & 4.09 & \\
\hline 41 & 1 & 91-99 & $419.0-428.5$ & & & 2.27 & $32.0(\mathrm{~W})$ & & & & & & & & Trachyte \\
\hline & 2 & $103-109$ & & & & 2.18 & 36.7 (W) & & & & & & & 3.18 & Trachyte \\
\hline & & $108-110$ & & 3.43 & 3.41 & 2.22 & 34.7 & 12.6 & 27.2 & 2.20 & 2.64 & 2.21 & 7.58 & & Trachyte \\
\hline 42 & 3 & 24 & $428.5-438.0$ & & & & & & & & & & & 3.43 & \\
\hline & & $24-26$ & & 3.70 & 3.12 & 2.19 & 36.0 & 13.6 & 29.1 & 2.18 & 2.66 & 2.19 & 8.10 & & Trachyte \\
\hline 43 & 2 & $134-136$ & $438.0-447.5$ & 3.53 & 3.98 & 2.29 & 30.5 & 8.7 & 19.7 & 2.34 & 2.66 & 2.32 & 8.19 & & Trachyte \\
\hline 44 & 3 & 124 & $447.5-457.0$ & & & & & & & & & & & 3.37 & Trachyte \\
\hline & & $120-122$ & & 3.70 & 4.09 & 2.31 & 29.8 & 7.1 & 16.5 & 2.40 & 2.67 & 2.36 & 8.73 & & \\
\hline 45 & 1 & 81 & $457.0-466.5$ & & & & & & & & & & & 3.12 & Trachyte \\
\hline & & $83-85$ & & 3.73 & 4.06 & 2.33 & 28.5 & 7.5 & 17.4 & 2.39 & 2.67 & 2.36 & 8.80 & & Trachyte \\
\hline & 4 & 80 & & & & & & & & & & & & 3.24 & Trachyte \\
\hline & & $77-79$ & & 3.47 & 4.07 & 2.20 & 35.5 & 9.3 & 21.1 & 2.33 & 2.68 & 2.27 & 7.88 & & Trachyte \\
\hline 46 & 1 & 120 & $466.5-476.0$ & & & & & & & & & & & 3.21 & Trachyte \\
\hline & & $117-119$ & & 3.69 & 4.16 & 2.35 & 27.5 & 8.7 & 19.9 & 2.35 & 2.68 & 2.35 & 8.67 & & \\
\hline
\end{tabular}

Note: (W) whole core 2 minutes GRAPE; ${ }^{*}$ ) Grain density $\mathrm{eg}_{\mathrm{g}}=2.70 \mathrm{~g} / \mathrm{cc}$ is assumed, other basalt: $\mathrm{eg}_{\mathrm{g}}=2.85$. 
APPENDIX D

Coarse-Fraction ( $>62 \mu \mathrm{m}$ ) Components, Site 465

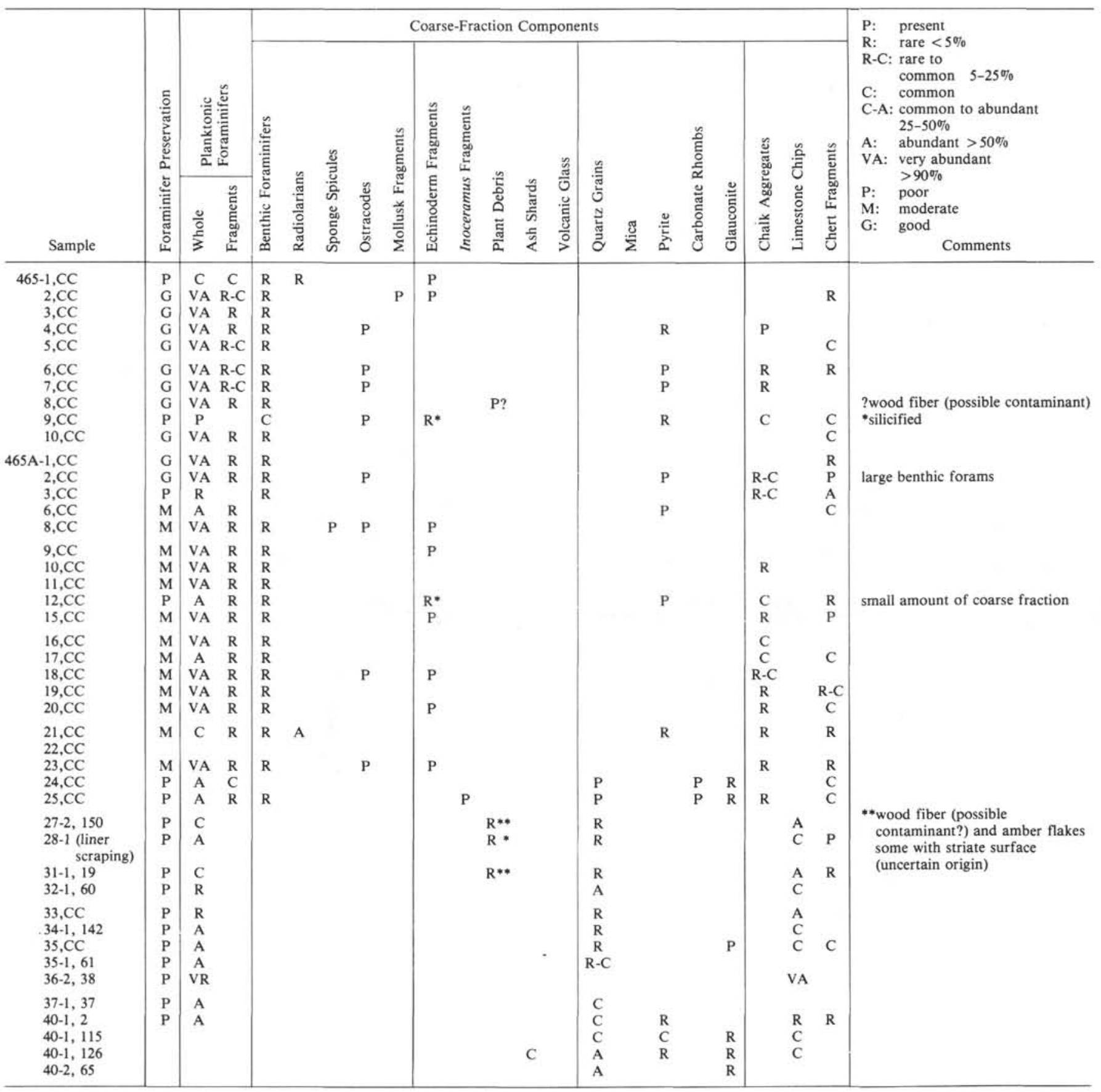


APPENDIX E

Grain-Size Analysis, Site 465

\begin{tabular}{|c|c|c|c|c|c|c|c|c|}
\hline Hole & Core & Section & $\begin{array}{c}\text { Interval } \\
(\mathrm{cm})\end{array}$ & $\begin{array}{l}\text { Sub-bottom } \\
\text { Depth } \\
\text { (m) }\end{array}$ & $\begin{array}{l}\text { Sand } \\
(\%)\end{array}$ & $\begin{array}{l}\text { Silt } \\
(\%)\end{array}$ & $\begin{array}{l}\text { Clay } \\
(\%)\end{array}$ & Classification \\
\hline 465 & 1 & 1 & 22.0 & 0.22 & 19.2 & 43.5 & 37.2 & Clayey silt \\
\hline 465 & 2 & 1 & 52.0 & 1.52 & 18.3 & 36.7 & 45.0 & Silty clay \\
\hline 465 & 2 & 4 & 52.0 & 6.02 & 3.4 & 65.4 & 31.2 & Clayey silt \\
\hline 465 & 3 & 2 & 77.0 & 12.77 & 1.4 & 62.3 & 36.3 & Clayey silt \\
\hline 465 & 4 & 3 & 106.0 & 24.06 & 5.9 & 52.7 & 41.3 & Clayey silt \\
\hline 465 & 5 & 3 & 75.0 & 33.25 & 4.0 & 46.4 & 49.6 & Silty clay \\
\hline 465 & 6 & 1 & 110.0 & 40.10 & 5.1 & 44.3 & 50.6 & Silty clay \\
\hline 465 & 10 & 5 & 110.0 & 84.10 & 9.0 & 29.9 & 61.2 & Silty clay \\
\hline $465 \mathrm{~A}$ & 1 & 1 & 30.0 & 39.30 & 6.0 & 41.6 & 52.4 & Silty clay \\
\hline $465 \mathrm{~A}$ & 3 & 1 & 50.0 & 58.50 & 9.0 & 53.6 & 37.3 & Clayey silt \\
\hline $465 \mathrm{~A}$ & 9 & 4 & 46.0 & 119.96 & 14.2 & 34.2 & 51.6 & Silty clay \\
\hline $465 \mathrm{~A}$ & 10 & 1 & 120.0 & 125.70 & 12.1 & 33.5 & 54.4 & Silty clay \\
\hline $465 \mathrm{~A}$ & 10 & 2 & 62.0 & 126.62 & 11.2 & 50.1 & 38.7 & Clayey silt \\
\hline $465 \mathrm{~A}$ & 11 & 2 & 30.0 & 135.80 & 0.3 & 37.1 & 62.6 & Silty clay \\
\hline $465 \mathrm{~A}$ & 11 & 4 & 30.0 & 138.80 & 3.4 & 38.7 & 57.9 & Silty clay \\
\hline $465 \mathrm{~A}$ & 12 & 1 & 100.0 & 144.50 & 5.7 & 44.5 & 49.8 & Silty clay \\
\hline $465 \mathrm{~A}$ & 15 & 1 & 90.0 & 172.90 & 1.7 & 42.4 & 55.9 & Silty clay \\
\hline $465 \mathrm{~A}$ & 16 & 2 & 37.0 & 183.37 & 3.8 & 45.3 & 50.9 & Silty clay \\
\hline $465 \mathrm{~A}$ & 17 & 1 & 120.0 & 192.20 & 3.7 & 37.6 & 58.7 & Silty clay \\
\hline $465 \mathrm{~A}$ & 18 & 1 & 111.0 & 201.61 & 0.2 & 37.3 & 62.5 & Silty clay \\
\hline $465 \mathrm{~A}$ & 19 & 2 & 103.0 & 212.53 & 3.7 & 40.9 & 55.4 & Silty clay \\
\hline $465 \mathrm{~A}$ & 20 & 1 & 22.0 & 219.72 & 4.9 & 43.2 & 51.9 & Silty clay \\
\hline $465 \mathrm{~A}$ & 29 & 1 & 137.0 & 306.37 & 1.2 & 35.1 & 63.7 & Silty clay \\
\hline $465 \mathrm{~A}$ & 37 & 1 & 104.0 & 382.04 & 18.7 & 40.6 & 40.8 & Silty clay \\
\hline $465 \mathrm{~A}$ & 38 & 2 & 83.0 & 392.83 & 3.7 & 40.6 & 55.7 & Silty clay \\
\hline
\end{tabular}



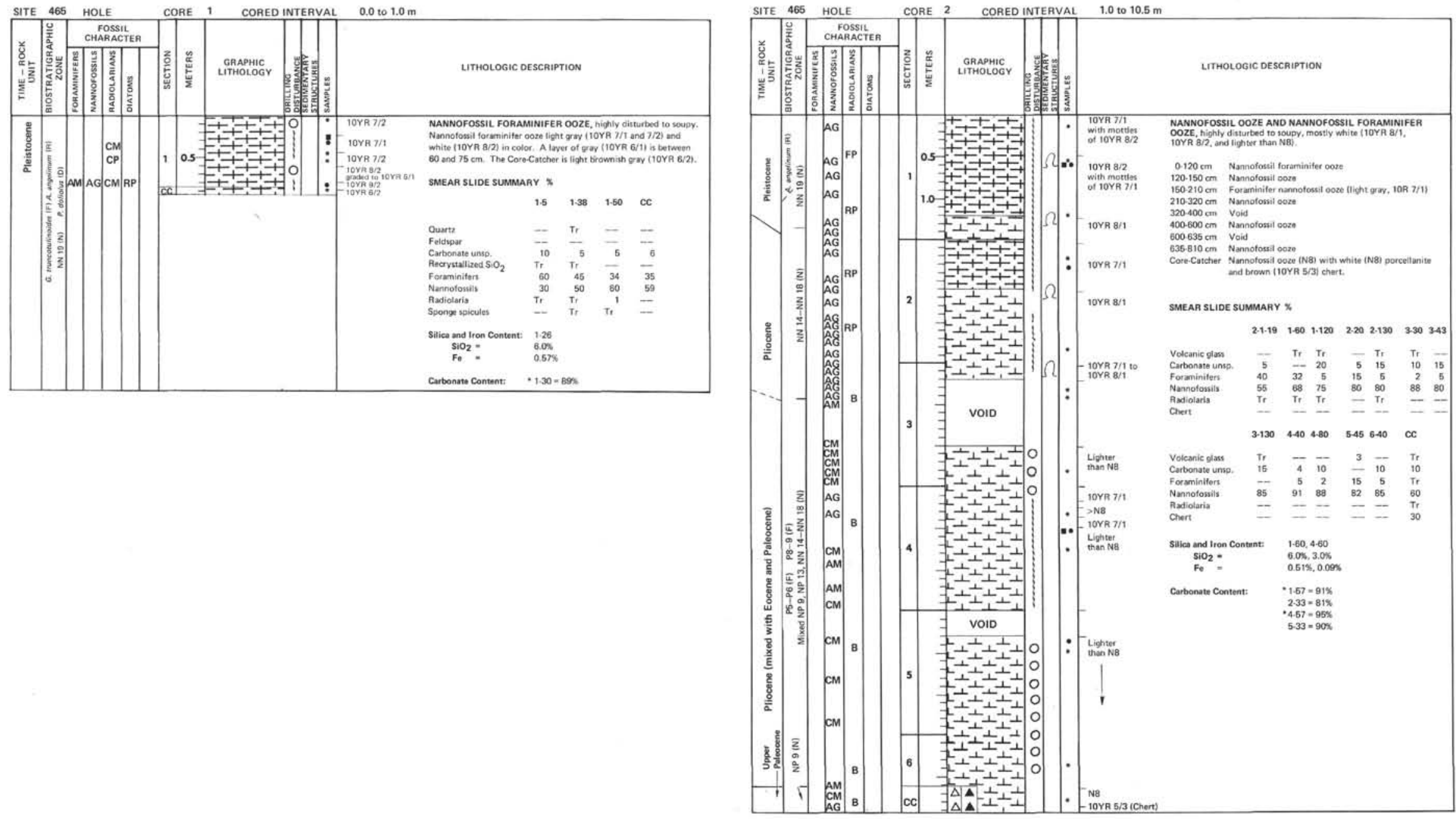

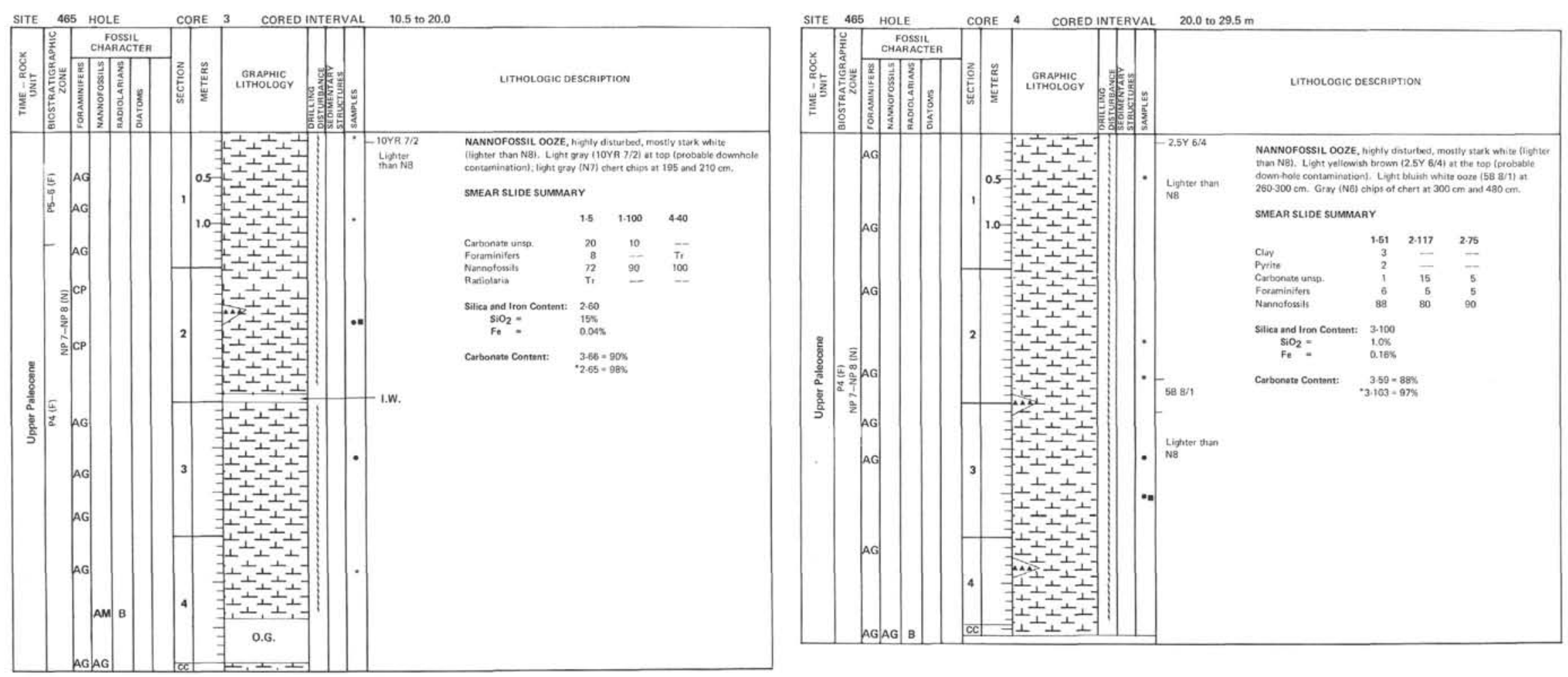

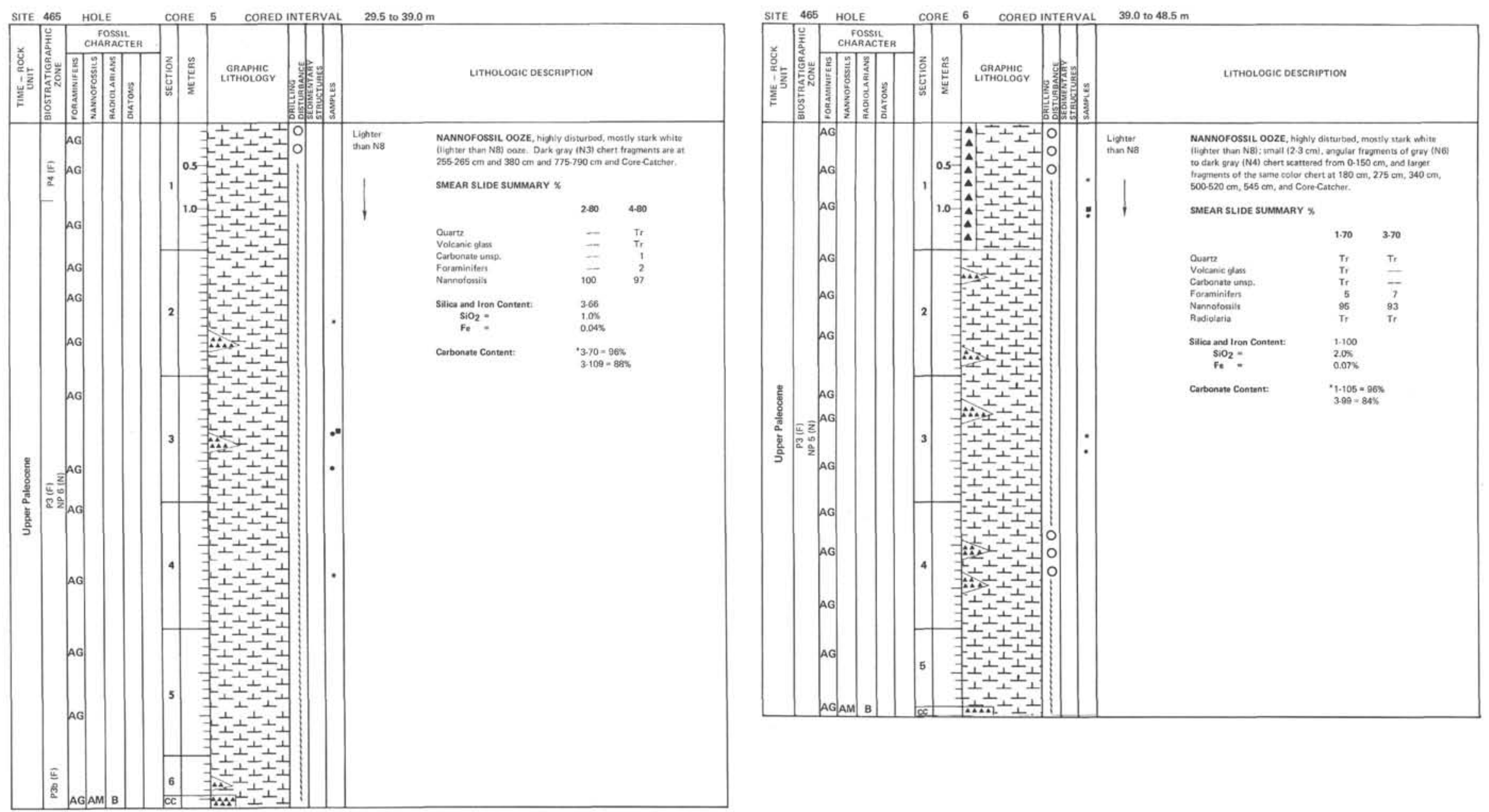

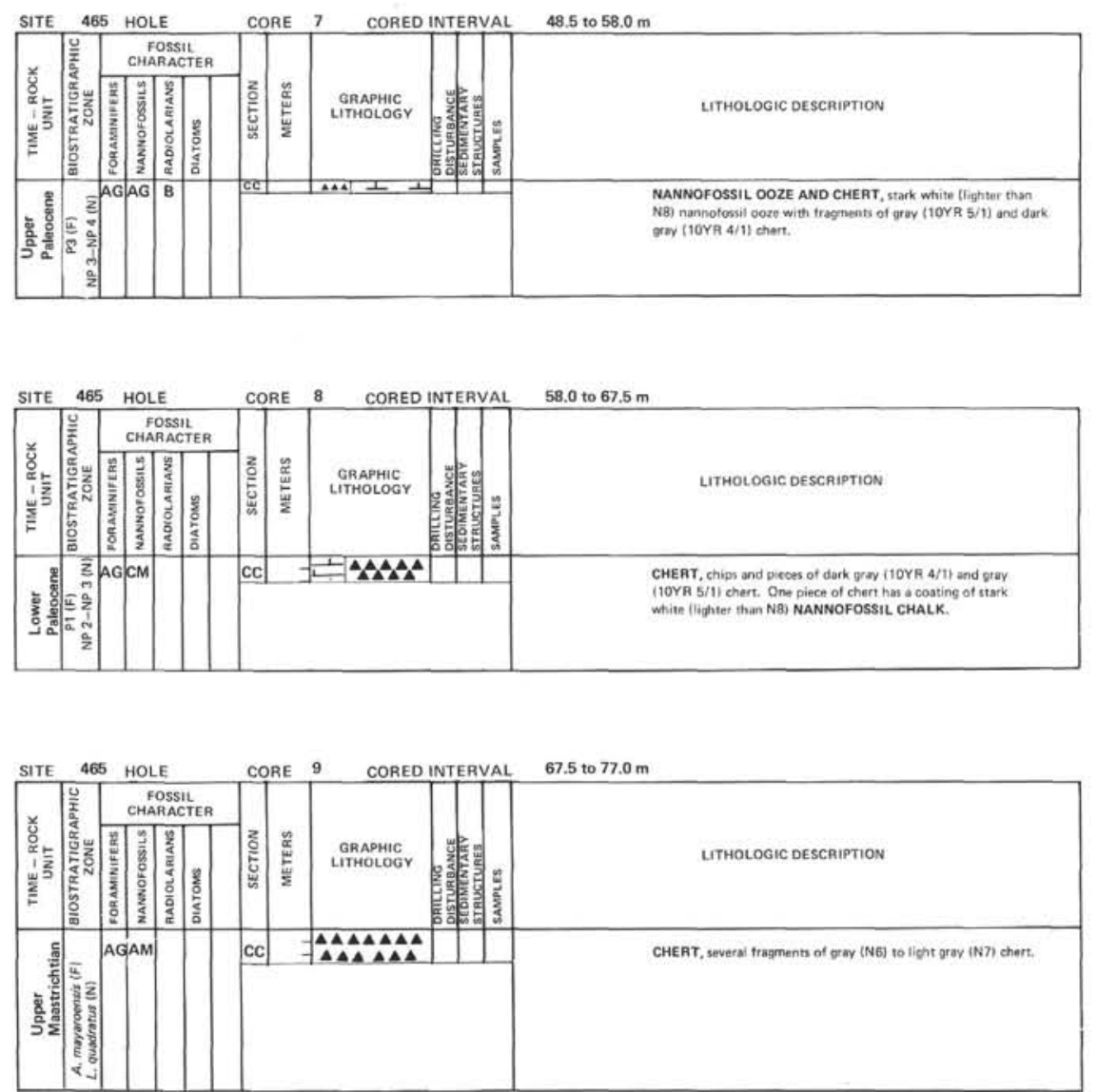

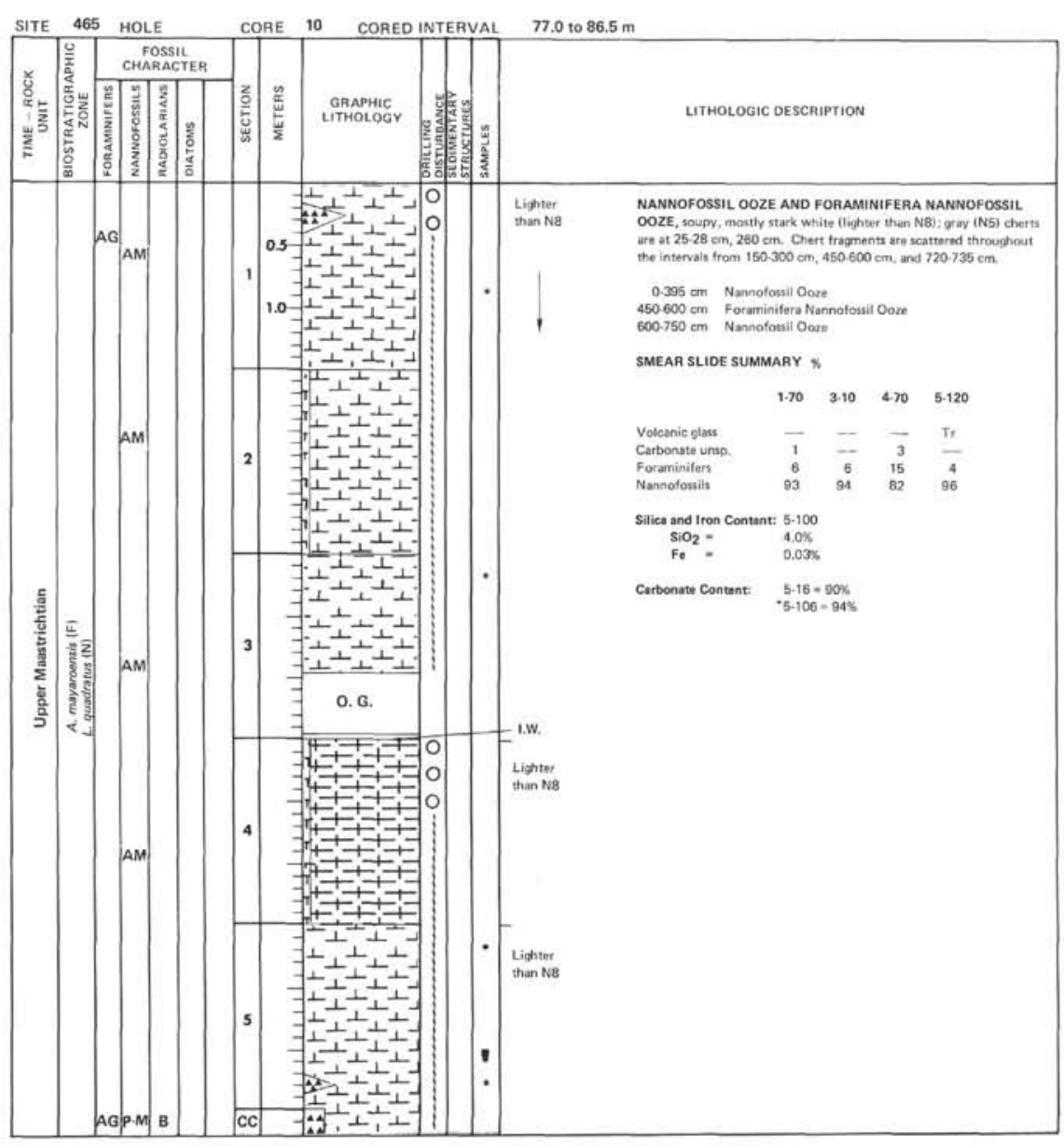




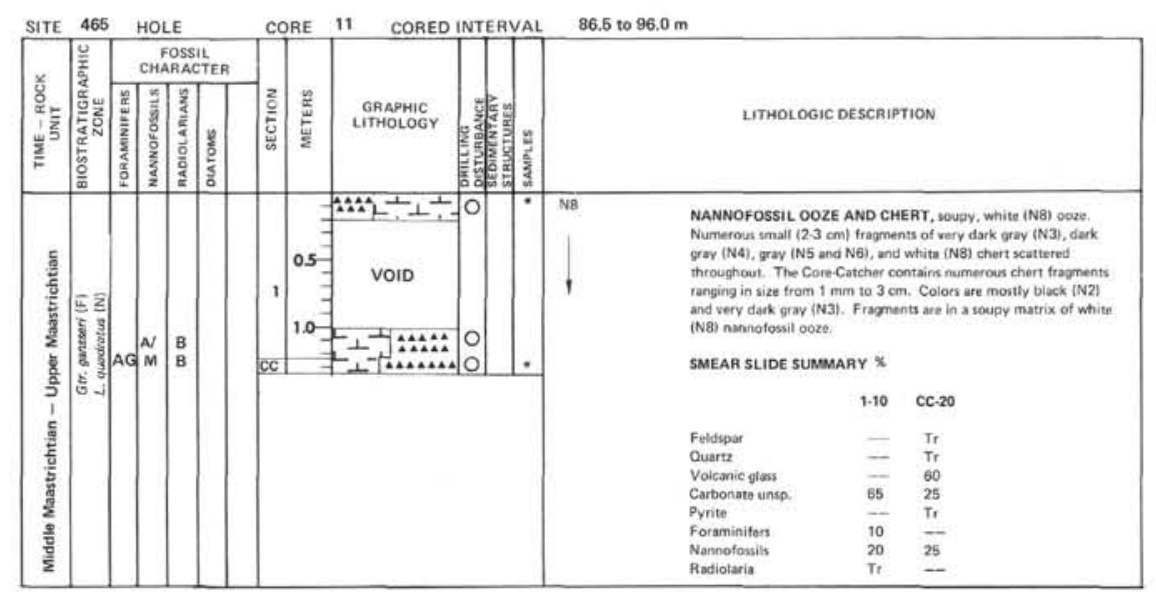



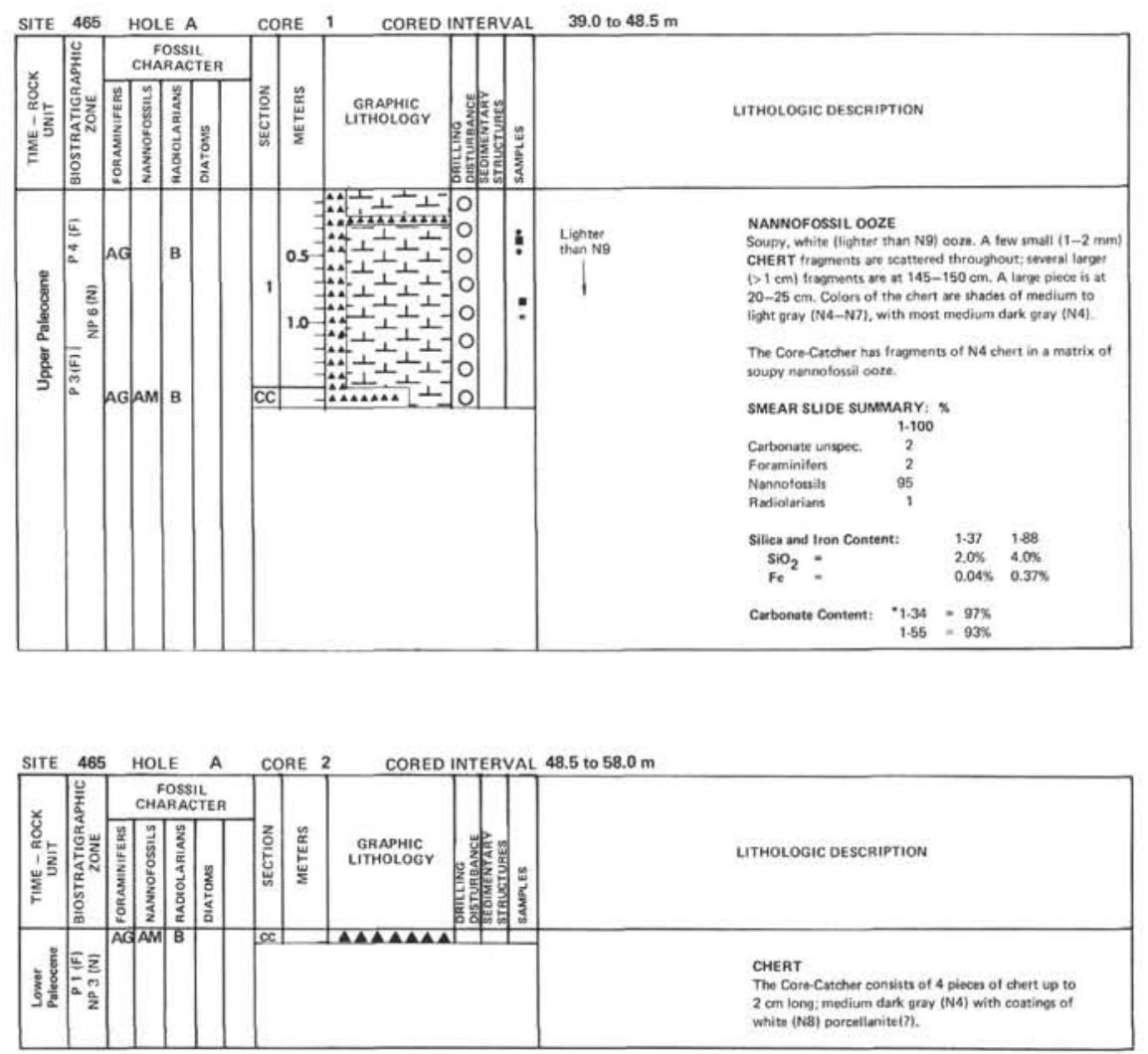

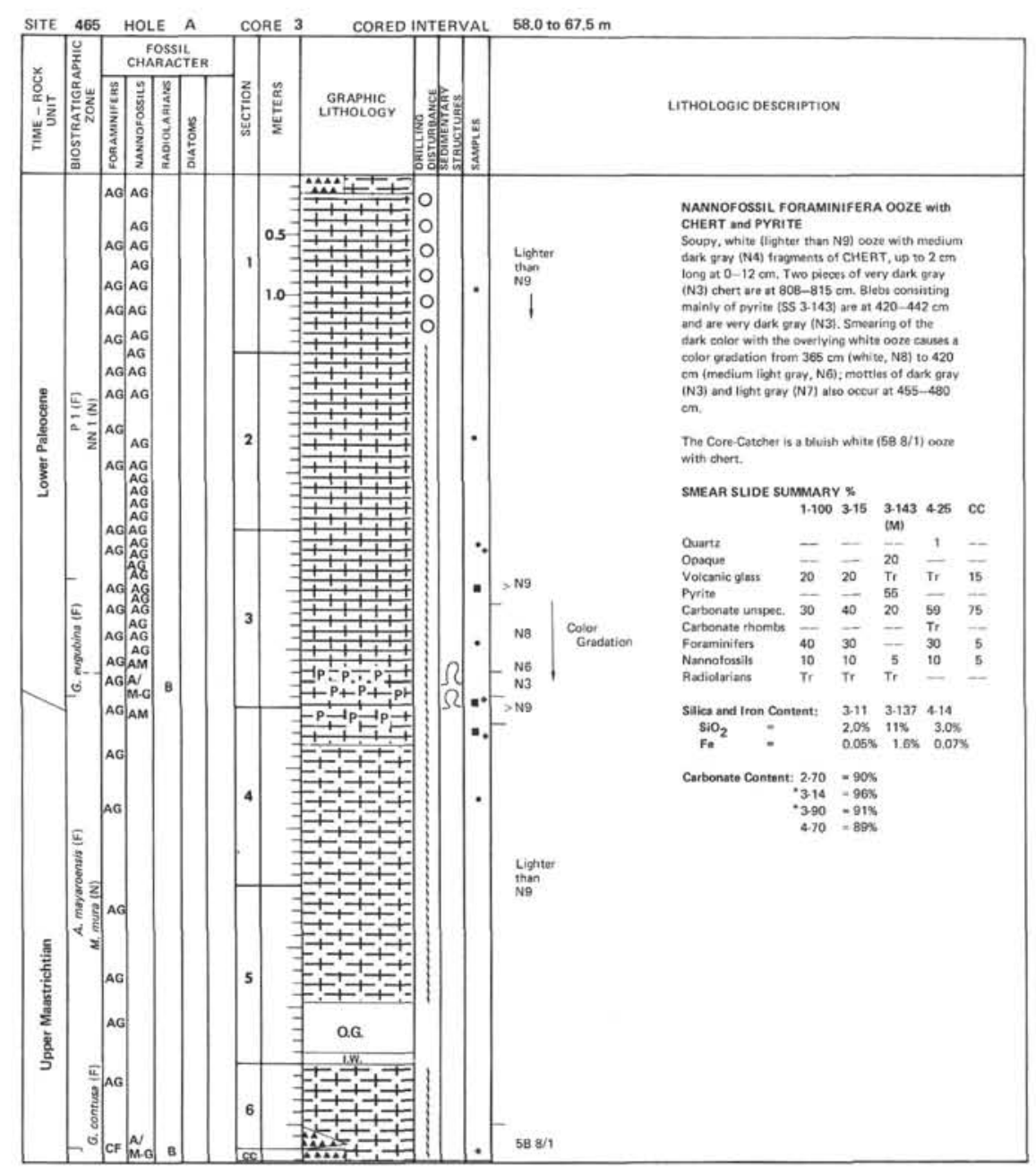



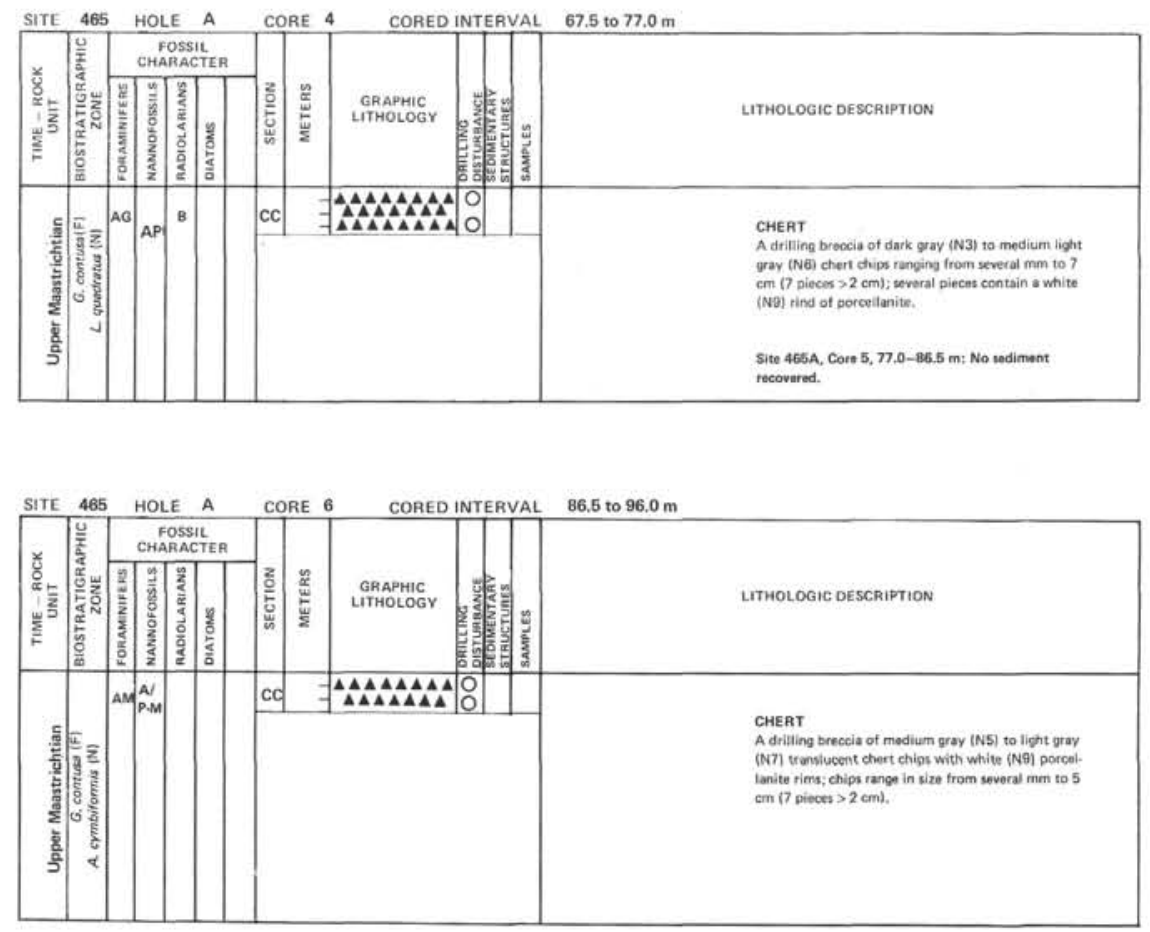

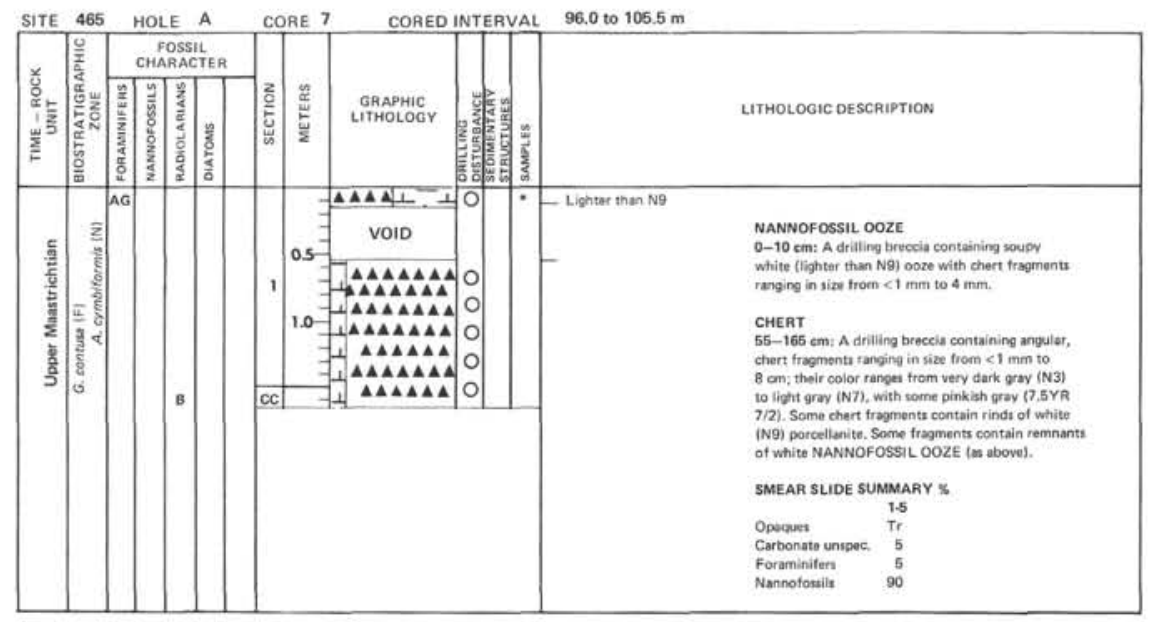

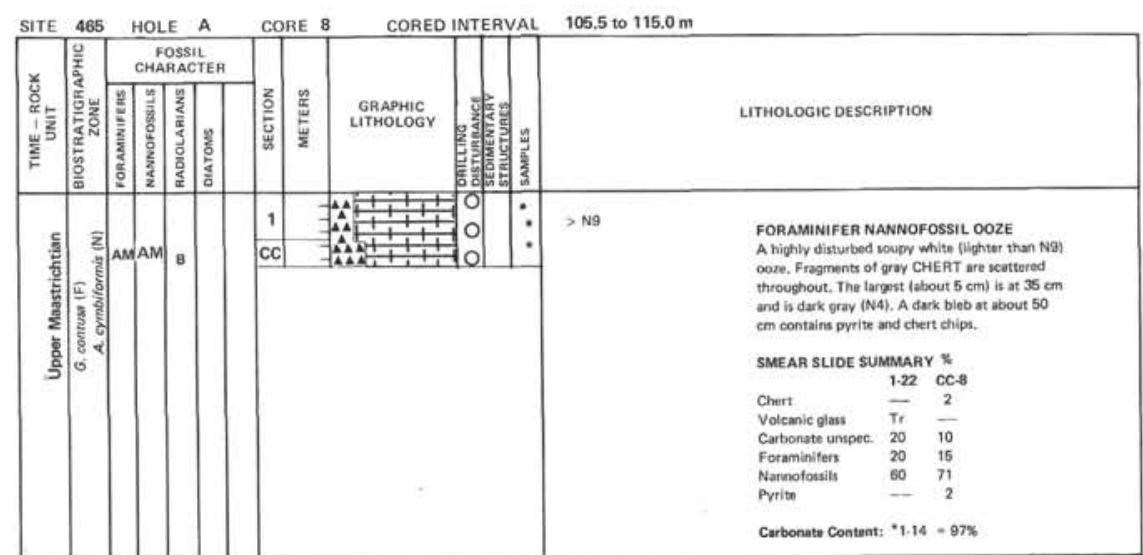



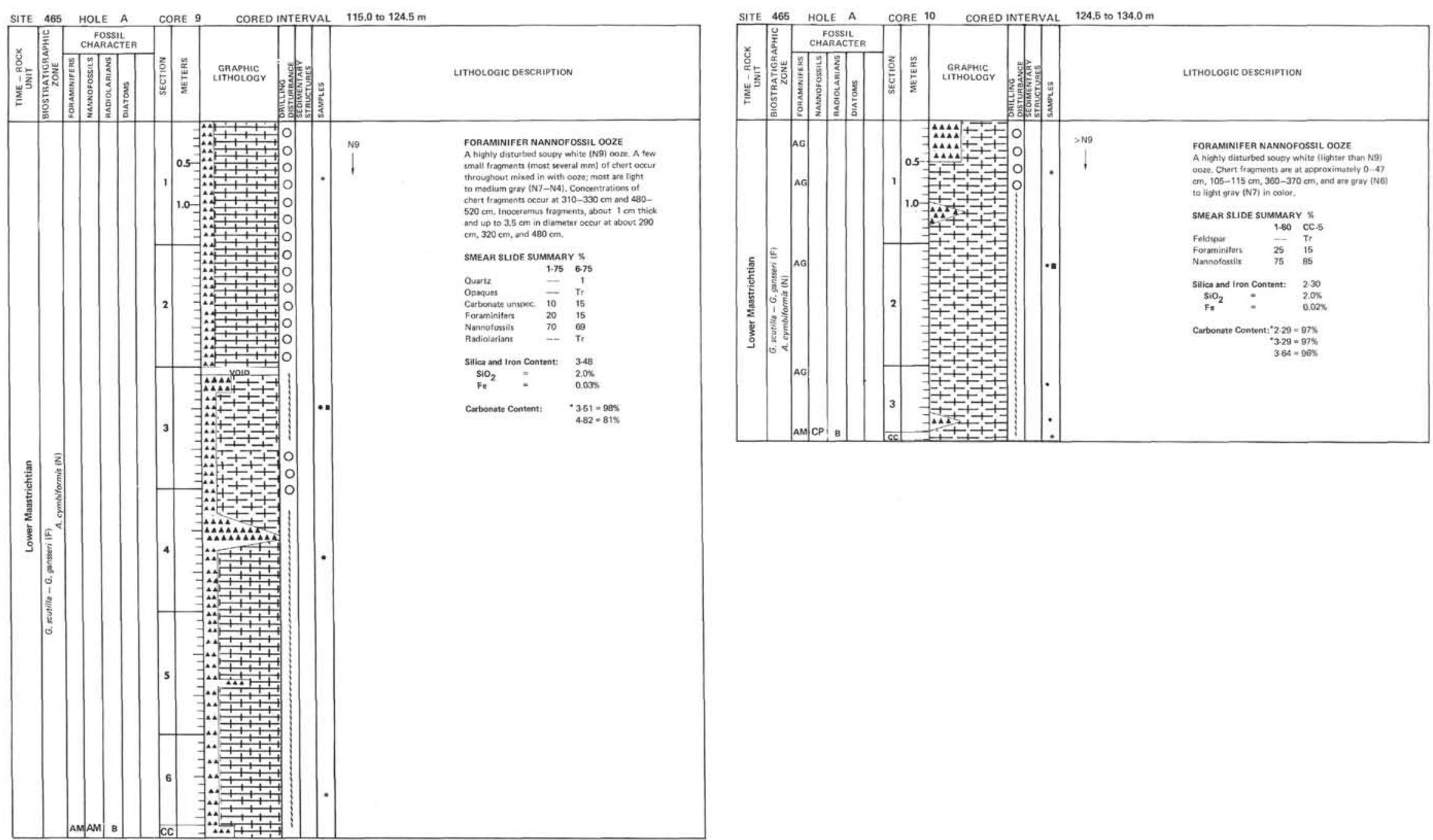

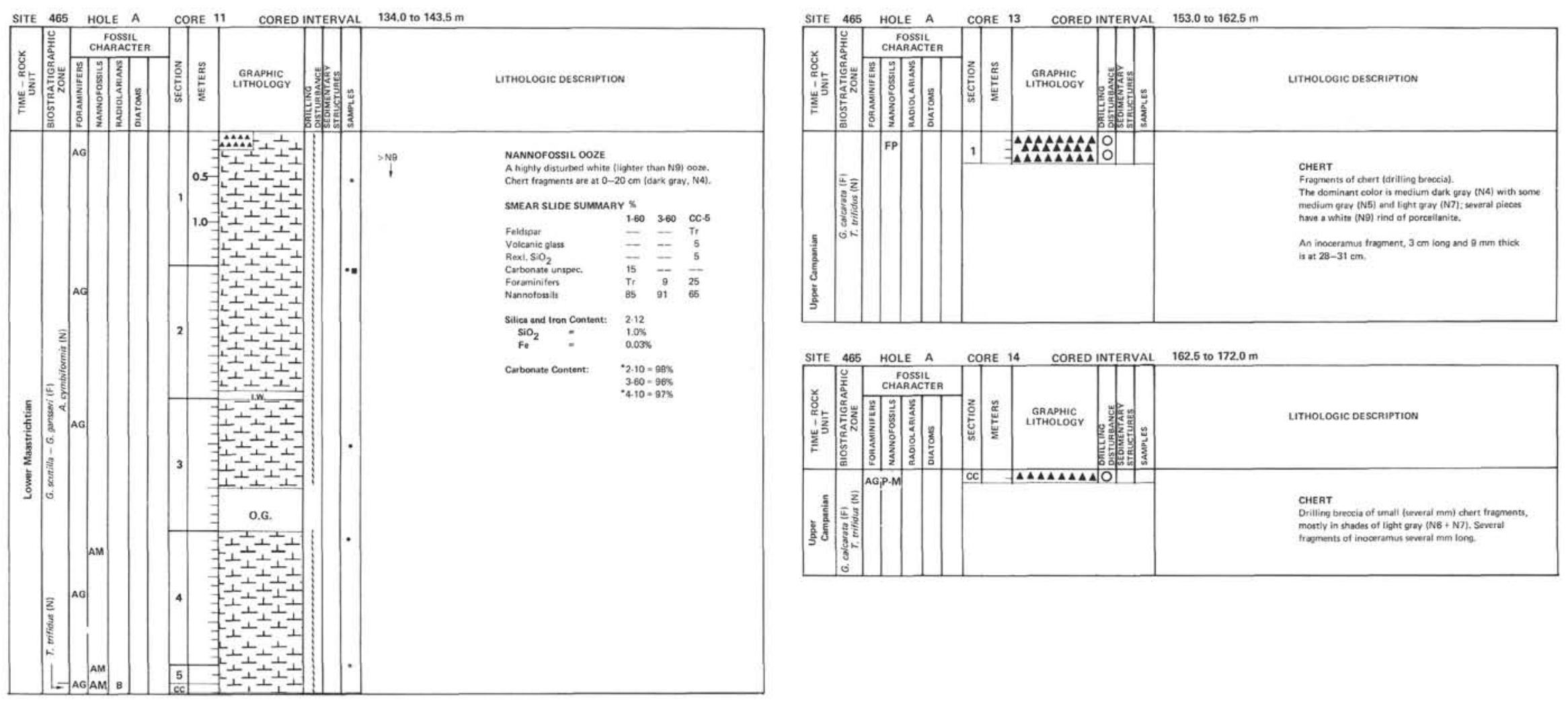

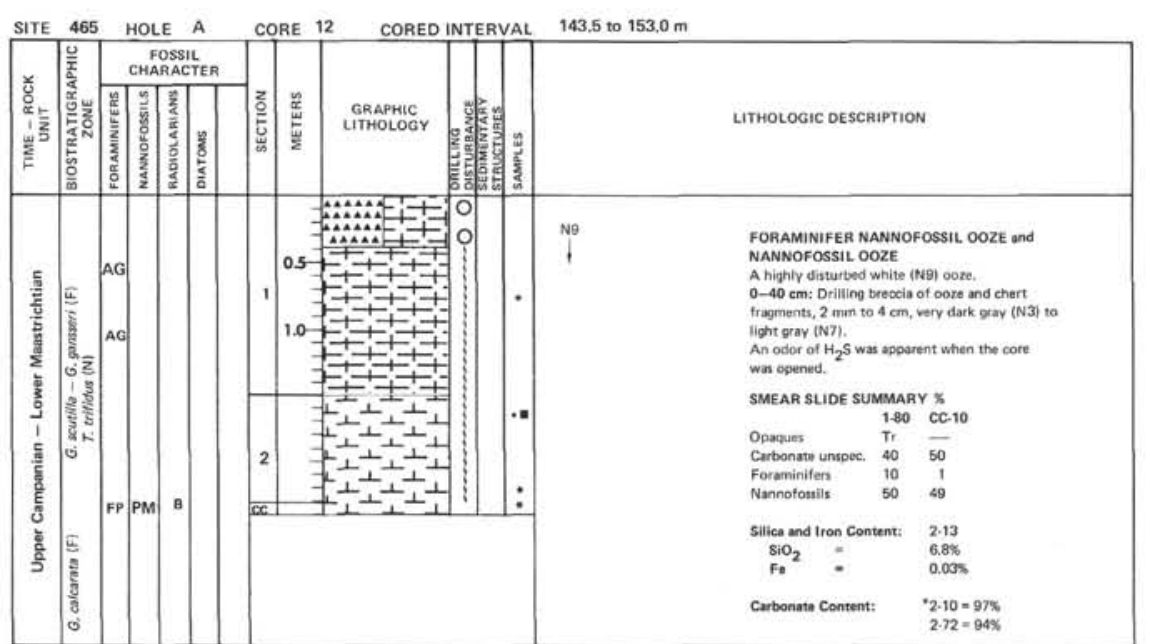



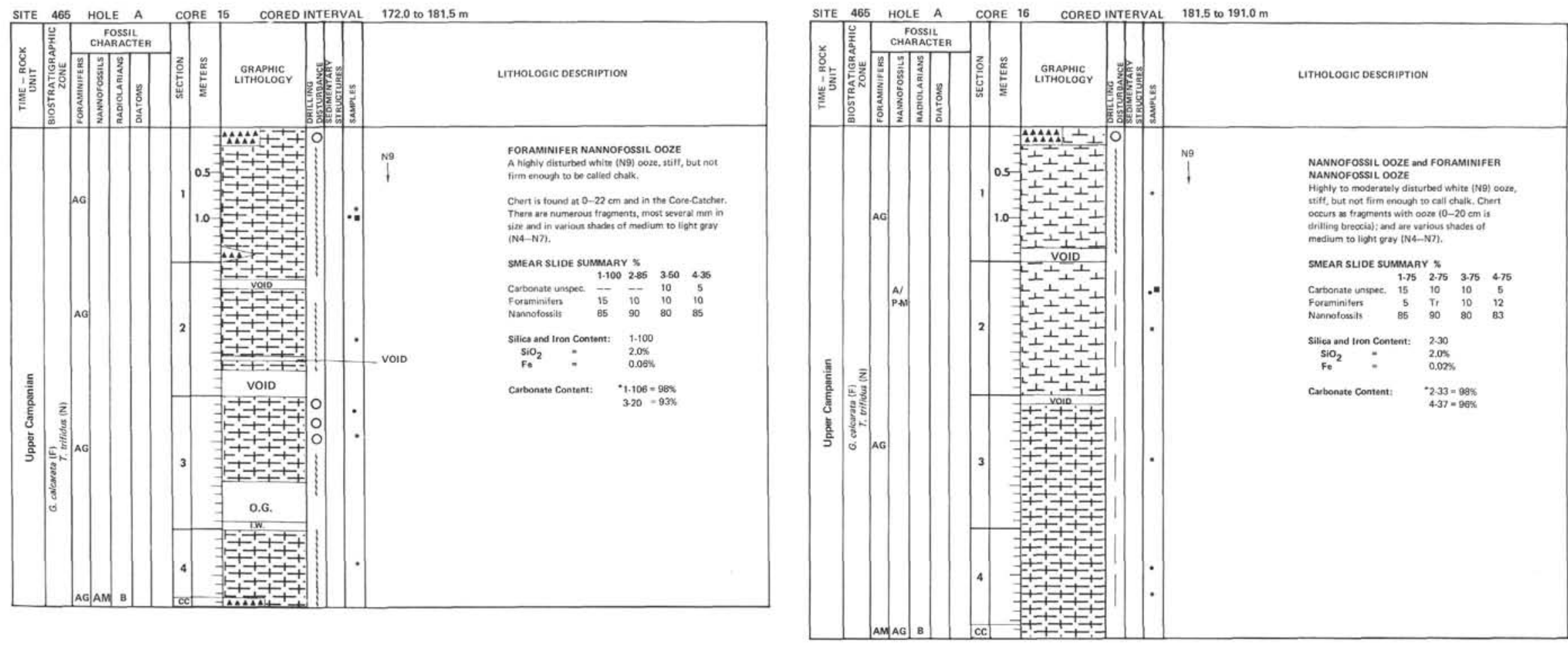

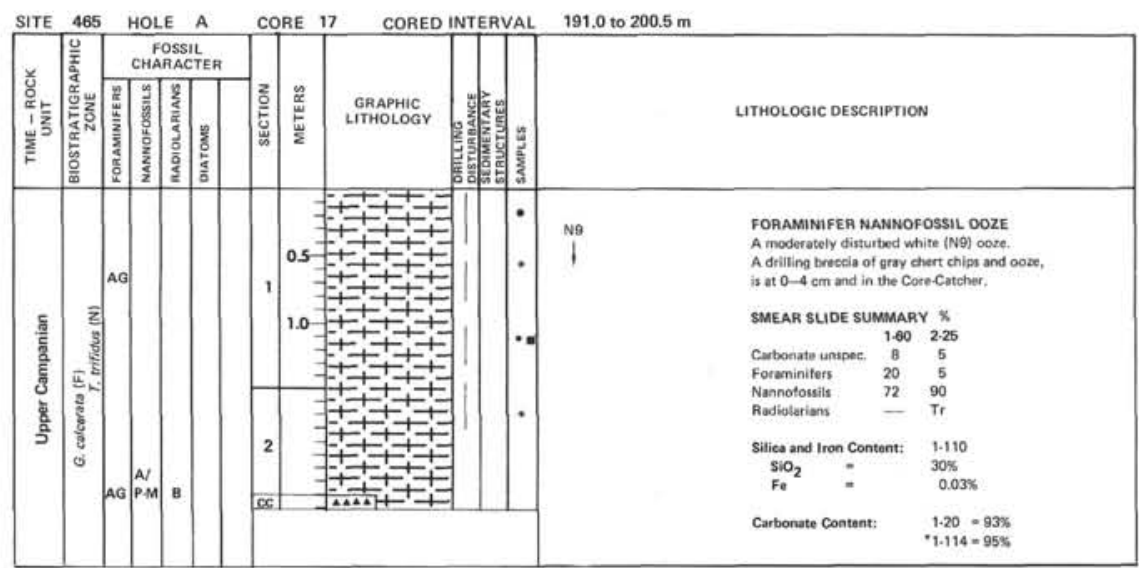



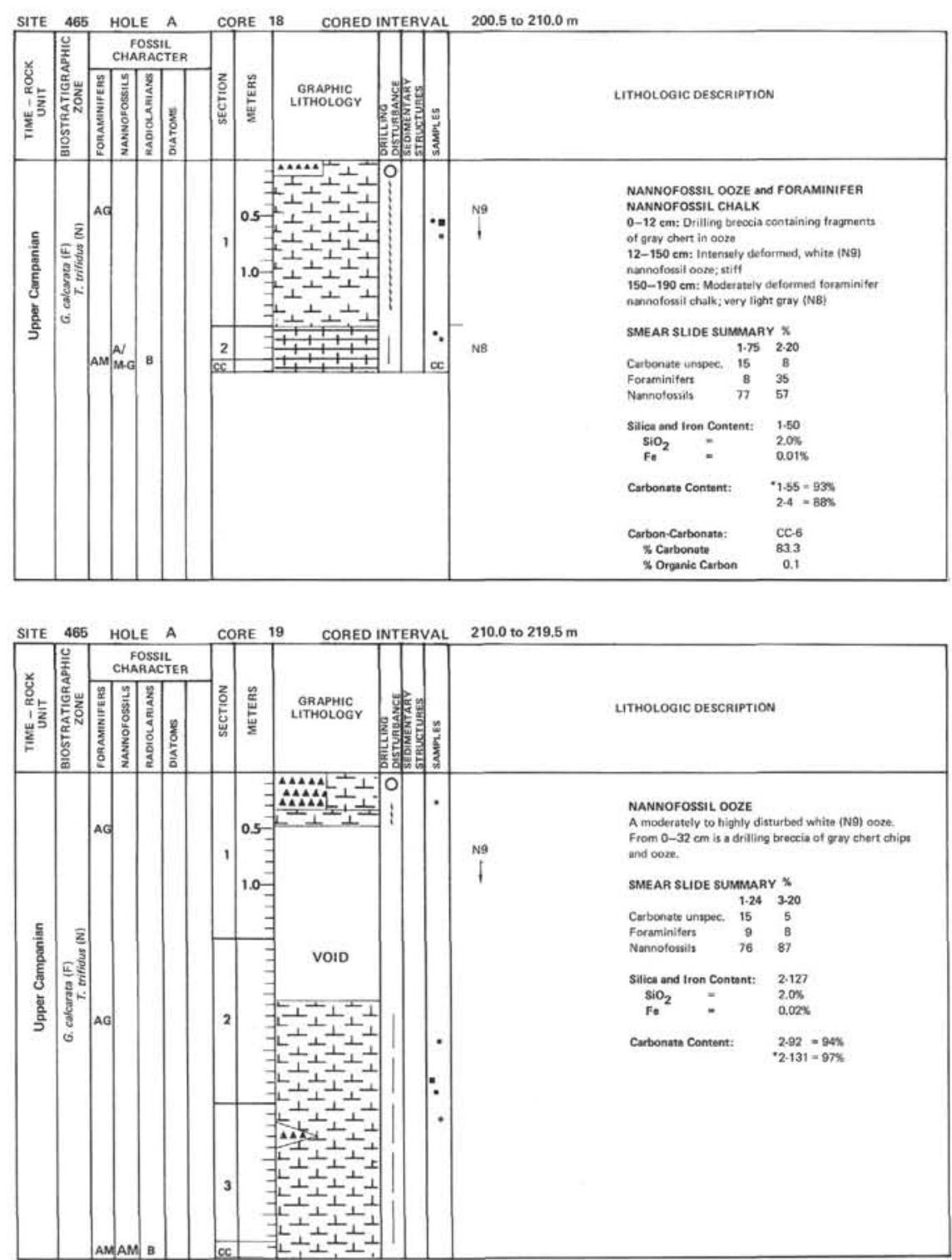

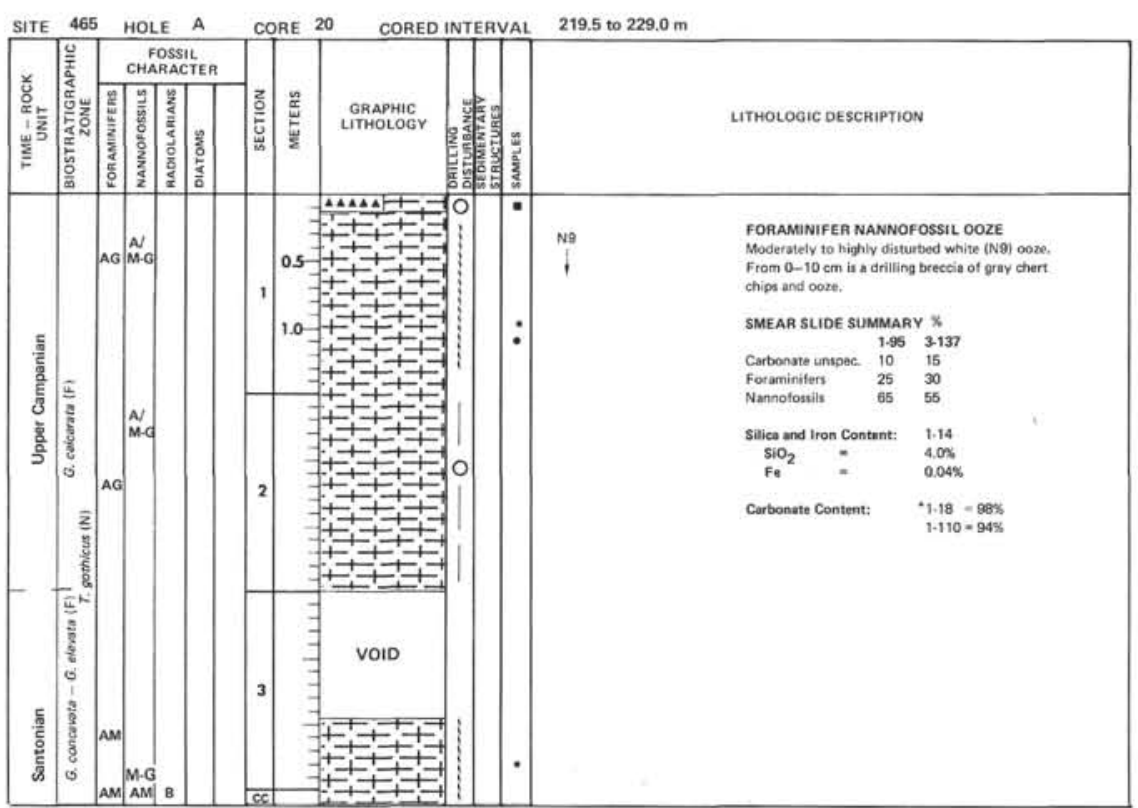



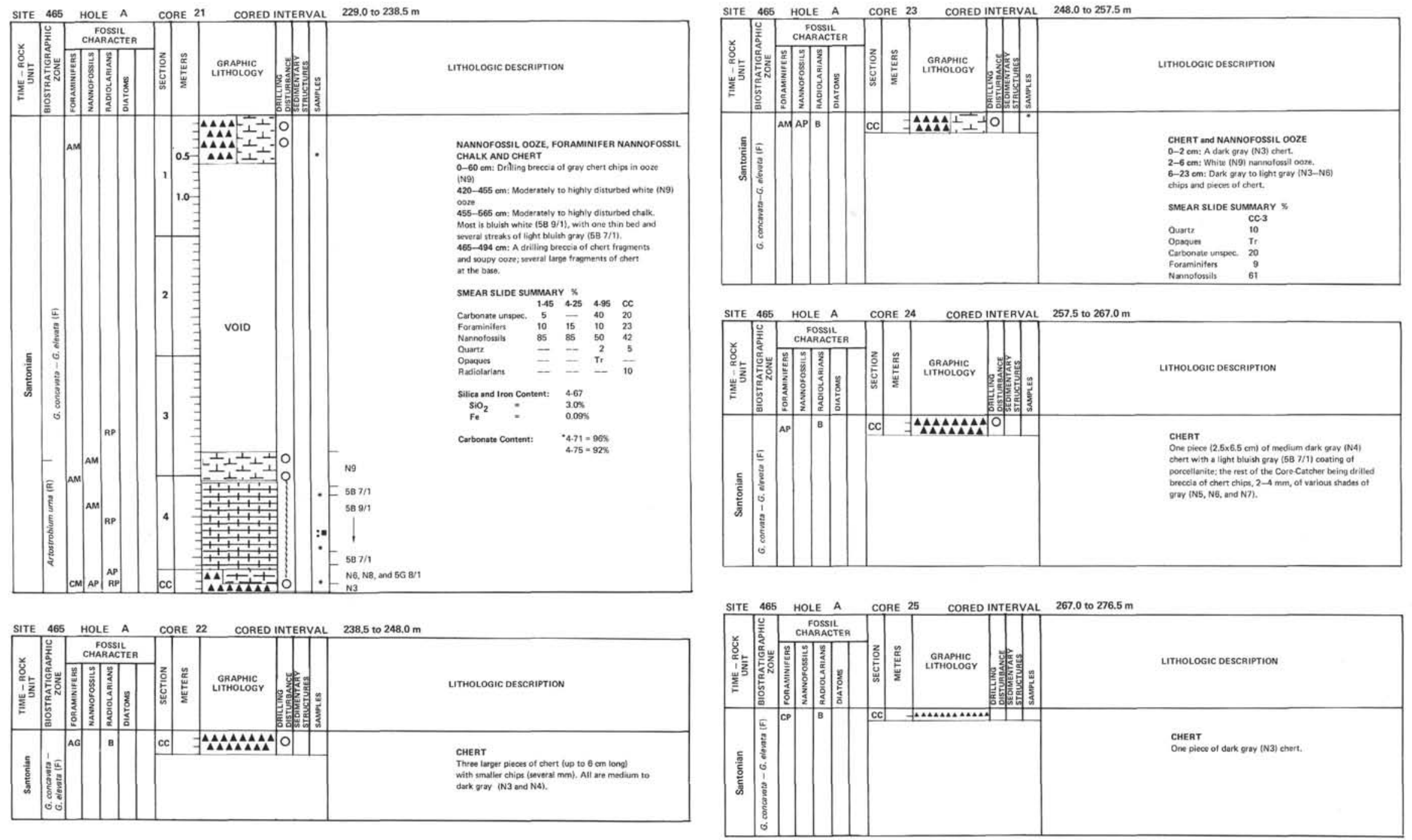

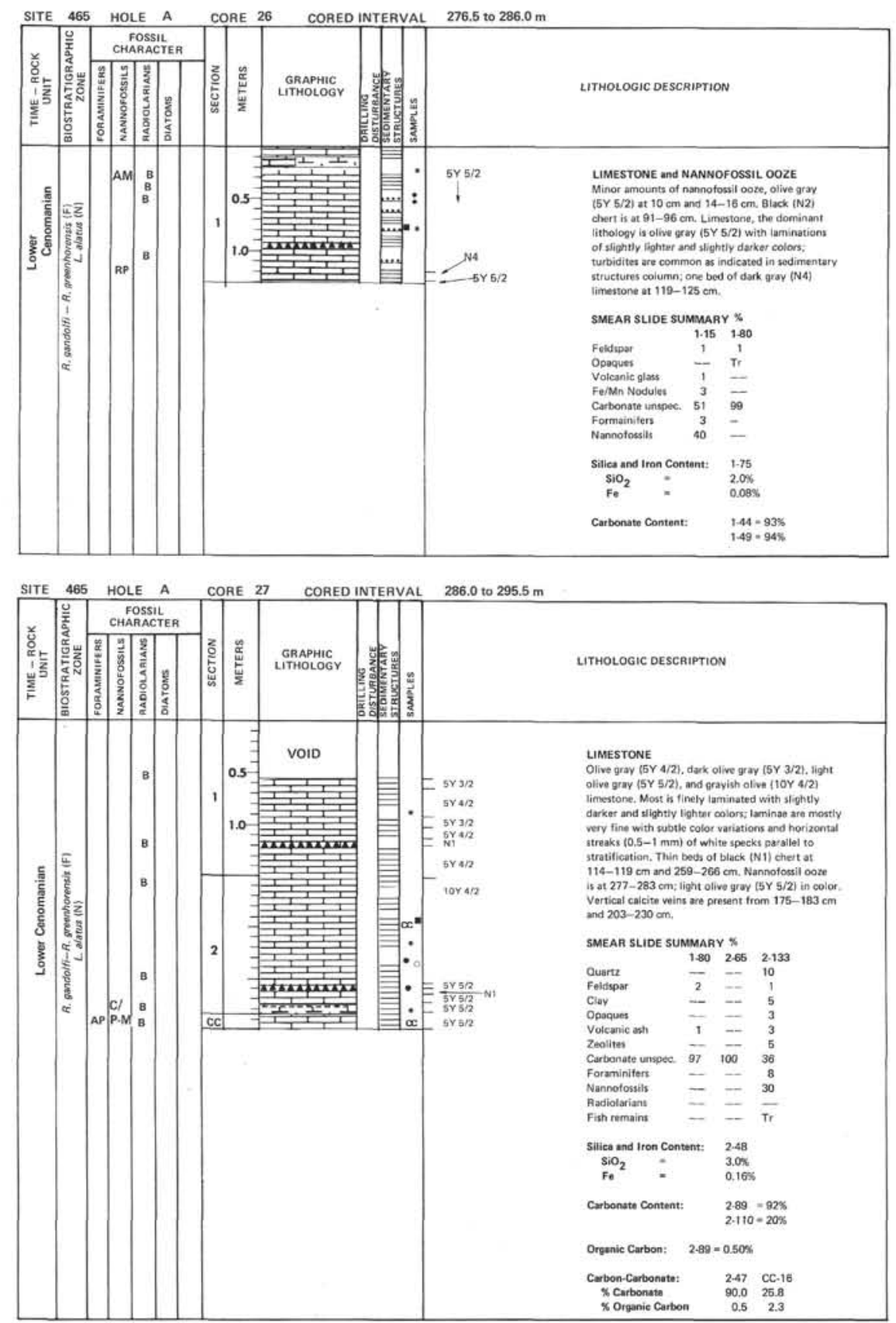

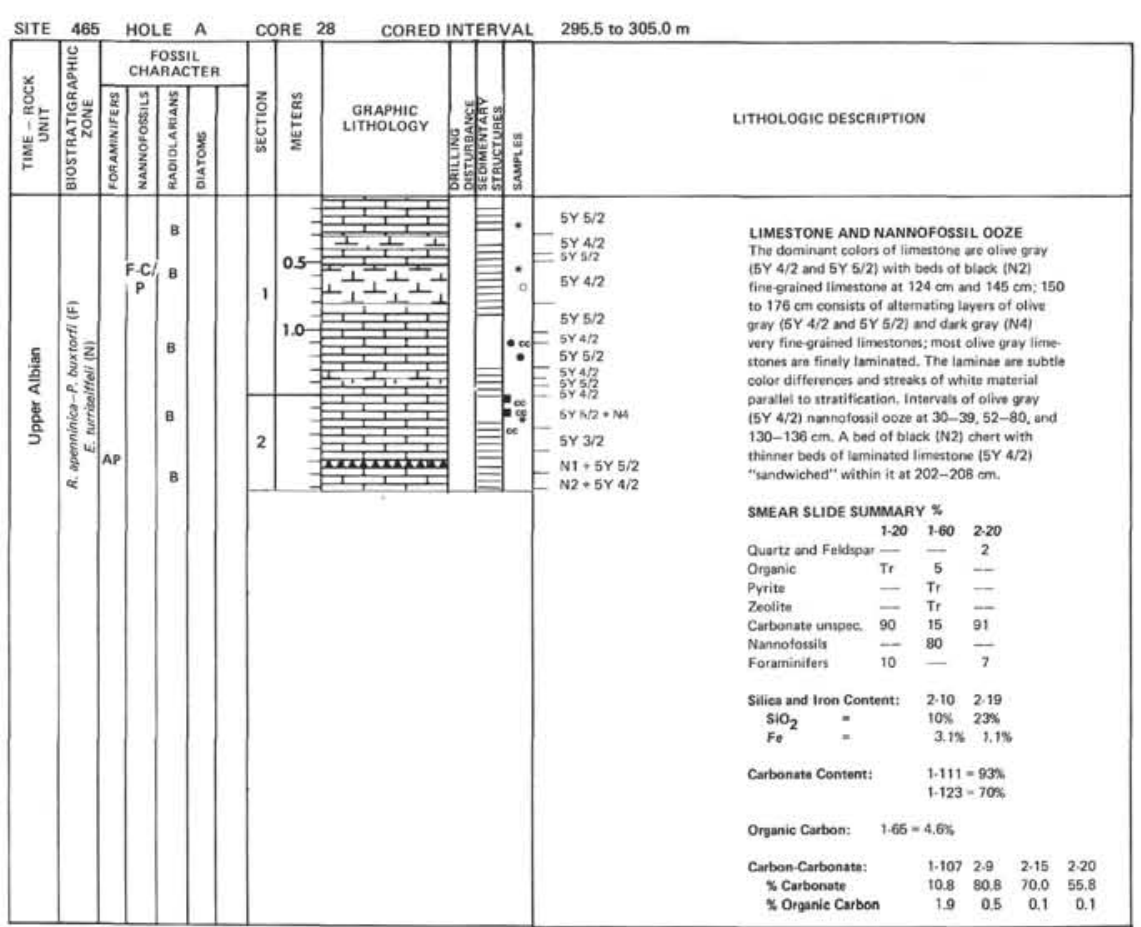



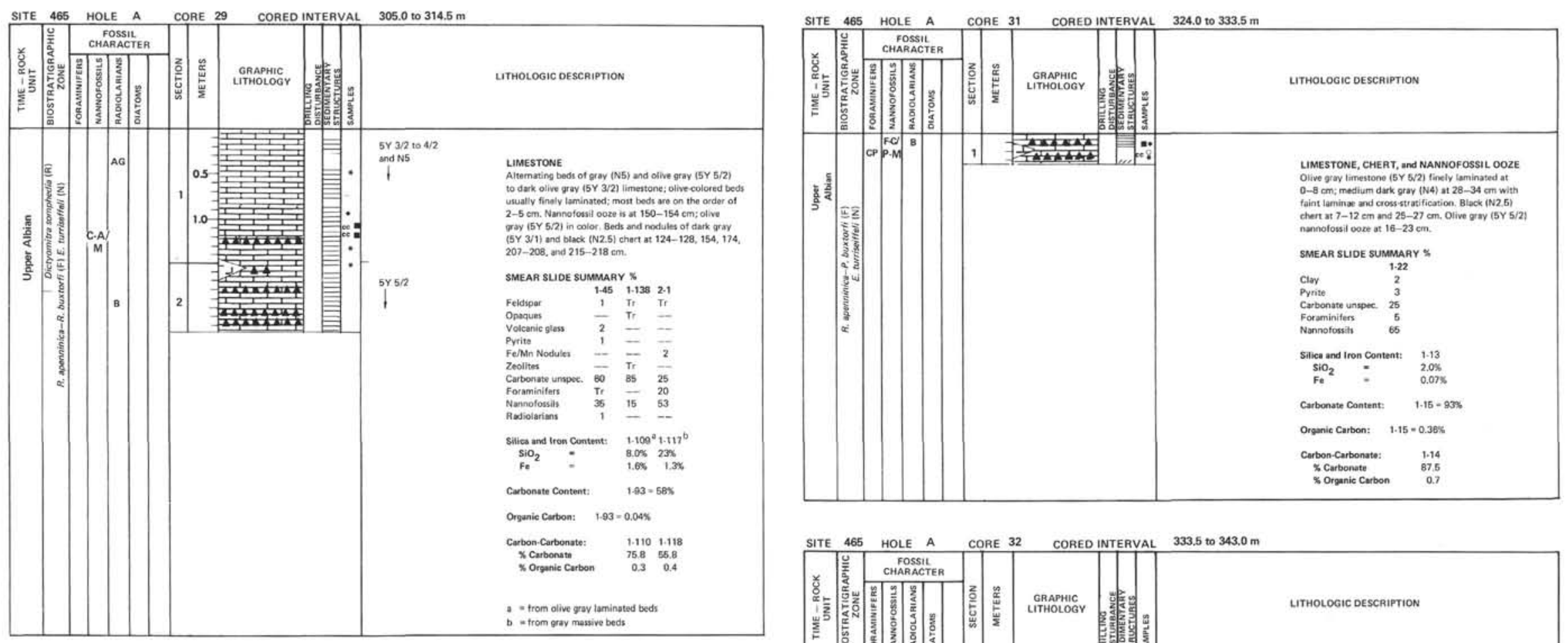

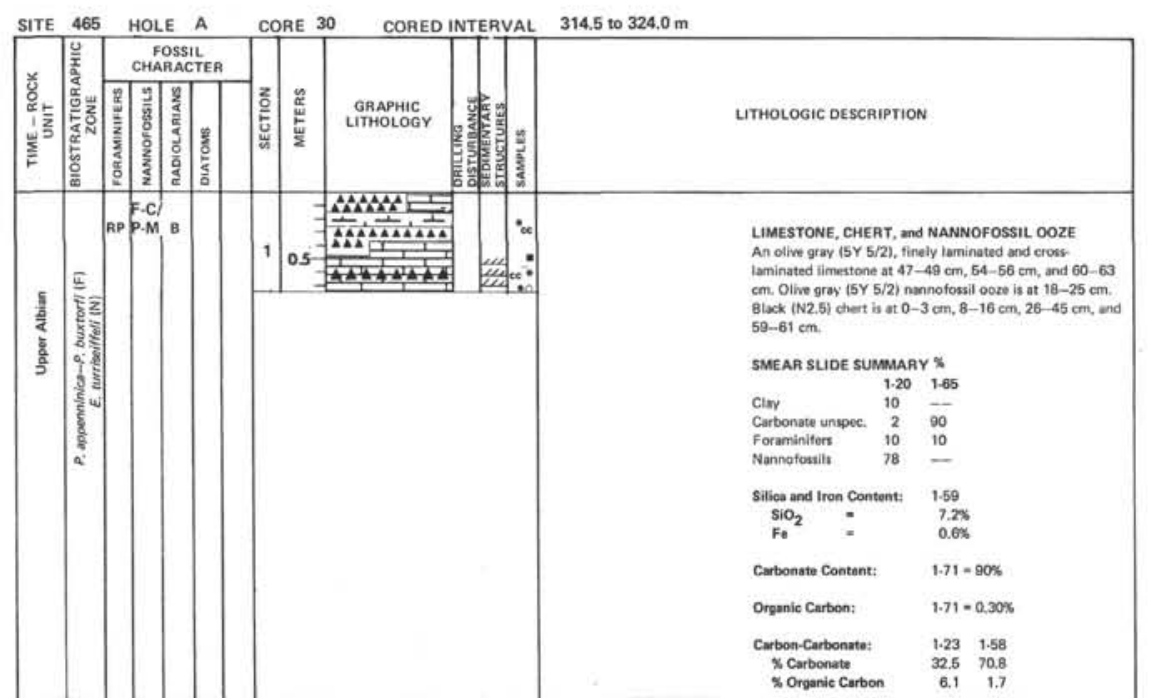

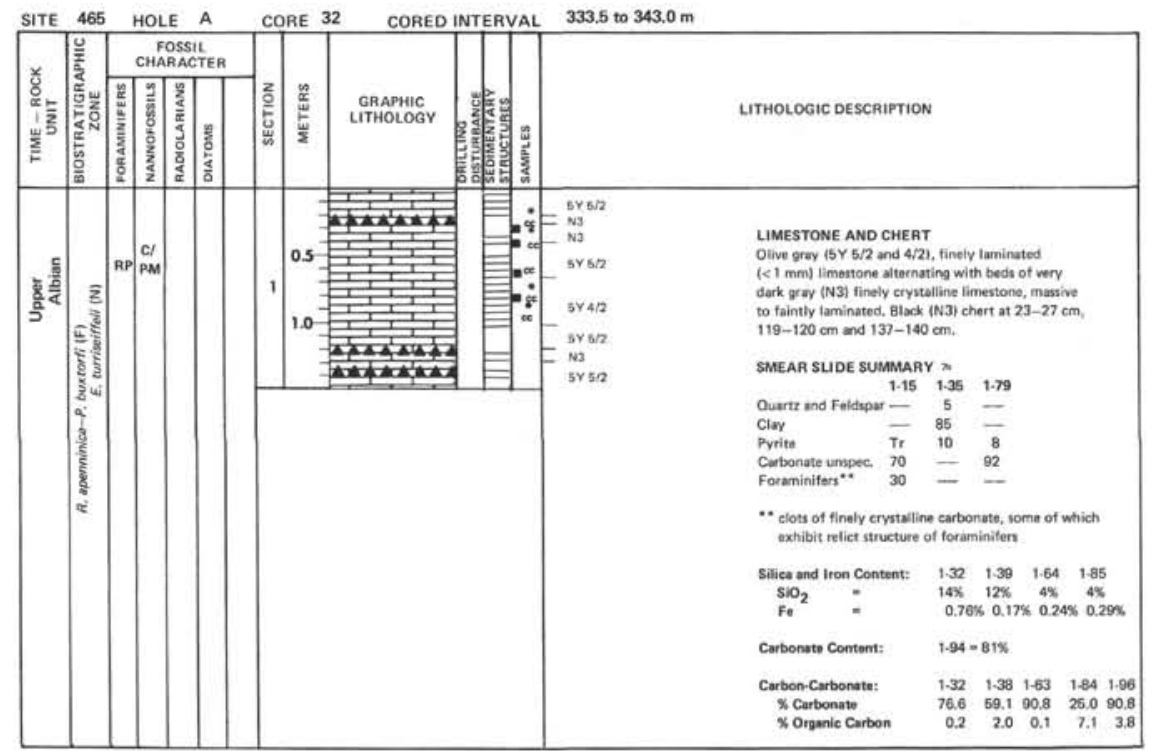



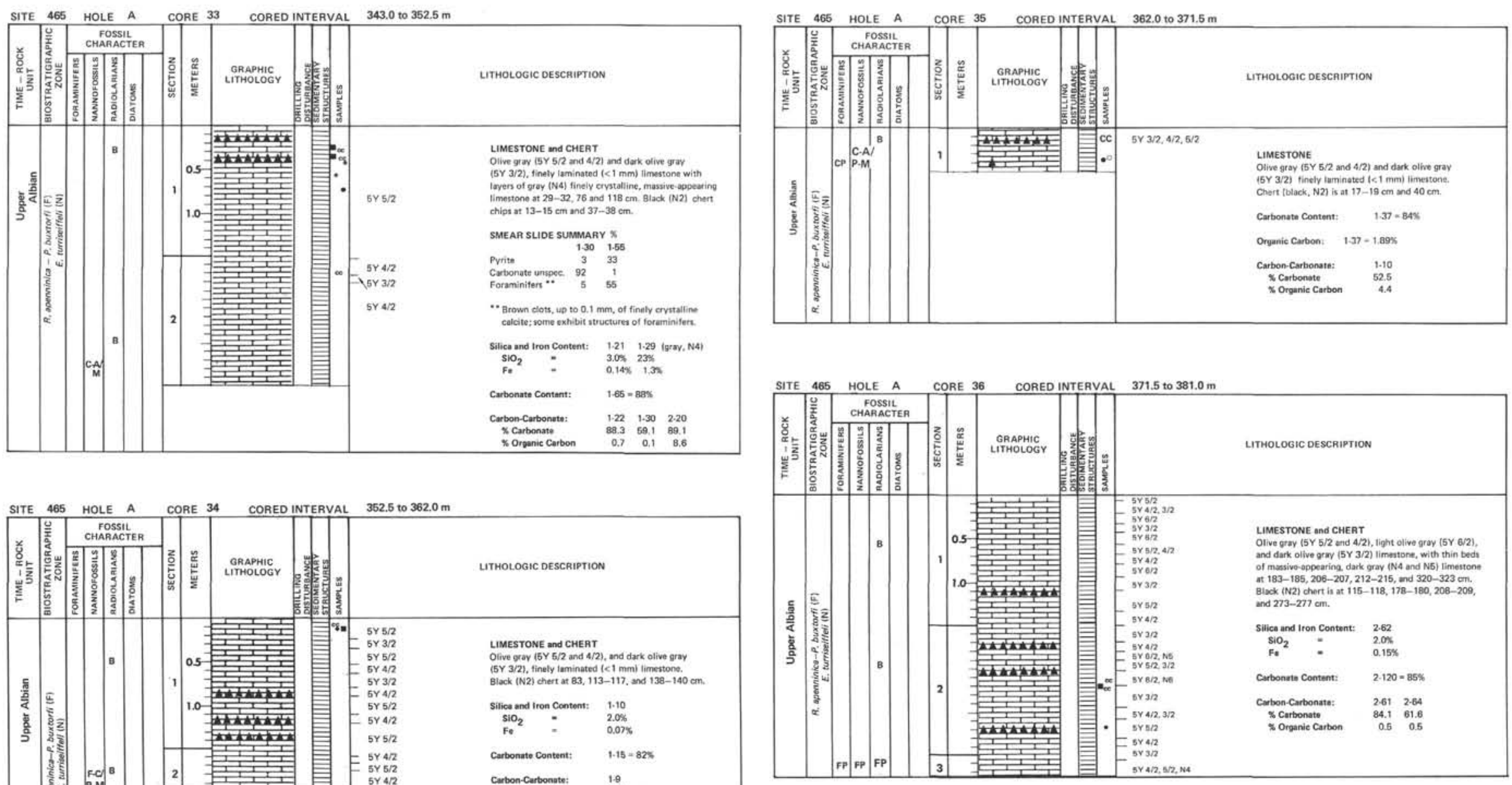

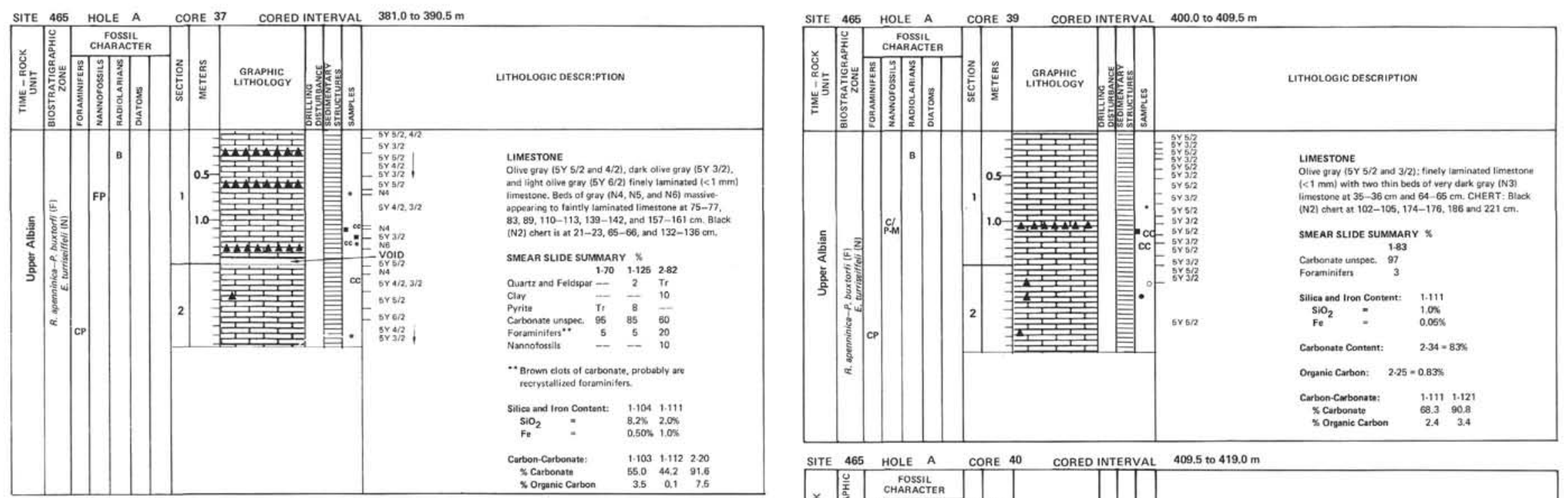

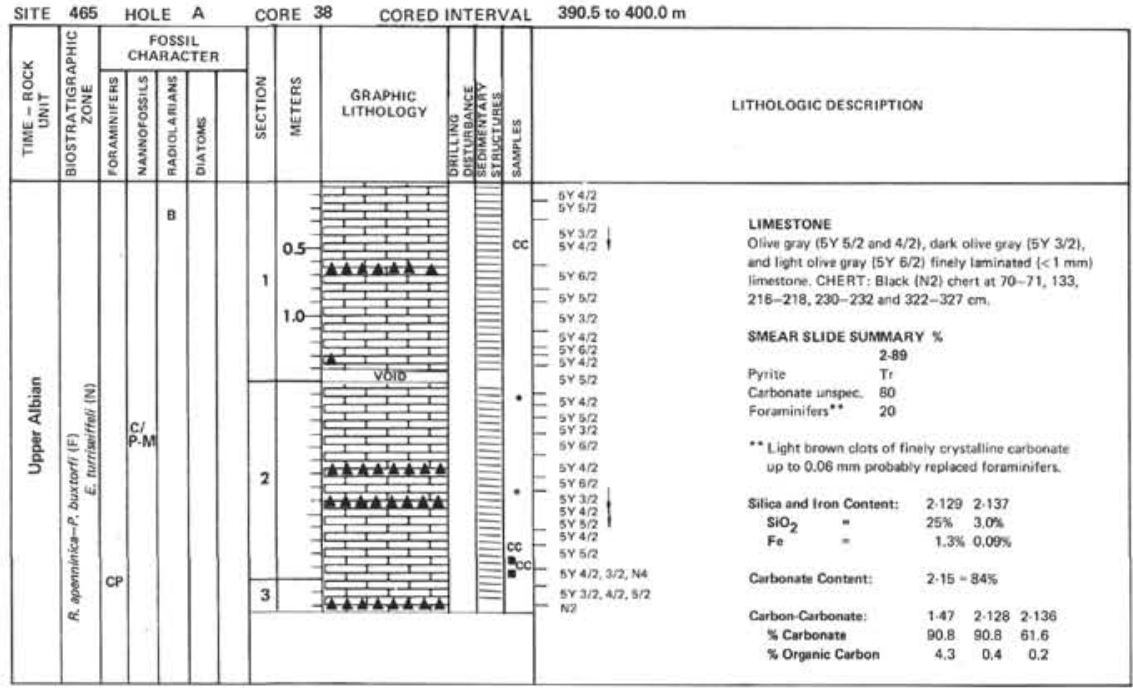

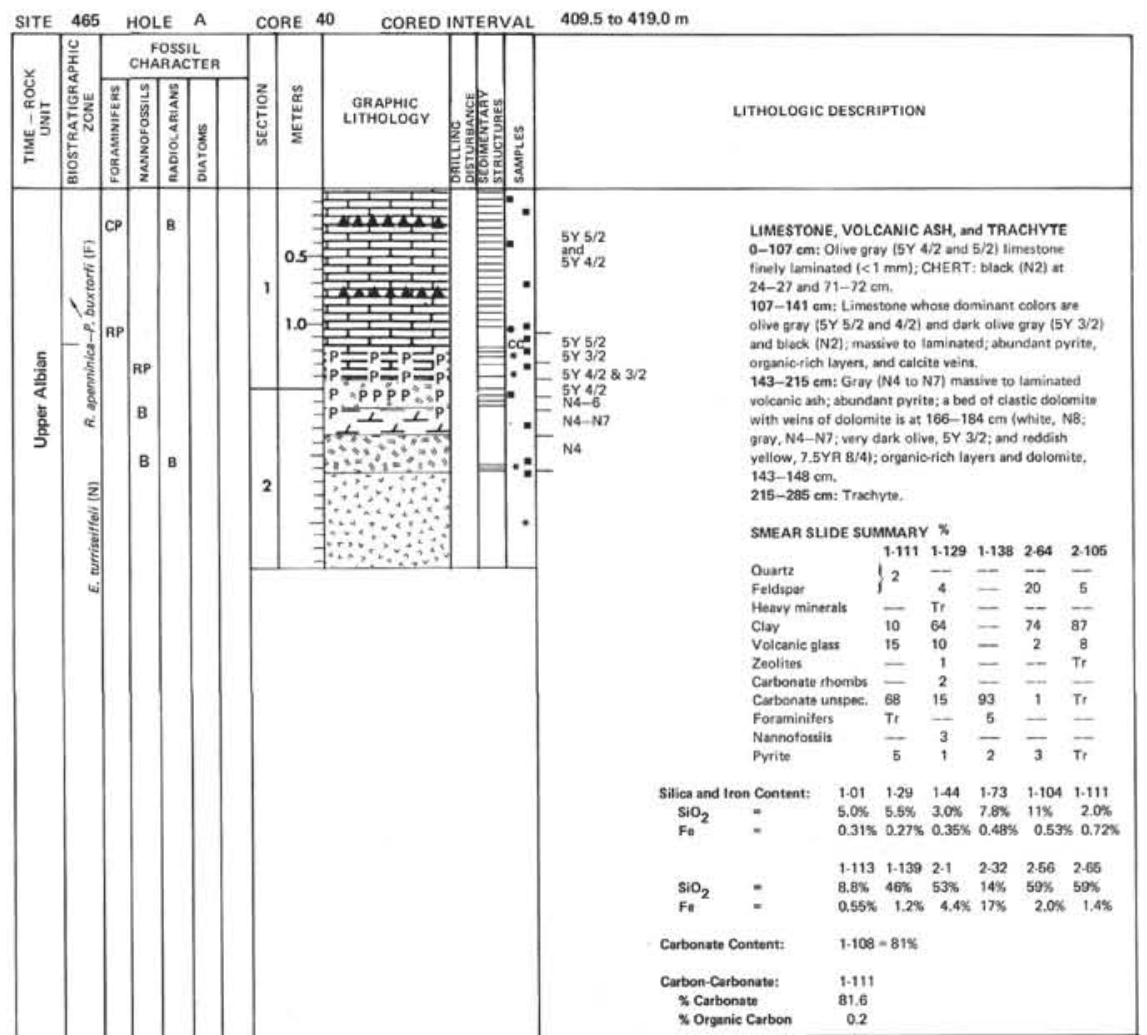




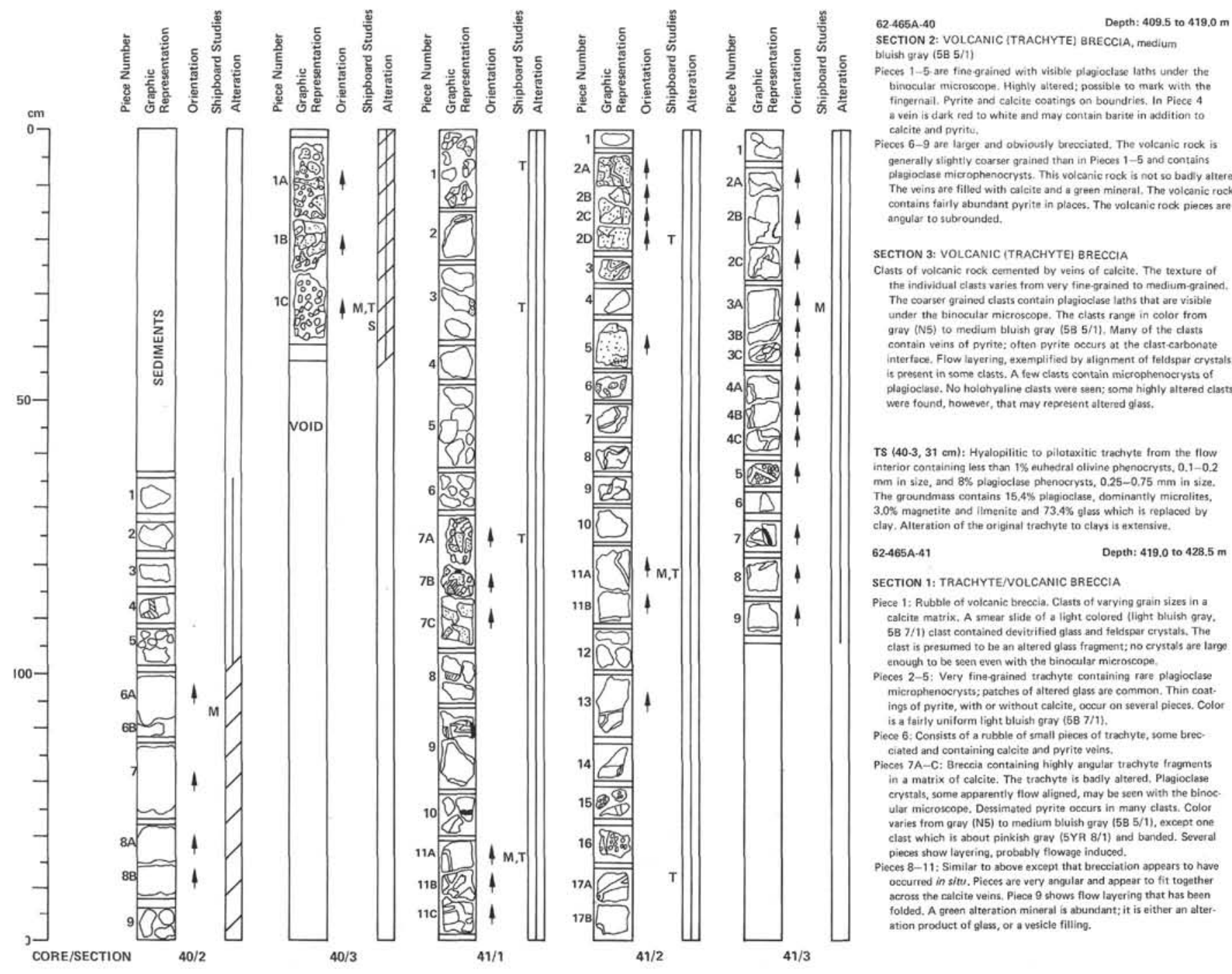

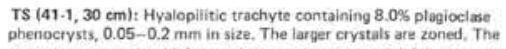
ground mascontains 2.35 plagic

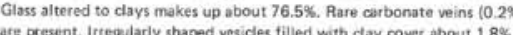
of the surface
TS $(41-1,75 \mathrm{~cm})$ : Hyalopilitic trachyte from a breccia clast containing 6.25 phenocrysts of piagocilase laths $0.1-1.0 \mathrm{~min}$ in size, same of which are zoned. The groundmass contains $26.8 \%$ plagioclase micro. litest, 1.26 magnetito, and $65.7 \%$ glass which has been altered to clay.

SECTION 2: TRACHYT

Altered trochvite gray (N5-N7), that has been highly frocturod: unidentified when in contrast to the upper part of Section 1 . transportation of brecciated classs does not appear to have occurred, a

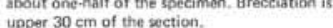
(2)

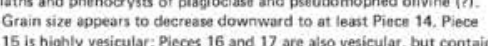
fewer vesicles than Piece 15.

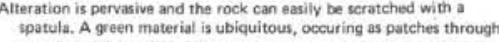

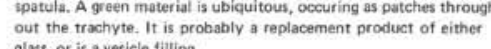
glass, or is a vesicle filling.
Layering is present in Pieces 12 and 13 and possibly in Piece 2 . The invering is pressumed due to tlowage. Layering in Piece 12 is folded TS $(41-2,19 \mathrm{~cm})$ : A trachyte from a flow interior with microphenocrysts
of plagioclase, Magnetite and ilmenite are present in greater that $1 \%$ abur dances, Calcite is present in veins end glass has been altered to clays.

TS (41-2, 82 and $137 \mathrm{~cm}$ ): A hyalopititic trachyte from next to a glassy matrin. It contains both phenocrysts and microphenocrysts
of plagioclase with some partly fresh plagioclase in the groundmass Magnetite and ilmenite are present in greater than 1\% abundances.

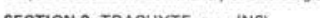
SECTION 3: TRACHYTE, graY INE

Piece 1: Vesiculat trachyte; number of vesicles appears to continu Piece 2. Top of Piece $2 C$ vesiculas. Pieceses 28 and 2 C

Nurnber of open vesicles dactereses from Piece 1 downward and grain size increases to Piece $2 C$.

decroanses to Piece 4C. Piece 5 is fine Piece $2 \mathrm{C}$ through 38 , then size increasess from Piece 5 downwward to bottom of core. Degree of tracturing is reduced from top of core (see Sections 1 and 2). fractures. Fracturing is most intense in Piece $3 C$. Pyrite is very sparse in this section. A dark green material is abundant
throughout the tractyvte. It appars to be either replacing glass or 


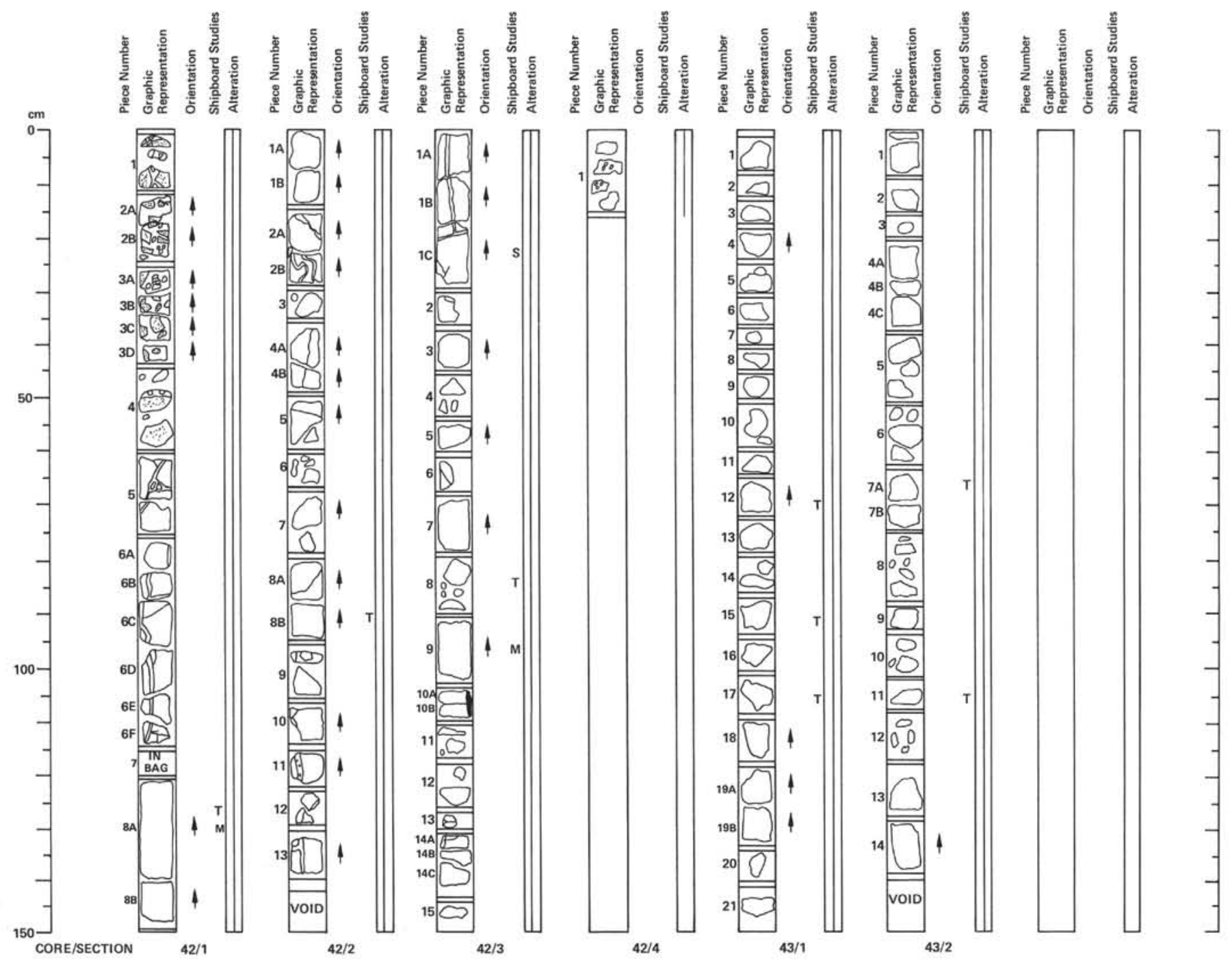


62465A42

Depth 428.5 to $438.0 \mathrm{~m}$

SECTION 1: TRACHYTE/BRECCIA

Preces i-3: Breccia comtaining verv angular tragmentis of troctive tered gats po

toldspars. The matrix is mostly calcite; an unidentified light-green mineral, commonly occurring as crystals, is observed in the open vugs between clastst. Several classts are surrounded by pyrite. ON

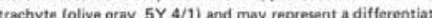
Piece 4 consists of several small, vesicular pieces, One of these exhibits an interfoce of breccia with vesicular tractyve. The

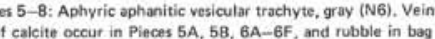
. Is $(42-1,127 \mathrm{~cm})$ : A hyalopilitic vesicular trachyte with $3.8 \%$

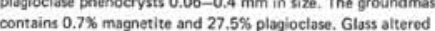
to clay is dominant, $57.4 \%$. Vesicles cover $8.6 \%$ of the surftace and some are tilled Win colcte, 2.4\%

SECTION 2: TRACHYTE, light gray (N)]

Very fine grained aphyric trachyte with many vesicules, Veins are

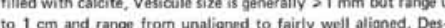

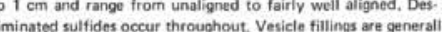
a rim of smectite? and a central filling of calcite.
Pece 5 : Slightly larger plagiocisese microphenocrysts.

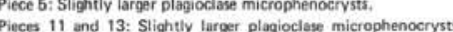
Ts $(42.2,90 \mathrm{~cm})$ : A flow-aligned trachyte from next to a glassy marg groundmass contains plagiociase which in part appears tresh, rate mas.

SECTION 3: VESICULAR TRACHYTE, light gray (N7) Very fine-grained aphyric vesicular trachyte, badiy altered, Moss Veins are filled with calcite.

Vevcules are somet mos oriented, ranging from equidemension sides are dessiminated throustor larger amounts in Pieces $1 \mathrm{~A}$ and $1 \mathrm{~B}$. In Pieces 9-11 the vesilices are filled; ilined with smectite? and Flow unit, Pieces 6-9.
Flow unit, Pieces 9-15.

TS $(42-3,84 \mathrm{~cm})$ : A fliow-aligned trachyte from next to a glassy margin Which contains microphenocrysts of plagioclase, The groundmass con. tains plagiocase which in part appears ir SECTION 4: TRACHYTE, gray (NS)

Altered trachyte, very fine-grained, Two pieces contain a few small
$62-465 \mathrm{~A} \cdot 43$

Depth 438.0 to $447.5 \mathrm{~m}$

SECTION 1: VESICULAR TRACHYTE, light graY (N)

Fine-grained highly altered vesicular trachyte. Small pataltel to
subparallet plagiocise miecropherococrysts throughout. Finely subparallet plagioclase microphenocrysts troughout. Finely
disseminated pyrite in small amounts, concentrations in veins. grained and 1 and 5 tiner grained and mote vesicular.

Flow unit, Picces $6-9$.

Flow unit, Pieces $13-16$

Flow unit, Pieces $16-19$

Fow unit, Pieces 19-21.

政 $1 \mathrm{~mm}$.

IS $143-2,69 \mathrm{~cm})$ : A trachyte which contains microphenocrysts of plagio

lasse. The groundmass contains tlow-aligned plagioclase which is mostiv

resh, raro magnetite and ilmenite, and glasss which has been atter to clay.

TS $(43-1,91 \mathrm{~cm})$ : A hyalopilitic trachyte from next to a glassy

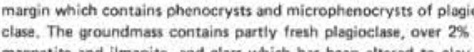
Trapnetite and imenite, and glass which has been altered to clar. TS $(43-1,105 \mathrm{~cm})$ : A hyalopilitic trachyte from next to a glassy

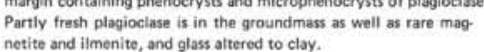
SECTION 2: VESICULAR TRACHYTE, light gray (N7)

Very tine-grained highiv altered vesicular trachyte. Vesicle size row unit pioces lat Pieces 5-7 all very vesicular and fine-grained with only small plagio clase mictophenocrysts.
Flow unit, Pieces 7 70. Flow unit, Pieces $7-10$.
Flow unit Pieces $10-14$

all amounts throughout, Less in Core 43 then in Core 42. Filled vesicles with sment Pieces $1,2,8$, and 9 .

IS $(43-2,65 \mathrm{~cm})$ : A hyalopilitic tractyyte with microphenocrysts

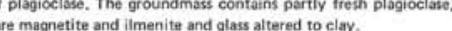
TS $(43.2,107 \mathrm{~cm})$ : A vesicular hyalopiliticic-pilotoxitic trachyte contains $4.1 \%$ plagioclase laths, $0.08-0.5 \mathrm{~mm}$ size, The groundmat attered to clay, 61.1\%, Vesicles cover 25\% of the surtane. 


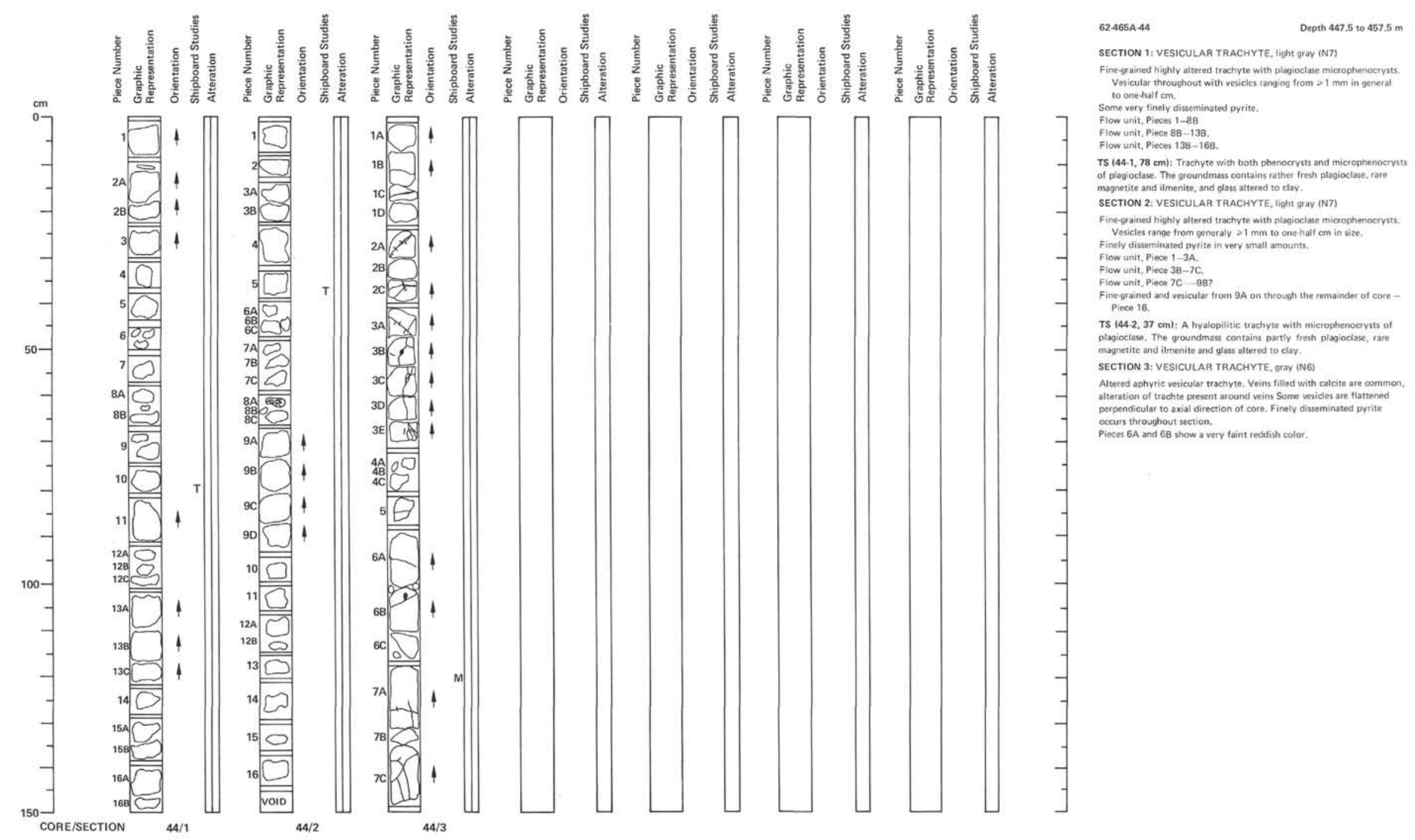




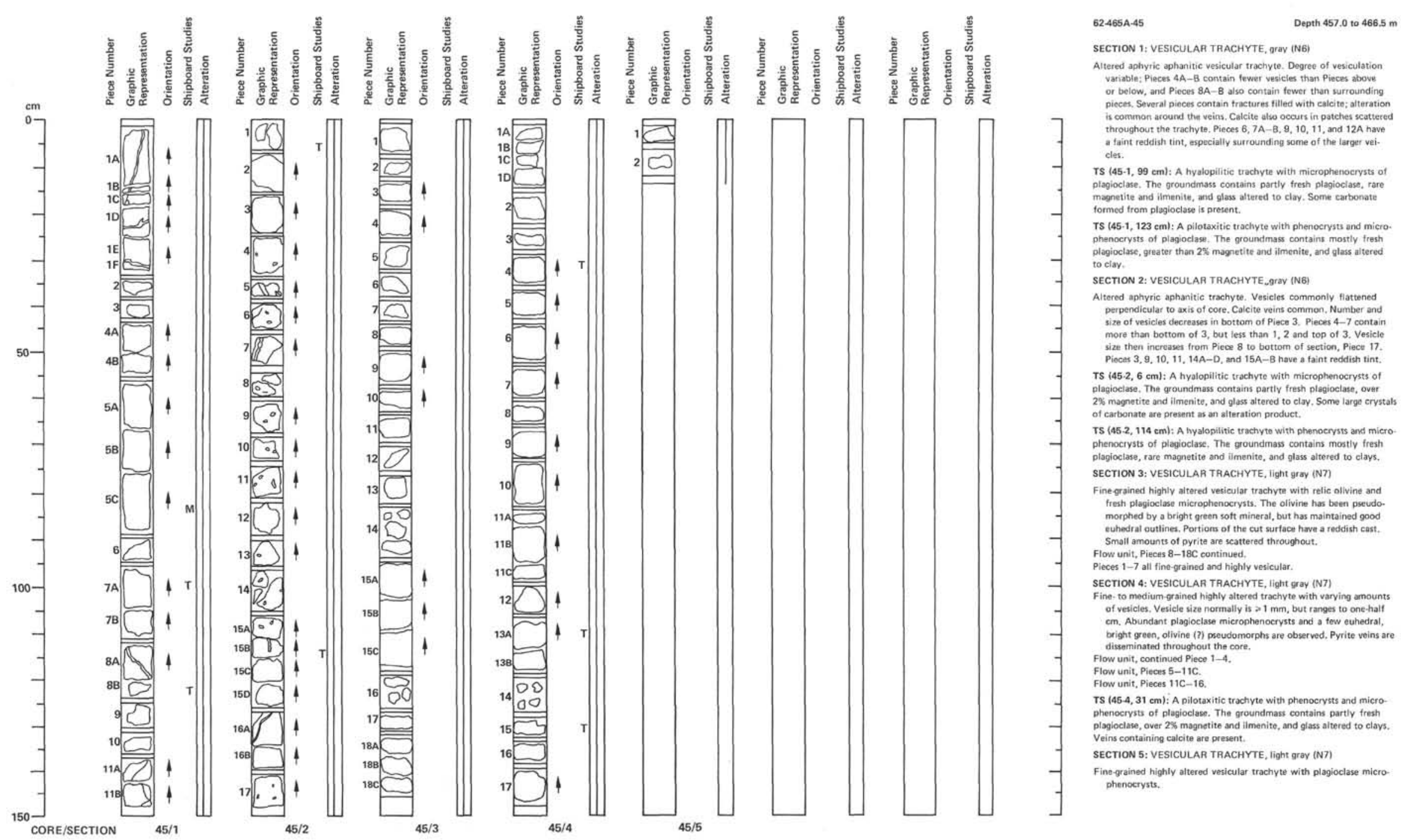




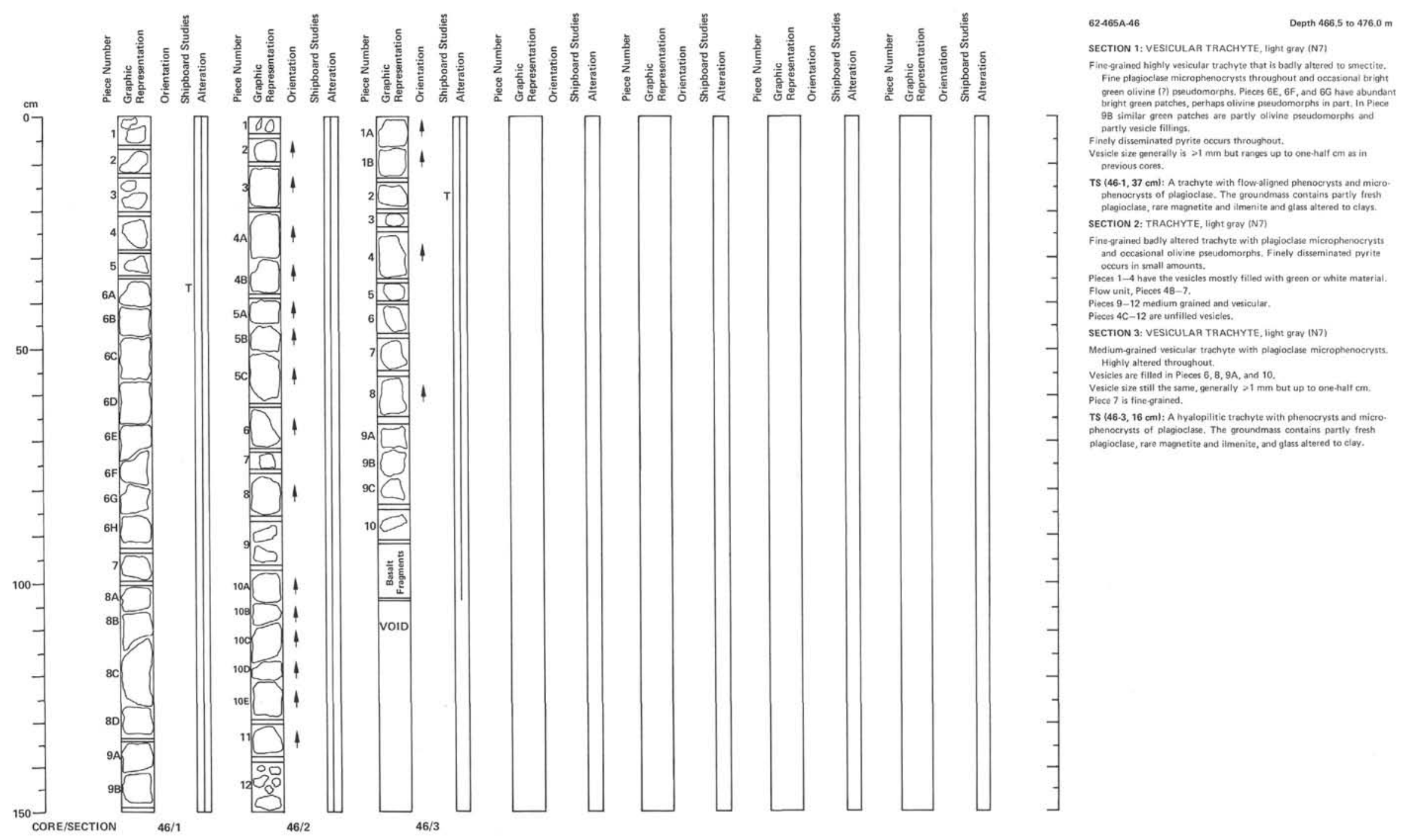


465-1

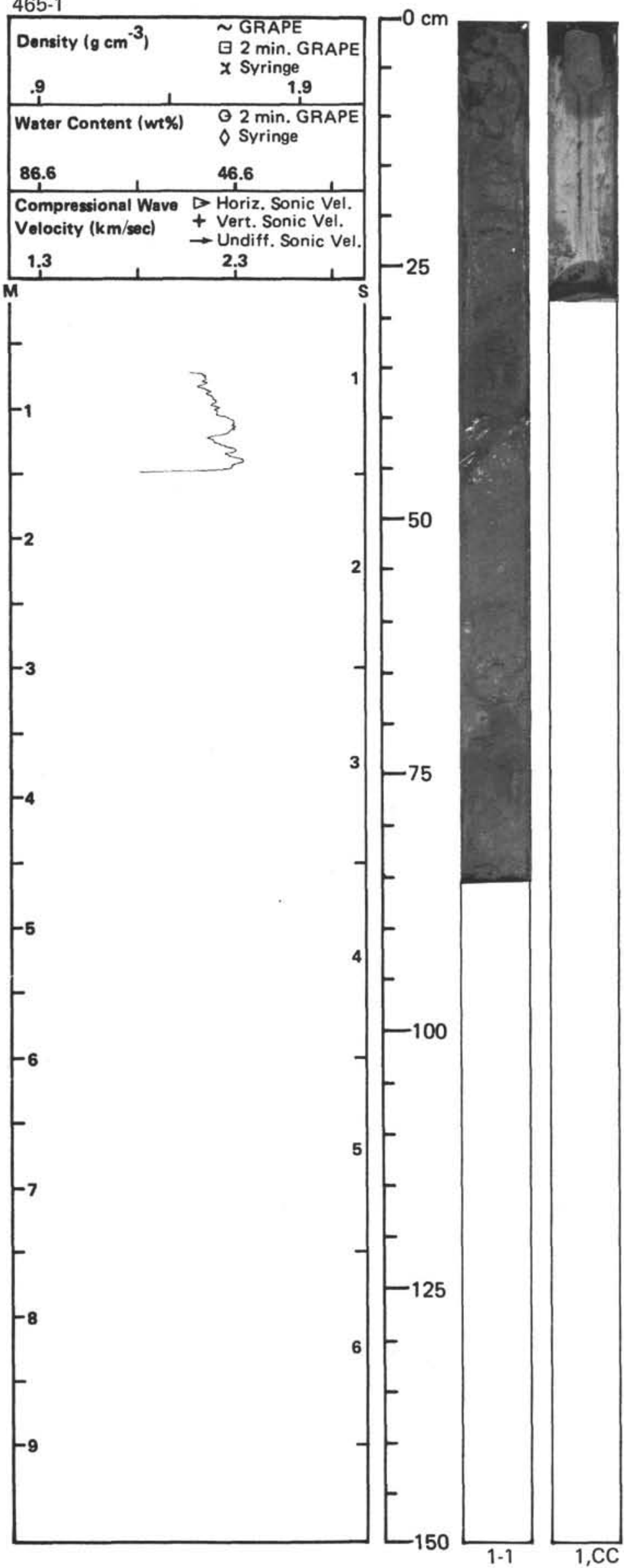




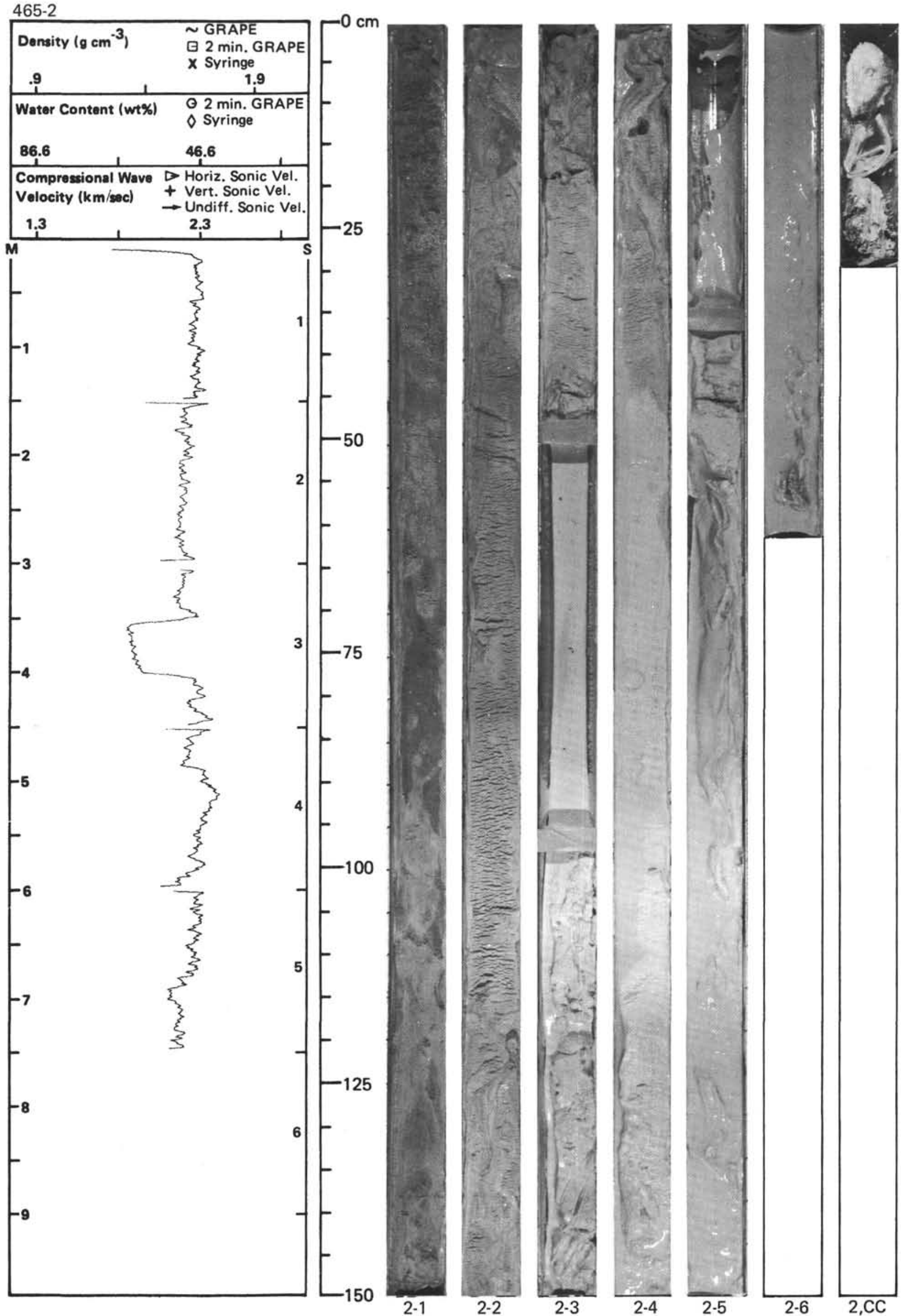


465-3

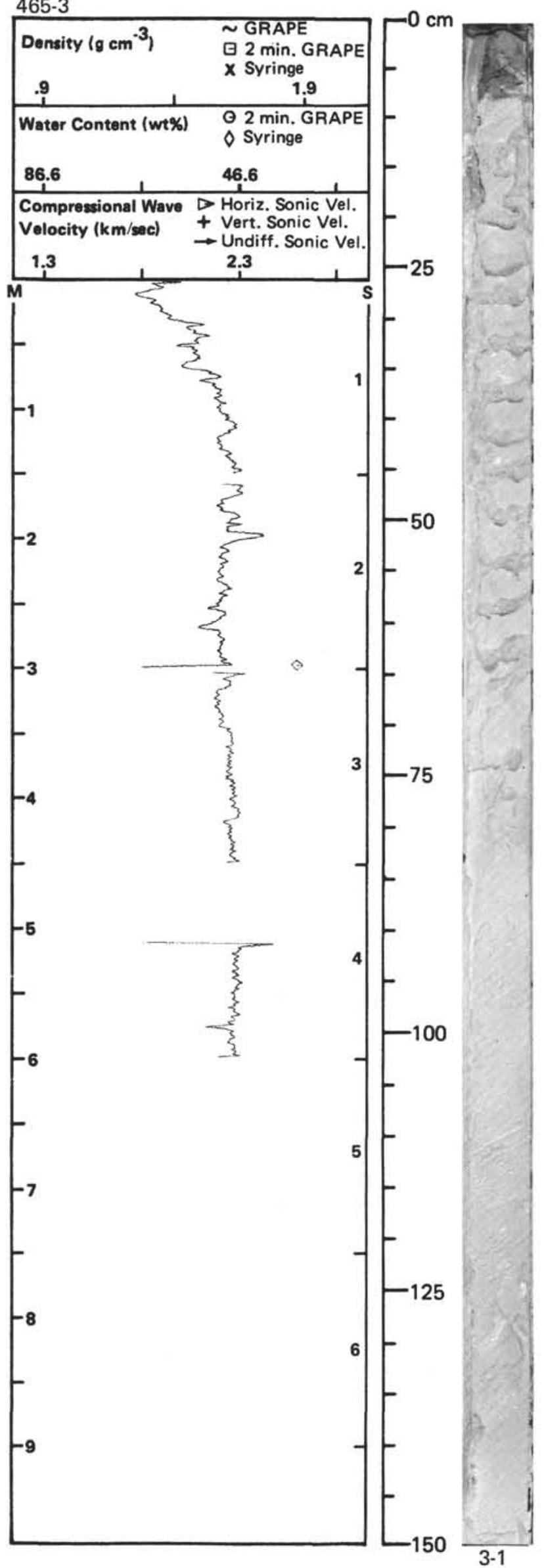

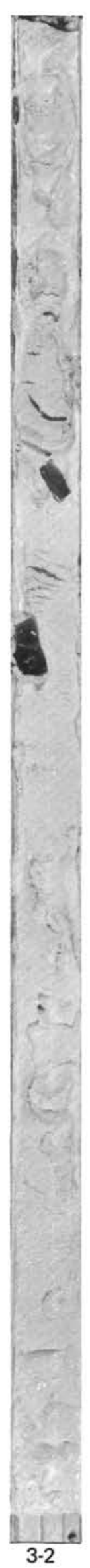
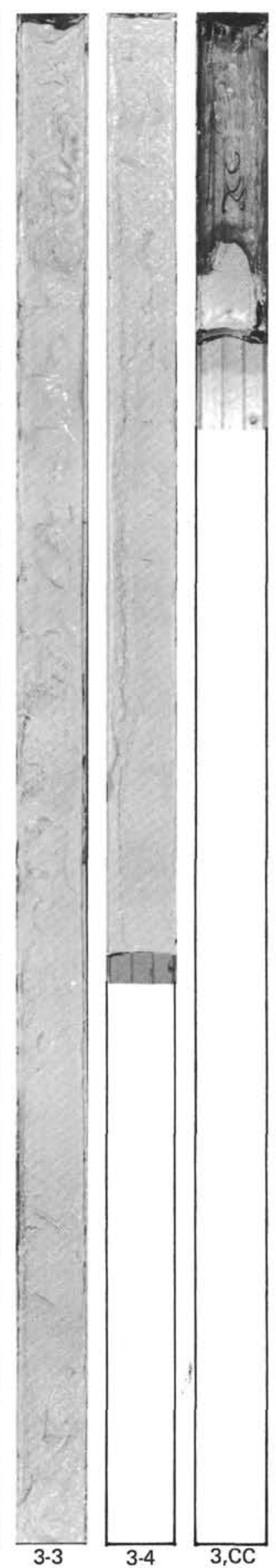


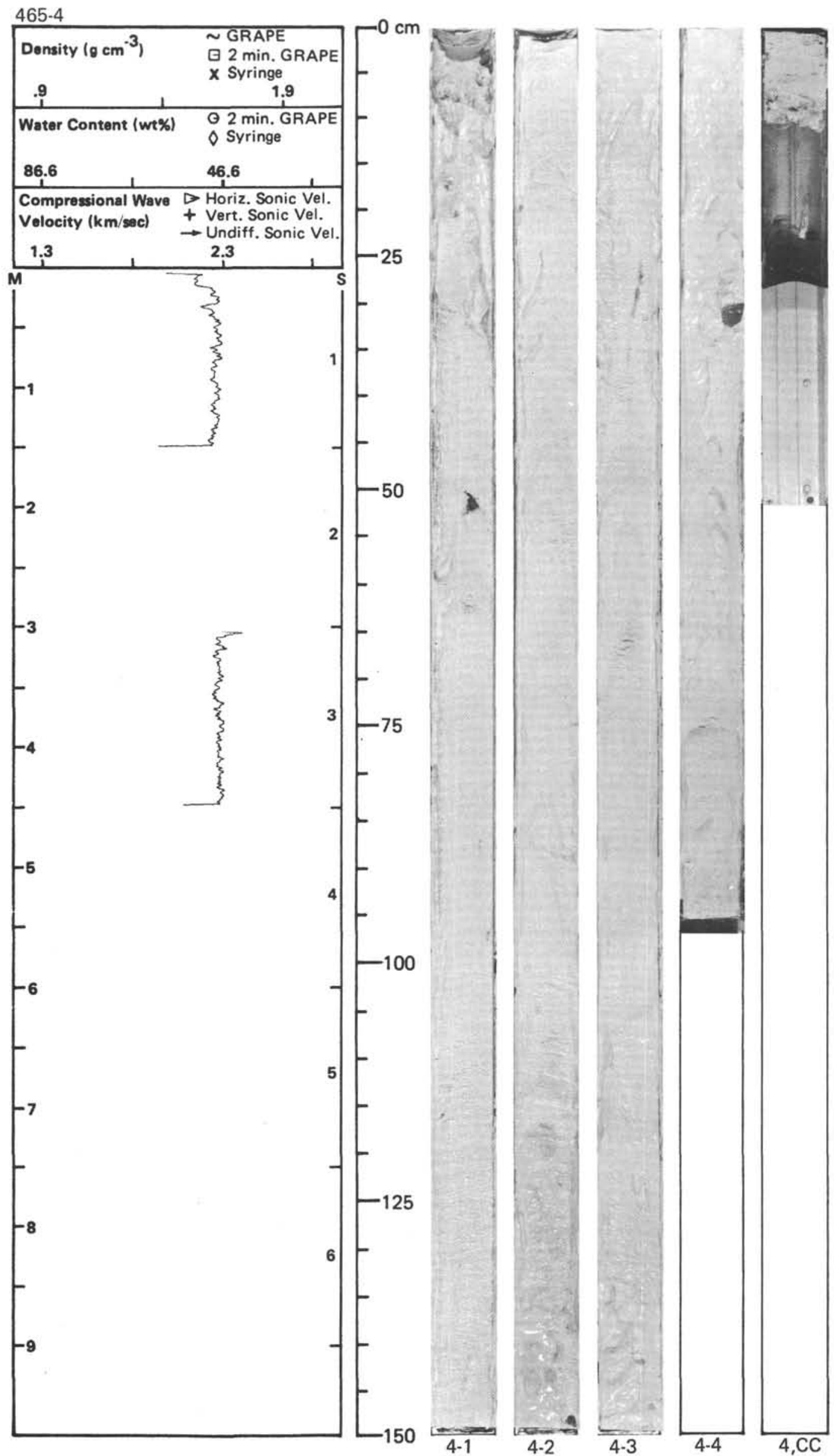



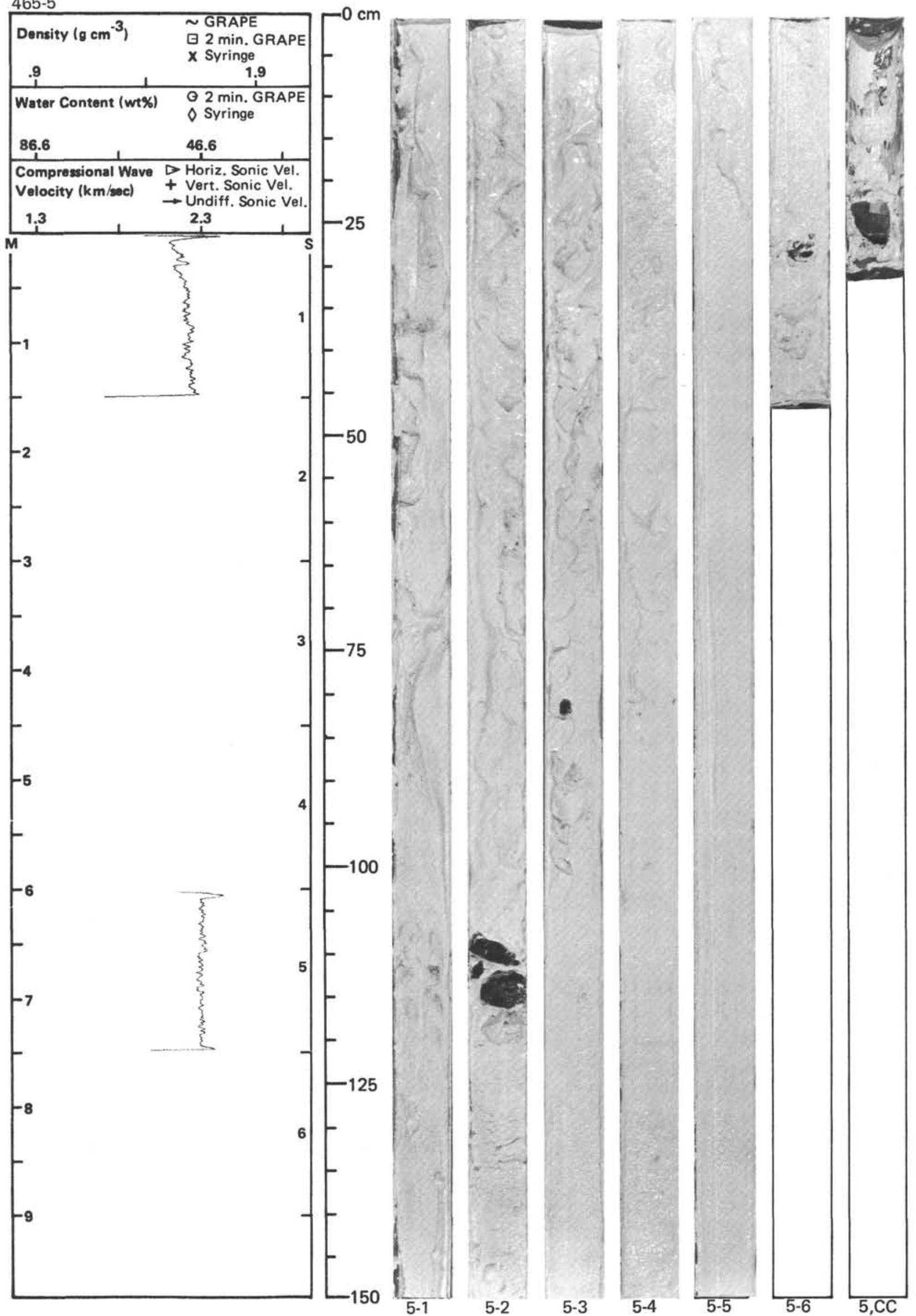


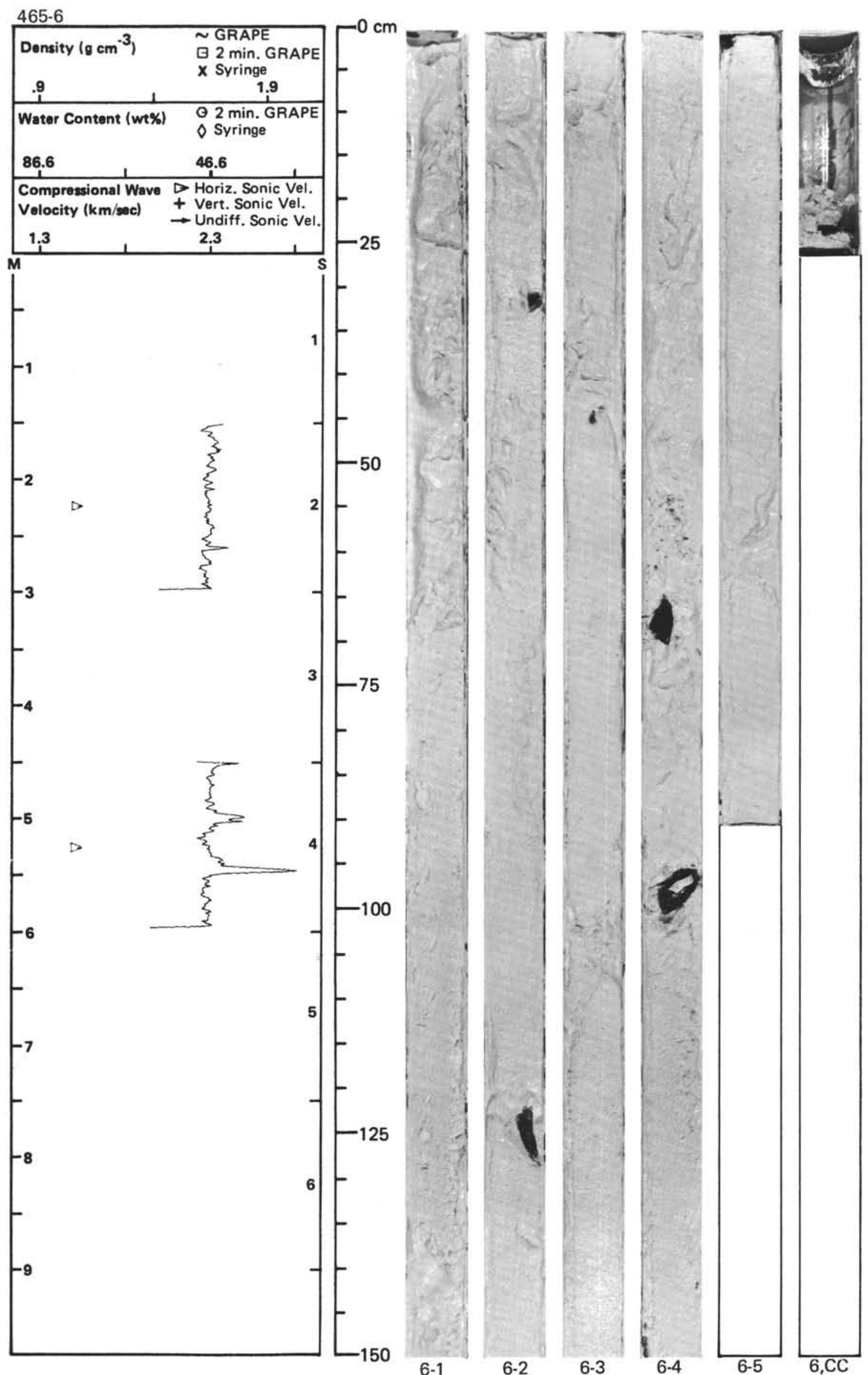



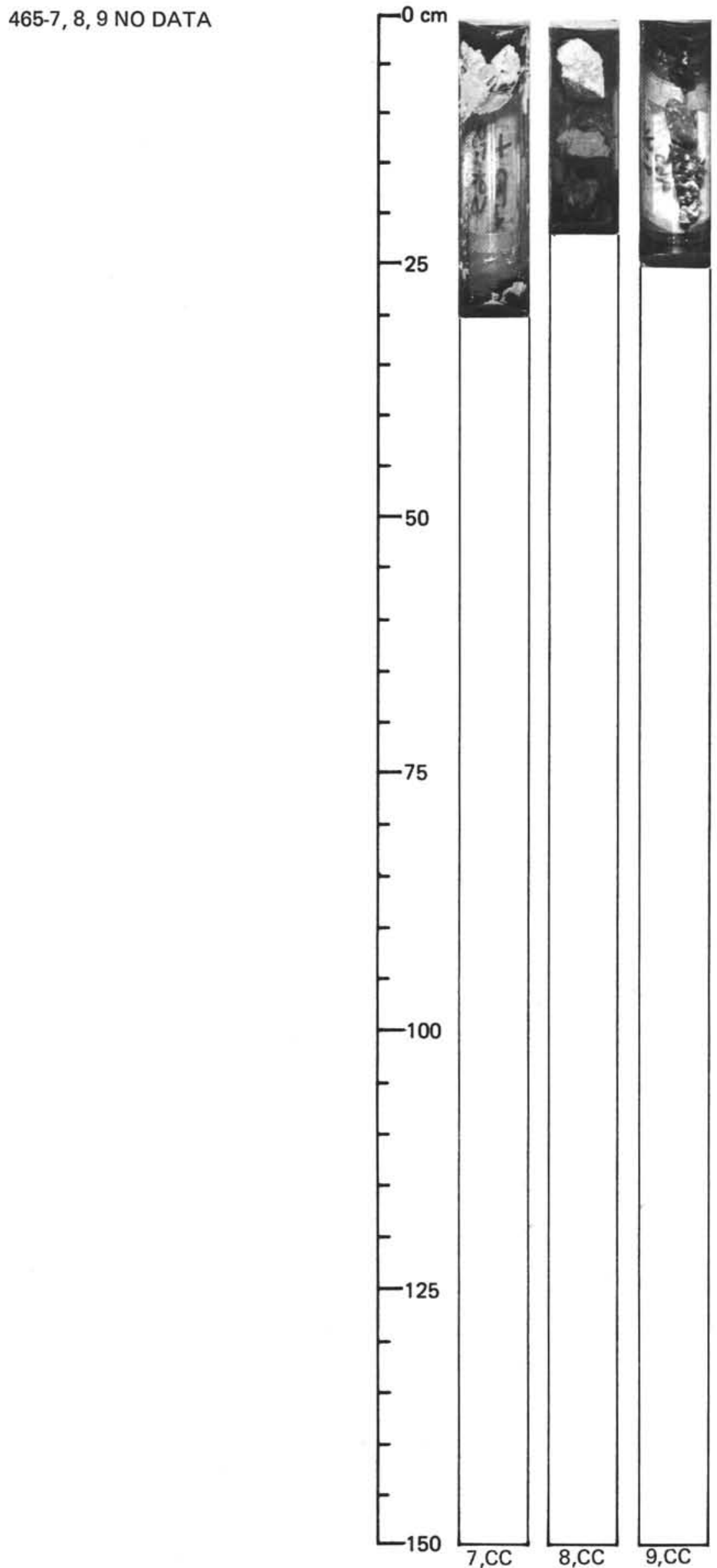


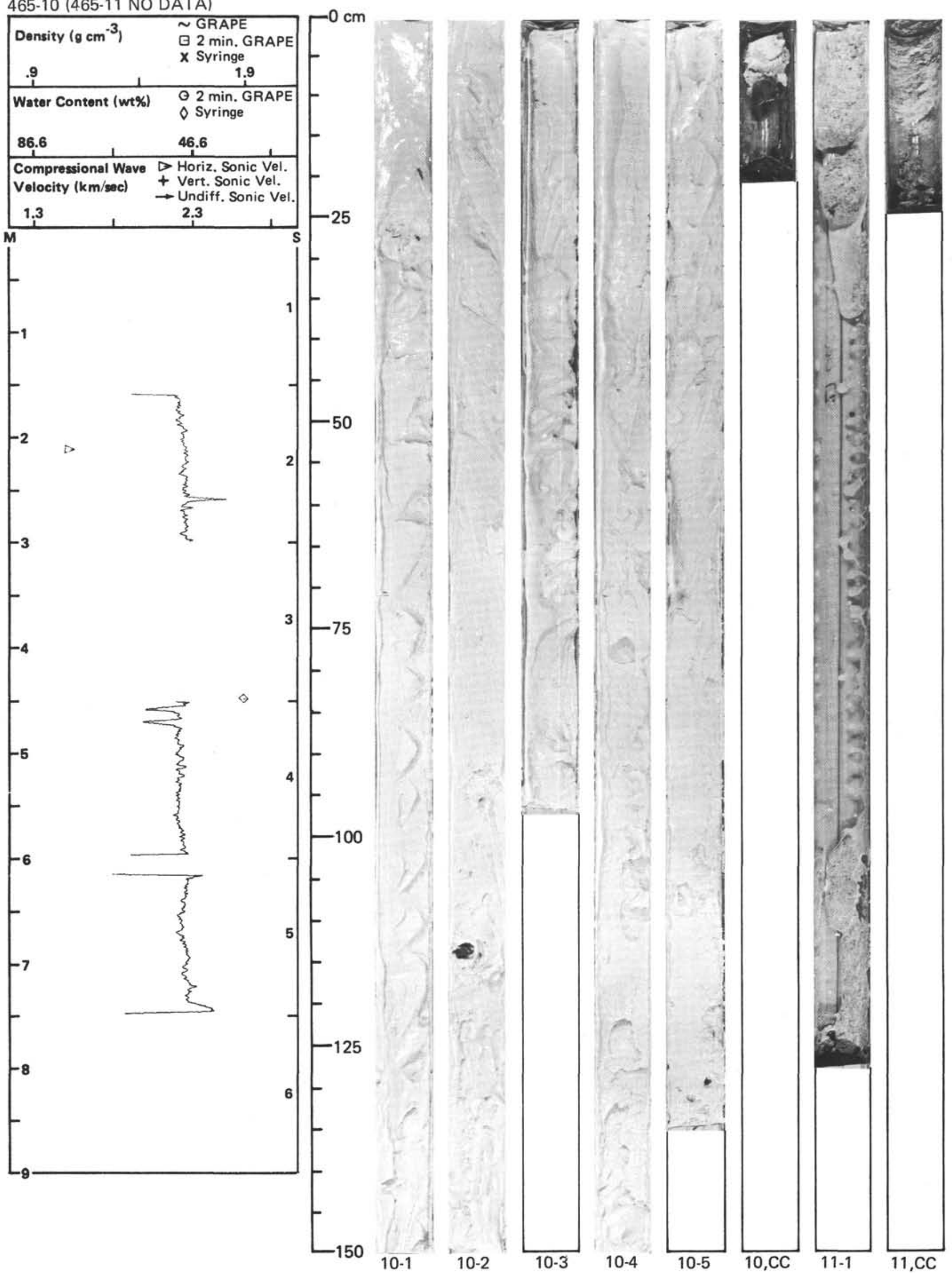




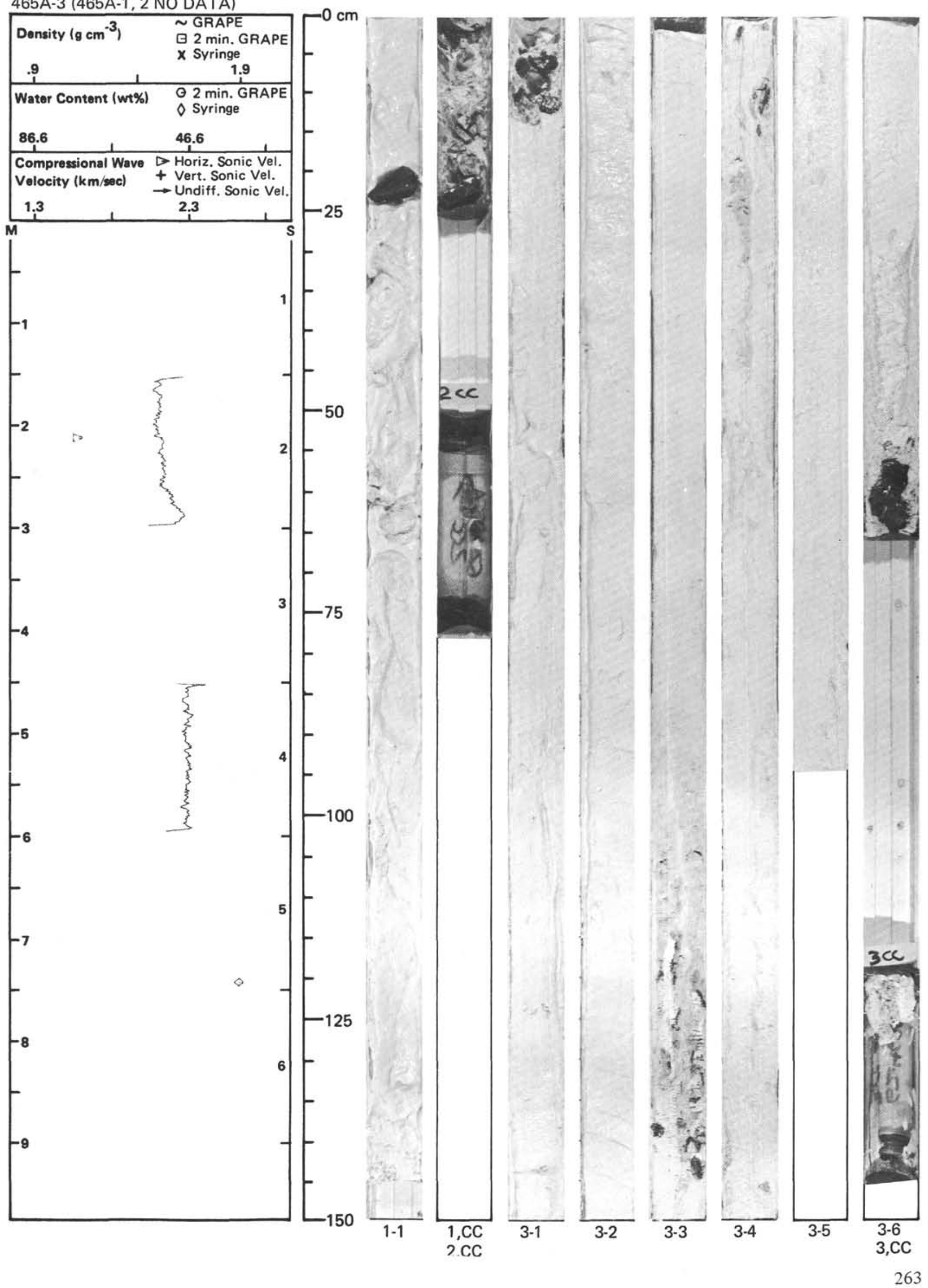


SITE 465

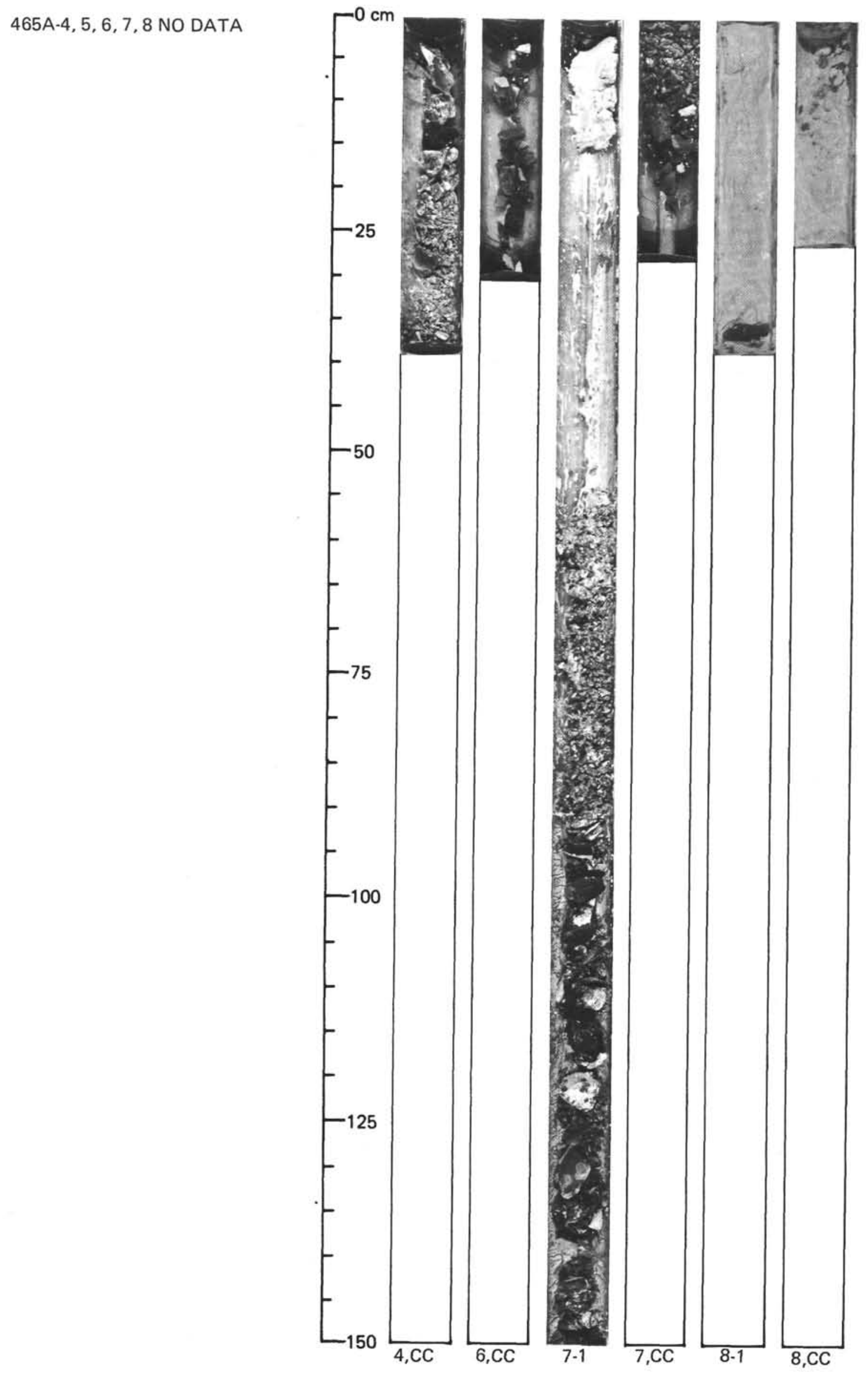


465A-9

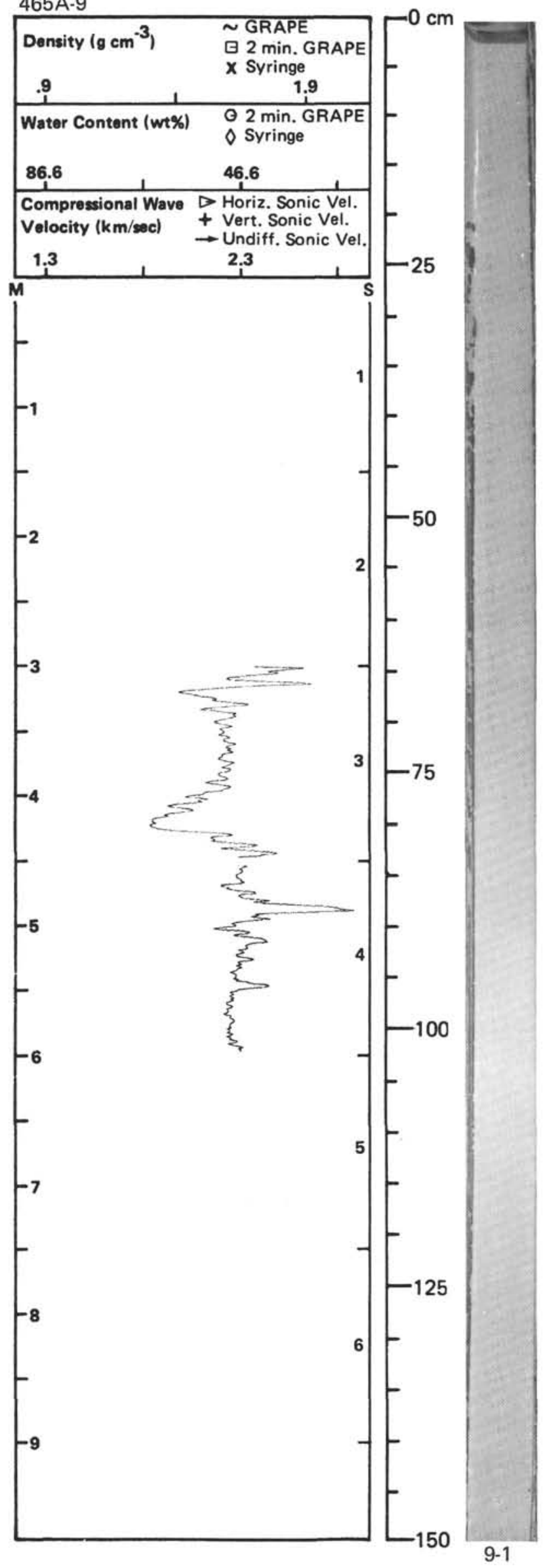

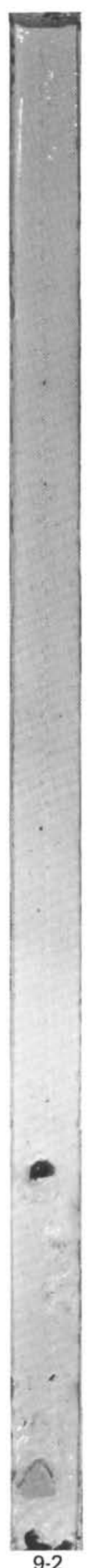

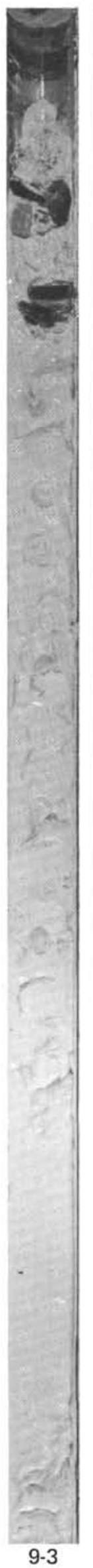

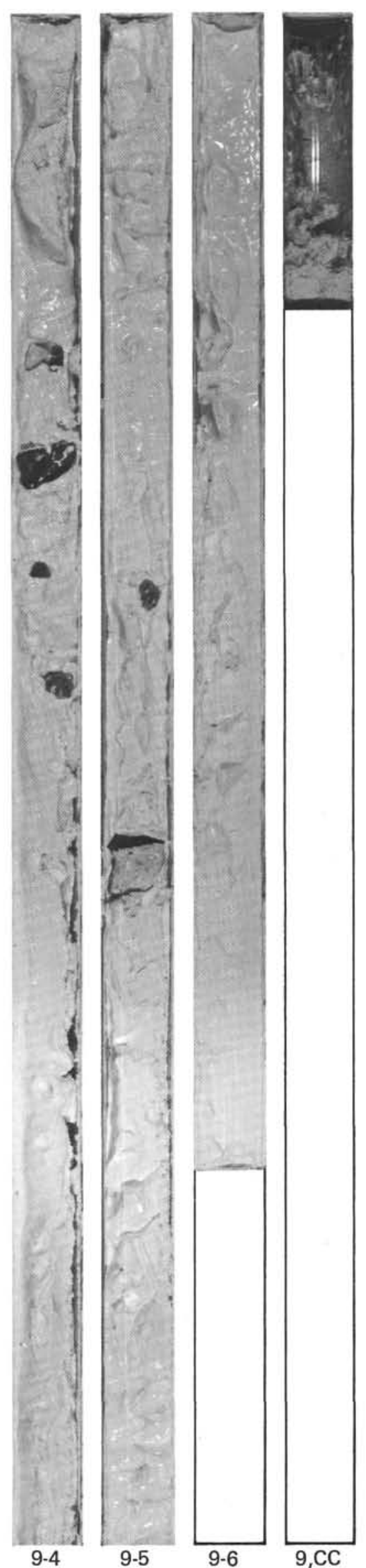




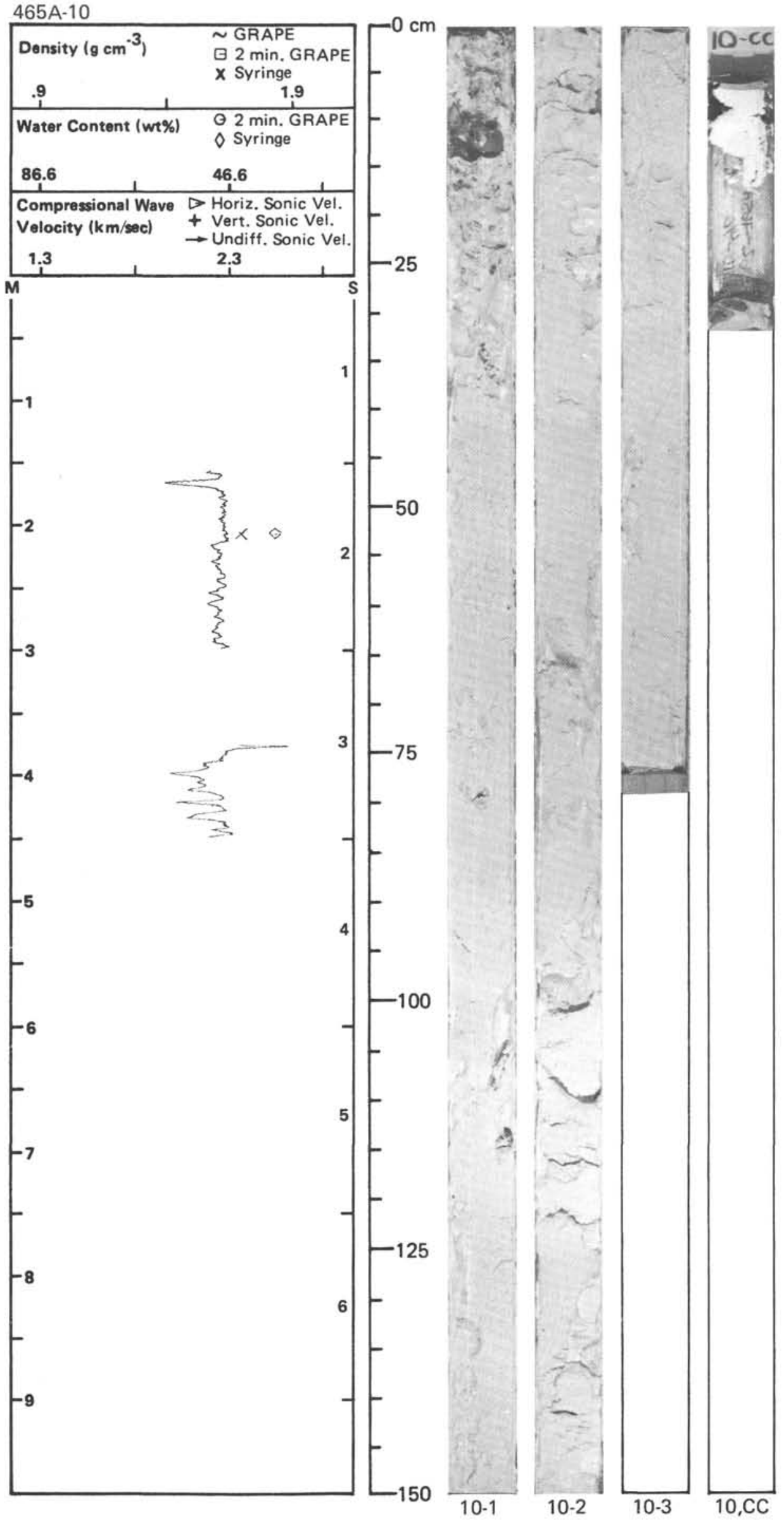


465A-11

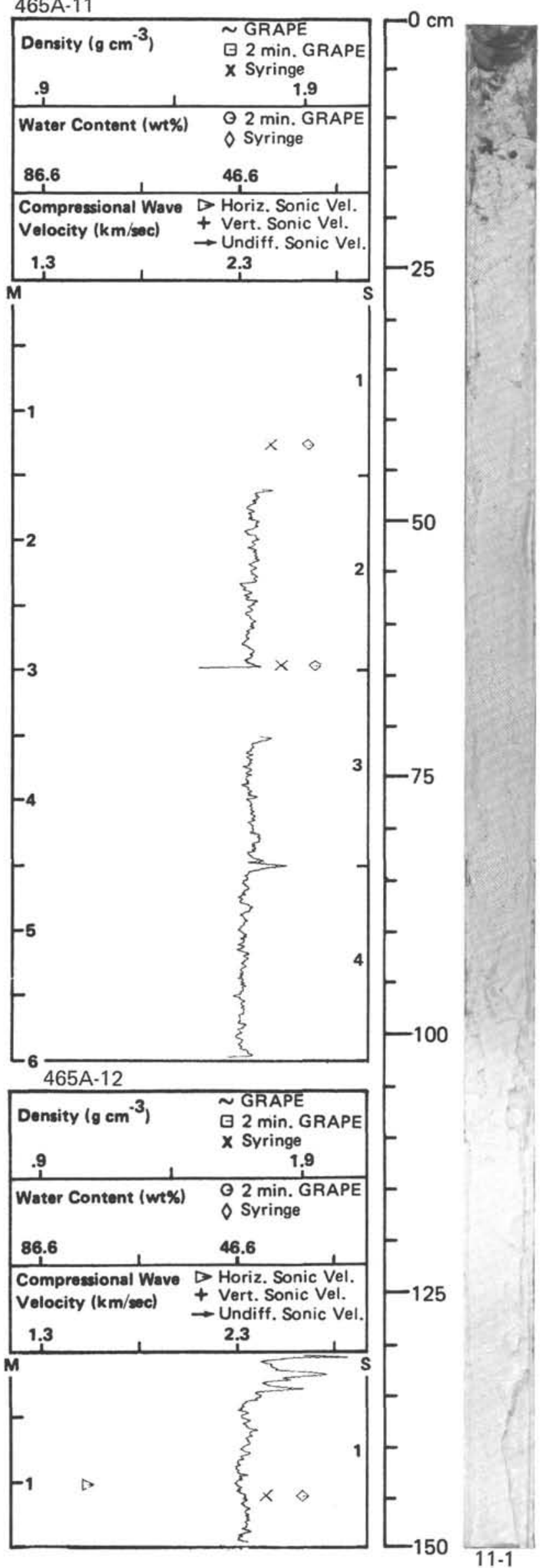

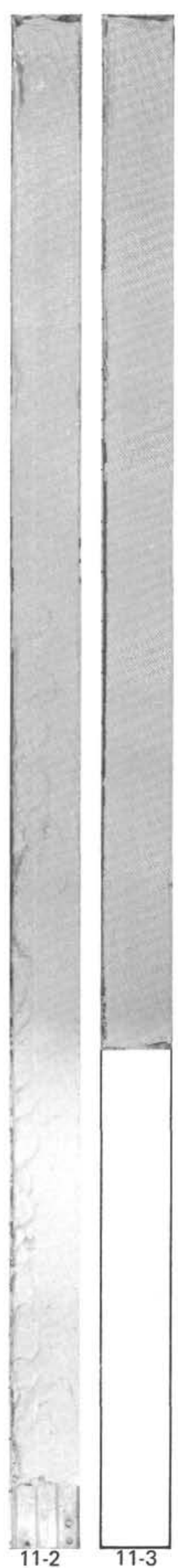
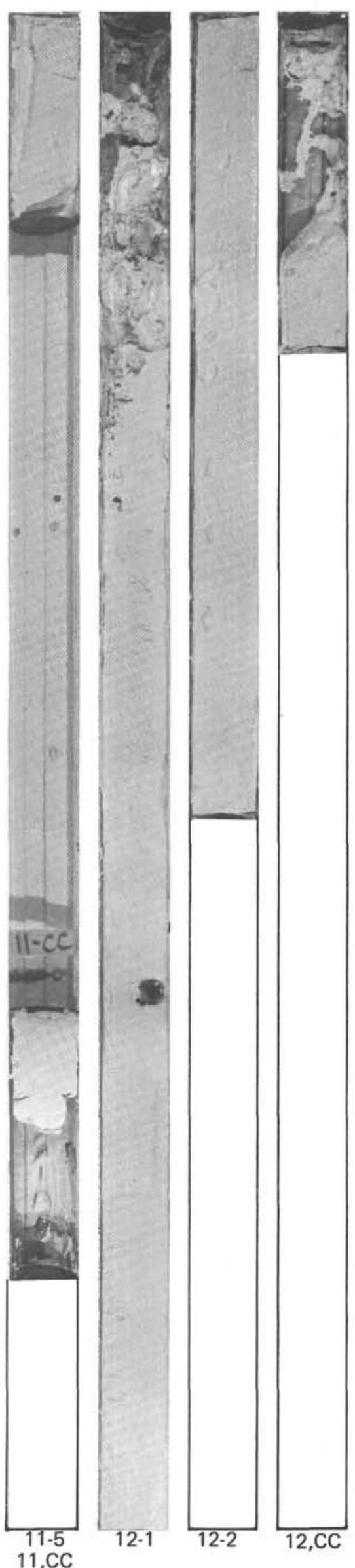
465A-15 (465A-13, 14 NO DATA)

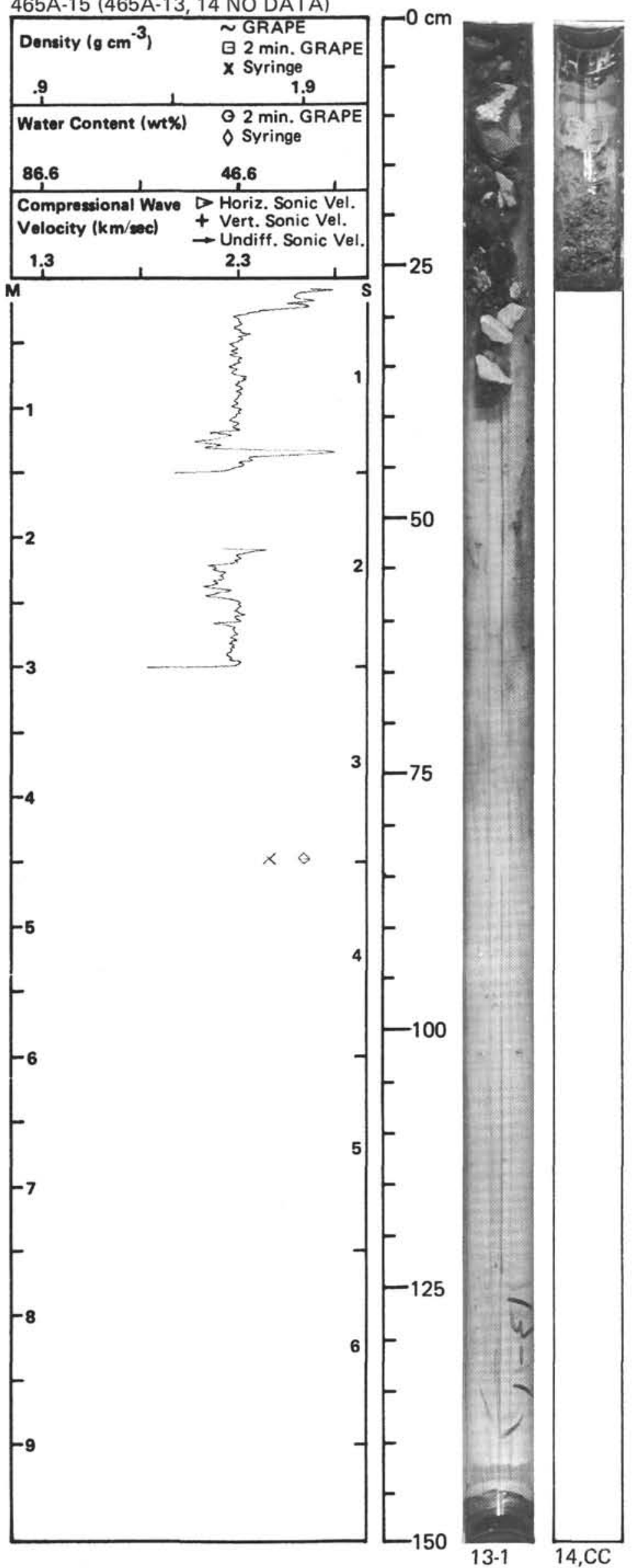

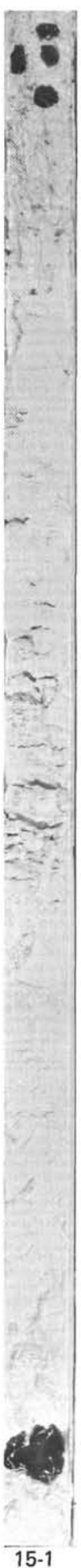
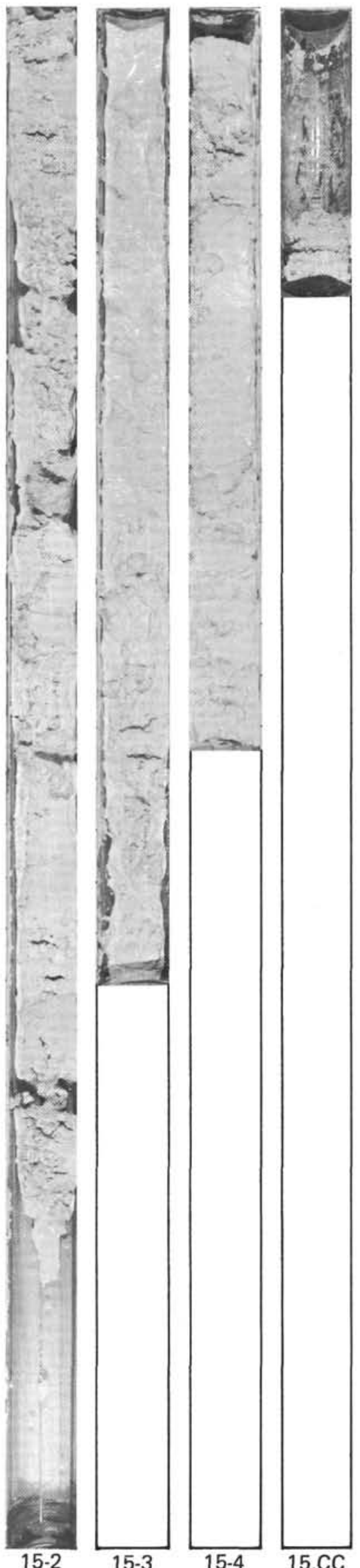
465A-16

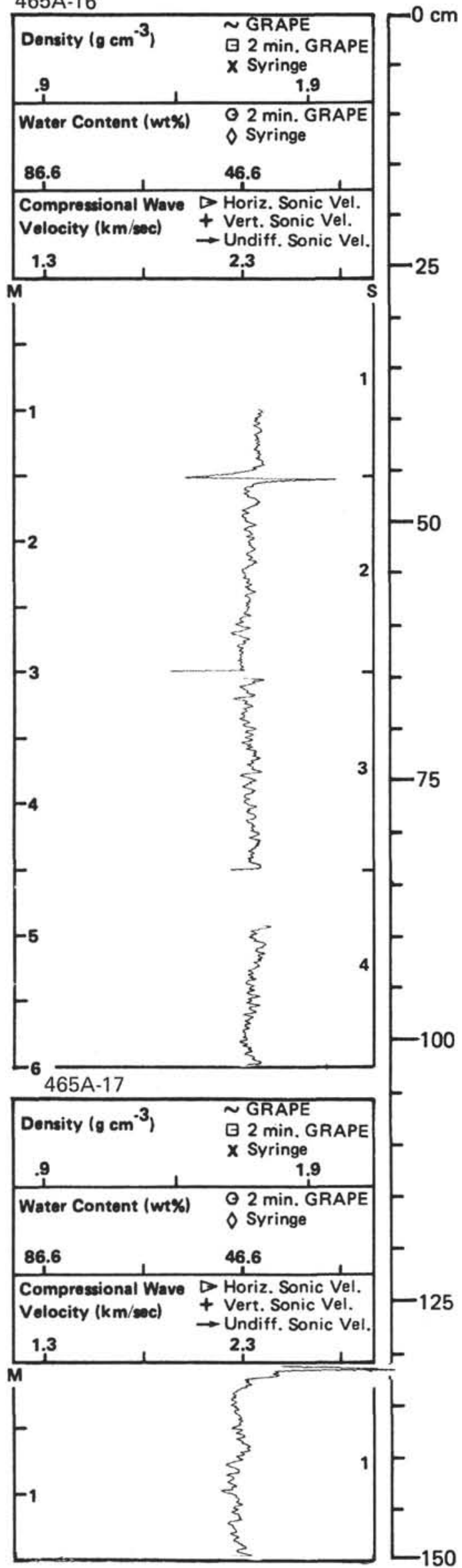

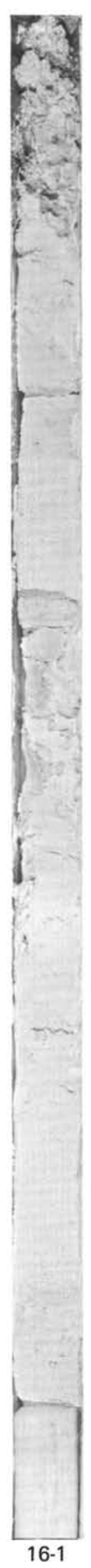
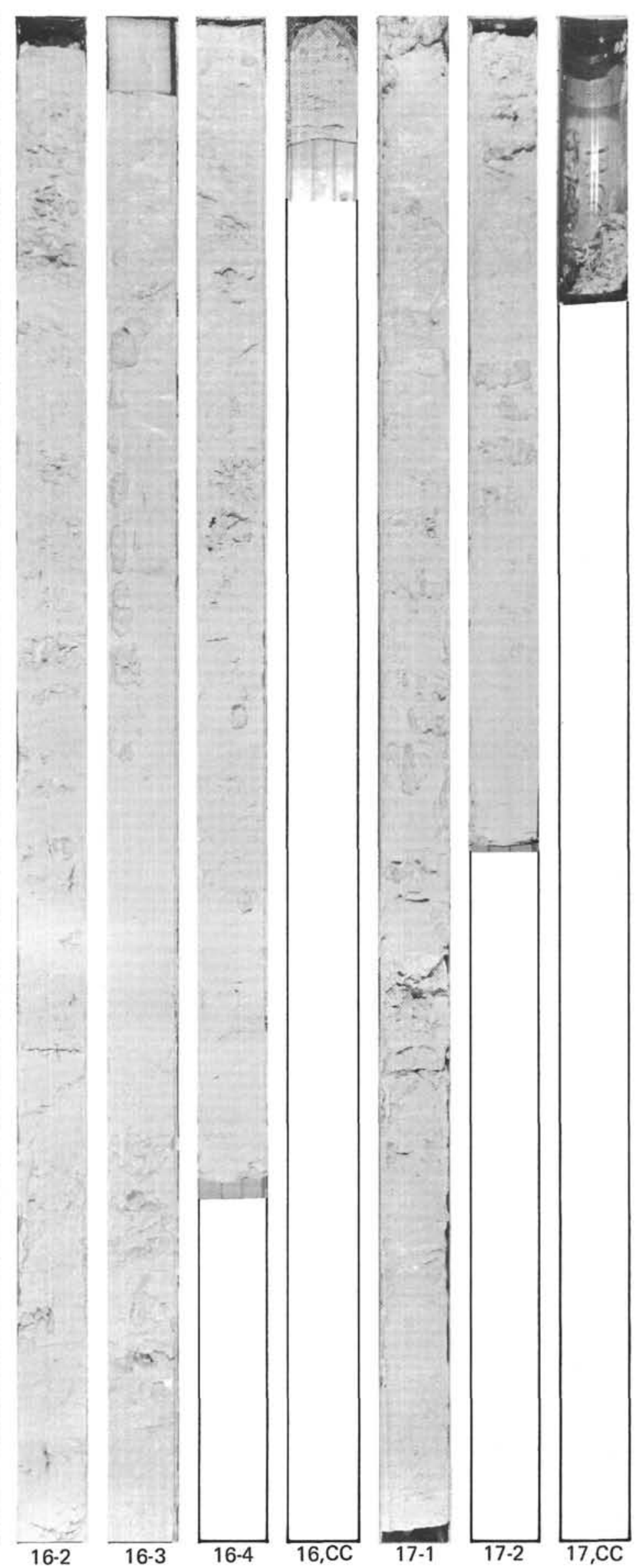
465A-18
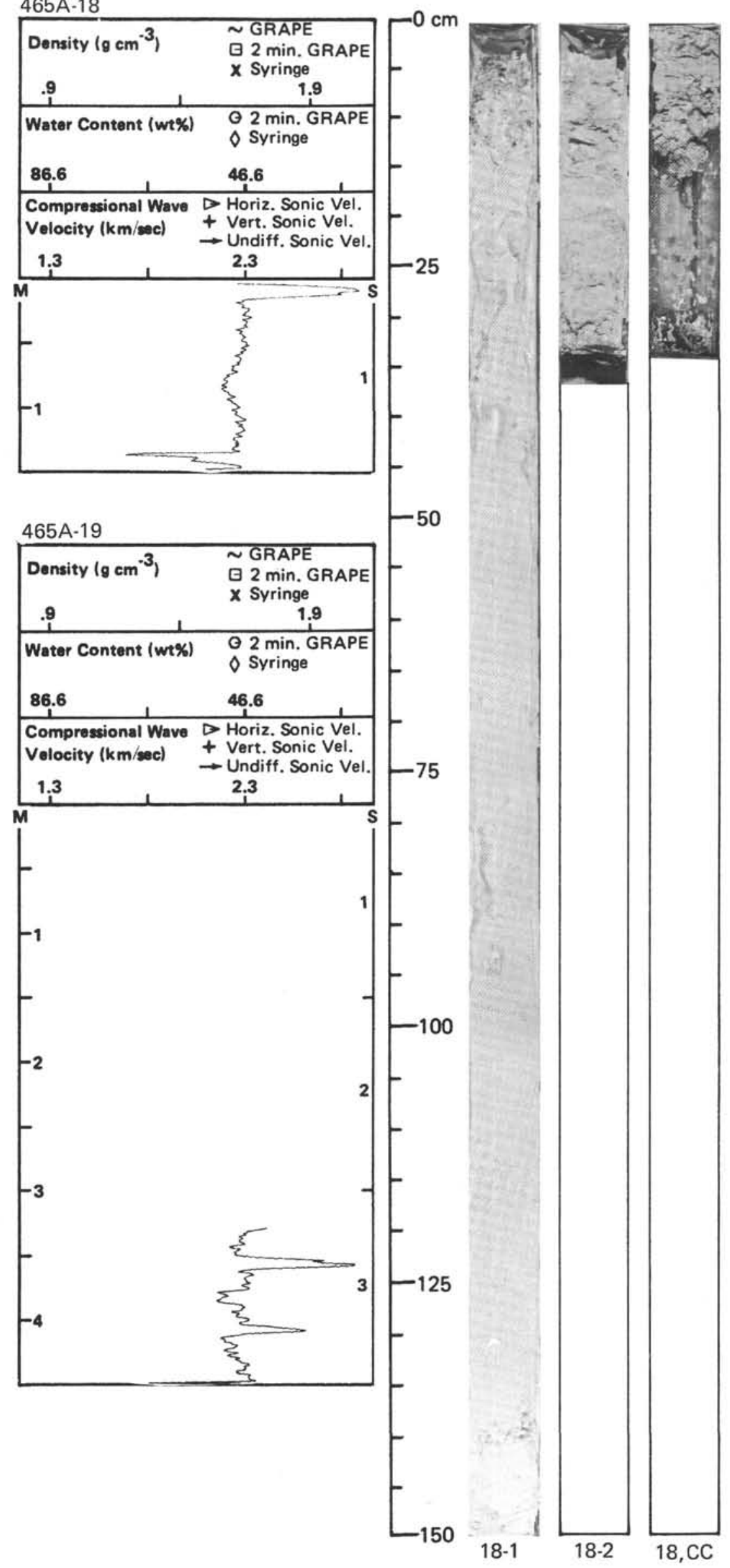
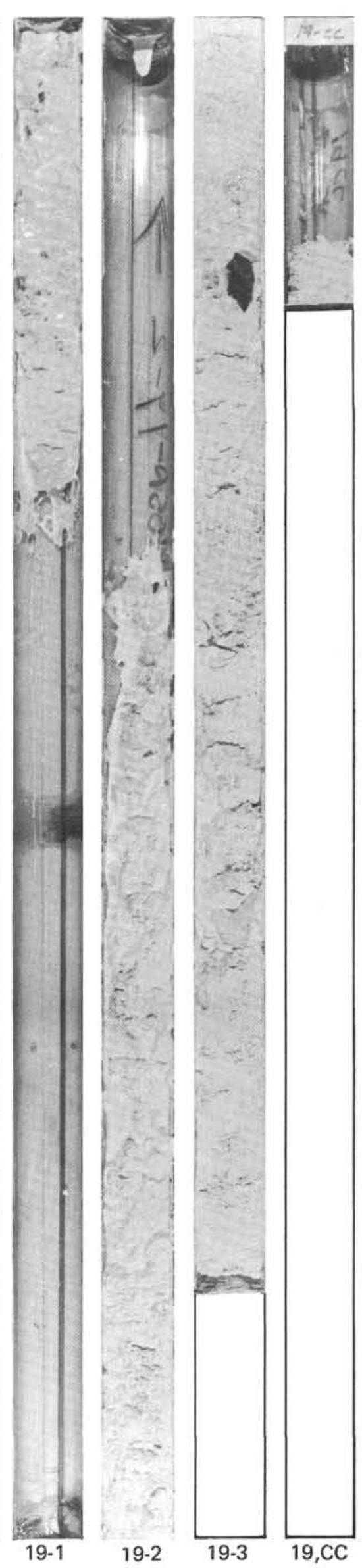

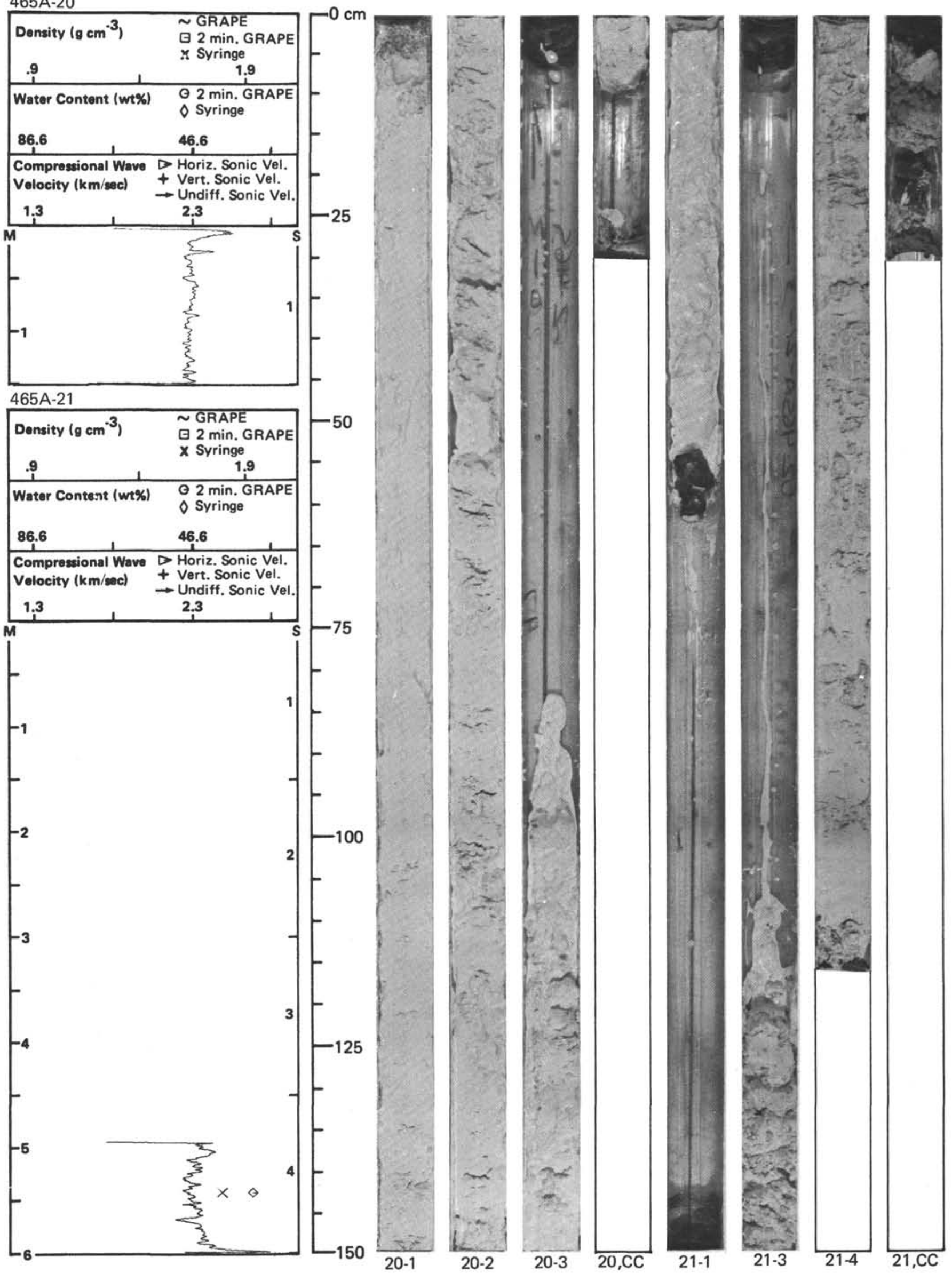


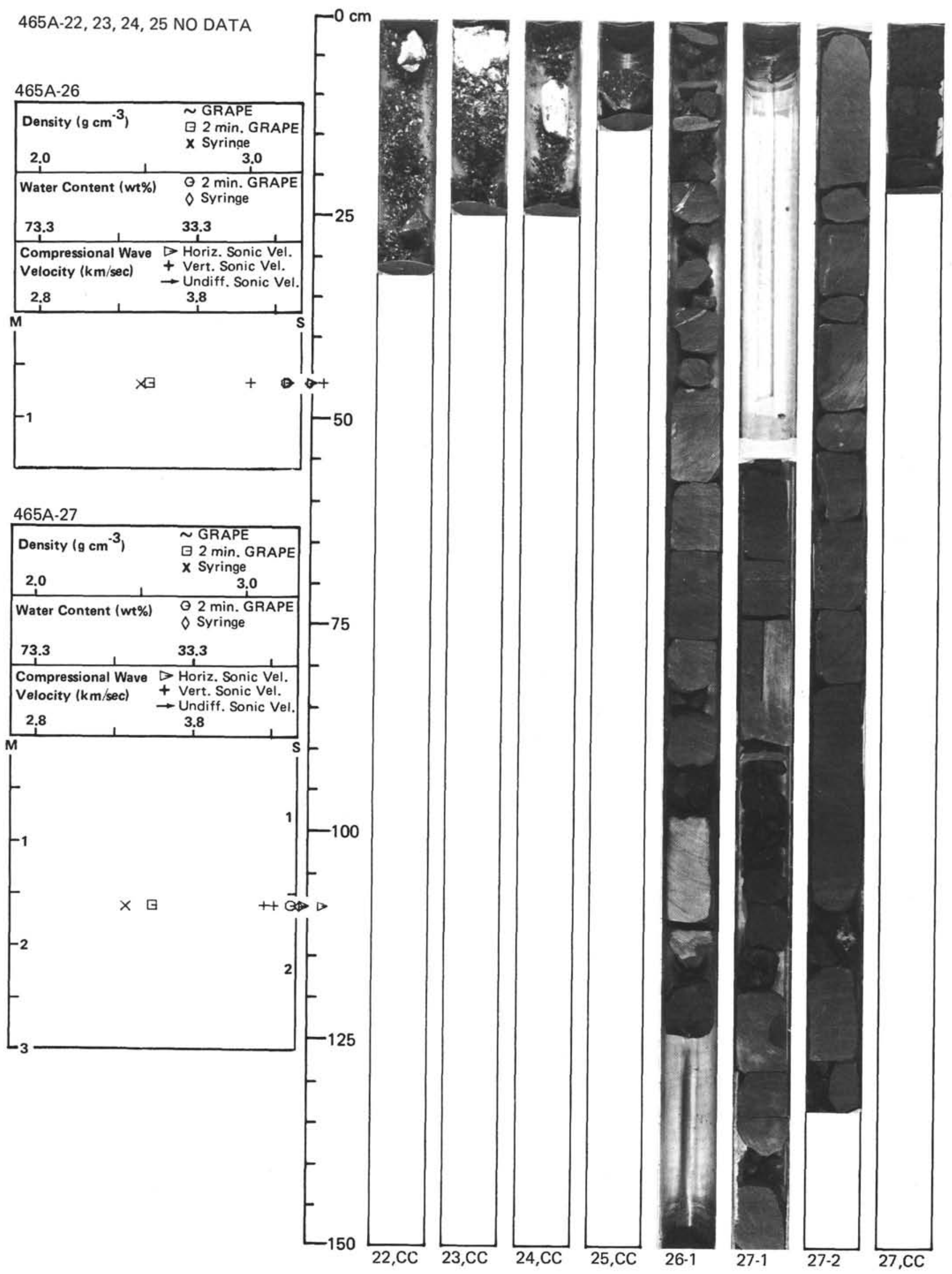




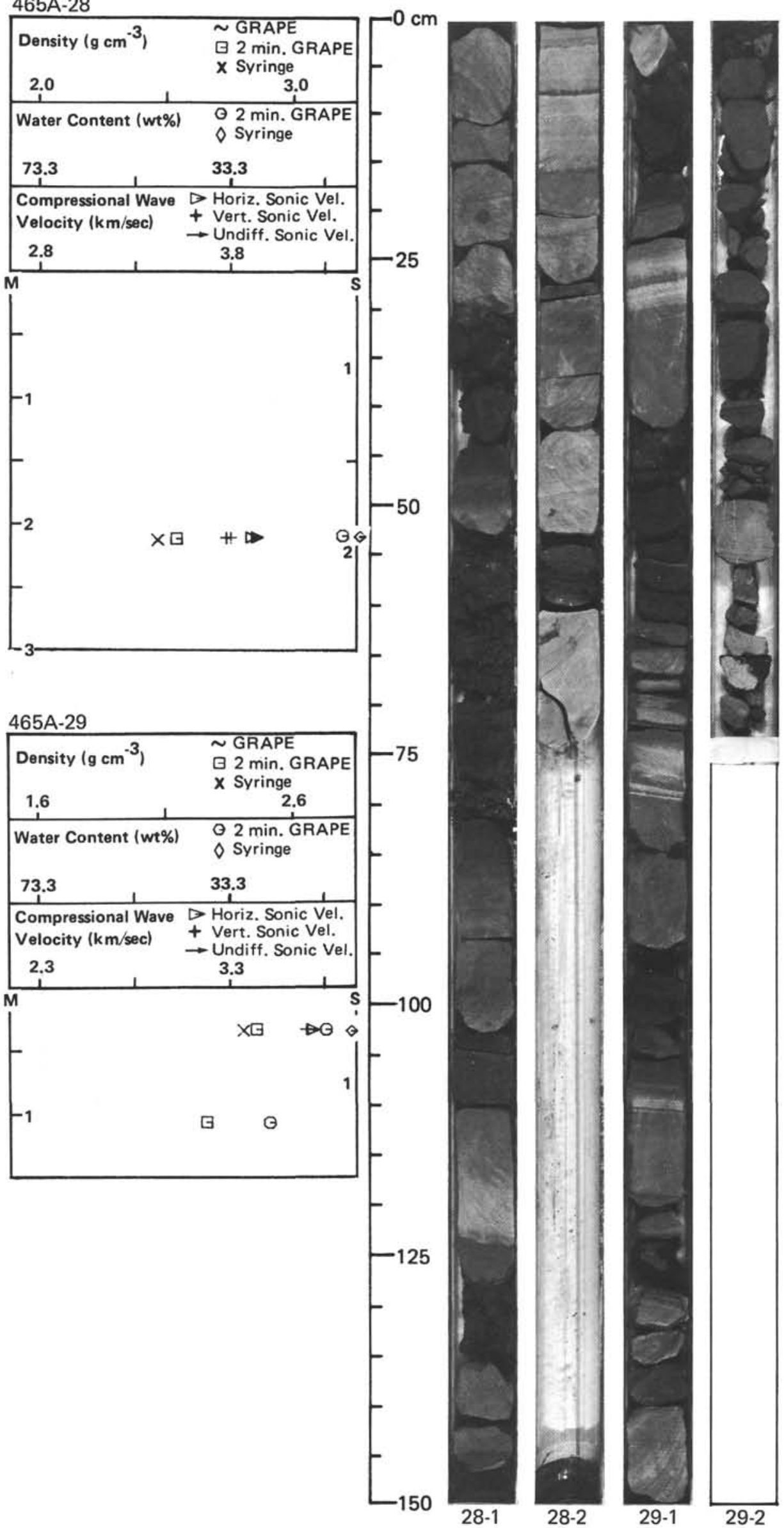




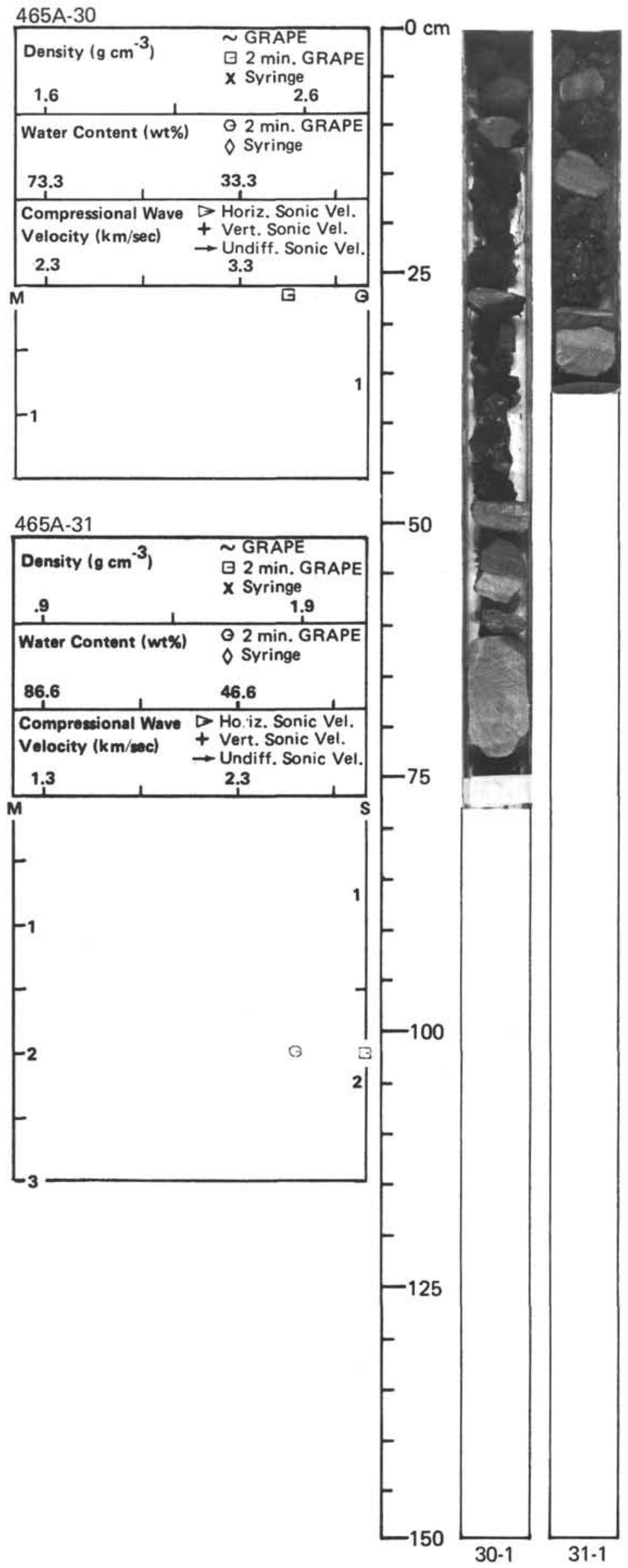


465A-32

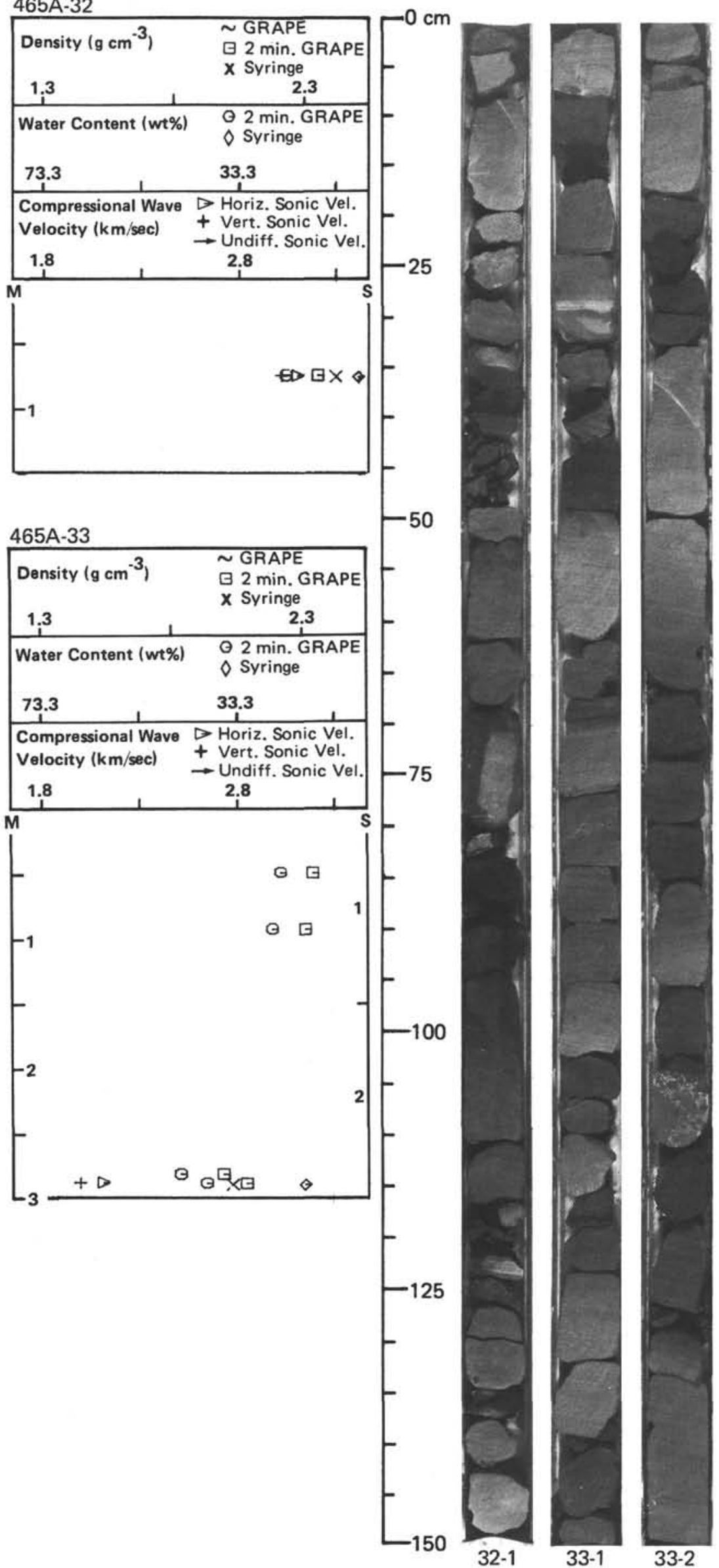




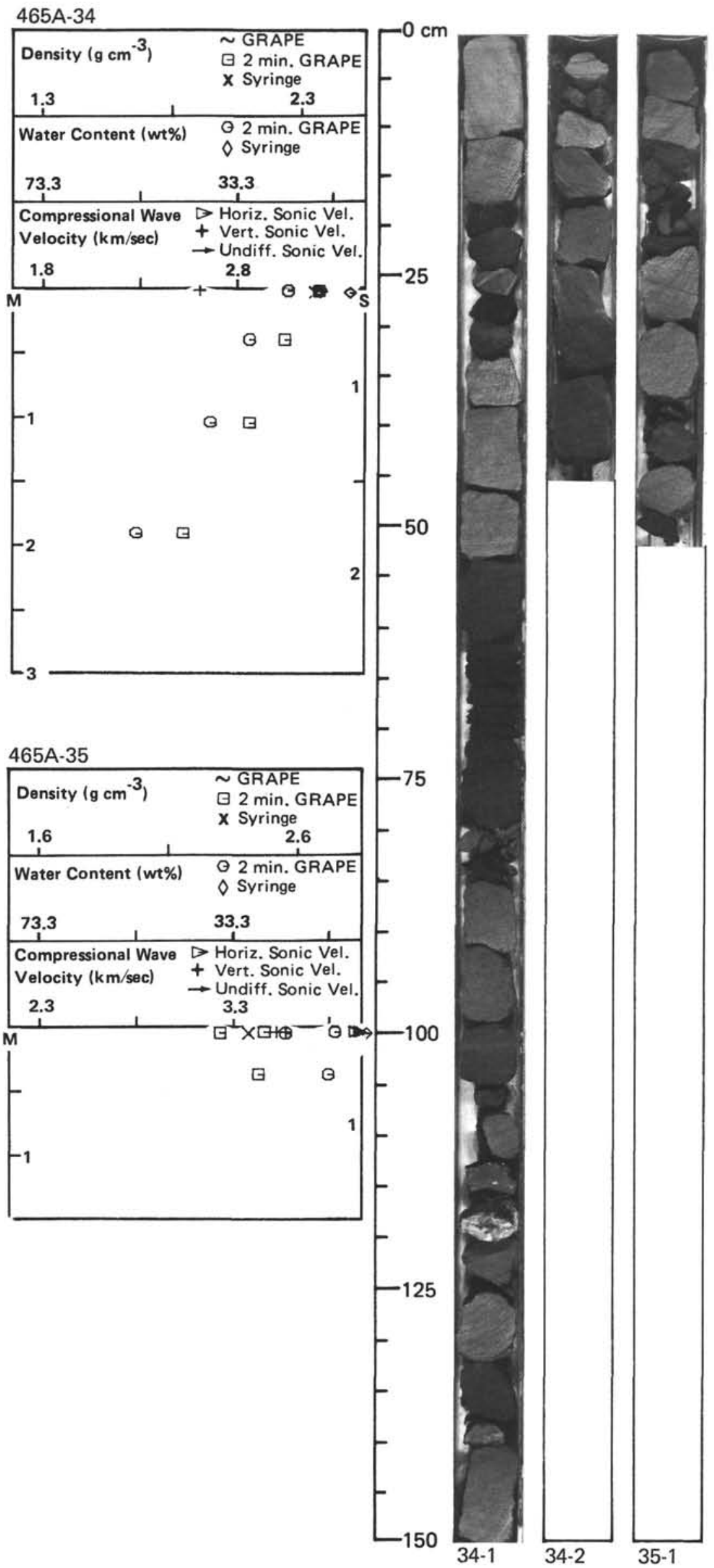


465A-36

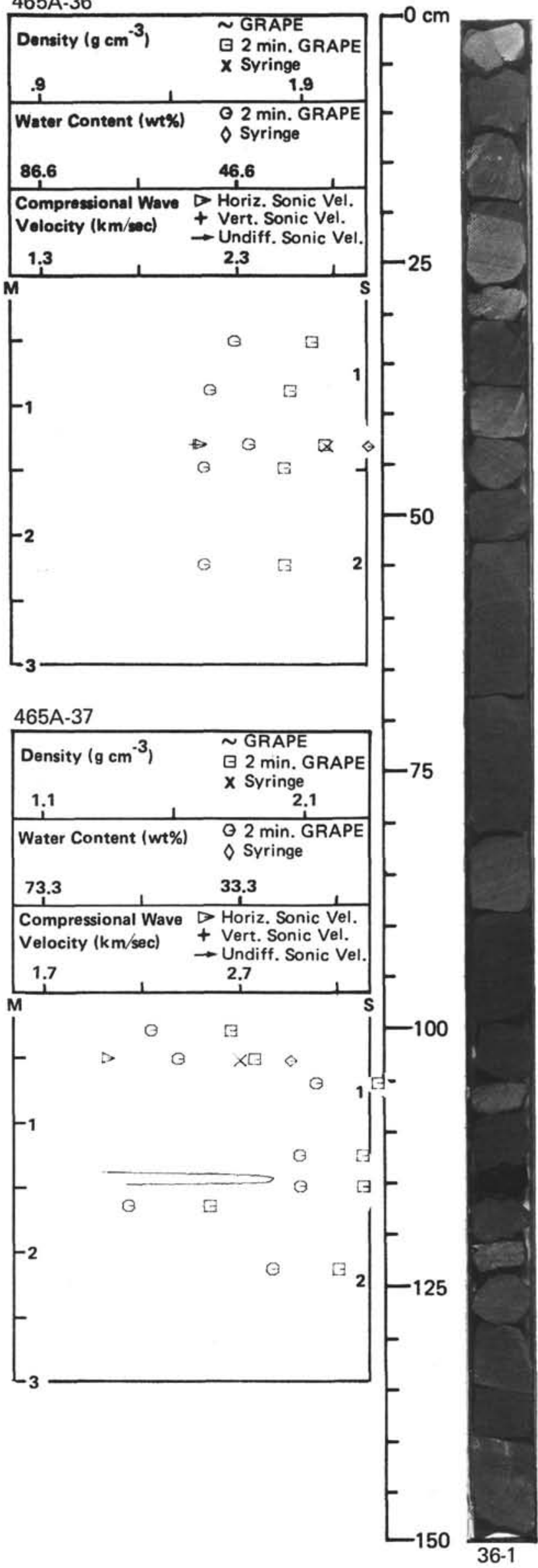

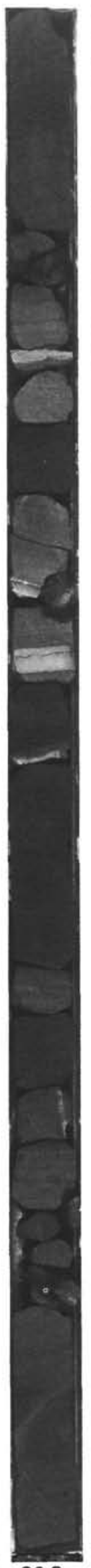
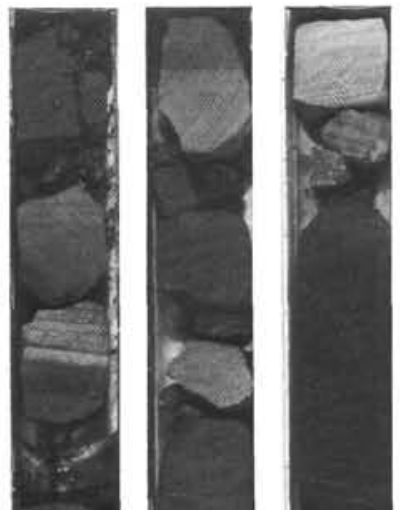

$$
8
$$

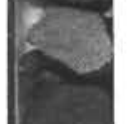




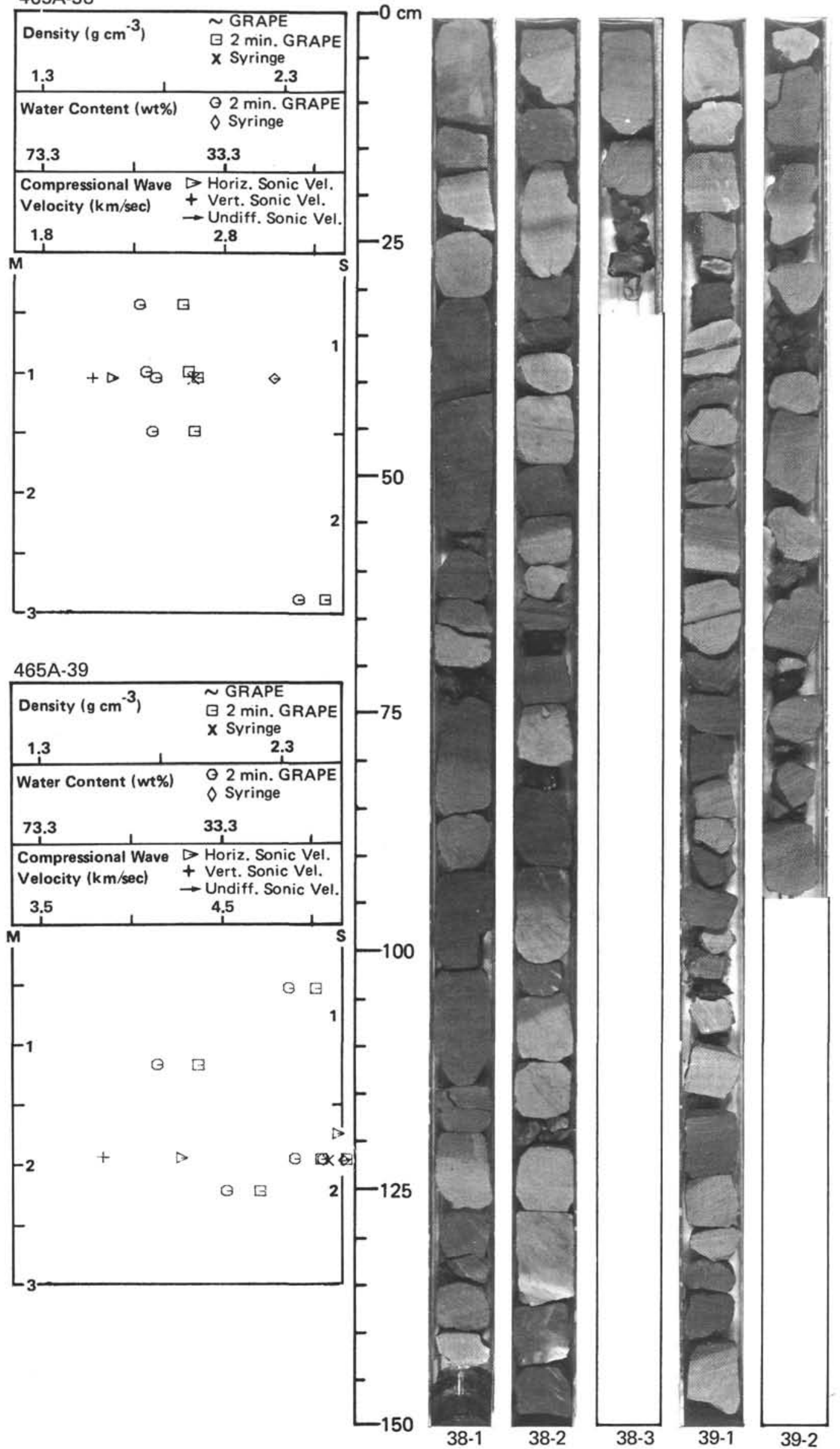


465A-40

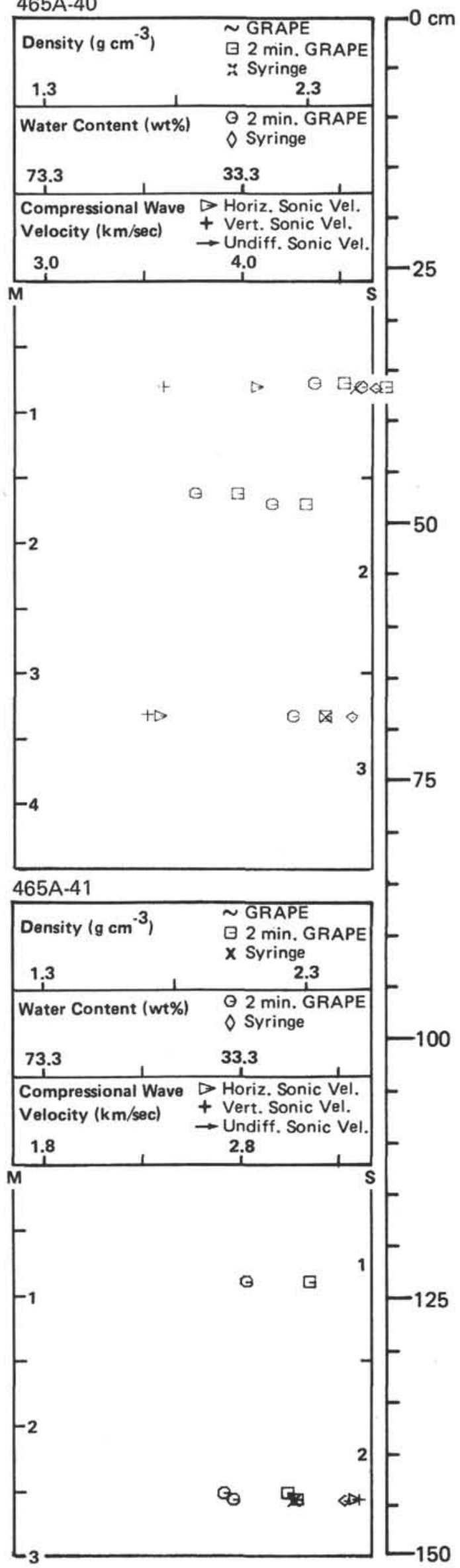

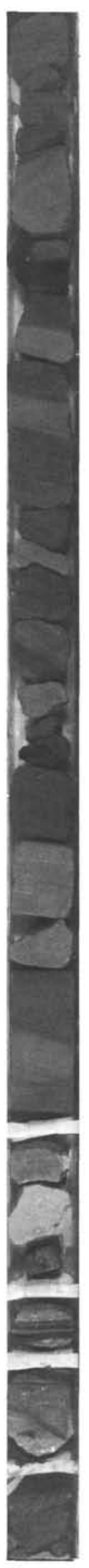

40-1
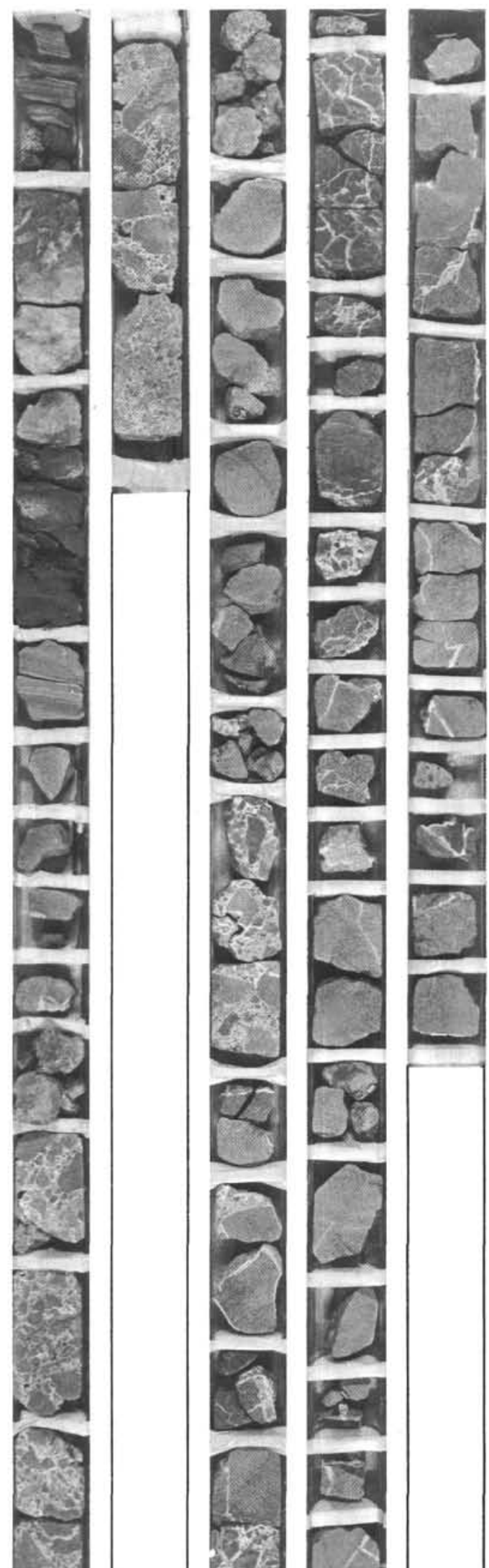


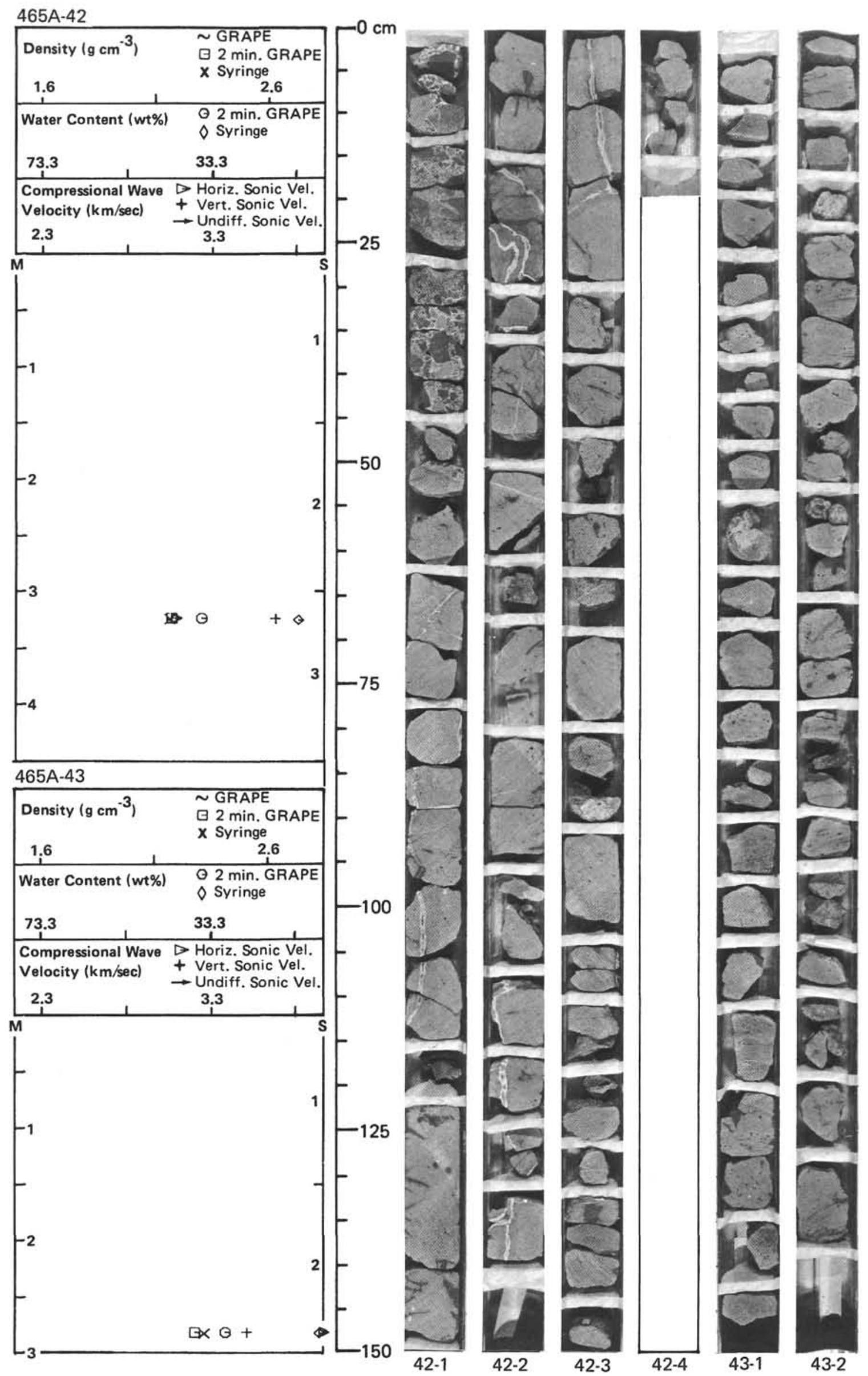




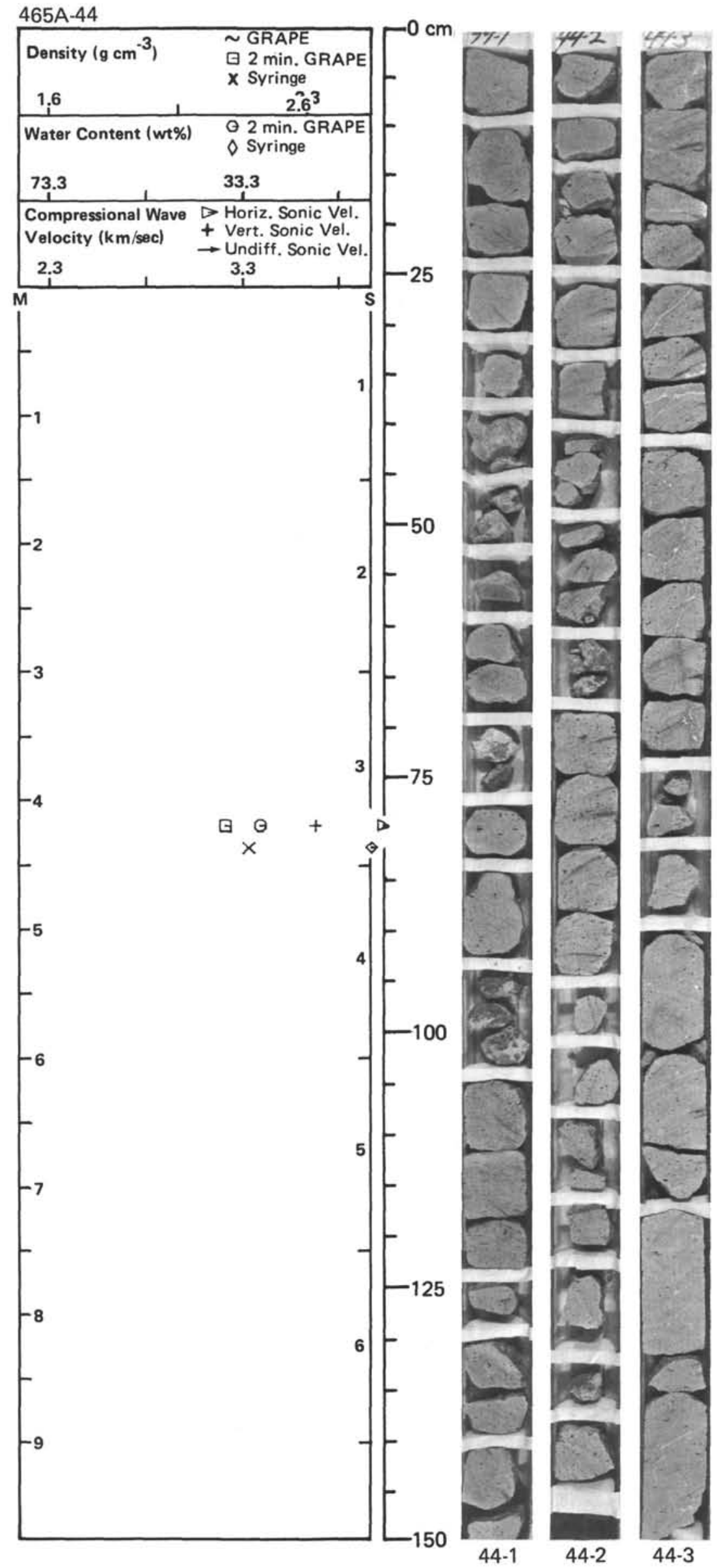




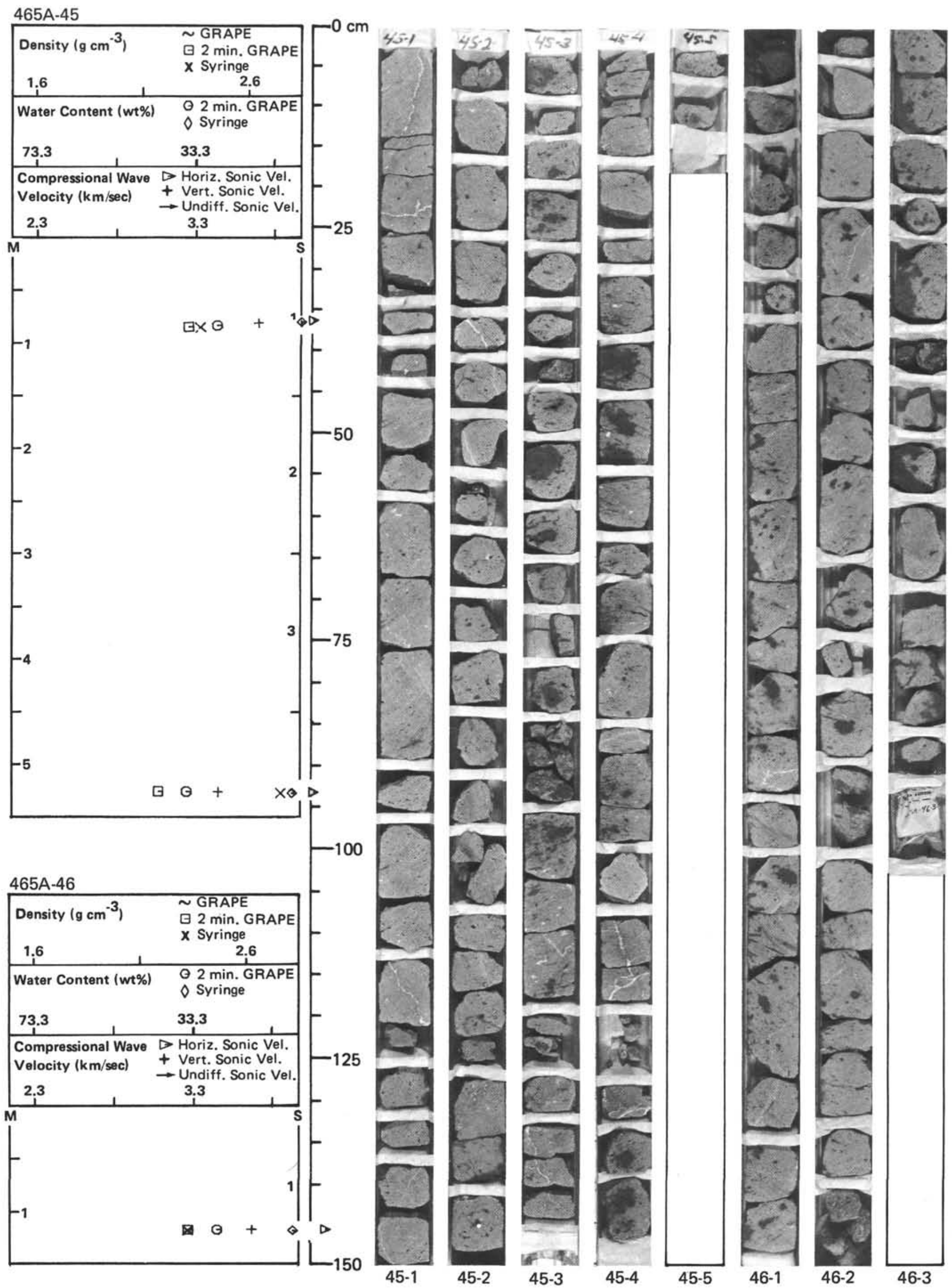

